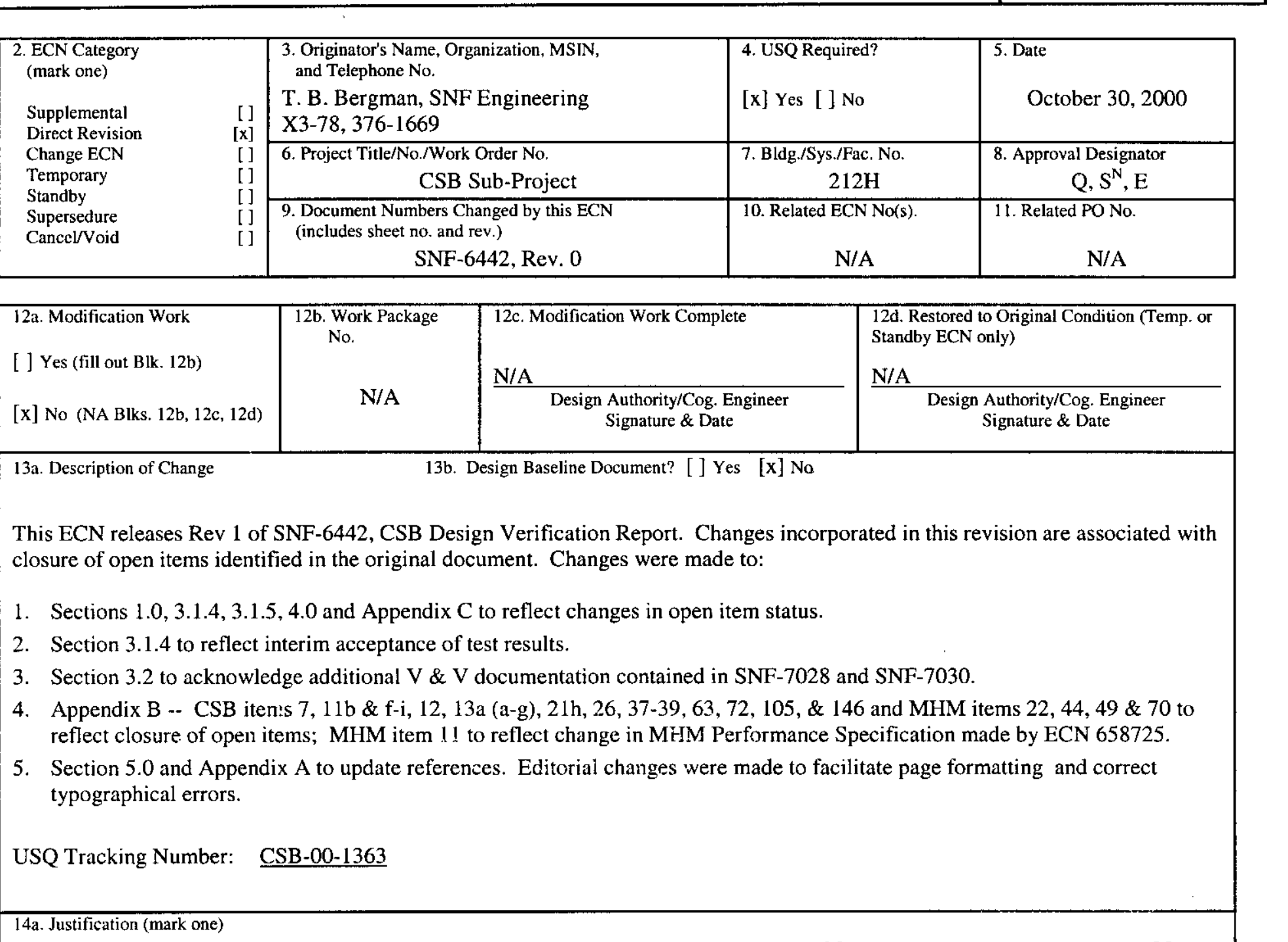

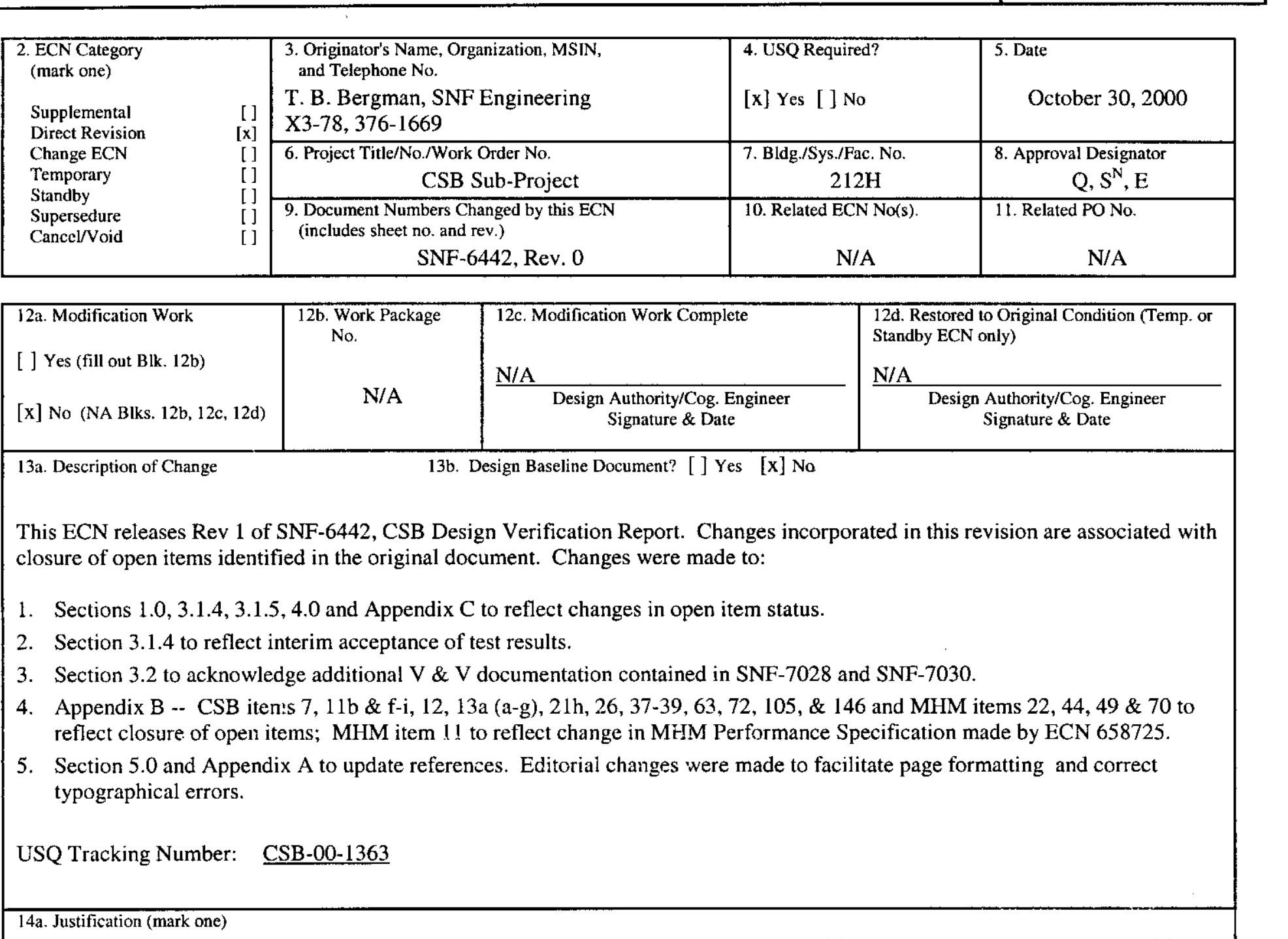

13a. Description of Change

13b. Design Baseline Document? [ ] Yes [x] No

This ECN releases Rev 1 of SNF-6442, CSB Design Verification Report. Changes incorporated in this revision are associated with closure of open items identified in the original document. Changes were made to:

1. Sections 1.0, 3.1.4, 3.1.5, 4.0 and Appendix $\mathrm{C}$ to reflect changes in open item status.

2. Section 3.1.4 to reflect interim acceptance of test results.

3. Section 3.2 to acknowledge additional V \& V documentation contained in SNF-7028 and SNF-7030.

4. Appendix B -- CSB iten:s 7, 11b \& f-i, 12, 13a (a-g), 21h, 26, 37-39, 63, 72, 105, \& 146 and MHM items 22, 44, 49 \& 70 to reflect closure of open items; MHM item 1! to reflect change in MHM Performance Specification made by ECN 658725.

5. Section 5.0 and Appendix A to update references. Editorial changes were made to facilitate page formatting and correct typographical errors.

USQ Tracking Number: $\quad$ CSB-00-1363

\begin{tabular}{|c|c|c|c|c|c|c|c|}
\hline Criteria Change & [ ] & Design Improvement & {$[\mathrm{x}]$} & Environmental & [ ] & Facility Deactivation & [ ] \\
\hline As-Found & [ ] & Facilitate Const & [ ] & Const. Error/Omission & [ ] & Design Error/Omission & [ ] \\
\hline
\end{tabular}

Revision required to reflect closure of open items and make editorial corrections.

Design Verification by independent review per AP EN-6-027

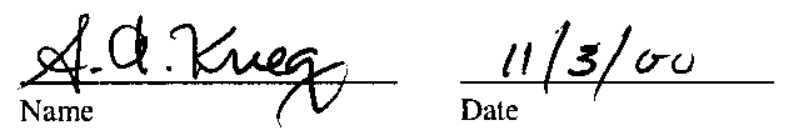

15. Distribution (include name, MSIN, and no. of copies)

See attached distribution coversheet. 


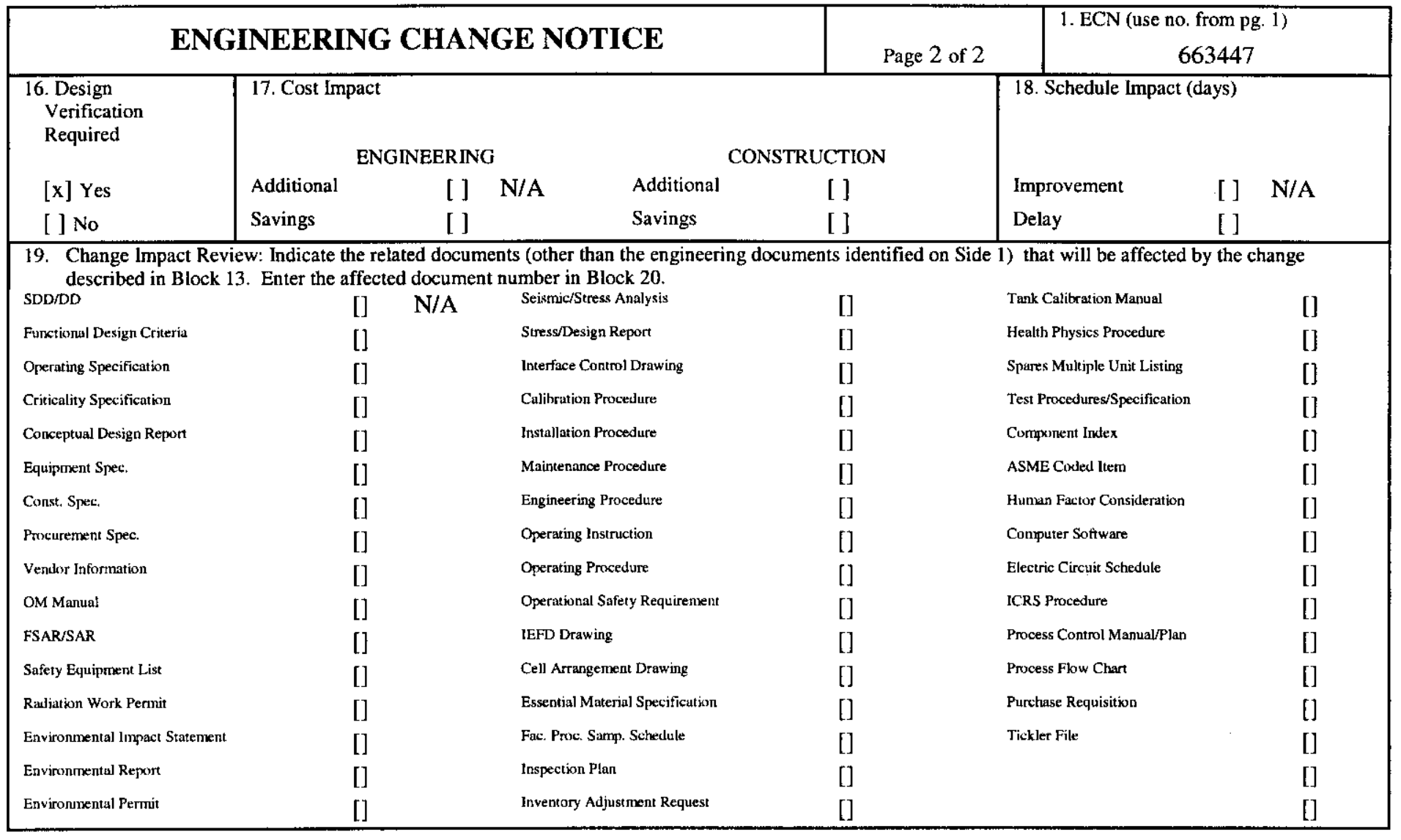

20. Other Affected Documents: (NOTE: Documents listed below will not be revised by this ECN.) Signatures below indicate that the signing organization has been notified of other affected documents listed below.

21. Approvals

Cog Eng N/A

$\operatorname{Cog} M g r$

G. D. Bazinet

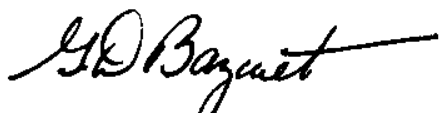

QA S.S. Moss

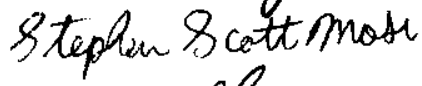

Safety L. J. Garvin

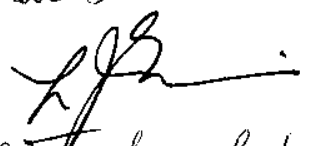

Environ

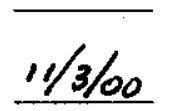

$10-3 i-2000$

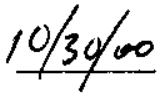

DEPARTMENT OF ENERGY

Signature or a Control Number that tracks the Approval Signature

N/A

$1 / 12 / 00$ ADDITIONAL 
DISTRIBUTION SHEET

\begin{tabular}{|c|c|c|c|c|c|}
\hline \multirow{2}{*}{$\begin{array}{l}\text { To } \\
\text { Distribution }\end{array}$} & \multirow{2}{*}{\multicolumn{3}{|c|}{$\begin{array}{l}\text { From } \\
\text { CSB Subproject }\end{array}$}} & \multicolumn{2}{|l|}{ Page 1 of 1} \\
\hline & & & & \multicolumn{2}{|l|}{ Date $11 / 03 / 00$} \\
\hline \multicolumn{4}{|l|}{ Project Title/Work Order } & \multicolumn{2}{|l|}{ EDT No N/A } \\
\hline \multicolumn{4}{|l|}{ SNF-6442, Rev. 1} & \multicolumn{2}{|c|}{ ECN No. 663447} \\
\hline \multicolumn{6}{|l|}{ Design Verification Report } \\
\hline \multicolumn{6}{|c|}{ Spent Nuclear Fuel Project Canister Storage Building } \\
\hline Name & MSIN & $\begin{array}{l}\text { Text } \\
\text { With All } \\
\text { Attach. }\end{array}$ & Text Only & $\begin{array}{l}\text { Attach./ } \\
\text { Appendix } \\
\text { Only }\end{array}$ & $\begin{array}{c}\text { EDT/ECN } \\
\text { Only }\end{array}$ \\
\hline
\end{tabular}

G. D. Bazinet

H R. B. Bendixsen

$\mathrm{H}$ T. B. Bergman

S8-06 $\mathrm{X}$

H E. Biebesheimer

S8-07 $X$

H L. J. Garvin

$\mathrm{X} 3-78 \quad \mathrm{X}$

H S. A. Krieg

S8-05 $X$

H S. S. Moss

S8-07 $X$

H C. E. Swenson

S8-05 $X$

H D. J. Watson

S8-07 $X$

H CSB Project Files

S8-07 $\mathrm{X}$

$\mathrm{H}$ Central Files

X3-79 $\mathrm{X}$

S8-05 $X$

B1-07 $\mathrm{X}$ 


\section{Design Verification Report Spent Nuclear Fuel Project Canister Storage Building}

Prepared for the U.S. Department of Energy

Assistant Secretary for Environmental Management

Project Hanford Management Contractor for the

U.S. Department of Energy under Contract D-AC06-96RL13200

\section{Fluor Hanford}

P.O. Box 1000

Richland, Washington 
SNF-6442

Revision 1

ECN-663447

\section{Design Verification Report Spent Nuclear Fuel Project Canister Storage Building}

Project No: W-379

Document Type: RPT

Division: SNF

G. D. Bazinet

NHC

Rev 0 prepared by:

W.W. Pickett

Vista Engineering \& Technology

Date Published

October 2000

\section{Fluor Hanford}

Prepared for the U.S. Department of Energy

Assistant Secretary for Environmental Management

Project Hanford Management Contractor for the

U.S. Department of Energy under Contract DE-AC06-96RL13200

P.O. Box 1000

Richland, Washington

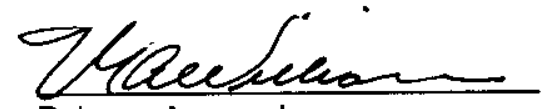

Release Approval

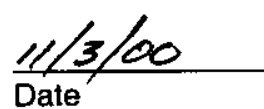

Date

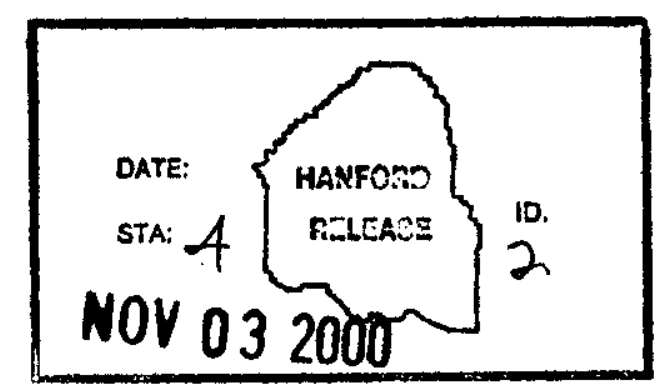

Release Stamp 
TRADEMARK DISCLAIMER

Reference herein to any specific commercial product, process, or service by trade name, trademark, manufacturer, or otherwise, does not necessarily constitute or imply its endorsement, recommendation, or favoring by the United States Government or any agency thereof or its contractors or subcontractors.

This report has been reproduced from the best available copy.

Printed in the United States of America

Total Pages: 142

SNF- $6442,2 \omega 1$ 


\section{RECORD OF REVISION}

(1) Document Number

SNF-6642, Rev. 1

Page 1

(2) Title

Design Verification Report - Spent Nuclear Fuel Project Canister Storage Building

CHANGE CONTROL RECORD

\begin{tabular}{|c|c|c|c|}
\hline \multirow[t]{2}{*}{ (3) Revision } & \multirow[t]{2}{*}{ (4) Description of Change - Replace, Add, and Delete Pages } & \multicolumn{2}{|c|}{ Authorized for Release } \\
\hline & & (5) Cog. Engr. & (6) Cog. Mgr. \\
\hline & (7) & & \\
\hline 0 & EDT-629819 & & \\
\hline 1 RS & 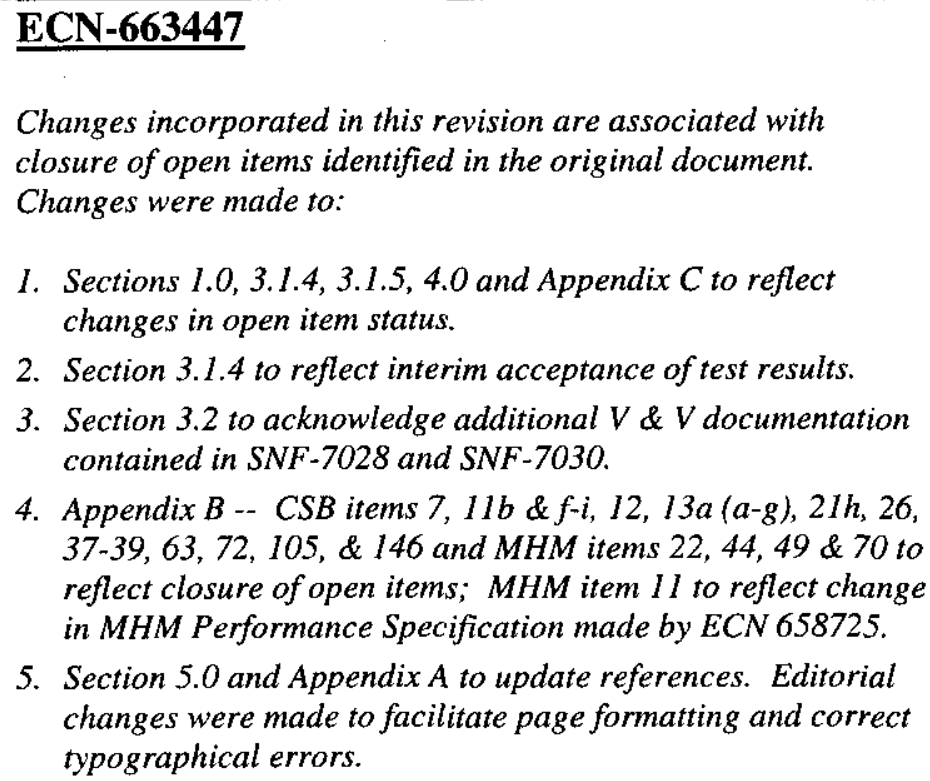 & & G. D. Bazinet \\
\hline & & & \\
\hline & & & \\
\hline & & & \\
\hline & & & \\
\hline & & & \\
\hline
\end{tabular}


TABLE OF CONTENTS

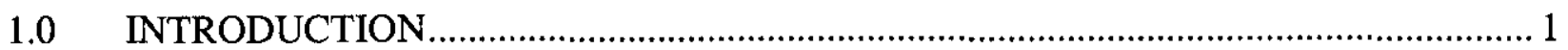

2.0 DESIGN VERIFICATION REQUIREMENTS .......................................................... 1

2.1 EVOLUTION OF DESIGN VERIFICATION PROCEDURAL DOCUMENTS AND REQUIREMENTS …………….........................................

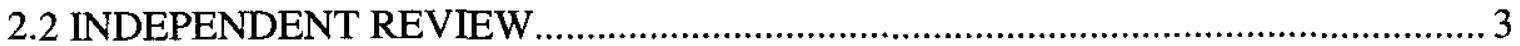

2.3 ALTERNATE CALCULATIONS ...................................................................... 3

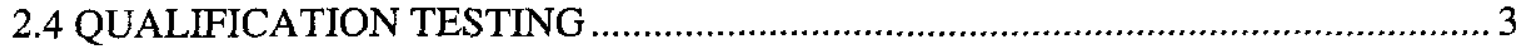

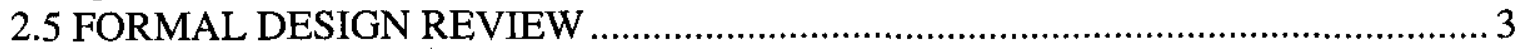

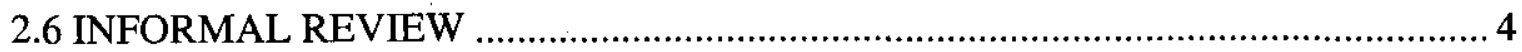

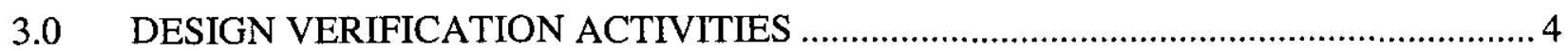

3.1 HISTORY OF DESIGN VERIFICATION ACTIVITIES ...................................... 8

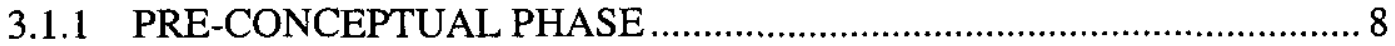

3.1.2 CONCEPTUAL PHASE................................................................... 8

3.1.3 PRELIMINARY AND DEFINITIVE DESIGN STAGE ........................ 9

3.1.4 CONSTRUCTION AND STARTUP PHASE ....................................... 15

3.1.5 DESIGN VERIFICATION ACTIVITIES TO BE COMPLETED ............ 18

3.2 EVIDENCE THAT DESIGN REQUIREMENTS ARE MET ……........................... 19

3.3 EVIDENCE THAT DESIGN VERIFICATION REQUIREMENTS ARE

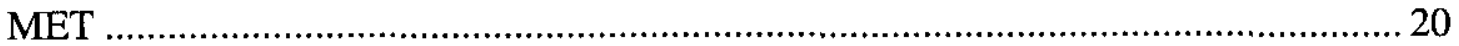

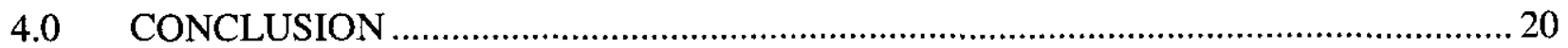

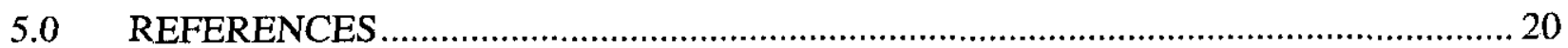

Appendix A: $\quad$ List of Project Design and Design Verification Documents

Appendix B: $\quad$ Design Requirement Compliance Matrix

Appendix C: $\quad$ Design Verification Status Questionnaire 


\section{SNF-6442 REV 1}

\section{FIGURES}

Figure 1. CSB Technical Baseline Development and Associated Verification Methods............ 6

Figure 2. Exhibit 8.0-1 Design Control Procedures Manual for CSB Engineering Control and Review Cycle

\section{TABLES}

Table 1. CSB Baseline Design Stage Criteria, Design Output, and Verification...................... 6 


\section{TERMS}

\begin{tabular}{|c|c|}
\hline $\mathrm{A} / \mathrm{E}$ & Architect/Engineer \\
\hline $\mathrm{ABU}$ & Acceptance for Beneficial Use \\
\hline $\mathrm{ACD}$ & Advanced Conceptual Design \\
\hline ANSI & American National Standards Institute \\
\hline ASME & American Society of Mechanical Engineers \\
\hline CAT & Construction Acceptance Test \\
\hline $\mathrm{CN}$ & Conference Notes \\
\hline CSB & Canister Storage Building \\
\hline DCPM & Design Control Procedures Manual \\
\hline DESH & Duke Engineering Services Hanford \\
\hline DOE & Department of Energy \\
\hline DOE/RL & Department of Energy, Richland \\
\hline $\mathrm{ECN}$ & Engineering Change Notice \\
\hline EDT & Engineering Data Transmittal \\
\hline FAT & Factory Acceptance Test \\
\hline FDC & Functional Design Criteria \\
\hline FDI & Fluor Daniel Incorporated \\
\hline FDR & Formal Design Review \\
\hline FMECA & Failure Mode Effect Critical Analysis \\
\hline FRD & Functions and Requirements Documents \\
\hline GEM & Gaseous Effluent Monitoring \\
\hline HWVP & Hanford Waste Vitrification Plant \\
\hline IDR & Independent Design Review \\
\hline IR & Independent Review \\
\hline JTG & Joint Test Group \\
\hline $\mathrm{MCO}$ & Multi-Canister Overpack \\
\hline MHM & MCO Handling Machine \\
\hline MM & Meeting Minutes \\
\hline NOG-1 & Nuclear Overhead Gantry ASME crane requirements \\
\hline OSHA & Occupational Safety and Health Administration \\
\hline PAT & Pre-Operational Acceptance Test \\
\hline RAM & Reliability, Availability, Maintainability analysis \\
\hline SNF & Spent Nuclear Fuel \\
\hline SSC & Structures, Systems and Components \\
\hline SSF & Staging and Storage Facility \\
\hline TDP & Technical Data Package \\
\hline TRB & Test Review Board \\
\hline VDT & Vendor Data Transmittal \\
\hline WHC & Westinghouse Hanford Company \\
\hline
\end{tabular}




\section{SNF-6442 REV 1}

This page intentionally left blank. 


\section{Design Verification Report Spent Nuclear Fuel-Canister Storage Building}

\subsection{INTRODUCTION}

The Sub-project W379, "Spent Nuclear Fuel Canister Storage Building (CSB)," was established as part of the Spent Nuclear Fuel (SNF) Project. The primary mission of the CSB is to safely store spent nuclear fuel removed from the K Basins in dry storage until such time that it can be transferred to the national geological repository at Yucca Mountain Nevada.

This sub-project was initiated in late 1994 by a series of studies and conceptual designs. These studies determined that the partially constructed storage building, originally built as part of the Hanford Waste Vitrification Plant (HWVP) Project, could be redesigned to safely store the spent nuclear fuel.

The scope of the CSB facility initially included a receiving station, a hot conditioning system, a storage vault, and a Multi-Canister Overpack (MCO) Handling Machine (MHM). Because of evolution of the project technical strategy, the hot conditioning system was deleted from the scope and MCO welding and sampling stations were added in its place. This report outlines the methods, procedures, and outputs developed by Project W379 to verify that the provided Structures, Systems, and Components (SSCs): satisfy the design requirements and acceptance criteria; perform their intended function; ensure that failure modes and hazards have been addressed in the design; and ensure that the SSCs as installed will not adversely impact other SSCs.

The original version of this document was prepared by Vista Engineering for the SNF Project. The purpose of this revision is to document completion of verification actions that were pending at the time the initial report was prepared. Verification activities for the installed and operational SSCs have been completed. Verification of future additions to the CSB related to the canister cover cap and welding fixture system and MCO Internal Gas Sampling equipment will be completed as appropriate for those components. The open items related to verification of those requirements are noted in section 3.1.5 and will be tracked as part of the CSB Facility action tracking system.

\subsection{DESIGN VERIFICATION REQUIREMENTS}

\subsection{EVOLUTION OF DESIGN VERIFICATION PROCEDURAL DOCUMENTS AND REQUIREMENTS}

When Sub-project W379 was initiated, design verification was defined for the CSB sub-project by Westinghouse Hanford Company (WHC) procedure [WHC-CM-6.1], Standard Engineering Practices, EP 4.1, "Design Verification", and on the SNF Project by [HNF-1613], "Spent Nuclear Fuel Engineering Practices". Currently, design verification on the Hanford Site must be conducted in 


\section{SNF-6442 REV 1}

accordance with [HNF-PRO-1819], "Engineering Requirements". The SNF project has developed Administrative Procedure [AP-EN-6-027-01], "Design Verification Process", for implementation of the [HNF-PRO-1819] verification requirements.

Even with the changes in the forms of the design verification implementing procedures, the design verification requirements themselves have not evolved extensively. The primary changes, which have been implemented in most recent design verification procedures, are mainly on the following aspects:

- More formalization of planning actions:

- Ensure the graded approach on verification methods selection is based on a risk analysis (a methodology is provided as guidance)

- Ensure that verification activities are defined during the planning phase, including:

- Acceptance criteria

- Verification responsibilities of the Architect/Engineer (A/E)

- Verification documentation requirements

- Ensure verification activities are integrated in activity/cost/schedule baselines

- Implementation of a method to control verification status

- The addition of some detailed requirements (e.g. Design Verification Questionnaire).

The core verification requirements remain the same, and verification, regardless of originating procedures, can be categorized under the principle methods of design verification as defined in [APEN-6-027-01]. Verification methods include: Independent Review, Alternate Calculations, Qualification Testing, Formal Design Review, and Informal Review. The aspects of verification can be summarized as follows:

- Identify Design Requirements and associated verification methods.

- Plan and prepare verification activities and integrate them into project tasks.

- Perform verification activities according to selected method.

- Implement corrective actions resulting from verification, to ensure requirements are met and tracked to closure.

- Document verification activities and demonstrate design requirements are met.

The different design verification methods listed above are applied on a graded approach based on the importance to safety and the environment, complexity of the design, degree of standardization, state of the art, similarity with proven designs, and programmatic impacts. General application of the 


\section{SNF-6442 REV 1}

different design verification methods used by the CSB is described in sections 2.2 through 2.6. Specific details and documentation of design verification is described in section 3 .

\subsection{INDEPENDENT REVIEW}

Independent reviews were used extensively to verify the design packages and procurement packages produced by the design agent, Fluor Daniel Incorporated (FDI). The independent reviews performed on FDI Design met all the requirements of a formal review with the exception of the identification of a chairman and the issuance of a design review completion report. Independent reviews were conducted in accordance with FDI's Design Control Procedures Manual (DCPM) and documented in conference notes issued with PHMC concurrence. An independent review was also completed on the MCO design. FDI used independent design review on calculations applying to SSCs with enhanced quality assurance requirements, and the computer codes were independently validated and verified.

\subsection{ALTERNATE CALCULATIONS}

Design verification by means of alternate calculations involves the use of one or more different methods of analysis to check and ensure the correctness and applicability of pertinent design calculations, including both hand and computer calculations. Some of the alternate calculations include the following:

- An alternate calculation was performed by Q Metrics of the thermal analysis of the MCO loading during CSB Start-up.

- An alternate calculation of the CSB Design Capacity.

- An Independent Analysis of MCO Critical Failures by M\&D Associates.

- Validation and Verification of computer codes used for Spent Nuclear Fuel CSB.

\subsection{QUALIFICATION TESTING}

Qualification testing was applied as a final verification for all testable systems and SSCs supplied by the project to verify they met the requirements and that the systems functioned as intended. Qualification testing includes a combination of:

- Factory acceptance testing to confirm that components meet procurement specification requirements,

- Construction acceptance tests, to confirm that components are installed in accordance with the construction specification requirements, and

- Pre-operational acceptance tests to assure that all SSC's function as intended as an integrated system.

\subsection{FORMAL DESIGN REVIEW}

Formal design reviews are typically conducted at key stages of the design process to provide a comprehensive verification that the design meets requirements. The bulk of CSB design reviews that 
serve this function are classified as independent reviews as described in section 2.2. Formal Design reviews on Project W379 that were completed, include:

- The Conceptual Design Report

- The MHM System

- The Security System

- The Sample/Weld Station System

\subsection{INFORMAL REVIEW}

This method was used for review of non-final design documents, such as engineering studies, Functions and Requirements Documents (FRD), Performance Specifications, and for reviews of designs verified by others (e.g. design change notices). This method [AP-EN-6-027-01] was used extensively and is documented by signature on the releasing document such as the EDT or ECN. Design verification documentation included with the EDT or recorded on the EDT or ECN is transmitted to a Document Control Release Station for processing and retention.

\subsection{DESIGN VERIFICATION ACTIVITIES}

This section briefly describes the history of the W379 Sub-project and the design as well as design verification activities. The CSB requirements baseline at each project stage, the engineering products and the verification methods used are contained in Table 1. A schedule of events with the technical baseline development and associated verification methods are shown in Figure 1. The pre-conceptual and conceptual phases of the project were verified by both informal review and formal design review. The approval and release signatures of the reviews on the Engineering Data Transmittal (EDT) coversheets document the informal reviews. The conceptual design underwent a formal design review.

During the preliminary and detailed design stages, the Design Agent (Fluor Daniel Incorporated) developed the Design Control Procedures Manual (DCPM) that was used for directing design control and design verification activities. The DCPM has requirements for verification by checking, independent design review, squad checks, internal reviews, and client reviews. Additionally there was independent analysis performed and/or directed by the Project Management Hanford Contractor (PHMC).

Verification in the construction/start-up phase included: analysis, informal review, independent review, factory acceptance testing, construction acceptance testing, inspections, pre-operational testing, and Asbuilts. Changes to the approved design are controlled by Design Change Notice (DCN) process as outlined in the DCPM. SNF Procedure [AP-EN-6-027-01] states that all design changes are required to undergo a design verification. The design verification included an evaluation of the effects of those changes on the overall design and on any design analyses upon which the design change is based that are affected by the change. These reviews were included as assurance that the design analyses for the structure, system, or components are still valid. For the CSB, verification of changes was implemented with independent reviews as documented by the signatures on the DCNs, including the Design Authority. 
A list of the design documentation and design verification documents that were created during the different phases of the project has been developed and is included in Appendix A " List of Project Design and Design Verification Documents." A current list of drawings, and specifications is contained in the Acceptance for Beneficial Use (ABU) checklist [SNF-6253]. 
Table 1. CSB Baseline Design Stage Criteria, Design Output, and Verification

\begin{tabular}{|c|c|c|c|}
\hline Design Stage & Criteria & Design Output & Verification Reference \\
\hline \multirow[t]{3}{*}{$\begin{array}{l}\text { Pre-Conceptual } \\
\text { Design \& } \\
\text { Conceptual } \\
\text { Design }\end{array}$} & \multirow[t]{3}{*}{$\begin{array}{l}\text { SNF Project CSB, Functions } \\
\text { and Requirements } \\
\text { INF-SD-SNF-FRD-010 }\end{array}$} & $\begin{array}{l}\text { Staging and Storage Facility } \\
\text { Feasibility Study Final } \\
\text { Report } \\
\text { WHC-SD-W379-ES-002 }\end{array}$ & $\begin{array}{l}\text { Informal Review documented } \\
\text { by EDT signoff }\end{array}$ \\
\hline & & $\begin{array}{l}\text { CSB T'rade Study Final } \\
\text { Report } \\
\text { WHC-SD-W379-ES-003 }\end{array}$ & $\begin{array}{l}\text { Intormal Review documented } \\
\text { by EDT }\end{array}$ \\
\hline & & $\begin{array}{l}\text { Spent Nuclear Fuel Canister } \\
\text { Storage Building Conceptual } \\
\text { Design Report } \\
\text { WHC-SD-W379-CDR-001 }\end{array}$ & $\begin{array}{l}\text { Formal Review: } \\
\text { SNF CSB Conceptual Design } \\
\text { Report Review Committee } \\
\text { Report } \\
\text { WHC-SD-W379-DR-001 }\end{array}$ \\
\hline \multirow[t]{3}{*}{$\begin{array}{l}\text { Preliminary \& } \\
\text { Definitive Design } \\
\text { Stage }\end{array}$} & \multirow{3}{*}{$\begin{array}{l}\text { Performance Specification for } \\
\text { the Spent Nuclear Fuel Canister } \\
\text { Storage Building } \\
\text { HNF-S-0425 } \\
\text { Specification for the MCO } \\
\text { Handling Machine } \\
\text { IINF-S-0468 }\end{array}$} & $\begin{array}{l}\text { CSB Facility Drawings } \\
\text { Procurement Specifications }\end{array}$ & $\begin{array}{l}\text { Design Package Reviews: } \\
\text { See Table } 2\end{array}$ \\
\hline & & Calculations & $\begin{array}{l}\text { PIDl Files containing } \\
\text { Independent Design Reviews }\end{array}$ \\
\hline & & $\begin{array}{l}\text { MHM Design } \\
\text { Vender File V1-50100 }\end{array}$ & $\begin{array}{l}\text { Formal Review: } \\
\text { MliM 100\%: Design Package } \\
\text { in vendor file \#VI-50100 and } \\
\text { letlers: } \\
\text { MHIM-BTR-092-R.1, } \\
\text { DHSH-9761988.1; } \\
\text { MHM-BTR-101, } \\
\text { DESH-9860199; and } \\
\text { MHIM-13TR-111, } \\
\text { DIESII-9851598. }\end{array}$ \\
\hline \multirow[t]{4}{*}{$\begin{array}{l}\text { Design \& } \\
\text { Construction } \\
\text { Phases }\end{array}$} & \multirow{3}{*}{$\begin{array}{l}\text { Performance Specification for } \\
\text { the Spent Nuclear Fuel Canister } \\
\text { Storage Building } \\
\text { HNF-S-0425 } \\
\text { Specilication for the MCO } \\
\text { Handling Machine } \\
\text { HNF-S-0468 }\end{array}$} & $\begin{array}{l}\text { Design Change Notices } \\
\text { (I)CN) and As-builts }\end{array}$ & $\begin{array}{l}\text { Informal Review documented } \\
\text { by } 1 \mathrm{CN} \\
\text { signoli }\end{array}$ \\
\hline & & $\begin{array}{l}\text { Procurement Specitications } \\
\text { Construction Specifications }\end{array}$ & $\begin{array}{l}\text { Independent Review } \\
\text { Specifications: } \\
\text { Sec Table } 2\end{array}$ \\
\hline & & Safety Documentation & Independent Review (EDT) \\
\hline & $\begin{array}{l}\text { CSB System 'Test } \\
\text { Specifications: } \\
\text { SNI-W379-TS-001 - SNI- } \\
\text { W379-TS-025-I }\end{array}$ & Testing Documentation & $\begin{array}{l}\text { Independent Reviews of Test } \\
\text { Specifications, Pre- } \\
\text { operational Test Procedures, } \\
\text { and Test Summary Reports: } \\
\text { See Appendix A }\end{array}$ \\
\hline
\end{tabular}




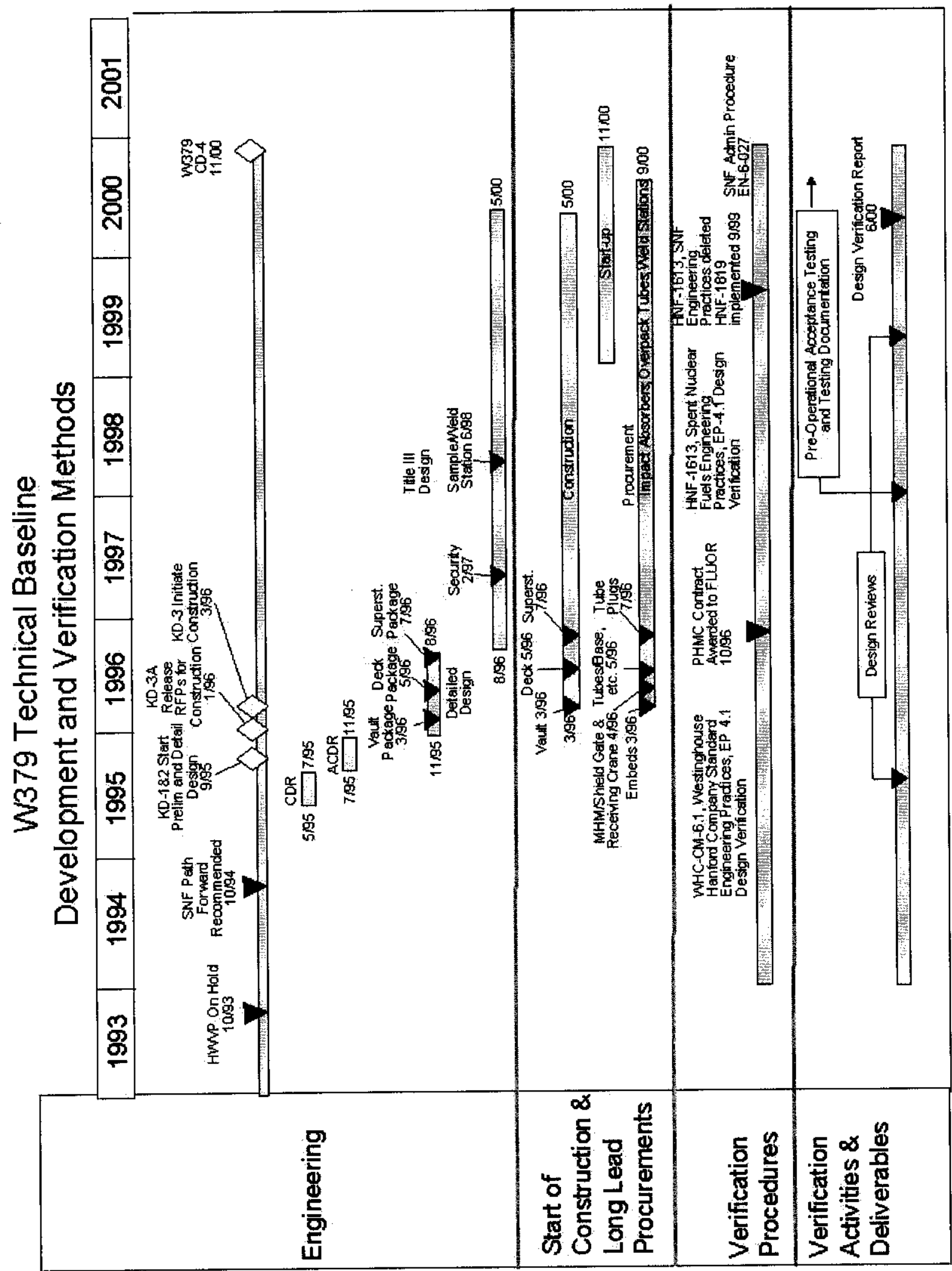




\subsection{HISTORY OF DESIGN VERIFICATION ACTIVITIES}

\subsubsection{PRE-CONCEPTUAL PHASE}

In October 1994, WHC published the Hanford Spent Nuclear Fuel Project Recommended Path Forward, WHC-EP-0830, outlining a recommended approach for expedited removal of spent fuel from the K Basins. An essential part of this recommended approach was the use of a new facility to safely store the spent nuclear fuel.

The entire pre-conceptual phase was conducted under the direct responsibility of the DOE prime contractor (WHC) with many of the feasibility studies subcontracted to an A/E (ICF Kaiser/FDI). In order to support an evaluation of adapting the HWVP storage facility for use with the SNF project, WHC initiated a Staging and Storage Facility (SSF) Feasibility Study, WHC-SD-W379-ES-002, with Fluor Daniel Incorporated (FDI) in January 1995, and a CSB Trade Study, WHC-SD-W379-ES-003, was performed in May 1995. HNF-SD-SNF-FRD-010, SNF Project CSB Functions and Requirements, documented the upper level functions and requirements in June 1995. Verification activities in this phase consisted of informal reviews of the documents produced during this design stage. The signatures of the reviewers, including Safety, Quality Assurance, the Design Authority, etc. on the Engineering Data Transmittals (EDTs) document the design verification.

The mission for Project W379 was accepted by DOE-RL in DOE-RL letter [95-NMD-081DOE-RL], K Basins Path Forward Approval of Mission Need.

\subsubsection{CONCEPTUAL PHASE}

The conceptual design was started in May 1995 concurrent with a CSB trade study, WHC-SD-W379ES-003, that was intended to determine the most suitable site to store the K-Basin Spent Fuel. The CDR, "Spent Nuclear Fuel Canister Storage Building Conceptual Design Report," WHC-SD-W379CDR-001, was issued July 24, 1995. This CDR provided the technical basis for the initial project cost baseline. The CDR underwent a formal design review and a design review report of the CDR, WHCSD-W379-DR-001, was issued in September 1995.

The HWVP FDC and the Technical Data Package (TDP) were the source of design requirements during the conceptual design as a CSB Performance Specification was being developed. The CDR in conjunction with the "Hanford SNF Project Recommended Path Forward," WHC-EP-0830, provided the basis for proceeding with the Advanced Conceptual Design (ACD) in August 1995. A final version of the Performance Specification, WHC-S-0425, Rev. 0, was used during the ACD stage. The performance specification underwent an informal review as documented on EDT \#613003. The information developed during the Advanced Conceptual Design was rolled directly into the detailed design when capital funding was received in late 1995. A revised estimate based on the ACD effort was documented in FDI correspondence FRF-2717 dated October 9, 1995. 


\subsubsection{PRELIMINARY AND DEFINITIVE DESIGN STAGE}

Detailed design efforts for the SNF CSB were initiated after capital funding was received at the end on November 1995. It was determined that phased releases of design media would support the aggressive construction schedule while allowing for the required design reviews. The facility was divided into three main packages and several smaller packages for design reviews and releases for construction. The three primary packages making up the CSB are the Vault, the Deck, and the Superstructure. The Vault package was issued on March 21, 1996, the Deck package was issued on May 10, 1996, and the Superstructure package was issued on July 26, 1996. A Detailed Design report was issued in August 1996 (FRP-061) to document the detailed design phase of the CSB. It contained the project background; the facility and engineering descriptions from each design discipline; a cost estimate; a schedule; the Design Basis Document; the system design description; the list of calculations; the list of design documents; and equipment, piping, and valve lists.

As verification that the design met the requirements, the DCPM required FDI to complete a design requirement compliance matrix. The first matrix was completed in April 1996 for baseline verification of the vault design against Performance specification WHC-S-0425 (Interoffice Correspondence, File 106 dated 4/12/96). The Compliance matrix was revised in July 1996 for the entire Canister Storage Building (FRT-2694).

Design verification requirements were met during detailed design by following the process outlined in the DCPM. Verification included interim design reviews, group reviews, squad checks, and client reviews/independent design reviews. Figure 2. contains Exhibit 8.0-1 of the DCPM, which diagrams the design, and design verification process that includes independent reviews by the PHMC. These reviews are documented in the FDI Conference Notes (CNs) listed in Table 2. The checking and design verification outlined in the DCPM and followed during the project are as follows:

- Interim Design Review - evaluates design concepts to assure that the design criteria and operational, maintenance, safety, and constructability objectives are met. The interim review is performed with participants from DOE, DESH, Construction Management, and Fluor Daniel.

- Group Review - an internal process that supports records of working documents that are maintained by the originating discipline.

- Squad Check - process used to perform technical design reviews of drawings and specifications in order to assure the adequacy of design and that necessary design requirements for interfacing disciplines have been clearly specified. Design documents are squad checked prior to release as approved for construction.

- Independent Design Review (Client Review) - includes a graded quality assurance program that is used to ensure the quality and adequacy of design drawings, specifications, and other detailed design services to be furnished by Fluor Daniel. The reviewer may be from the same company/organization, but was not involved as a participant, supervisor, technical reviewer or advisor in the work being reviewed and to the extent practical has freedom to do an impartial review. The independent reviews of the design packages are as outlined in Table 2. These independent reviews include a list of the PHMC reviewers. These reviews are documented in FDI Conference Notes (CNs). 
Figure 2. Exhibit 8.0-1 Design Control Procedures Manual for CSB Engineering Control and Review Cycle
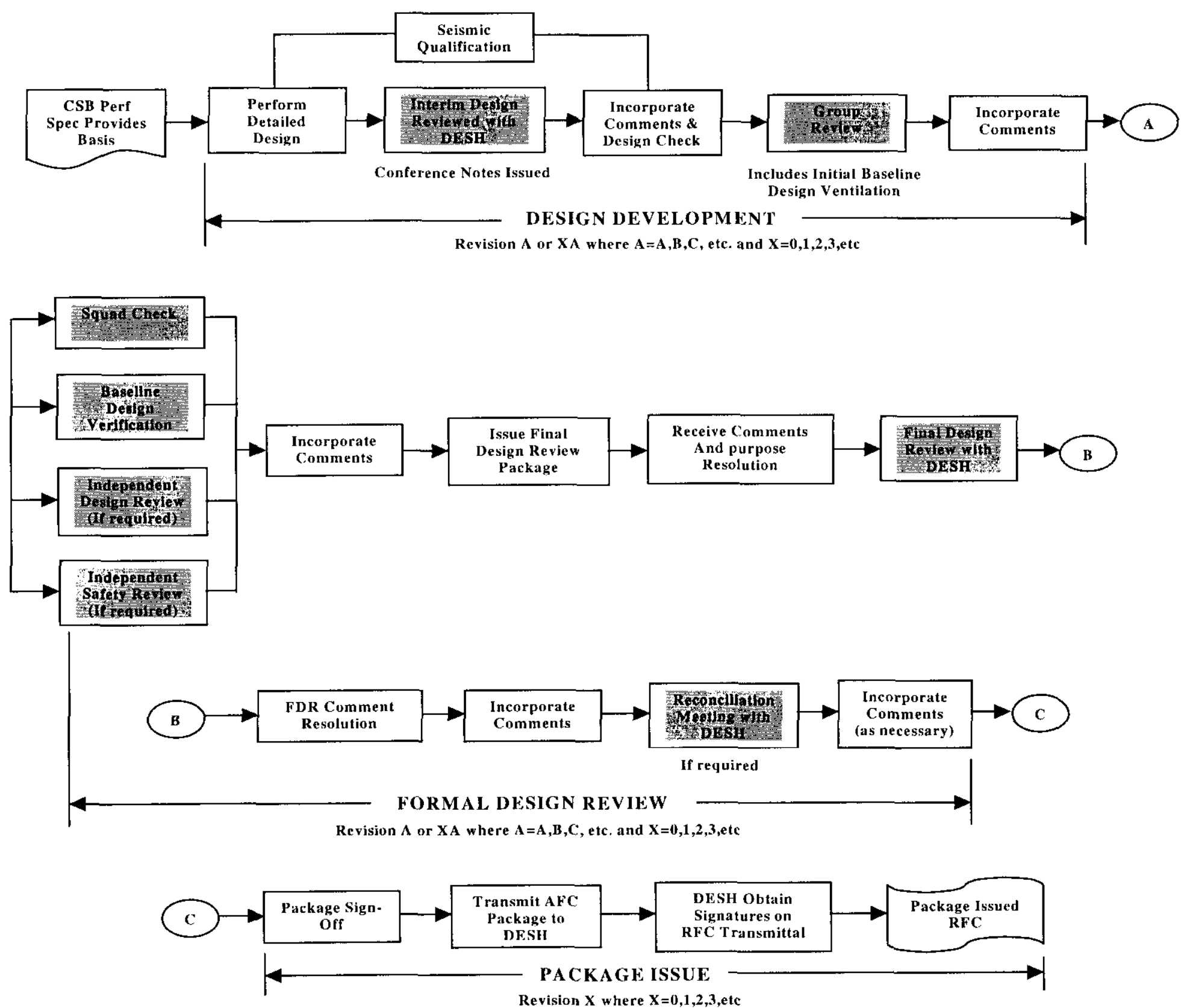
Table 2. Design Package Independent Reviews

\begin{tabular}{|c|c|c|c|}
\hline $\begin{array}{l}\text { Design/Procurement } \\
\text { Packages }\end{array}$ & Systems in Package & $\begin{array}{l}\text { Design Review } \\
\text { Comments }\end{array}$ & $\begin{array}{l}\text { Design Review } \\
\text { Completion Record }\end{array}$ \\
\hline Embed Package & Vault Embeds & 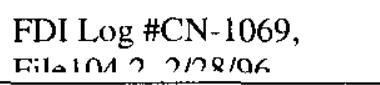 & $\begin{array}{l}\text { FDI Log \#CN-1071, } \\
\text { Fila1nM 2/1/06 }\end{array}$ \\
\hline CSB Vault Package & $\begin{array}{l}\text { Vault Structure, Rebar, } \\
\text { Concrete, etc. }\end{array}$ & $\begin{array}{l}\text { FDI Log \#CN-1078, File } \\
104.2,3 / 20 / 96\end{array}$ & $\begin{array}{l}\text { FDI Log \#CN-1079, } \\
\text { File 104.2, 3/21/96 } \\
\text { CN-1 123 (Seismic) }\end{array}$ \\
\hline MHM Shield Gate* & $\begin{array}{l}\text { Portable shield gate between } \\
\text { MHM and Deck }\end{array}$ & $\begin{array}{l}\text { FDI Log \#CN-1082, } \\
\text { File } 104.2,4 / 4 / 96\end{array}$ & $\begin{array}{l}\text { FDI Log \#CN-1084, } \\
\text { File } 104.2,4 / 4 / 96\end{array}$ \\
\hline CSB Receiving Crane & Receiving Crane & $\begin{array}{l}\text { FDI Log \#CN-1083, File } \\
104.2,4 / 04 / 96\end{array}$ & $\begin{array}{l}\text { FDI Log \#CN-1085, File } \\
104.2,4 / 04 / 96\end{array}$ \\
\hline CSB Deck Package & Deck, Rebar, Concrete, etc. & $\begin{array}{l}\text { FDI Log \#CN-1092, } \\
\text { File } 104.2,5 / 6 / 96\end{array}$ & $\begin{array}{l}\text { FDI Log \#CN-1094, } \\
\text { File } 104.2,5 / 9 / 96 \\
\text { CN-1123 (Seismic) }\end{array}$ \\
\hline $\begin{array}{l}\text { CSB Tubes, Base, Covers, } \\
\text { Absorbers, Cart Package }\end{array}$ & $\begin{array}{l}\text { MCO storage tubes, tube } \\
\text { bases, tube covers, Impact } \\
\text { absorbers, etc. }\end{array}$ & $\begin{array}{l}\text { FDI Log\#CN-1096, File } \\
104.2,5 / 28 / 96\end{array}$ & $\begin{array}{l}\text { FDI Log \# CN-1098, File } \\
104.2,5 / 31 / 96\end{array}$ \\
\hline CSB Superstructure Package & $\begin{array}{l}\text { HVAC, instrument air and } \\
\text { compressed air systems, } \\
\text { HEPA room, distribution } \\
\text { control room, change out room } \\
\text { roofing, siding, fire protection } \\
\text { systems, lighting, } \\
\text { communication/PAX system, } \\
\text { helium supply system, } \\
\text { electrical distribution system, } \\
\text { UPS system and battery room, } \\
\text { control room. }\end{array}$ & $\begin{array}{l}\text { FDI Log\#CN-1109, File } \\
104.2,7 / 25 / 96\end{array}$ & $\begin{array}{l}\text { FDI Log \#CN-1 11 } 10 \text {, File } \\
104.2,7 / 26 / 96\end{array}$ \\
\hline Tube Plug Package & Storage Tube Plugs & $\begin{array}{l}\text { FDI Log \#CN-1111 and } \\
1099, \text { File } 104.2, \\
7 / 29 / 96 \text { and } 6 / 10 / 96\end{array}$ & $\begin{array}{l}\text { FDI Log \#CN-11 12, File } \\
104.2,7 / 30 / 96\end{array}$ \\
\hline CSB/HCSA Design* & Hot Conditioning System & $\begin{array}{l}\text { FDI Log \#CN-1127, } \\
\text { File } 104.2,10 / 14 / 96\end{array}$ & $\begin{array}{l}\text { FDI Log \#CN-1128, } \\
\text { File 104.2, 10/17/96 }\end{array}$ \\
\hline $\begin{array}{l}\text { Security and Safeguards } \\
\text { Package }\end{array}$ & Security Systems & $\begin{array}{l}\text { FDI Log \#CN-1134 File } \\
104.2,2 / 28 / 97\end{array}$ & $\begin{array}{l}\text { FDI Log \#CN-1 } 136 \text { File } \\
104.2,2 / 28 / 97, \text { and } \\
\text { Formal Design Review } \\
\text { documented in Letter } \\
\text { FDH-9655540 R1 }\end{array}$ \\
\hline P\&IDS & P\&ID & $\begin{array}{l}\text { FDI Log \#CN-1150 File } \\
104.2,8 / 8 / 97\end{array}$ & $\begin{array}{l}\text { FDI Log \#CN-1150 File } \\
104.2,8 / 8 / 97\end{array}$ \\
\hline Canister Impact Absorber & $\begin{array}{l}\text { Impact Absorbers for Inside } \\
\text { Tubes }\end{array}$ & $\begin{array}{l}\text { FDI Log \#CN- } 1196 \text { File } \\
104.2,9 / 2 / 98\end{array}$ & $\begin{array}{l}\text { FDI Log \#CN-1196 File } \\
104.2,9 / 2 / 98\end{array}$ \\
\hline
\end{tabular}




\begin{tabular}{|c|c|c|c|}
\hline $\begin{array}{l}\text { Design/Procurement } \\
\text { Packages }\end{array}$ & Systems in Package & $\begin{array}{l}\text { Design Review } \\
\text { Comments }\end{array}$ & $\begin{array}{l}\text { Design Review } \\
\text { Completion Record }\end{array}$ \\
\hline MCO Sampling Station & MCO Sampling System & $\begin{array}{l}\text { FDI Log \#CN-1188 \& } \\
\text { 1189, File 104.2, } \\
\text { 110mo o mano }\end{array}$ & $\begin{array}{l}\text { FDI Log \#CN-1 } 190 \text { File } \\
104.2,6 / 29 / 98\end{array}$ \\
\hline HEPA Filter & $\begin{array}{l}\text { Exhaust Fan and HEPAs for } \\
\text { Sample Weld Station }\end{array}$ & $\begin{array}{l}\text { FD1 Log \#CN-1 } 199 \text { File } \\
104.2,9 / 23 / 98\end{array}$ & $\begin{array}{l}\text { FDI Log \#CN-1 } 199 \text { File } \\
104.2,9 / 23 / 98\end{array}$ \\
\hline Weld Station & $\begin{array}{l}\text { MCO Cover Cap Welding } \\
\text { System }\end{array}$ & $\begin{array}{l}\text { FDI Log \#CN-1212 File } \\
104.2,1 / 14 / 99\end{array}$ & $\begin{array}{l}\text { SNF MCO Design } \\
\text { Review Completion } \\
\text { Report, SNF-5222 }\end{array}$ \\
\hline $\begin{array}{l}\text { Overpack Storage Tube and } \\
\text { Plugs }\end{array}$ & $\begin{array}{l}\text { Overpack Storage tubes and } \\
\text { Plugs }\end{array}$ & $\begin{array}{l}\text { FDI Log \#CN-1225 File } \\
104.2,3 / 02 / 99\end{array}$ & $\begin{array}{l}\text { FDI Log \#CN-1232 File } \\
104.2,4 / 29 / 99\end{array}$ \\
\hline Tube Plug Adapter & $\begin{array}{l}\text { Tube Plug Adapter for MHM } \\
\text { Grapple }\end{array}$ & $\begin{array}{l}\text { FDI Log \#CN-1233 File } \\
104.2,5 / 13 / 99\end{array}$ & $\begin{array}{l}\text { FDI Log \#CN-1234 File } \\
104.2,5 / 20 / 99\end{array}$ \\
\hline $\begin{array}{l}\text { Transfer System Impact } \\
\text { absorber* }\end{array}$ & $\begin{array}{l}\text { Impact Absorber for use } \\
\text { During MCO Off-Load }\end{array}$ & $\begin{array}{l}\text { FDI Log \#CN-1335 File } \\
104.2,5 / 21 / 99\end{array}$ & $-\mathrm{N} / \mathrm{A}$ \\
\hline High security gate & CSB Building Gate & $\begin{array}{l}\text { FDI Log \#CN-1236 File } \\
104.2,6 / 17 / 99\end{array}$ & - \\
\hline Rolling Gate & CSB Building Gate & $\begin{array}{l}\text { FDI Log \#CN-1243 File } \\
104.2,7 / 12 / 99\end{array}$ & - \\
\hline Guide Ring Funnel* & $\begin{array}{l}\text { Alignment Funnel/Interface } \\
\text { for Storage Tube }\end{array}$ & $\begin{array}{l}\text { FDI Log \#CN-1247 File } \\
104.2,7 / 19 / 99\end{array}$ & $-N / A$ \\
\hline CSB Operations Building & Operations Personnel Trailers & $\begin{array}{l}\text { FDI Log \#CN-1238 File } \\
104.2,6 / 28 / 99\end{array}$ & - \\
\hline Frog Tooling Design package & Tool for Handling Rail Frogs & $\begin{array}{l}\text { FDI Log \#CN-1250 File } \\
104.2,9 / 7 / 99\end{array}$ & - \\
\hline Shield hatch & $\begin{array}{l}\text { Shield Covers for Cask } \\
\text { Receiving Pit and } \\
\text { Sample/Weld Station Pit }\end{array}$ & $\begin{array}{l}\text { FDI Log \#CN-1252 File } \\
104.2,9 / 23 / 99\end{array}$ & - \\
\hline Containment Tent & $\begin{array}{l}\text { Enclosure for Receipt of or } \\
\text { High pressure Casks (Off } \\
\text { Normal) }\end{array}$ & $\begin{array}{l}\text { FDI Log \#CN-1259 File } \\
104.2,11 / 8 / 99\end{array}$ & - \\
\hline Block Diagram & Process Block Flow Diagrams & In Process & H-2-123400, Sheets 1-12 \\
\hline
\end{tabular}

*Note: These features were subsequently removed from the scope of the SNF CSB Sub-project.

The vendor-supplied designs were reviewed by FDI/DESH and documented in FDI conference notes as listed in Table 2. Comments from all of the PHMC package reviews are located in the FDI conference notes. The largest procurement package (MHM) underwent a formal design review and is documented in the MHM 100\% Design package, vendor file \#VI-50100. After the formal design review, changes were made to the MHM Design Requirements. The modified design was independently reviewed and documented in the following letters: [MHM-BTR-092-R.1], [DESH-9761988.1]; [MHM-BTR-101], 
[DESH-9860199]; and [MHM-BTR-111], [DESH-9851598]. Independent reviews of the seismic analysis for the MHM are documented in [FDP-591], [DESH-9853642], and [DESH-9760886].

Other documentation of design verification activities, e.g., independent reviews, informal/formal design reviews, and alternate calculations, performed on the CSB SSCs is contained in the following documents.

Independent reviews conducted on the CSB design documentation and CSB SSCs are documented in:

- 99-SNF/CES-001, Interoffice Correspondence, "MCO Machine - Shield Skirt/Concrete Deck Interface - Technical Evaluation," C. E. Swenson to A. S. Daughtridge, dated November 2, 1999, containing an unreleased copy of HNF-5297, "Radiation Exposure from the Gap Under the MultiCanister Overpack (MCO) Handling Machine," S. R. Gedeon, FDNW, October 1999."

- CN-1123, "Design Review of SNF CSB Deck Structural Calculations and RCR's," Fluor Daniel, Inc., 1996.

- DESH-9760886, "Review of Soil and Building Structural Interaction on Seismic Response Spectra for CSB Receiving and Multi-Canister Overpack Handling," DE\&S Hanford, Inc., 1997.

- DESH-9853642, "Review Comments to Seismic Analysis and Structural Calculations," DE\&S Hanford, Inc., 1998.

- FDP-591, "Multi-Canister Overpack Handling Machine Seismic Analysis Review Report," Fluor Daniel, Inc., 1998.

Formal reviews have been completed and documented in the following:

- FDH-9655540, "Security Concept and Design Criteria, 100\% Design Review for the Canister Storage Building and Hot Conditioning System Annex," letter; E. S. McGinley, FDH, to F. G. Hudson, DESH, dated May 19, 1997.

- SNF-5222, Rev. 0, “SNF MCO Design Review Completion Report," L. H. Goldmann, Fluor Daniel Hanford, 1999; containing HNF-SD-SNF-RPT-011, Rev 1A, "SNF Project Design Basis Capacity Study,” K. J. Cleveland, Fluor Daniel Northwest, 1999.

- SNF-5465, "SNF MCO Design Verification Summary," L. H. Goldmann, Fluor Daniel Hanford, 1999.

Design compliance matrices have been completed and informally reviewed as documented on the EDTs as follows:

- 00-SNF/CES-005, "Project Number W-379 - Multi-Canister Overpack Handling NOG-1 Compliance Matrix," SNF Project Internal Correspondence, C. E. Swensen to G. D. Bazinet, May $11,2000$. 
- HNF-4742, Rev. 0, "CSB Compliance Assessment, DOE Order 6430.1A, General Design Criteria," D. M. Black, Fluor Daniel Northwest, 1999.

- HNF-4776, Rev. 0, “CSB Compliance Assessment, SNF Project NRC Equivalency Criteria," D. M. Black, Fluor Daniel Northwest, 2000.

- SNF-5790, Rev. 0, "Design Compliance Matrices to ANSI and OSHA," S. A. Krieg, FDH, 2000.

Alternate calculations have been completed as follows:

- EDT-625800, "Preliminary Analysis of MCO Loading During CSB Startup." A. L. Pajunen, DESH, December 1, 1998 (Contains Independent analysis by Q Metrics on natural convective cooling). Alternate calculation of CSB-HV-0010, "CSB Vault Air Temperatures".

- SNF-5930, Rev. 0, "Structural Analysis of MCO for Accidental Movement of MHM During MCO Lifting Operations," G. D. Bazinet, NHC, and G. Abatt, March 2, 2000 (Contains Independent Analysis of MCO Critical Failures by M\&D Associates). Alternate calculation of CSB-S-0007 "Storage Tube Analysis \& MCO Drop", CSB-S-0067 "MCO Drop Impacts on the Standard Storage Tubes", and CSB-S-0068 "MCO Drop Impacts on the Overpack Storage Tubes".

Computer code validation and verification:

- FDP-815, "Validation and Verification of Computer Codes Used For Spent Nuclear Fuel CSB," letter S. L. Petersen FDNW, to A. S. Daughtridge, DESH, dated March 11,1999.

Informal reviews have been completed and documented on EDTs on the following:

- HNF-3553, Annex A, Rev. 0., Spent Nuclear Fuel Project SAR - Annex A Canister Storage Building." R.P. DiPiazza, 2000.

- HNF-3553, Vol. 1, Rev. 0A., Spent Nuclear Fuel Project Final Safety Analysis Report.” L. J. Garvin, 2000.

- HNF-3672, Rev 0., "Canister Storage Building Safety Requirements.” D.E. Krahn, 2000.

- HNF-6025, Rev. 0, "Emergency Preparedness Hazards Assessment," L.R. Campbell, dated May 24, 2000 .

- HNF-SD-SNF-CSER-005, "Criticality Safety Evaluation Report for the MCO," S. F. Kessler, FFS, 2000 .

- HNF-SD-SNF-FHA-002, Rev. 2., "Final Fire Hazards Analysis for the Canister Storage Building," ARES report, 2000.

- SNF-6449, Rev. 0, "FMEA/RAM Analysis for the MHM," EDT 628719, 6/1/00. 
The following documents underwent an informal review with the FSAR as documented in the EDT:

- SNF-3907, Rev. 0, "SNF Project CSB Human Factors Engineering (HFE) Analysis: Results and Findings," R. P. DiPiazza, 1999.

- SNF-4831, Rev. 0, "Human Factors Engineering and Ergonomics Analysis for the CSB: Results and Findings," R. P. DiPiazza, 1999.

- SNF-3328, Rev. 2, "Canister Storage Building Design Basis Accident Analysis Documentation," R. D. Crowe, M. G. Piepho, et.al., FH, 2000.

- HNF-SD-SNF-HIE-001, "Canister Storage Building Hazard Analysis Report,” L.J. Garvin, 1997.

\subsubsection{CONSTRUCTION AND STARTUP PHASE}

Verification of the CSB SSCs meeting their associated requirements during the construction and startup phases of Sub-project W379 can be broken into fjve types of verification:

- Review of vendor supplied designs

- Factory Acceptance Tests (FATs)

- Construction Acceptance Tests (CATs)

- Pre-operational Acceptance Tests (PATs)

- As-Built Verification

Each of the 23 systems of the CSB is described in Table 3 along with their associated design verification. This testing verifies the design of the CSB SSCs by ensuring that the systems are within dimensional bounds; perform the required control or actuation; provide the required flow and/or pressure drop; or otherwise perform their required function. The systems and their required testing are outlined in the W379 Test Specifications. Below is a description of the testing process used on the CSB.

The Design Authority, Design Agent, construction contractor, or vendors, assist in the preparation and/or review of the detailed FAT test procedures and acceptance criteria. FATs typically occur at the vendor's site and verify that the SSC meets the requirements of the procurement specification. FATs can be dimensional in nature, test component actuation, simulate inputs and logic controls, provide load tests, hoist speeds, leak tests, etc. Factory acceptance tests are approved by the Design Agent and the Design Authority and are controlled by the construction contractor.

During the construction phase, the Start-up organization, with input from the Design Agent and Design Authority, developed the Test Specifications. The Test Review Board (TRB), formerly the Joint Test Group (JTG), and the Design Authority performed an independent review of the Test Specifications (see JTG/TRB meeting minutes listed in Appendix A). The Test Specifications reviewed the adequacy 
of the FATs and developed the requirements for the CAT's and PATs. The CATs are approved by the Design Agent and the Design Authority and atre controlled by the consuruction contractor.

The Pre-operational Acceptance Test procedures that were developed contain the traditional Acceptance Testing Procedure (ATP) content with the physical and functional testing content of traditional Operational Testing Procedures (OTP). These PAT procedures also underwent independent reviews by the TRB and informal review by Design Authority as listed in Appendix A.

A compilation of the qualification testing of each of the CSB sub-systems is, or will be, documented in a Test Summary Report or Test Results Package. The Test Summary Report is the culmination of a process to document the portions of the system needing testing, the procedure for executing the tests, and the test results. The Test Summary Reports also undergo an independent review by the TRB. A list of the Test Summary Reports and the references of the independent reviews is contained in Appendix A. In accordance with SNF Project Administrative Procedure AP 10-025-04, Review, Approval, and Disposition of Test Results, interim acceptance of test results prior to completion of the test results package may be accomplished using a Test Acceptance Certification Document certifying that the test is complete as presented and that the test acceptance criteria are met. The test results package that follows will constitute the final record of testing completion.

Testing of future additions to the CSB related to the canister cover cap and welding fixture system and MCO Internal Gas Sampling equipment will be completed as appropriate for those components. The open items related to verification of those requirements are noted in section 3.1 .5 and will be tracked as part of the CSB Facility action tracking system.

As-built verification for essential drawings was performed for both the MHM and the balance of the CSB in accordance with the Verification Plan for As-Builting Canister Storage Building, SNF Desk Instruction (CSB-DI-00I) and the MHM As-Built Verification Plan . C.E. Swenson, (SNF-6448, Rev. 1).

Table 3. CSB Systems and Design Verification

\begin{tabular}{|c|c|c|}
\hline SYSTEM \# & SYSTEM DESCRIPTION & VERIFICATION \\
\hline $1,1 x$ & 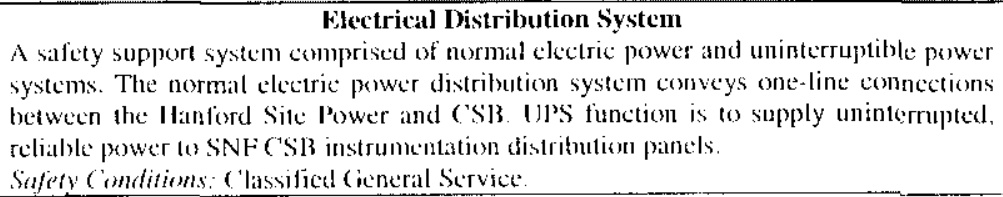 & $\begin{array}{l}\text { Design Revicwed: } \\
\text { Sipperstructure laakinge } \\
\text { Tested: IIPS } \\
\text { W } 379 \text {-PAT-018 }\end{array}$ \\
\hline 2 & 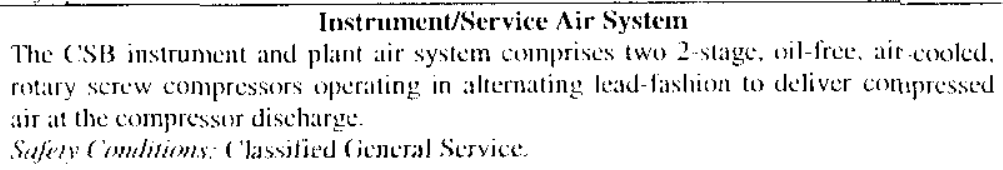 & $\begin{array}{l}\text { Design Reviewed: } \\
\text { Superstructure Packinge } \\
\text { Tested: } \\
\text { W379-PAT-002 }\end{array}$ \\
\hline 3 & 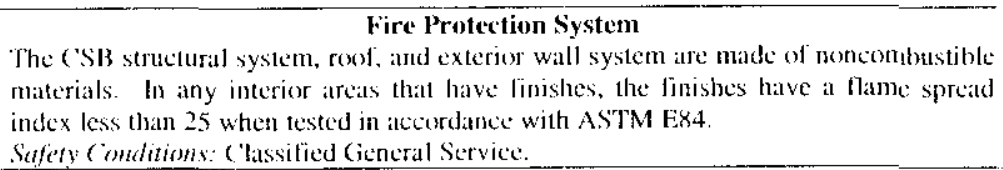 & $\begin{array}{l}\text { Design Reviewed: } \\
\text { Superstrucure package }\end{array}$ \\
\hline 4 & 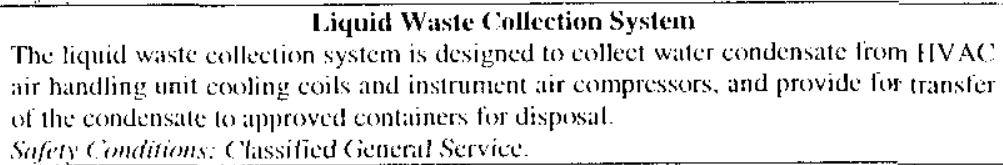 & $\begin{array}{l}\text { Design Reviewed: } \\
\text { Superstructure package } \\
\text { Tested: } \\
\text { W379-PAT-(0)44 }\end{array}$ \\
\hline
\end{tabular}




\begin{tabular}{|c|c|c|}
\hline SYSTEM: & SYSTEM DESCRIPTION & VERIFICATION \\
\hline 5 & $\begin{array}{l}\text { Commonications System } \\
\text { The design of the plant communications system provides the cabling and/or ratcewaly } \\
\text { system equipment for the lelephone, public address, intercom, and radio } \\
\text { communications systems within the CSB to the communications equipment interface } \\
\text { point. } \\
\text { Salety (ombitions: Classified Cicneral Service. }\end{array}$ & $\begin{array}{l}\text { Design Reviewed: } \\
\text { Independent review ol I.S. West } \\
\text { Telephone System and Public } \\
\text { Address System Design } \\
\text { Testcd: Constrtetion Acceplance } \\
\text { Testing summarized in Test } \\
\text { Summary Report W379-TSR-(0)5 }\end{array}$ \\
\hline 6,7 & 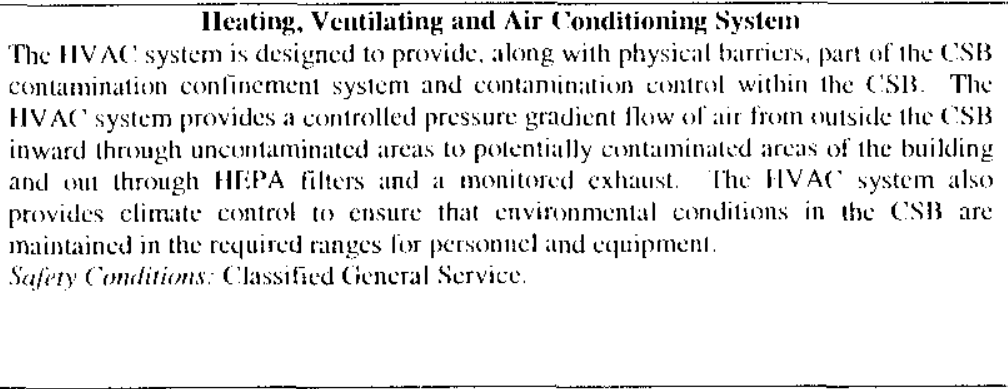 & $\begin{array}{l}\text { Design Reviewed: } \\
\text { Superstructure package } \\
\text { Tested: } \\
\text { Operating Area: } \\
\text { W379-PAT-006 } \\
\text { Support Area: } \\
\text { W370-1'AT'007 } \\
\text { Stack Monitoring Phase 1: } \\
\text { W379-PAT-010-1 } \\
\text { Stack Monitoring Phase 2: } \\
\text { W379-PAT-010-2 }\end{array}$ \\
\hline 8 & 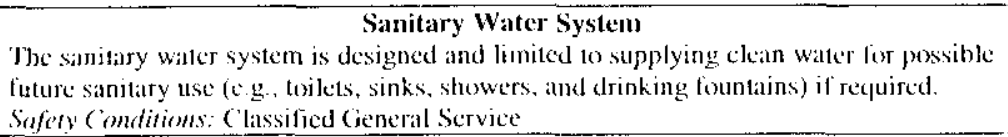 & $\begin{array}{l}\text { Design Reviewed: } \\
\text { Supersiruclure package }\end{array}$ \\
\hline () & 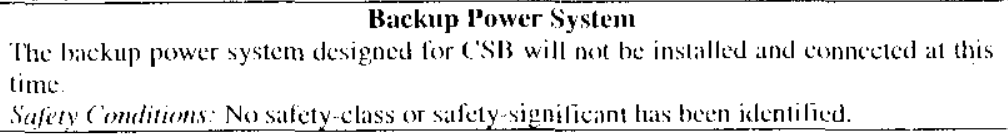 & $\mathrm{N} / \mathrm{A}$ \\
\hline 10,11 & 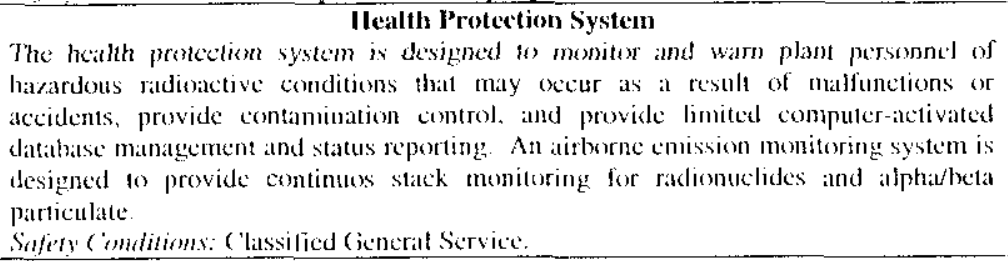 & 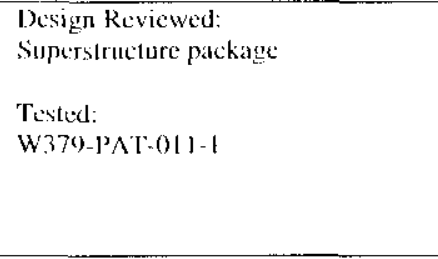 \\
\hline 12 & 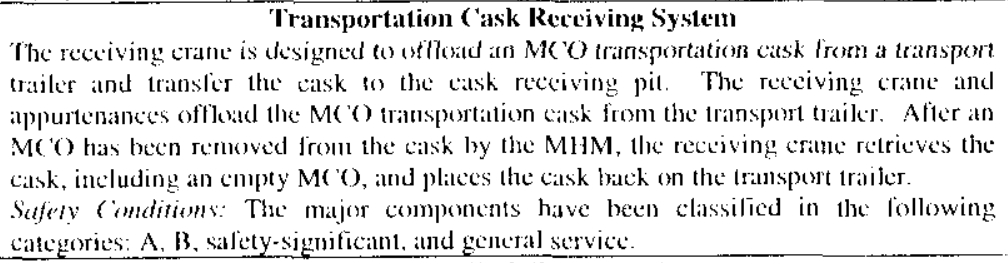 & $\begin{array}{l}\text { Design Reviewed: } \\
\text { Superstructure packiage } \\
\text { 'l'stud: } \\
\text { W379).PAT-0)12 } \\
\text { W370-PAT-(012-1 }\end{array}$ \\
\hline 13 & 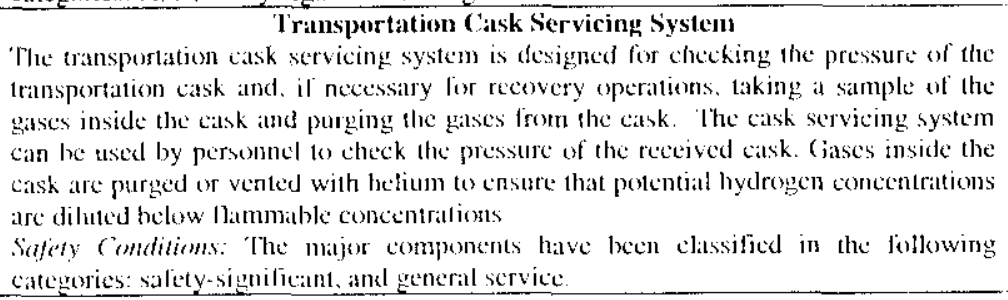 & 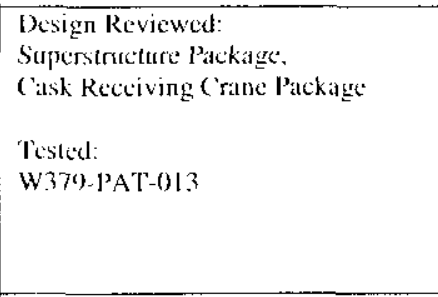 \\
\hline 14 & 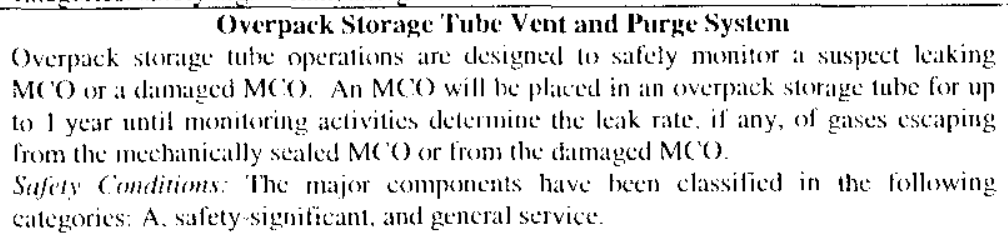 & $\begin{array}{l}\text { Design Reviewed: } \\
\text { Superstructure Package, } \\
\text { Purge Vent System } \\
\text { Tesled: } \\
\text { W-379-1'AT-014-1 } \\
\text { W-379-1'AT'-014-2 }\end{array}$ \\
\hline
\end{tabular}




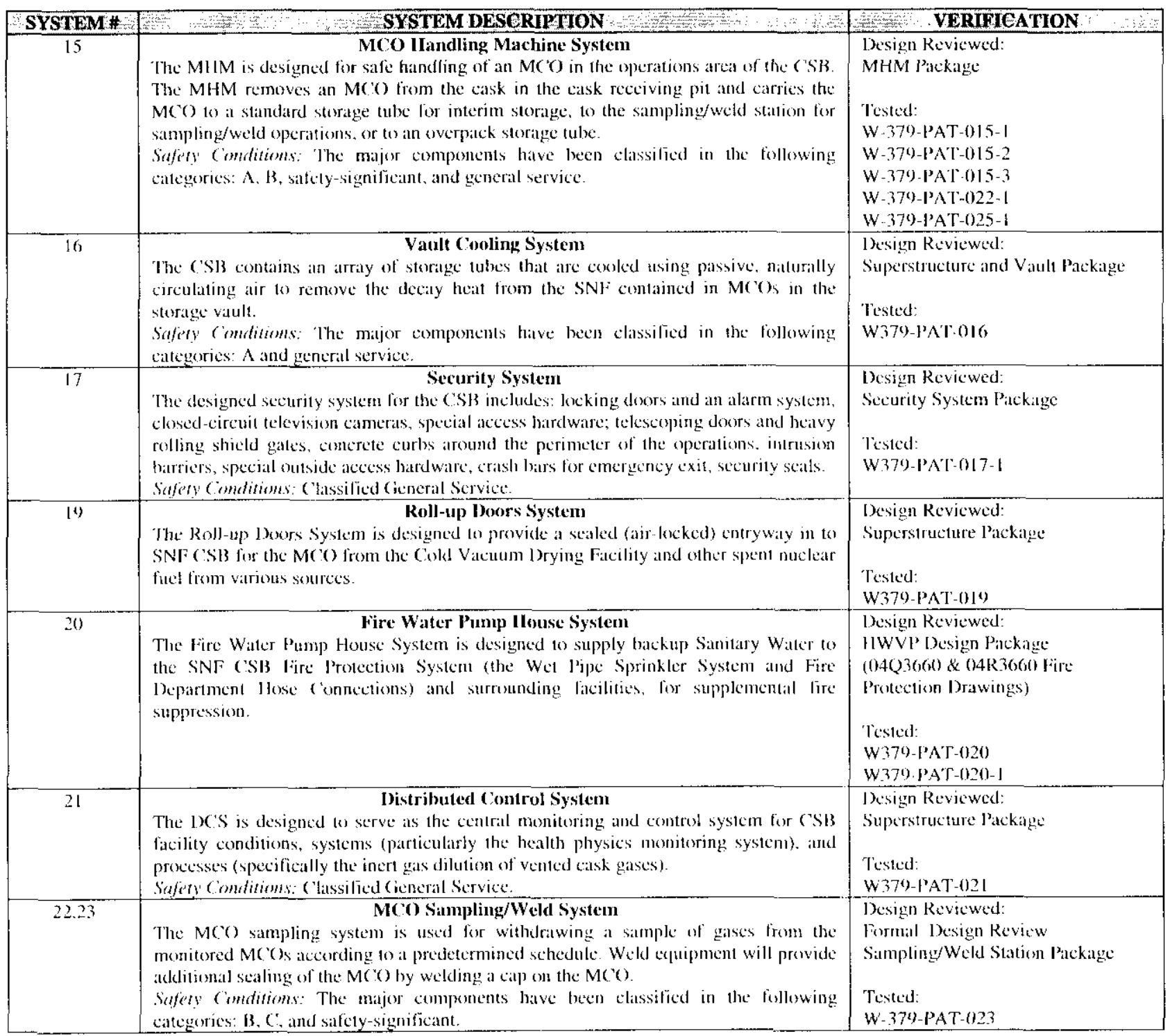

\subsubsection{DESIGN VERIFICATION ACTIVITIES TO BE COMPLEILD}

Verification of future additions to the CSB related to the canister cover cap and welding fixture system and MCO Internal Gas Sampling equipment will be completed as appropriate for those components. The open items related to verilication of those requirements are noted in this section and will be tracked as part of the CSB Facility action tracking system.

\section{HNF-S-0425, Performance Specification for the Spent Nuclear Fuel Canister Storage Building}

a) Verify the capability to receive and handle the MCO canister cover assembly shipments. (Requirement 3.2.1.2.4)

b) Verify functionality of canister cover cap assembly receipt and lag storage area. (Requirement 3.2.2.1.9.11) 
c) Verify performance of CSB workstation enclosures. (Appendix A, Requirement 1.1.2)

d) Verify performance of MCO Internal Gas Sampling/Verification Equipment. (Appendix A, Requirement 1.1.3)

e) Verify performance of Canister Cover Cap Welding Machine. (Appendix A, Requirement 1.1.5)

f) Verify performance for Canister Cover Plate Welding. (Appendix A, Requirement 1.1.6)

g) Verify performance of Dye Penetrant Testing (PT) Equipment. (Appendix A, Requirement 1.1.7)

h) Verify performance of Leakage Rate Testing Equipment. (Appendix A, Requirement 1.1.8)

\subsection{EVIDENCE THAT DESIGN REQUIREMENTS ARE MET}

Current design requirements come from three sources: (1) the Canister Storage Building Performance Specification, [HNF-S-0425, Rev. 4]; (2) the Performance specification for the MHM, [HNF-S-0468, Rev 5]; and (3) the Spent Nuclear Fuel Project Stage and Store K Basin SNF in Canister Storage Building Functions and Requirements, [SD-SNF-FRD-010, Rev. 1].

Evidence that the design requirements in the Performance Specifications listed above are met is contained in Appendix B. Appendix B reviewed Project W379 for compliance to the latest requirements [HNF-S-0425, Rev. 4] and [HNF-S-0468, Rev 5]. Earlier evidence of the design requirements being met includes two Baseline Design Verification Compliance Matrices performed by Fluor Daniel Incorporated [FDI File 106] and FDI, [FRT \#2694].

Compliance of the design with DOE Order 6430.1A and NRC equivalency are documented in compliance documents [HNF-4742] and [HNF-4776]. Design compliance matrices to applicable American National Standards Institute (ANSI) requirements and Occupational Safety and Health Association (OSHA) requirements are contained in [SNF-5790]. Additionally, an ASME Nuclear Overhead Gantry crane requirements (NOG-1) compliance matrix was completed on the MHM SNF Interoffice Correspondence [00-SNF/CES-005].

Additional verification and validation actions were conducted to of the design to provide an additional level of assurance for structures, systems, and components (SSCs) verified through testing and for those designated as safety class or safety significant. These are documented in:

- SNF-7030, CSB Safety Function Verification Report -- Design verification actions for all systems and components identified on the Safety Equipment List (SEL) were $100 \%$ validated using design media, supporting analysis, testing results, commercial grade dedication analysis, and safety analysis reports.

- SNF-7028, CSB Facility Design Validation Assessment - Project W-379 - Where testing was designated as the verification method in this report, validation of all safety class and safety significant items was required. In addition, a sampling basis was used to validate verification tests for general service items. 


\subsection{EVIDENCE THAT DESIGN VERIFICATION REQUIREMENTS ARE MET}

Requirements verification methods are defined in the FDI DCPM. Methods of verification for the requirements are proposed in two sources: (1) The Baseline Design Verification for the CSB, FDI Transmittal to WHC, [FRT-2694], July 1996; and (2) the Test Review Board Meeting minutes. These sources were used to create the Design Requirements Compliance matrix (Appendix B) that listed the verification method used for each of the requirements in the CSB and MHM specifications. Those verification methods included:

- Independent Review

- Alternate Calculations

- Qualification Testing

- Formal Design Review

- Informal Review

Evidence that Sub-project W379 performed the required design verification is contained in the Design Verification Status Questionnaire contained in Appendix C and supported by the List of Project Design and Design Verification Documents in Appendix A and Design Requirement Compliance Matrix in Appendix B.

\subsection{CONCLUSION}

The Canister Storage Building (CSB) subproject has performed thorough and appropriate design verification activities throughout the project life cycle. Proper planning was performed and a graded approach was used based on safety and other project risks. Design verification was performed in accordance with the design agent's Design Control Procedures Manual, as approved by CSB engineering, and included independent, informal, and formal reviews as well as alternate calculations and qualification testing. At all phases of the design, verification activities were conducted in a graded manner appropriate to the complexity and importance to safety of the design being verified. Verification of future additions to the CSB related to the canister cover cap and welding fixture system and MCO Internal Gas Sampling equipment will be completed as appropriate for those components. The open items related to verification of those requirements are noted in section 3.1 .5 and will be tracked as part of the CSB Facility action tracking system.

\subsection{REFERENCES}

00-SNF/CES-005, "Project Number W-379 - Multi-Canister Overpack Handling NOG-1 Compliance Matrix," SNF Project Internal Correspondence, C. E. Swensen to G. D. Bazinet, May 11, 2000. 
95-NMD-081DOE-RL, Letter J.D. Wagoner, DOE-RL, to Dr. A.L. Trego, Westinghouse Hanford Company, K Basins Path Forward Approval of Mission Need, dated June 13, 1995.

97-SNF-117, "RAM Analysis for the MHM," Letter S. A. Daughtridge, Duke Engineering \& Services, to N. H. Williams, Fluor Daniel Hanford, DESH-97606888, dated November 26, 1997.

99-SNF/CES-001, Interoffice Correspondence, "MCO Machine - Shield Skirt/Concrete Deck Interface - Technical Evaluation," C. E. Swenson to A. S. Daughtridge, dated November 2, 1999, containing an unreleased copy of HNF-5297, "Radiation Exposure from the Gap Under the Multi-Canister Overpack (MCO) Handling Machine," S. R. Gedeon, Fluor Daniel Northwest, October 1999.

AP-EN-6-027-01, "Design Verification Process," Fluor Daniel Hanford, 1999.

CN-1123, "Design Review of SNF CSB Deck Structural Calculations and RCR's," Fluor Daniel, Inc., 1996.

CSB-DI-001, "Verification Plan for As-Builting Canister Storage Building," desk instruction dated November 15, 1997.

DESH-9760886, "Review of Soil and Building Structural Interaction on Seismic Response Spectra for CSB Receiving and Multi-Canister Overpack Handling," Duke Engineering \& Services Hanford, 1997.

DESH-9853642, "Review Comments to Seismic Analysis and Structural Calculations," Duke Engineering \& Services Hanford, 1998.

EDT-612984, “H-2-825867 and H-2-825868, SNF Project Process Flow Diagram Summary,” A.L. Pajunen, Westinghouse Hanford Company, 1995.

EDT-625800, "Preliminary Analysis of MCO Loading during CSB Startup." A. L. Pajunen, Duke Engineering \& Services Hanford, December 1, 1998 (Contains Independent analysis by Q Metrics on natural convective cooling).

EDT-627041, Independent Analysis of MCO Critical Failures by M\&D Associates.

FDH-9655540 R1 "100\% Design review for the Canister Storage Building and Hot Conditioning System Annex." Letter, E. S. McGinley, Fluor Daniel Hanford, to F. G. Hudson, Duke Engineering \& Services Hanford, dated May 19, 1997.

FDH-9655540, "Security Concept and Design Criteria, 100\% Design Review for the Canister Storage Building and Hot Conditioning System Annex," letter; E. S. McGinley, Fluor Daniel Hanford, to F. G. Hudson, Duke Engineering \& Services Hanford, dated May 19, 1997.

FDI DCPM Document; Spent Nuclear Fuel Canister Storage Building Design Control Procedures Manual.

FDP-591, "Multi-Canister Overpack Handling Machine Seismic Analysis Review Report," Fluor Daniel, Inc., 1998. 
FDP-815, "Validation and Verification of Computer Codes Used For Spent Nuclear Fuel CSB," letter S. L. Petersen Fluor Daniel Northwest, to A. S. Daughtridge, Duke Engineering \& Services, dated March 11,1999.

File 106, Fluor Daniel Internal Log, "Vault Baseline Design Verification;" Interoffice Correspondence, dated April 12, 1996.

FRF-2717, "Technical Baseline and Design to Cost CS \& SR Cost Data," Letter, R. S. Poultier, Fluor Daniel, Inc., to M. K. Mahaffey, Westinghouse Hanford Corporation, dated October 9, 1995.

FRF-2717, “Technical Baseline and Design to Cost CS \& SR Cost Data," Letter, R. S. Poulter, Fluor Daniel, Inc., to M. K. Mahaffey, Westinghouse Hanford Corporation, dated October 9, 1995.

FRP-061, "Spent Nuclear Fuel Canister Storage Building Detailed Design Report," Transmittal letter, E. R. Jacobs, Fluor Daniel, Inc., to M. K. Mahaffey, Westinghouse Hanford Corporation, dated August 23, 1996.

FRT-2661, “CSB Interim Design Report,” Fluor Daniel, Inc., dated February, 1996.

FRT-2694, "Baseline Design Verification for the SNF CSB," Fluor Daniel, Inc., dated June 24, 1996.

HNF-1613, Rev. 1, "Spent Nuclear Fuels Engineering Practices," W. C. Miller, Numatec Hanford Corporation, 1999. [This document deleted and superseded by the SNF Project Administrative Procedures]

HNF-4742, Rev. 0, “CSB Compliance Assessment, DOE Order 6430.1A, General Design Criteria,” D. M. Black, Fluor Daniel Northwest, 1999.

HNF-4776, Rev. 1, “CSB Compliance Assessment, SNF Project NRC Equivalency Criteria,” D. M. Black, Fluor Federal Services, 2000.

HNF-6025, Rev. 0, “ Emergency Preparedness Hazards Assessment,” L.R. Campbell, Fluor Hanford, Inc., 2000.

HNF-PRO-1819, "Engineering Requirements," Fluor Hanford, Inc..

HNF-S-0425, Rev. 4, "Performance Specification for the Spent Nuclear Fuel Canister Storage Building," G. D. Bazinet, Numatec Hanford Company, 2000.

HNF-S-0468, Rev 5, "Specification for the MCO Handling Machine," C. E. Swenson, Fluor Hanford, Inc., 1999.

HNF-SD-SNF-CSER-005, Rev. 5B, "Criticality Safety Evaluation Report for the MCO," S. F. Kessler, Fluor Federal Services, 2000.

HNF-SD-SNF-FHA-002, Rev. 2, "Final Fire hazards Analysis for the Canister Storage Building," G. D. Bazinet, Numatec Hanford Company, 2000. 


\section{SNF-6442 REV 1}

HNF-SD-SNF-FRD-010, Rev. 2, "SNF Project Stage and Store K Basin SNF in CSB, Functions and Requirements," M. J. Klem, COGEMA, 2000.

HNF-SD-SNF-HIE-001, Rev. 3, "Canister Storage Building Hazard Analysis Report," T. B. Powers, Fluor Federal Services, 2000.

HNF-SD-SNF-OCD-001, Rev. 4B, "SNF Project Product Specification," A. L. Pajunen, Fluor Hanford, Inc., 2000.

HNF-SD-SNF-RPT-011, Rev. 2, "SNF Project Design Basis Capacity Study," K. J. Cleveland, Fluor Federal Services, 2000.

HNF-SD-SNF-TI-015, Rev. 6, "SNF Project Technical Databook," M. A. Reilly, Duke Engineering \& Services Hanford, 1998.

SNF-3328, Rev. 2, "Canister Storage Building Design Basis Accident Analysis Documentation," R. D. Crowe, M. G. Piepho, et.al., Fluor Hanford, Inc., 2000.

SNF-3907, Rev. 0, "SNF Project CSB Human Factors Engineering (HFE) Analysis: Results and Findings," R. P. DiPiazza, Xwest, 1999.

SNF-4831, Rev. 0, "Human Factors Engineering and Ergonomics Analysis for the CSB: Results and Findings," R. P. DiPiazza, Xwest, 1999.

SNF-5222, Rev. 0, “SNF MCO Design Review Completion Report,” L. H. Goldmann, Fluor Daniel Hanford, Inc., 1999.

SNF-5465, Rev. 0A, "SNF MCO Design Verification Summary," L. H. Goldmann, Fluor Hanford, Inc., 2000 .

SNF-6253, Rev. 1, "Canister Storage Building Acceptance for Beneficial Use Index - Roadmap of Supporting Documents,” G. D. Bazinet, Numatec Hanford Company, 2000.

SNF-6448, Rev. 1, “MHM As-Built Verification Plan,” C. E. Swenson, Fluor Hanford, Inc., 2000.

SNF-7028, Rev. 1, “CSB Facility Design Validation Assessment - Project W-379,” B. Knutson, et al, Parsons Infrastructure \& Technology Group, Inc., 2000.

SNF-7030, Rev 1, "CSB Safety Function Verification Report," R. M. Yanochko, et al, Fluor Hanford, Inc., 2000.

SNF-CO-9911443, "CSB As-Built Verification Program Review," letter S. L. Petersen, Fluor Daniel Northwest, to A. S. Daughtridge, Duke Engineering and Services, dated March 29, 1999.

VI-50100,Vender File with MHM 100\% Design Package.

WHC-CM-6.1, "Standard Engineering Practices," EP 4.1, "Design Verification," Westinghouse Hanford Company. 
WHC-EP-0830, Rev. 0, "Hanford Spent Nuclear Fuel Project Recommended Path Forward," J. C. Fulton, Westinghouse Hanford Company, 1994.

WHC-SD-W379-CDR-001, Rev. 0, "Spent Nuclear Fuel Canister Storage Building Conceptual Design Report," C. E. Swenson, Westinghouse Hanford Company, 1996.

WHC-SD-W379-DR-001, Rev. 0, "SNF CSB Conceptual Design Report Review Committee Report," W. P. Dana, Westinghouse Hanford Company, 1995.

WHC-SD-W379-ES-002, Rev. 0, "Staging and Storage Facility Feasibility Study Final Report,” M. D. Conner, Westinghouse Hanford Company, 1996.

WHC-SD-W379-ES-003, Rev. 0, “CSB Trade Study Final Report,” M. D. Conner, Westinghouse Hanford Company, 1995. 
SNF-6442 REV 1

APPENDIX A

\section{LIST OF PROJECT DESIGN, CONSTRUCTION, AND}

DESIGN VERIFICATION DOCUMENTS

A-1 
SNF-6442 REV 1

This page intentionally left blank.

A-2 


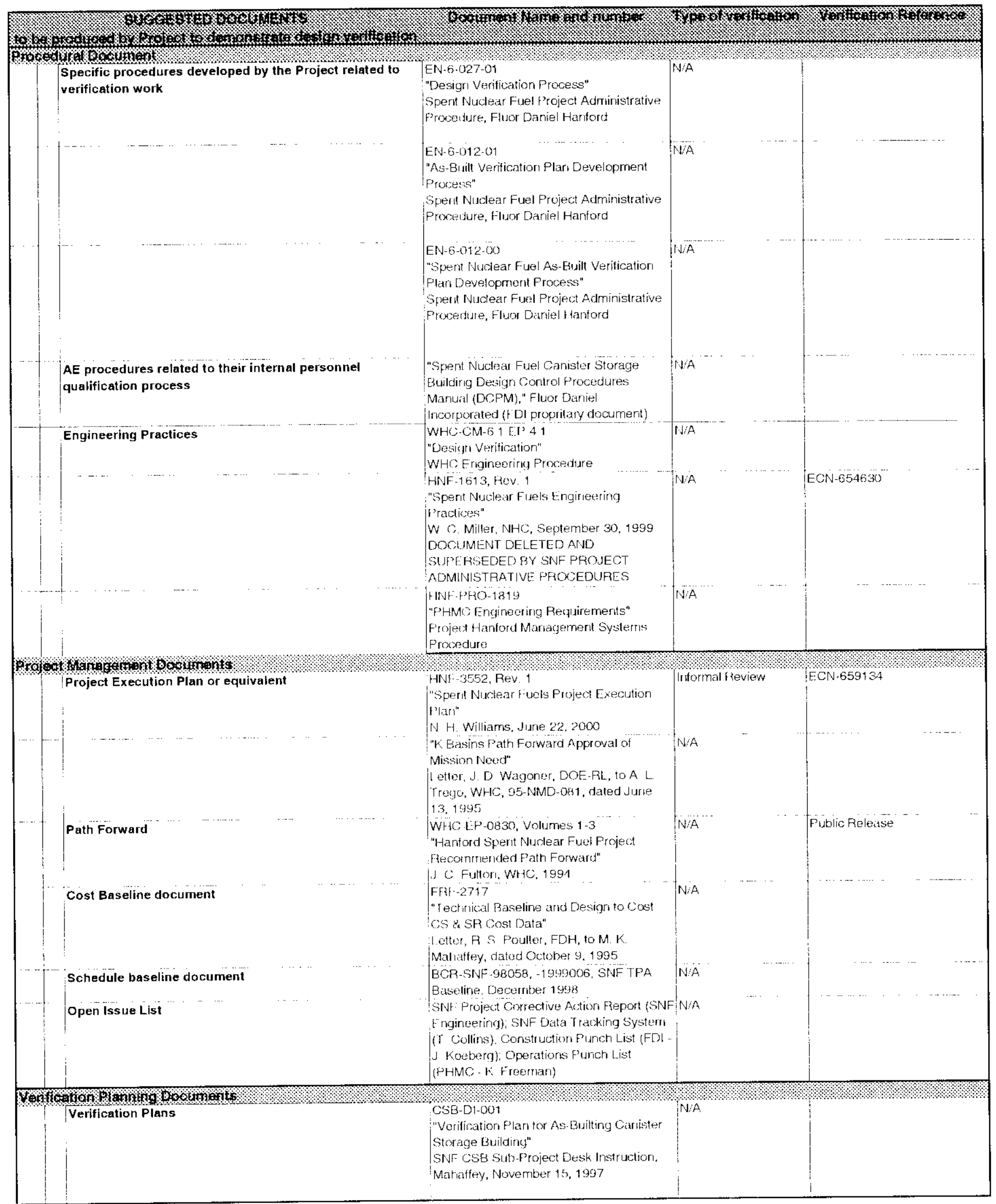




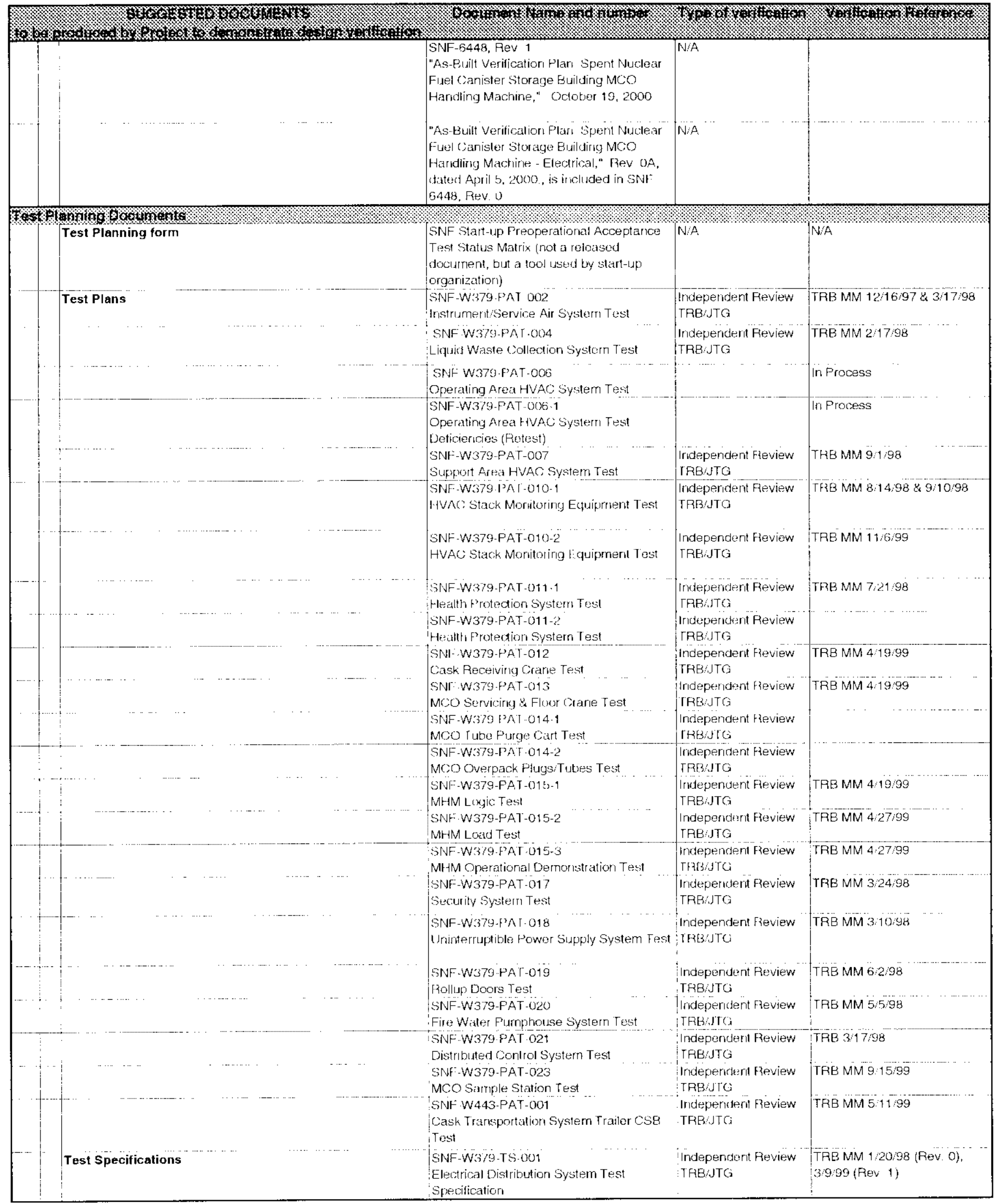




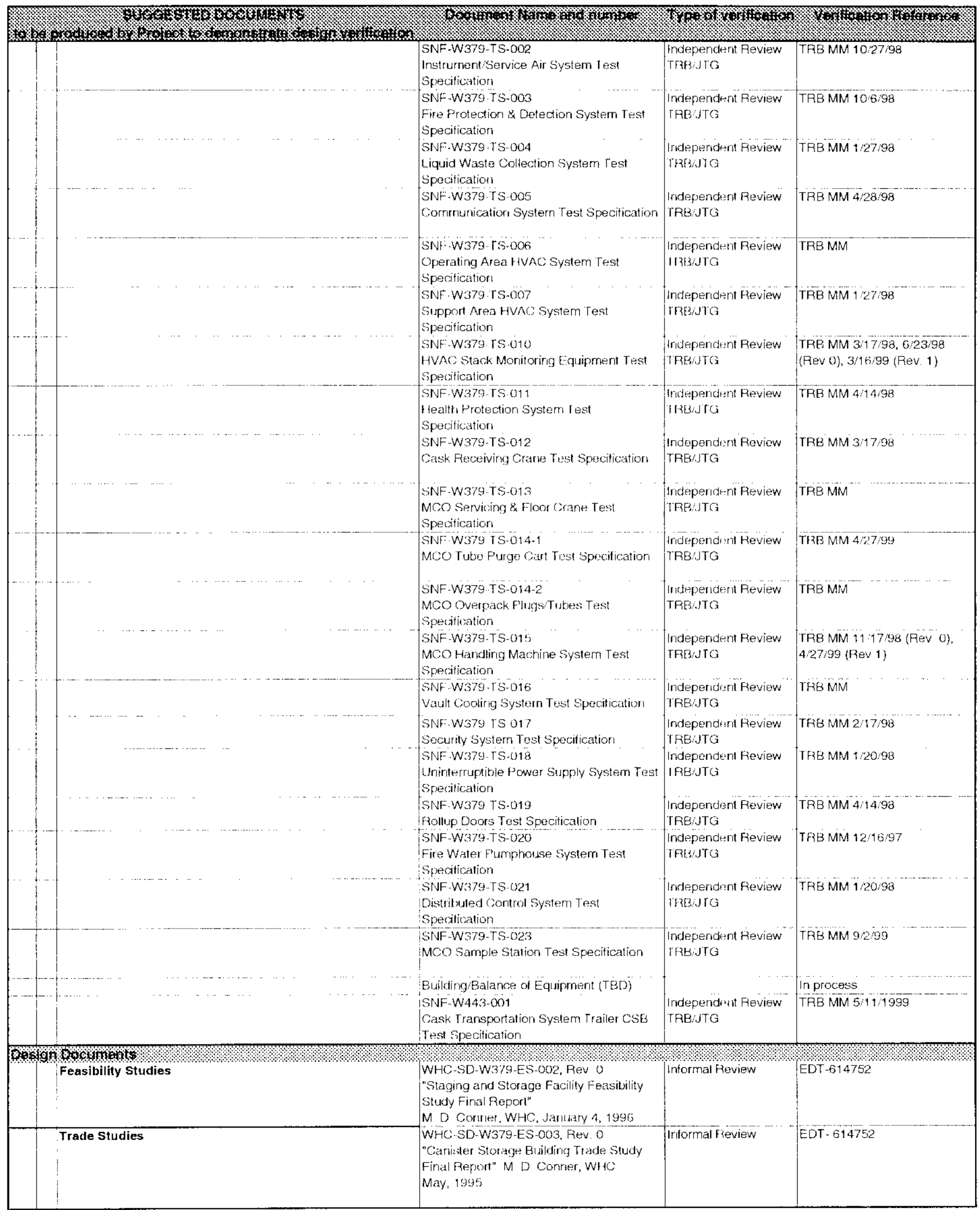




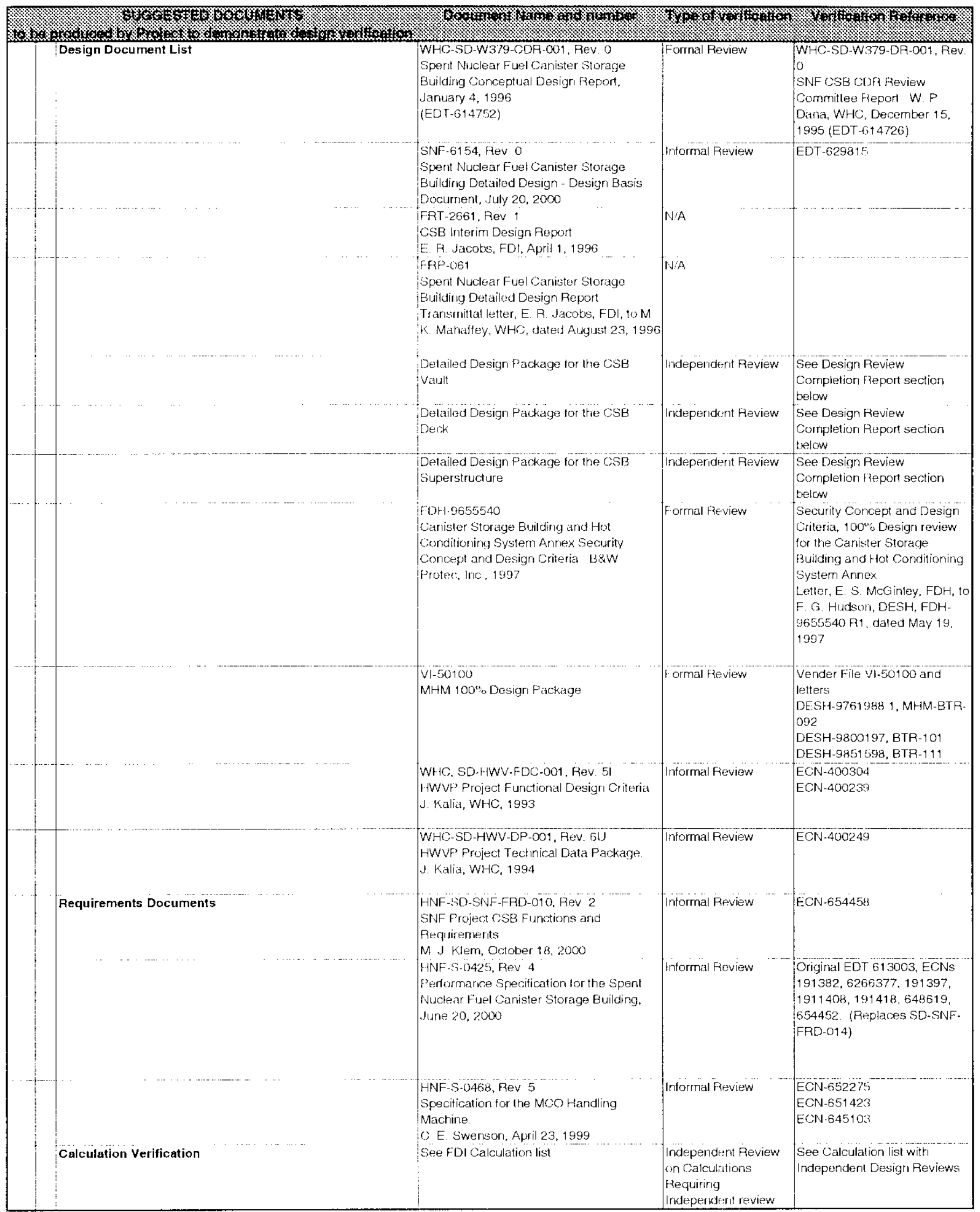




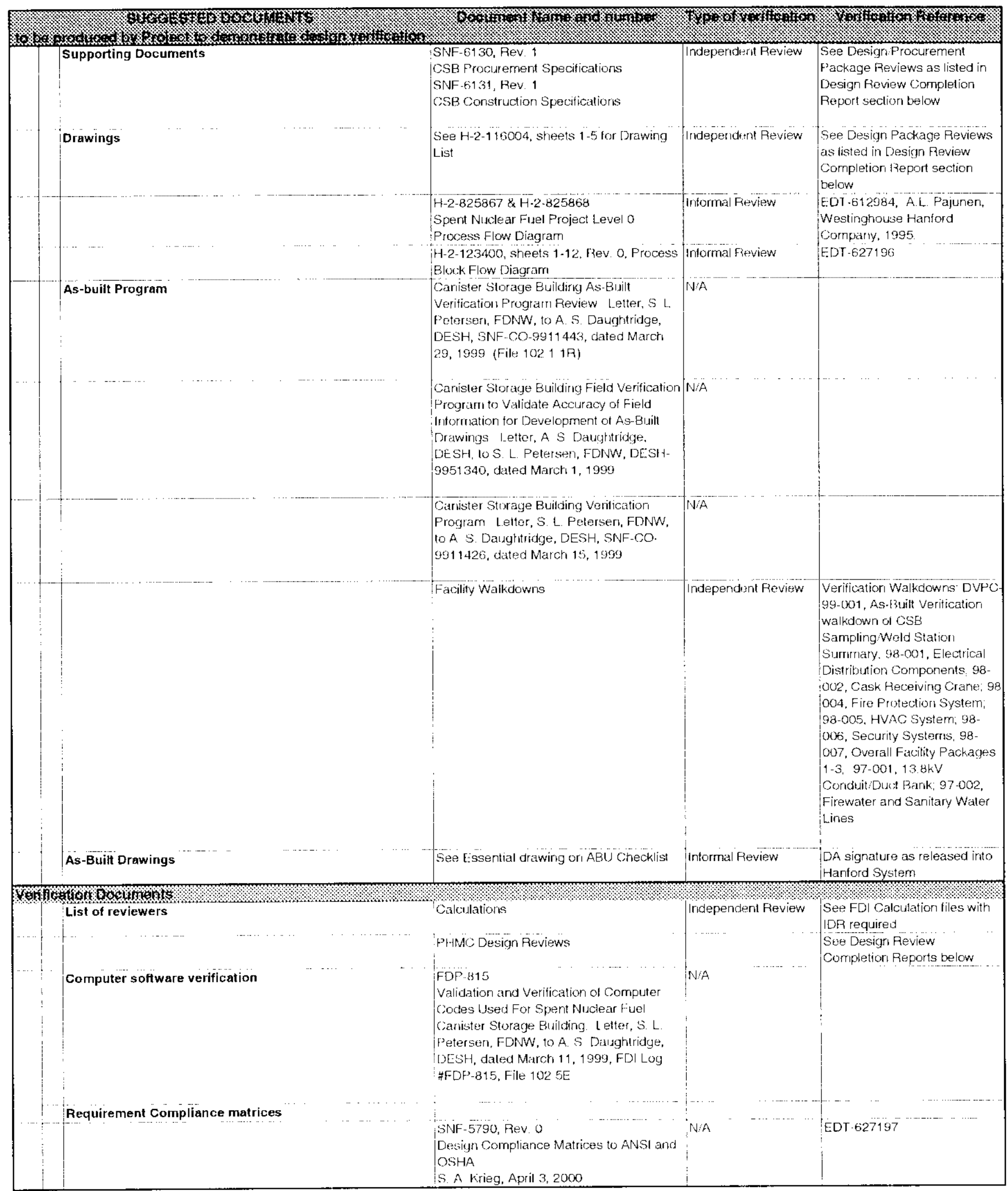




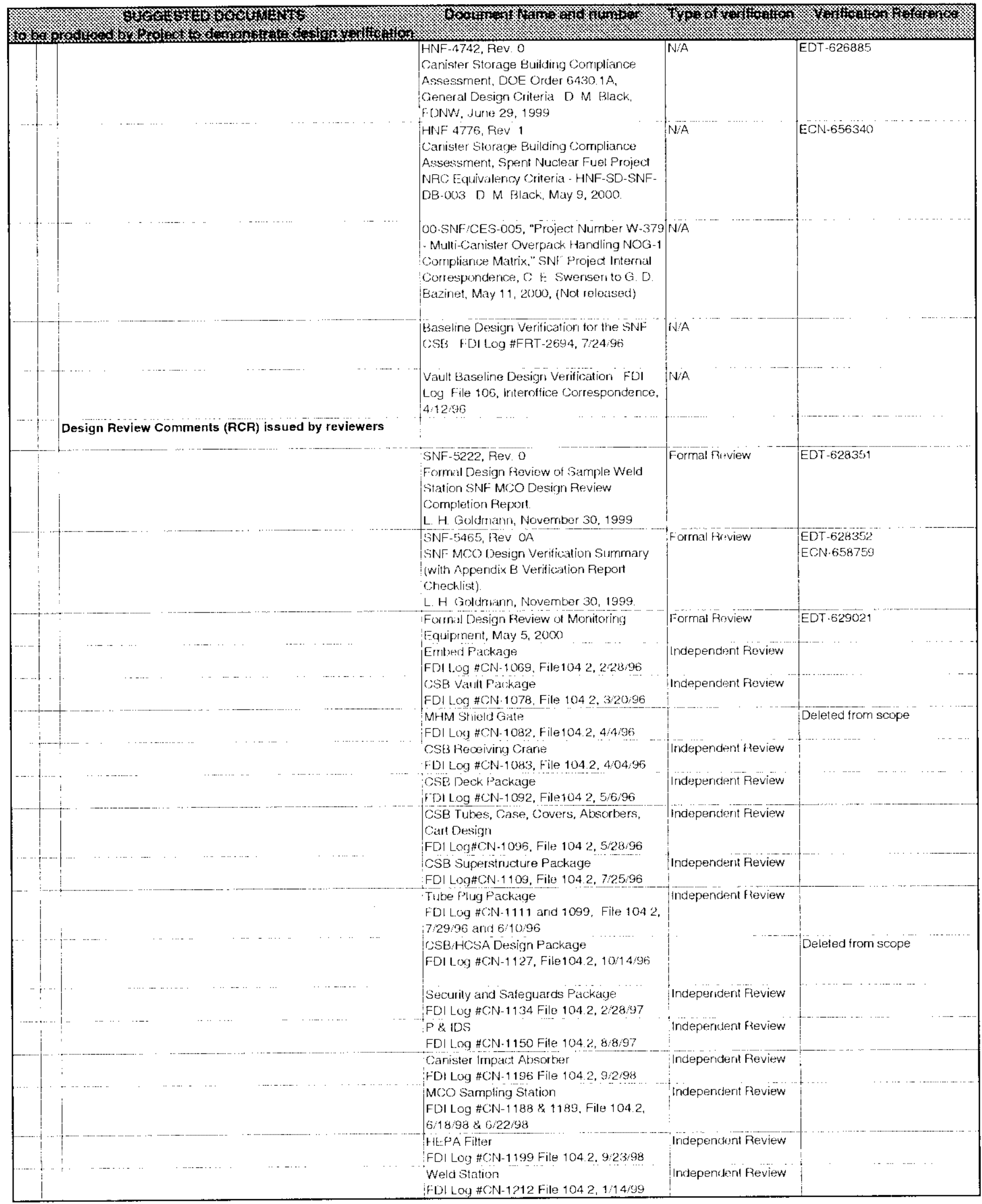




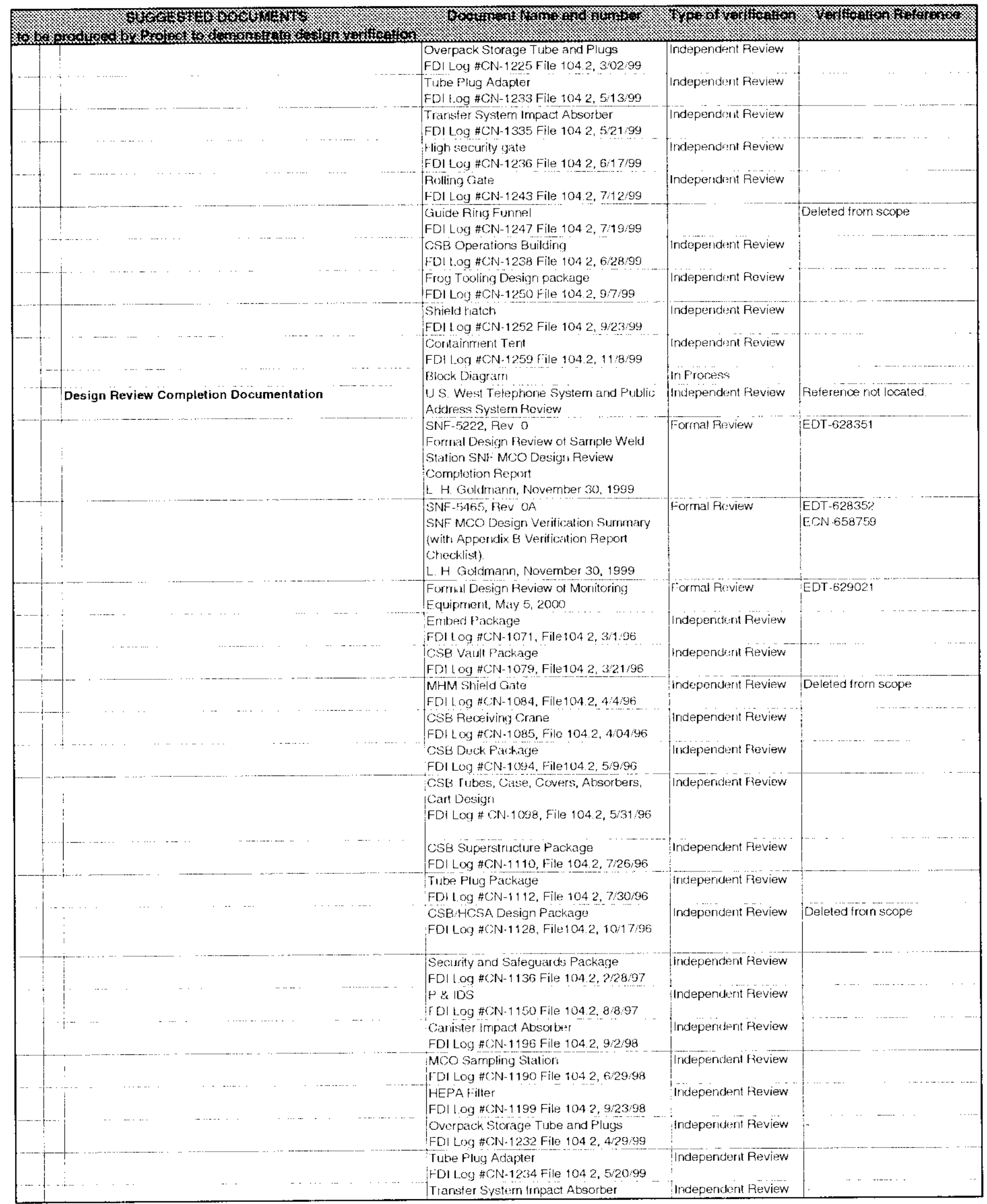




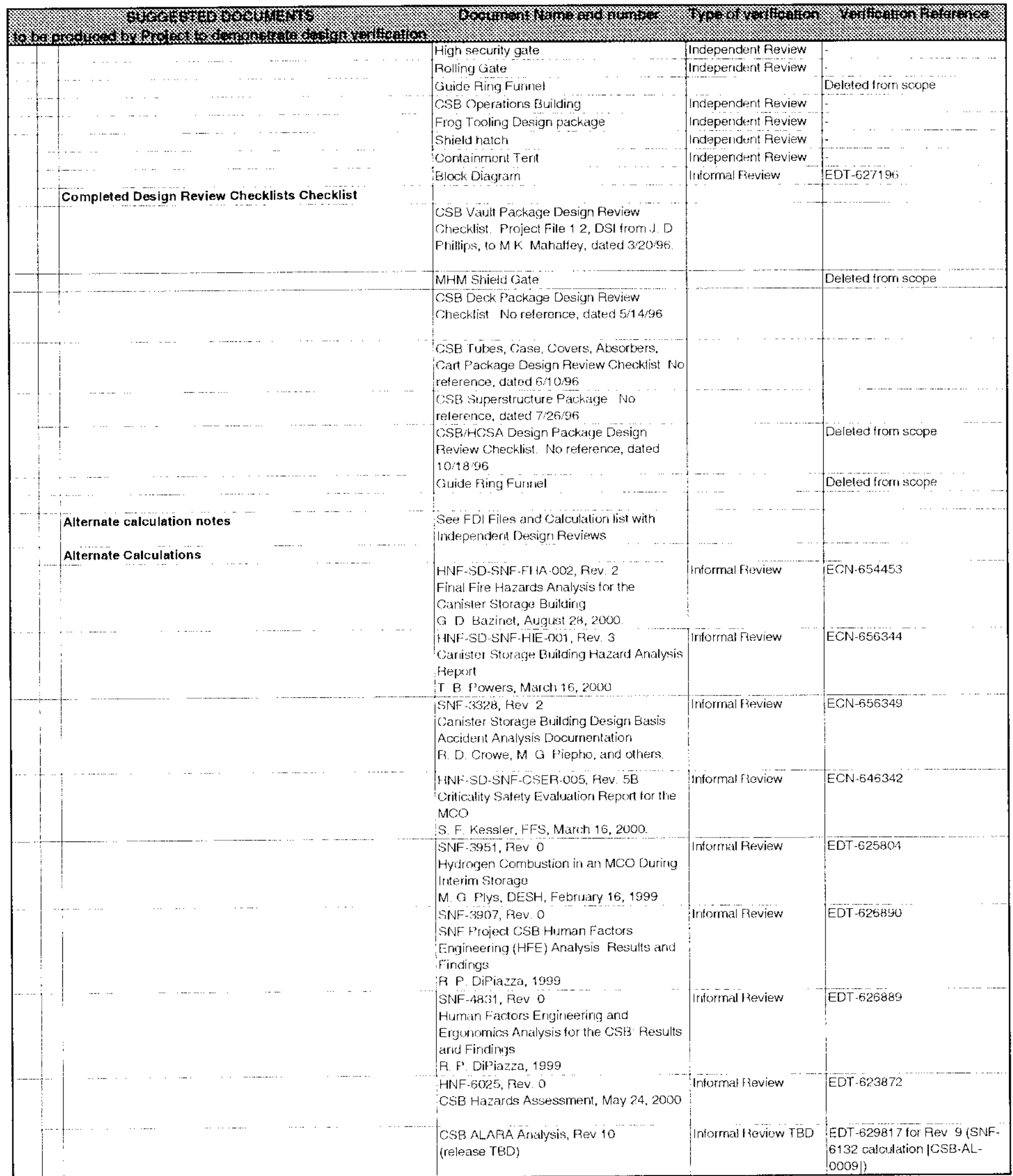




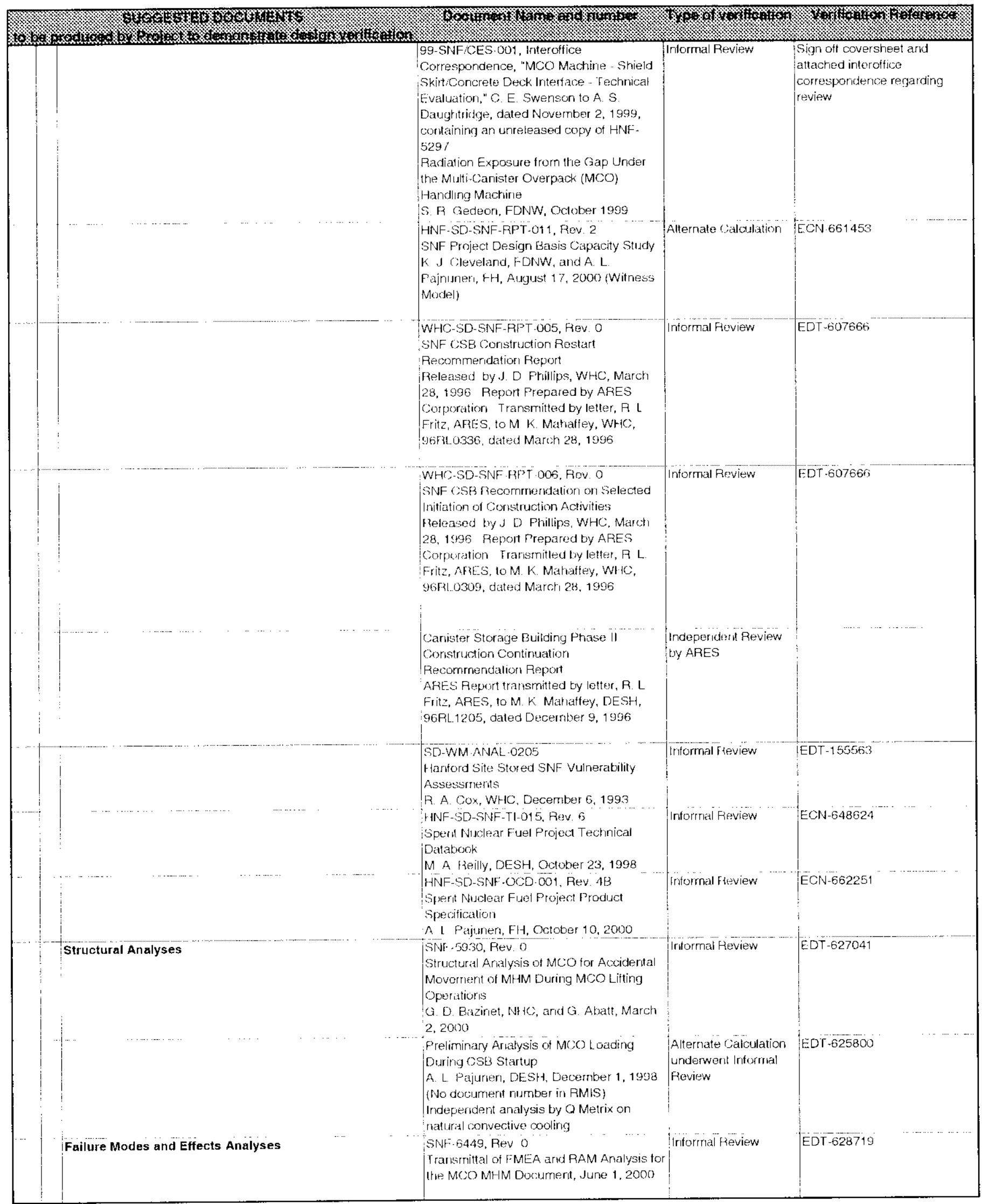




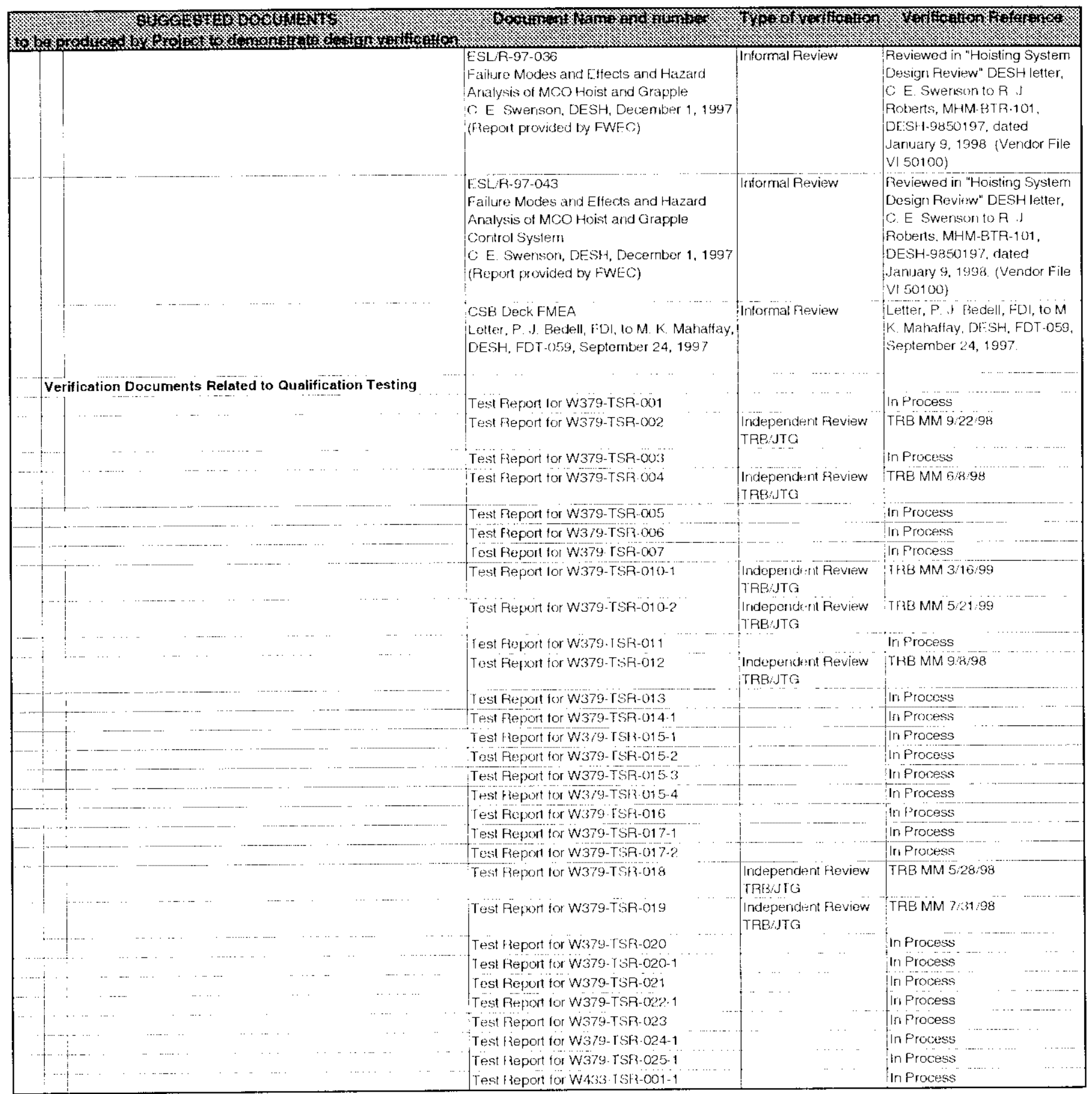


SNF-6442 REV 1

APPENDIX B

DESIGN REQUIREMENT COMPLIANCE MATRIX

B-1 
SNF-6442 REV 1

This page intentionally left blank.

B-2 


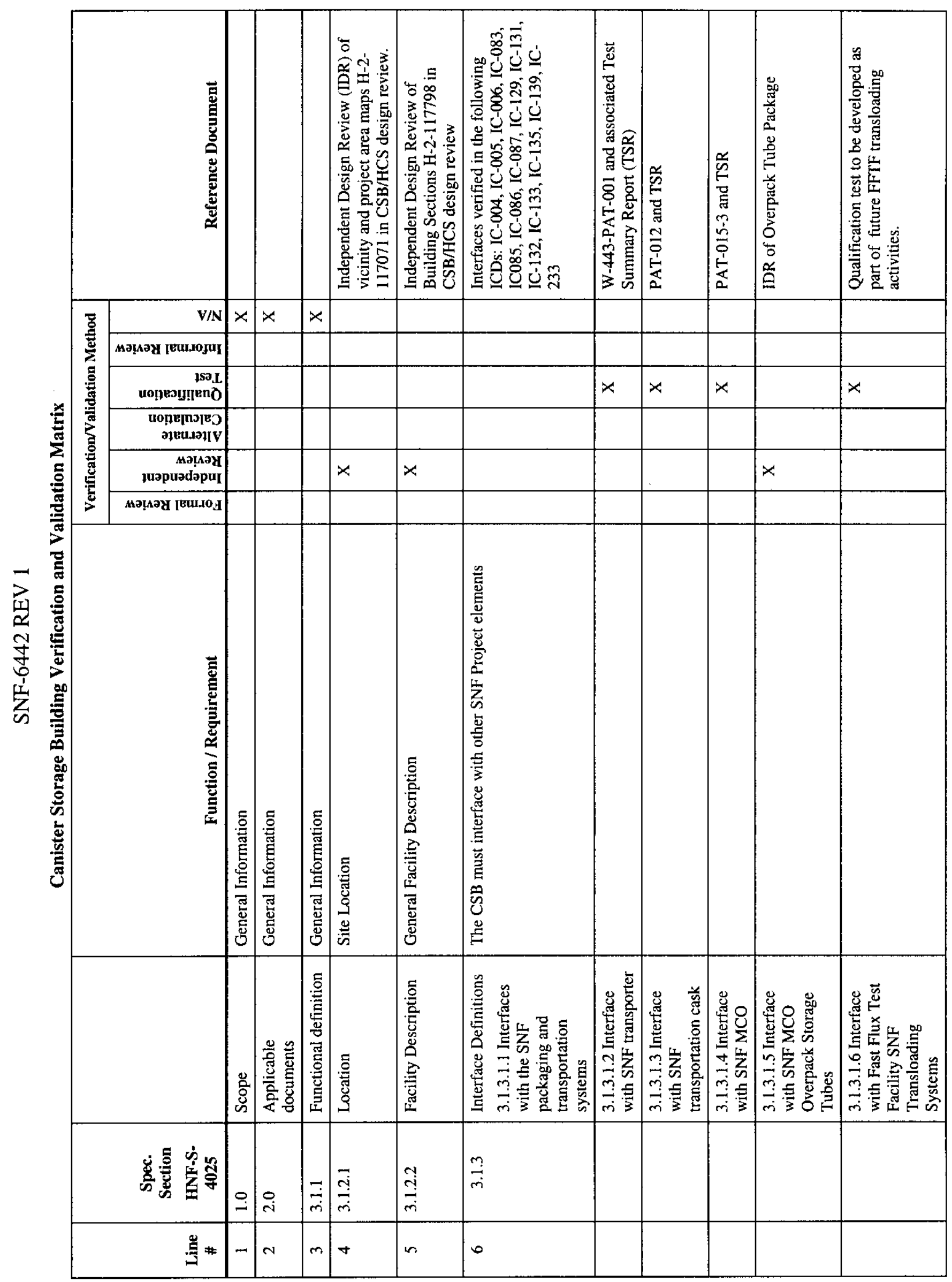

$m$ 


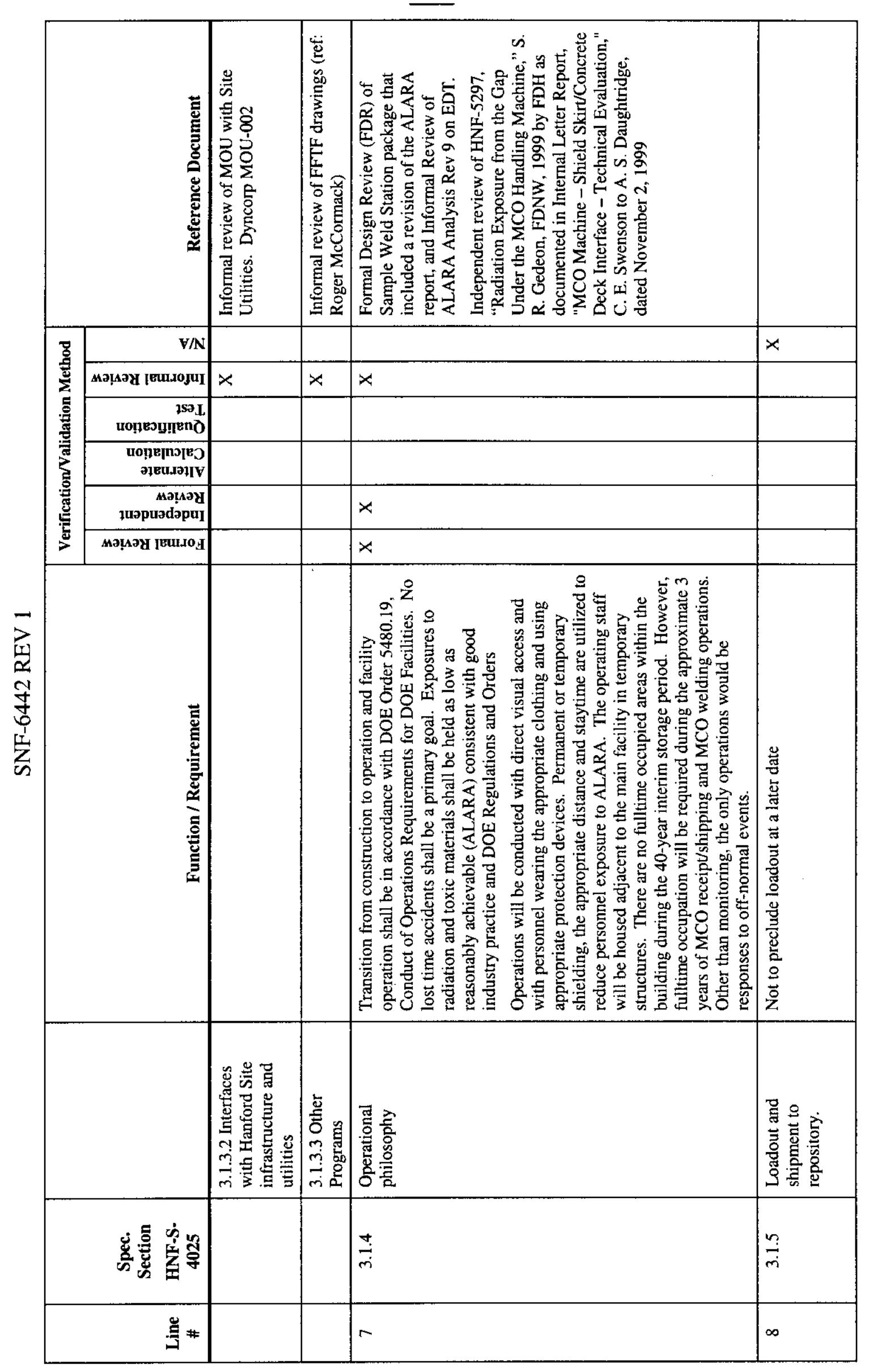




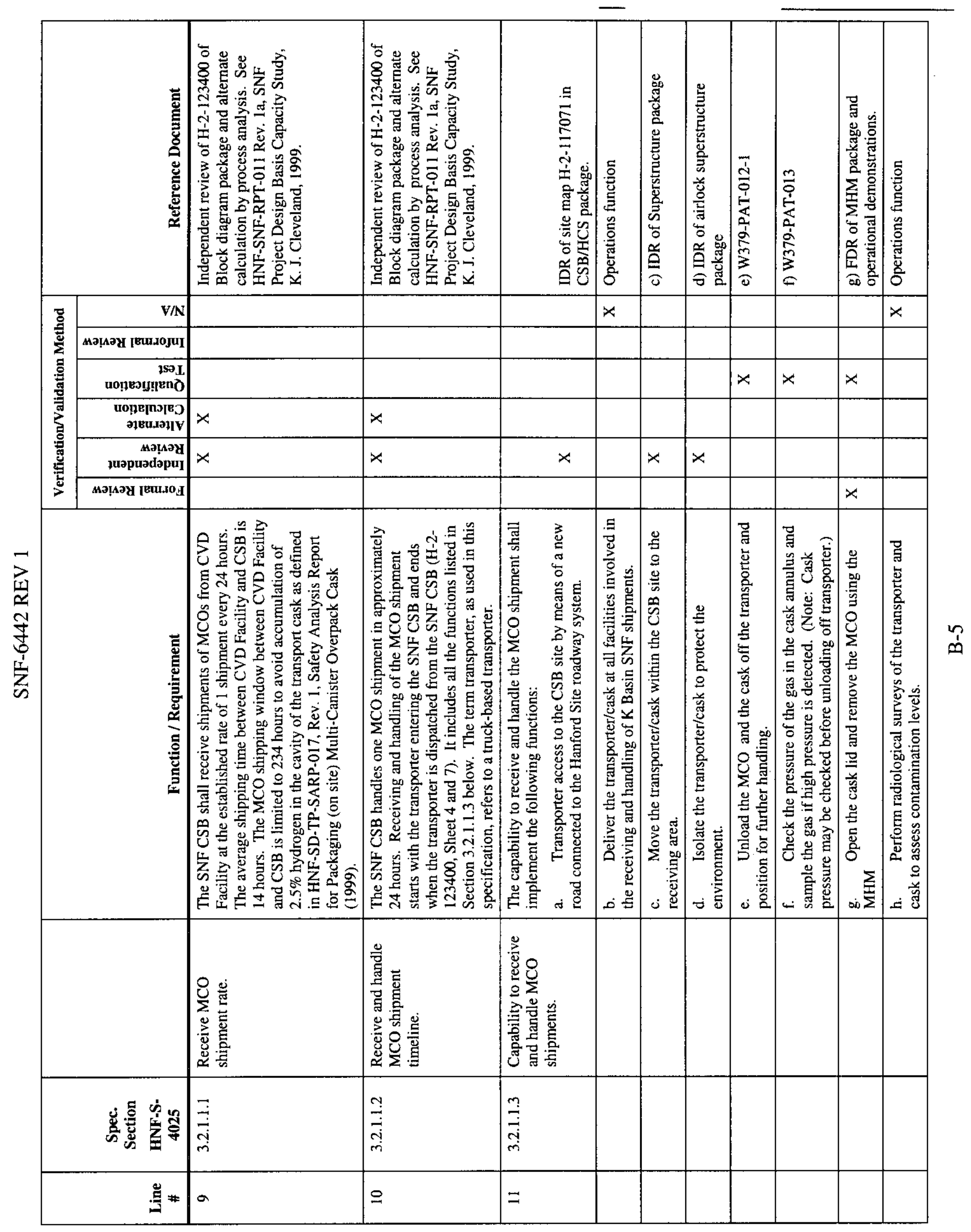




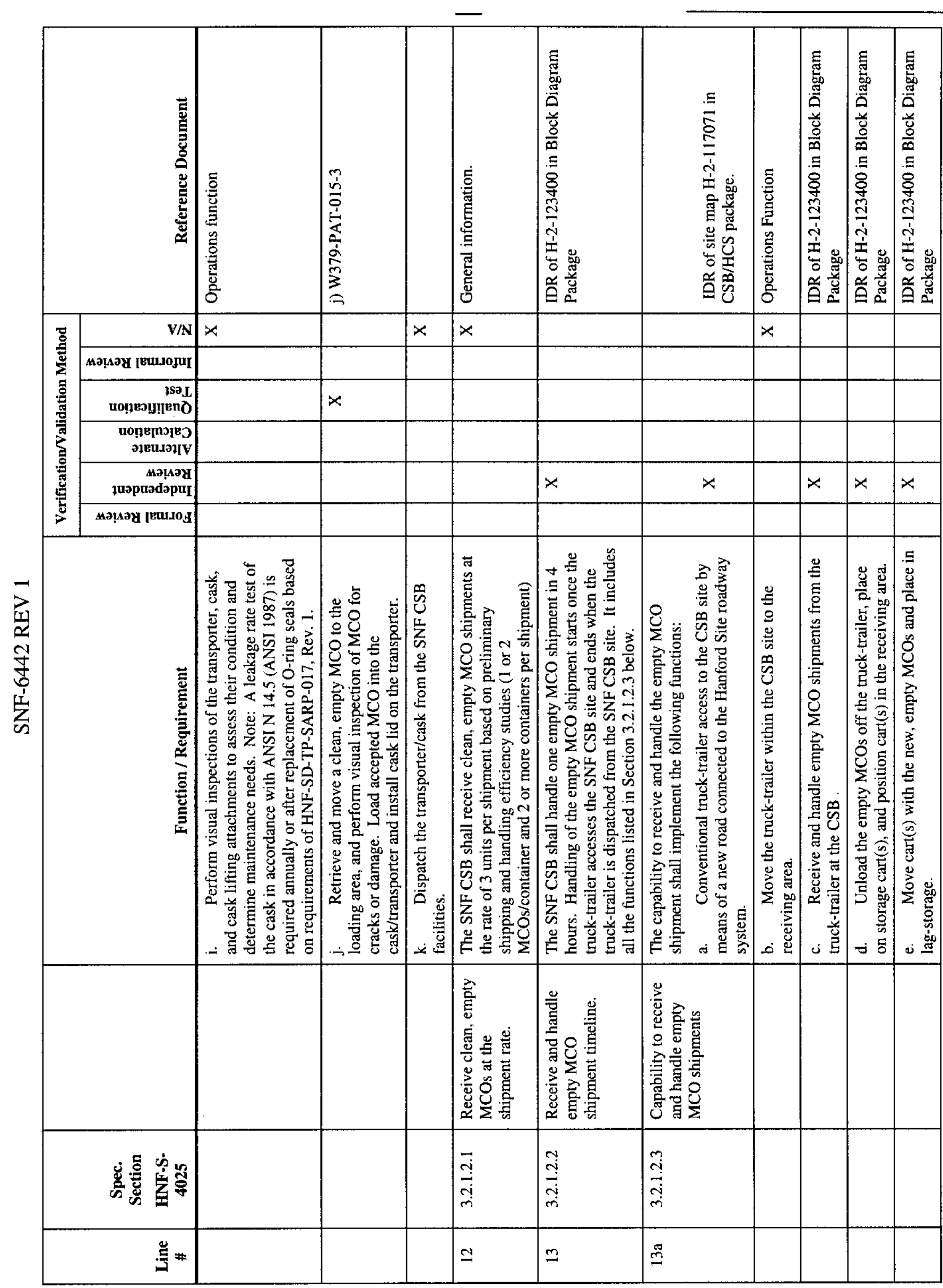




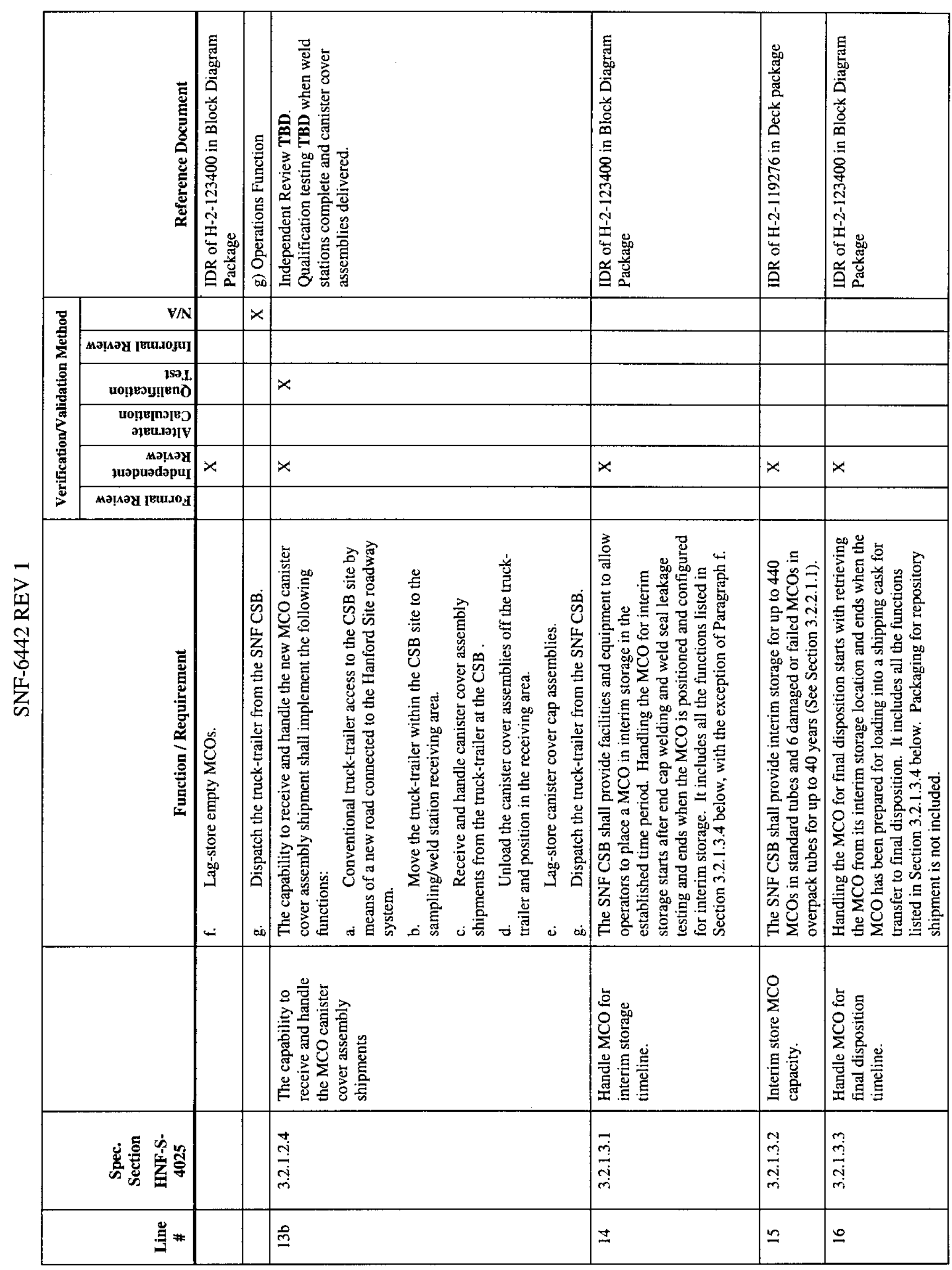

ñ 


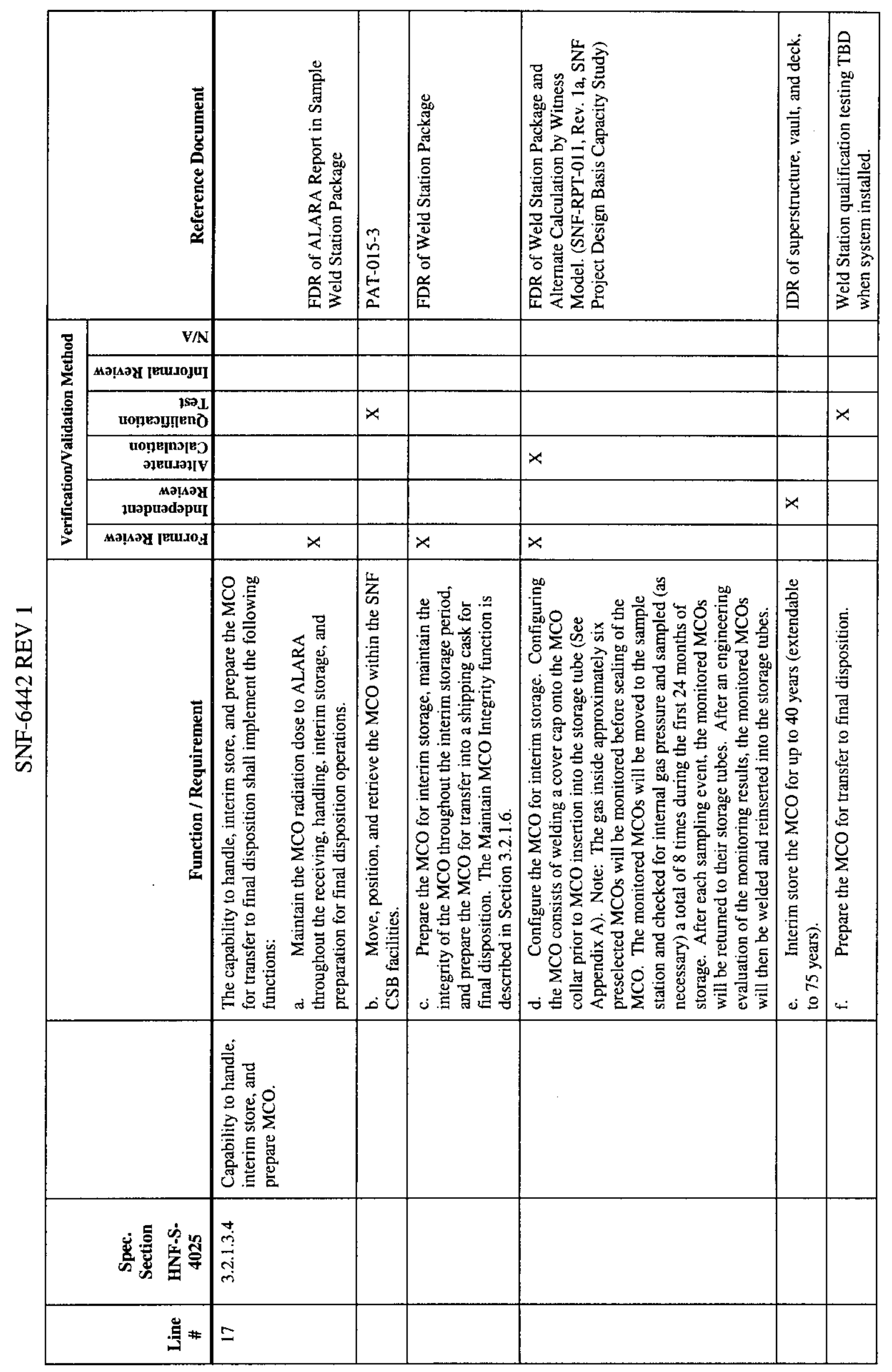




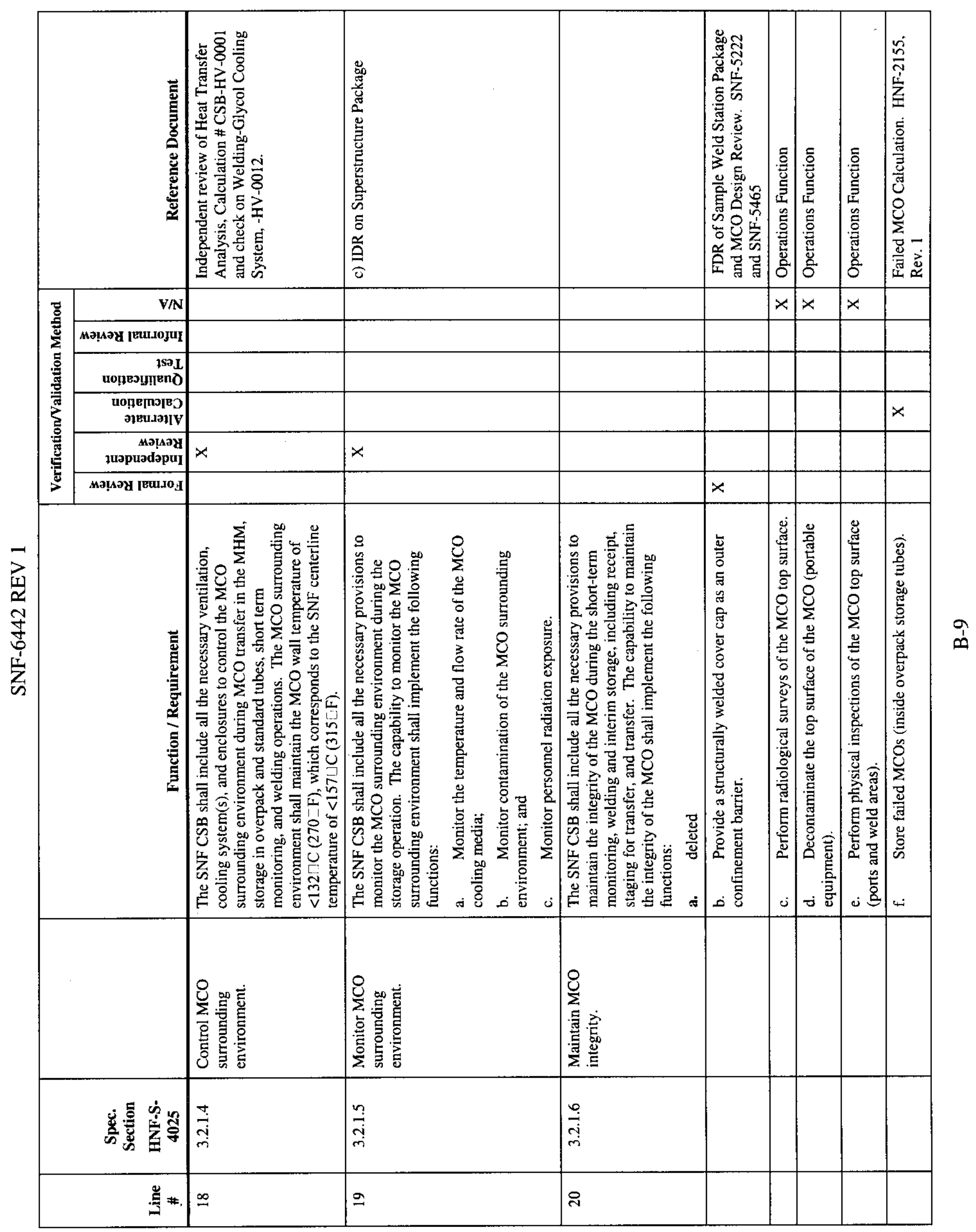




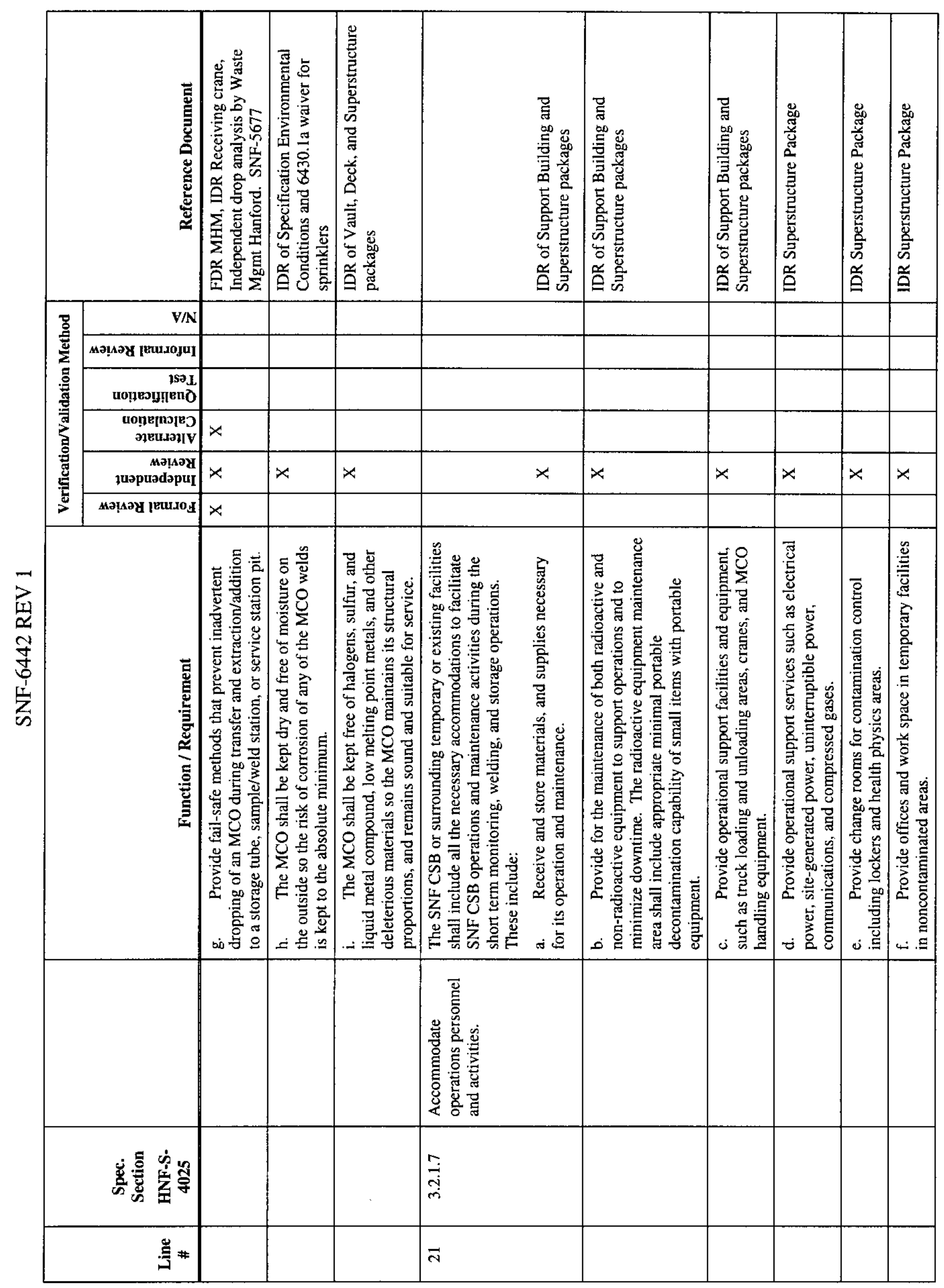




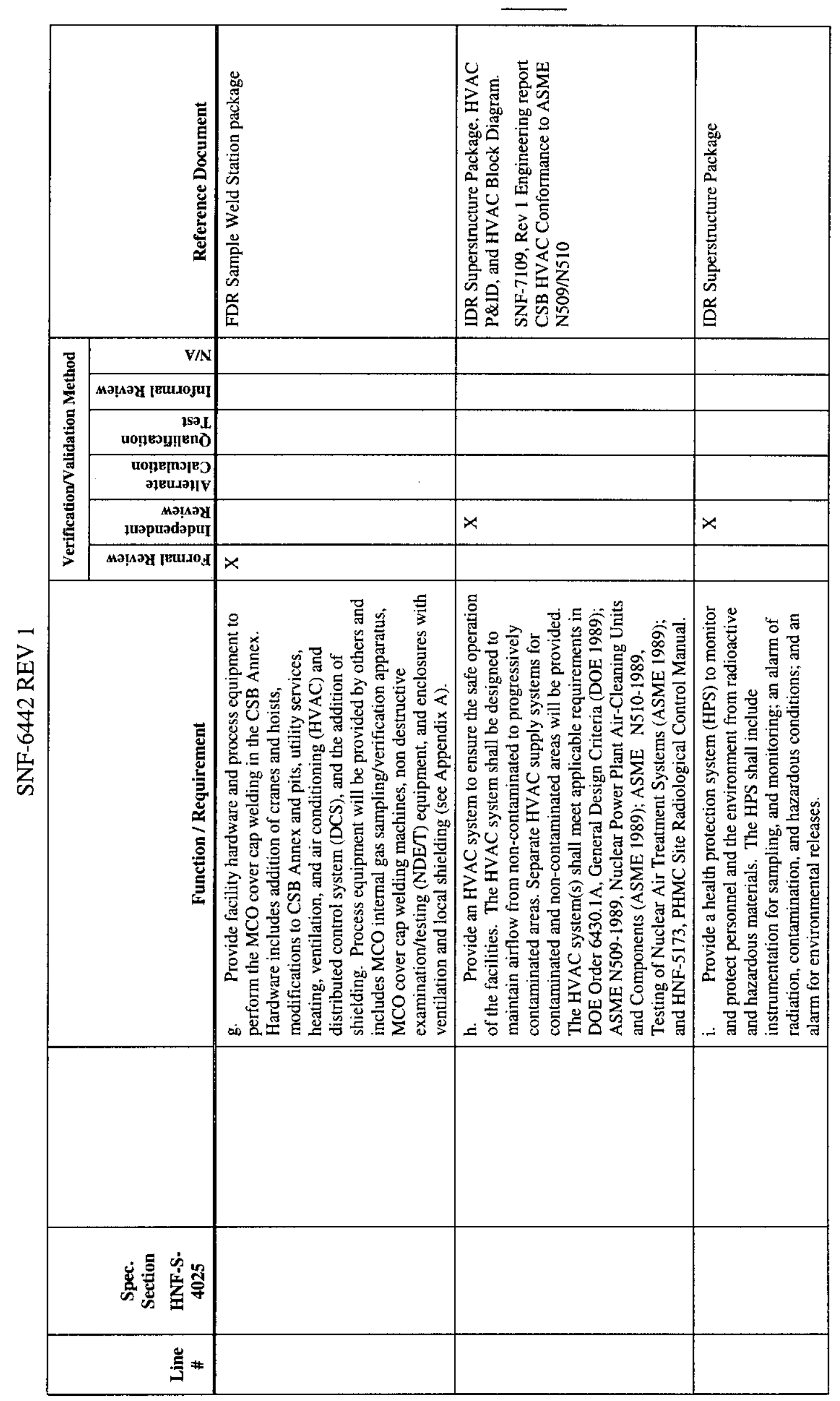




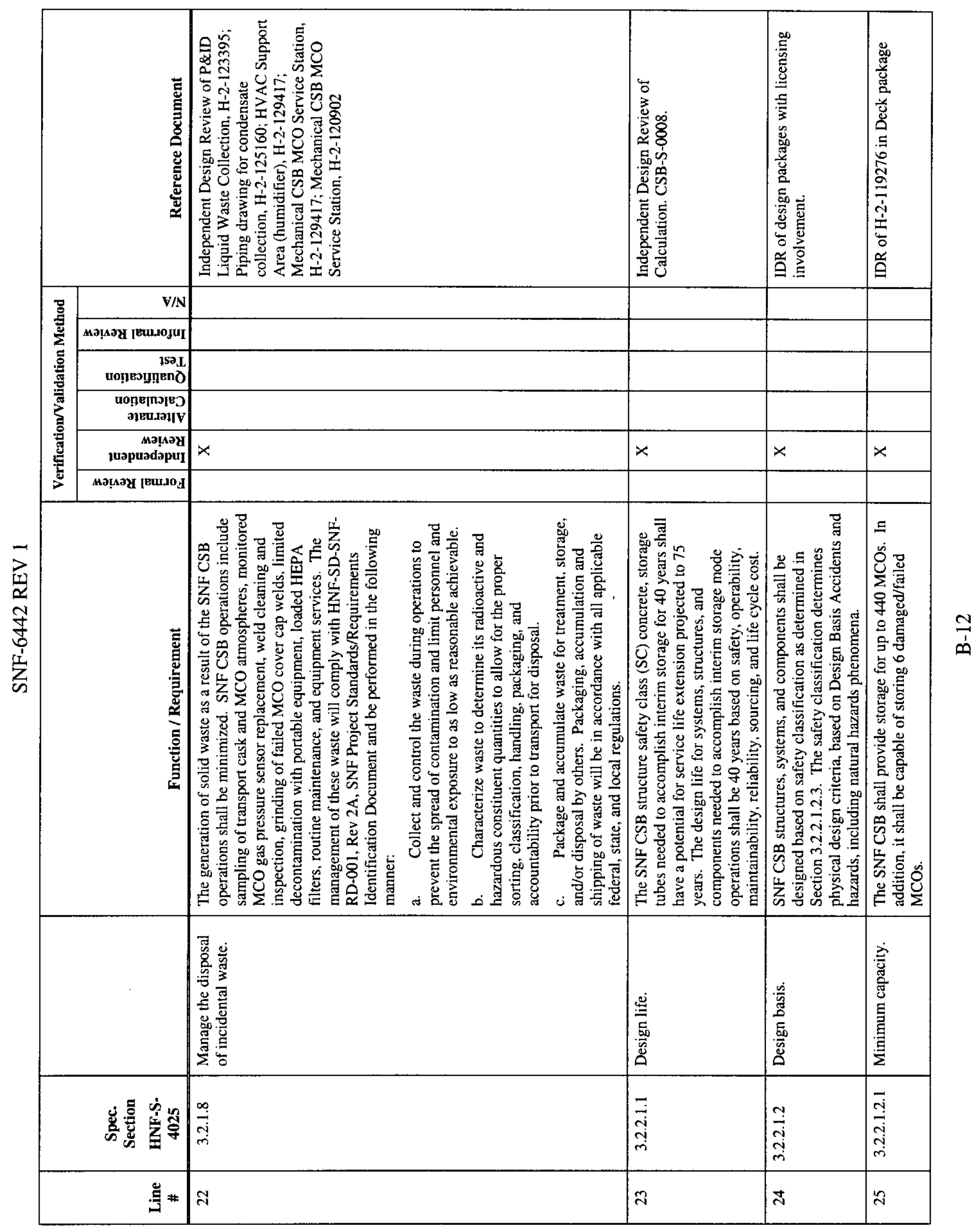




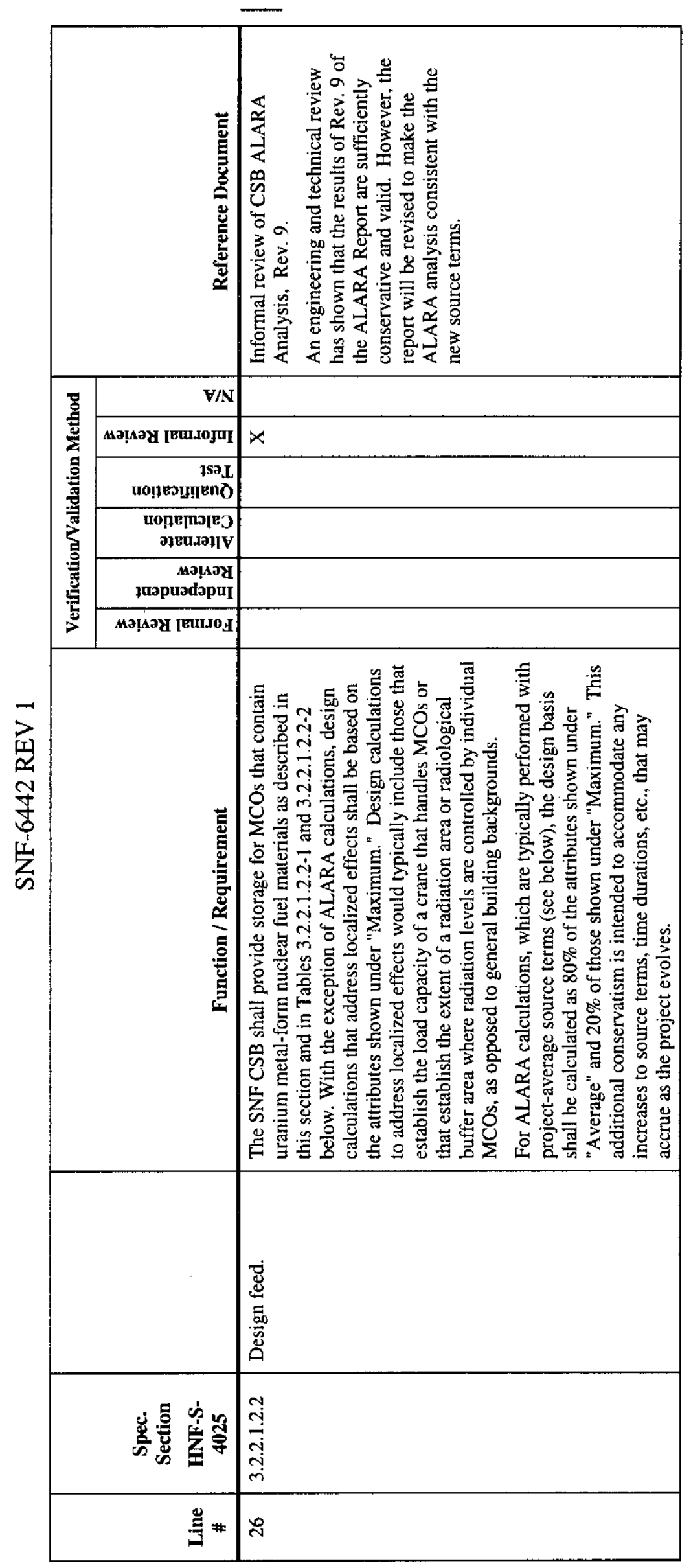

$\stackrel{n}{n}$ 


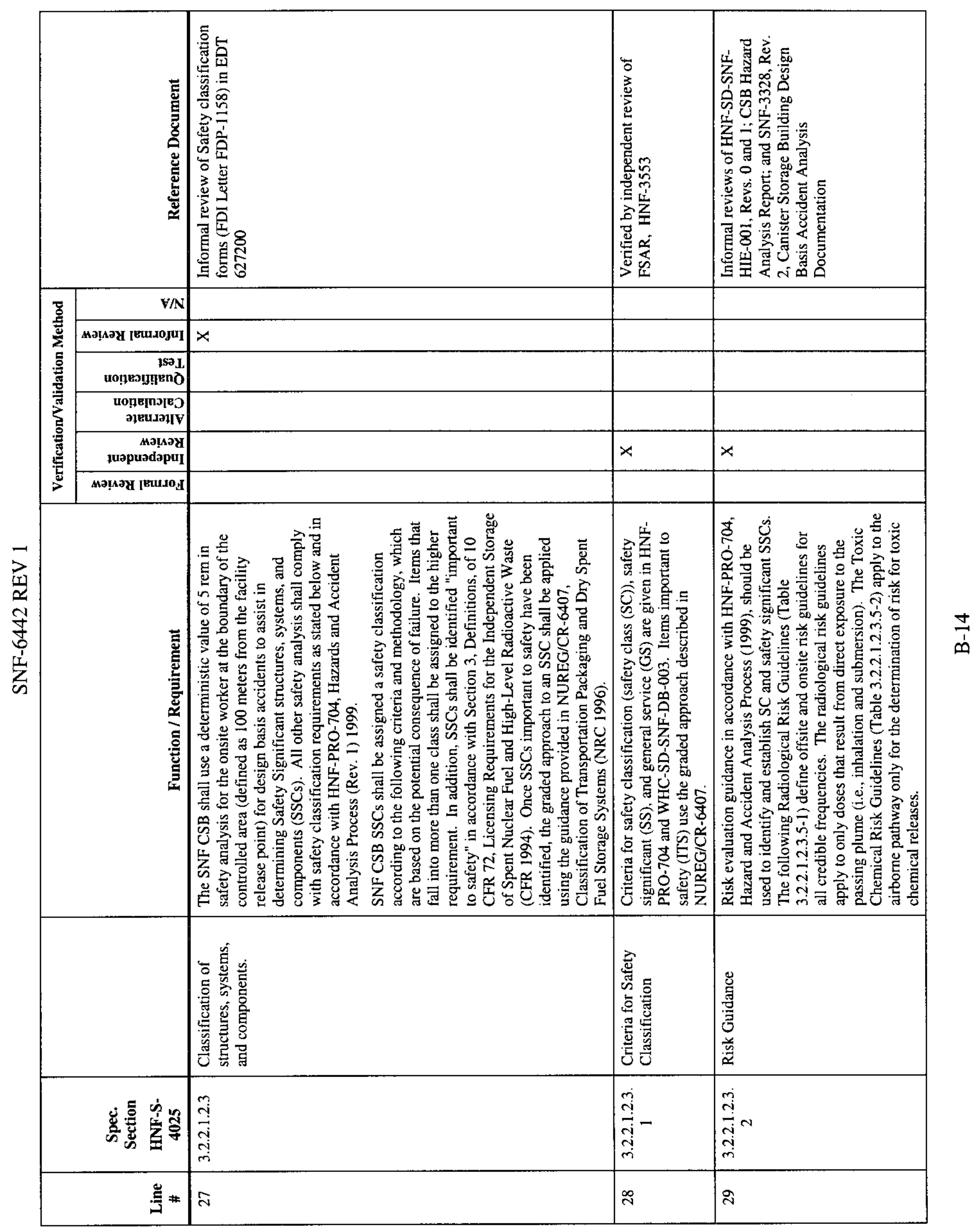




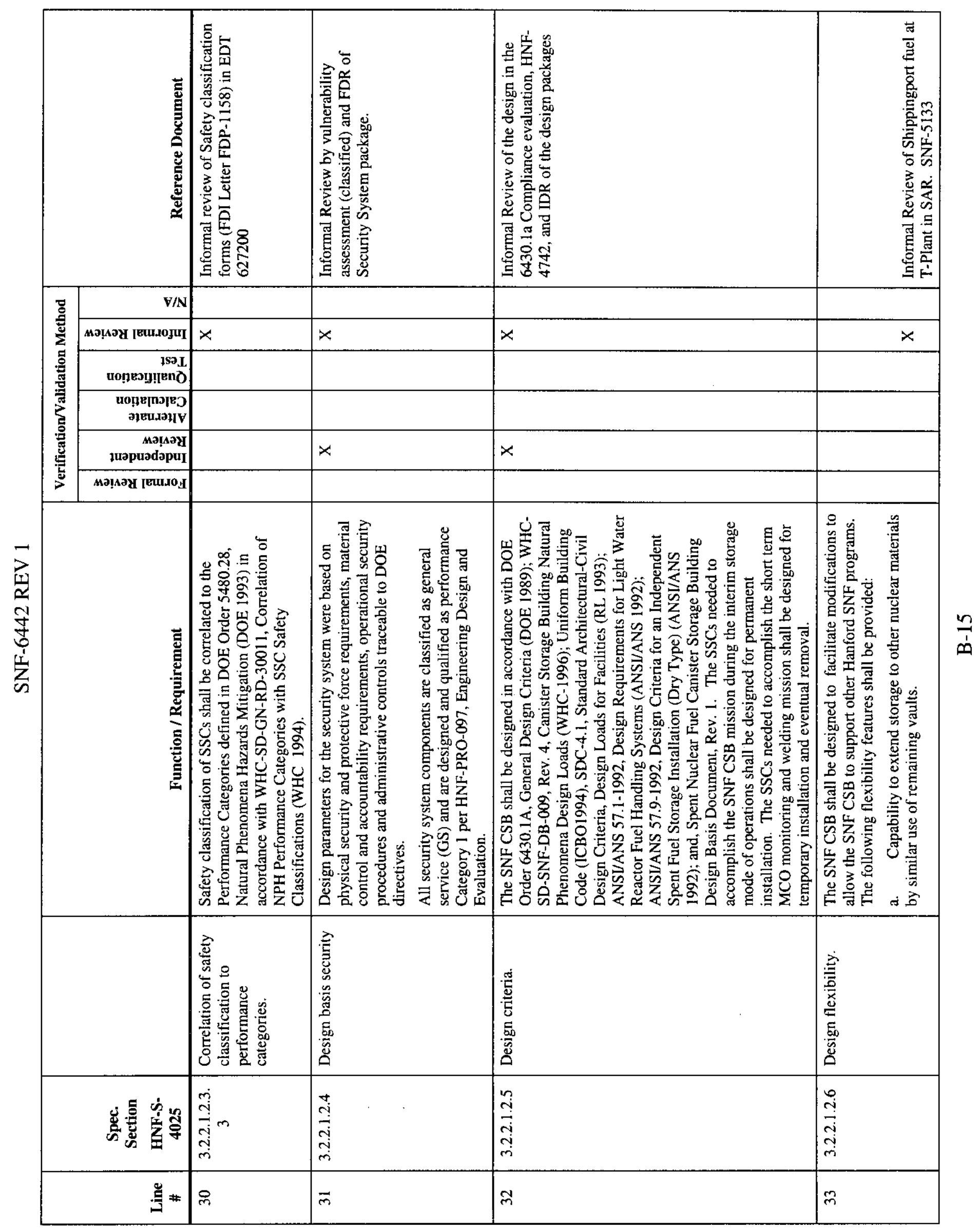




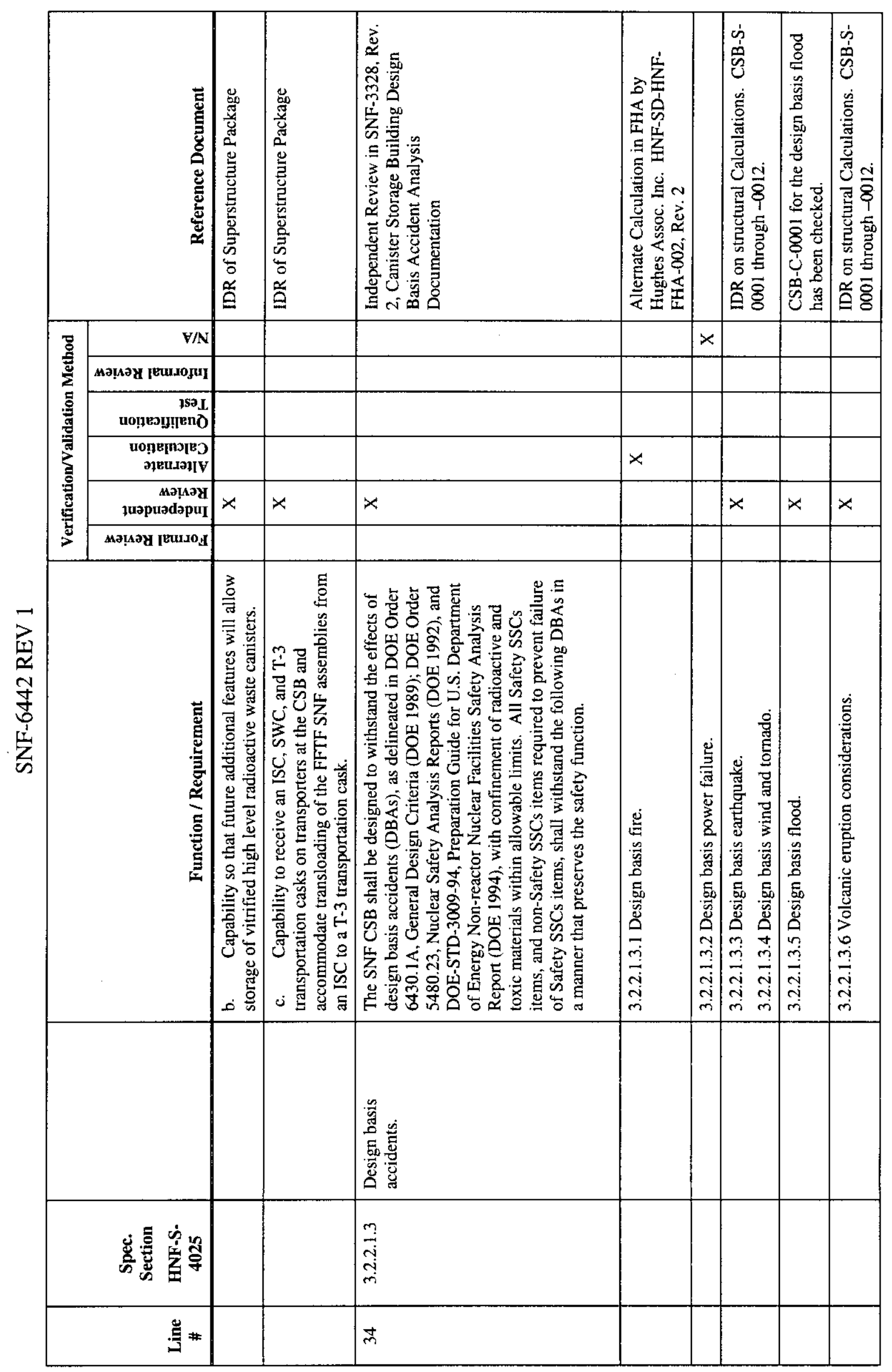




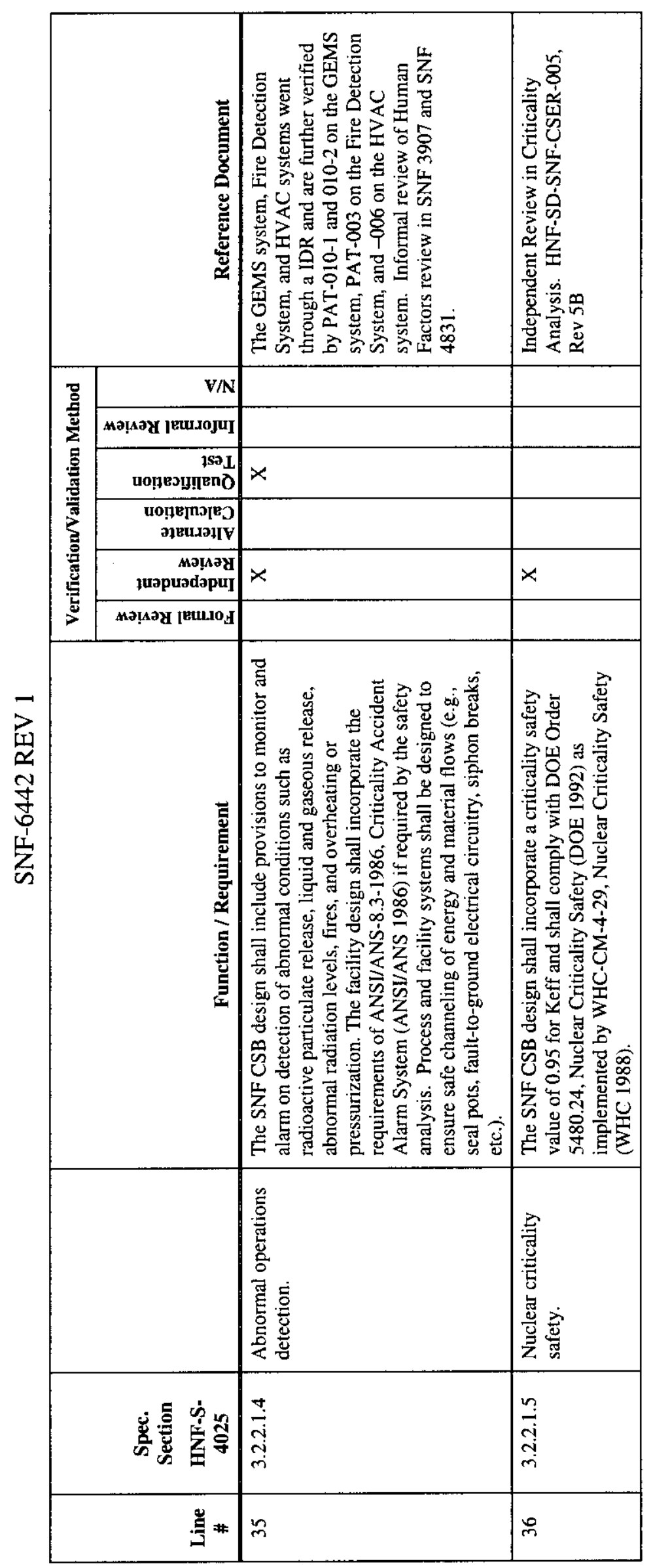

$\frac{1}{9}$ 


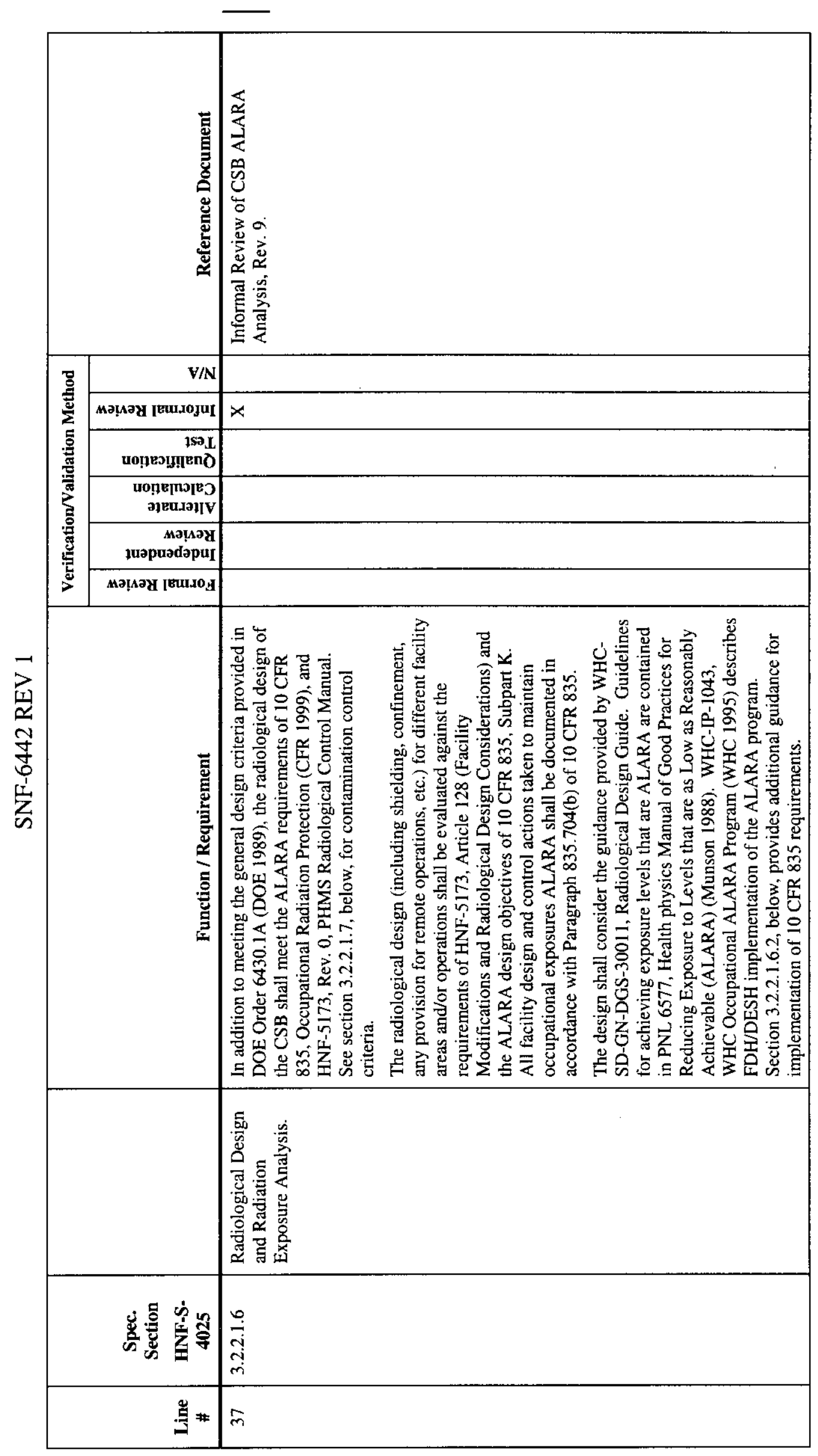

$\frac{\infty}{\infty}$ 


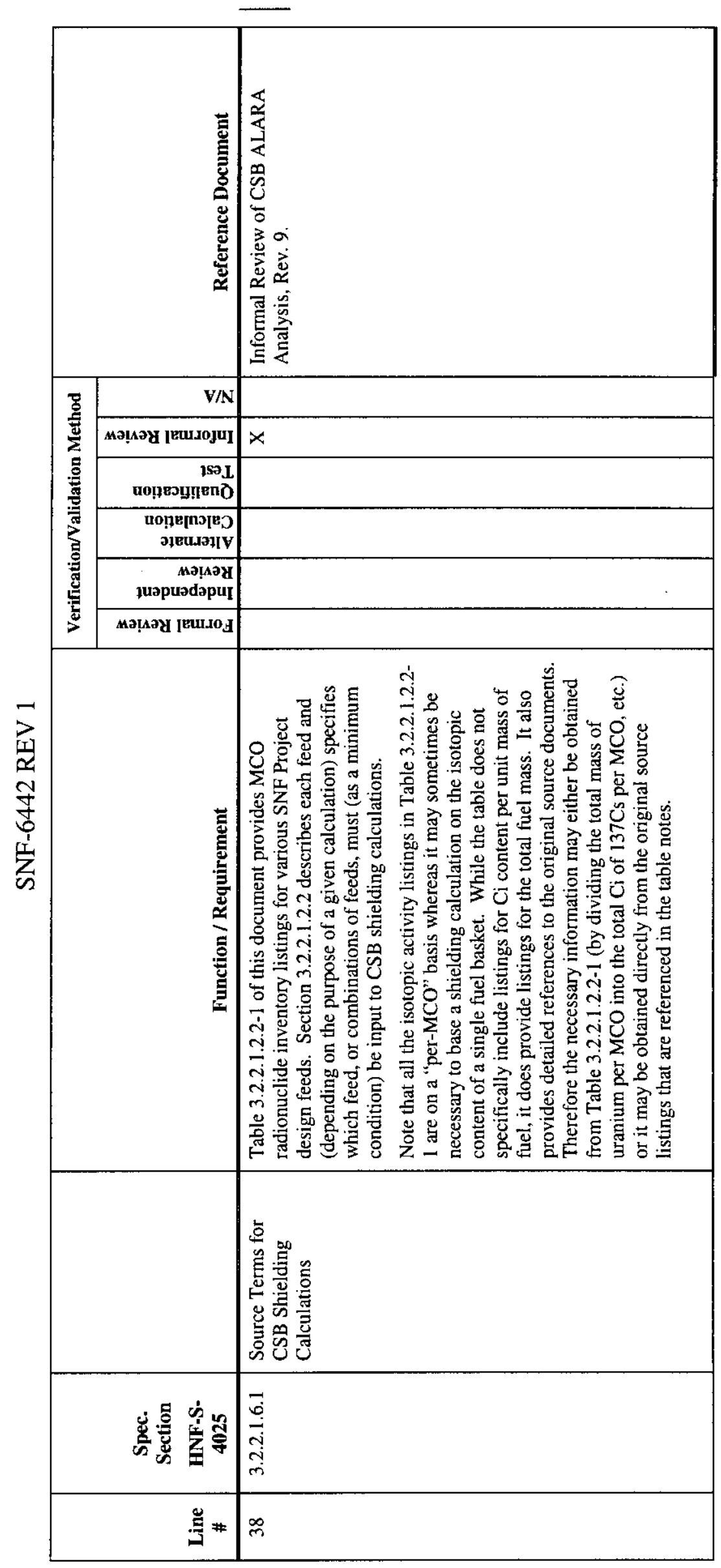

$\frac{a}{\infty}$ 


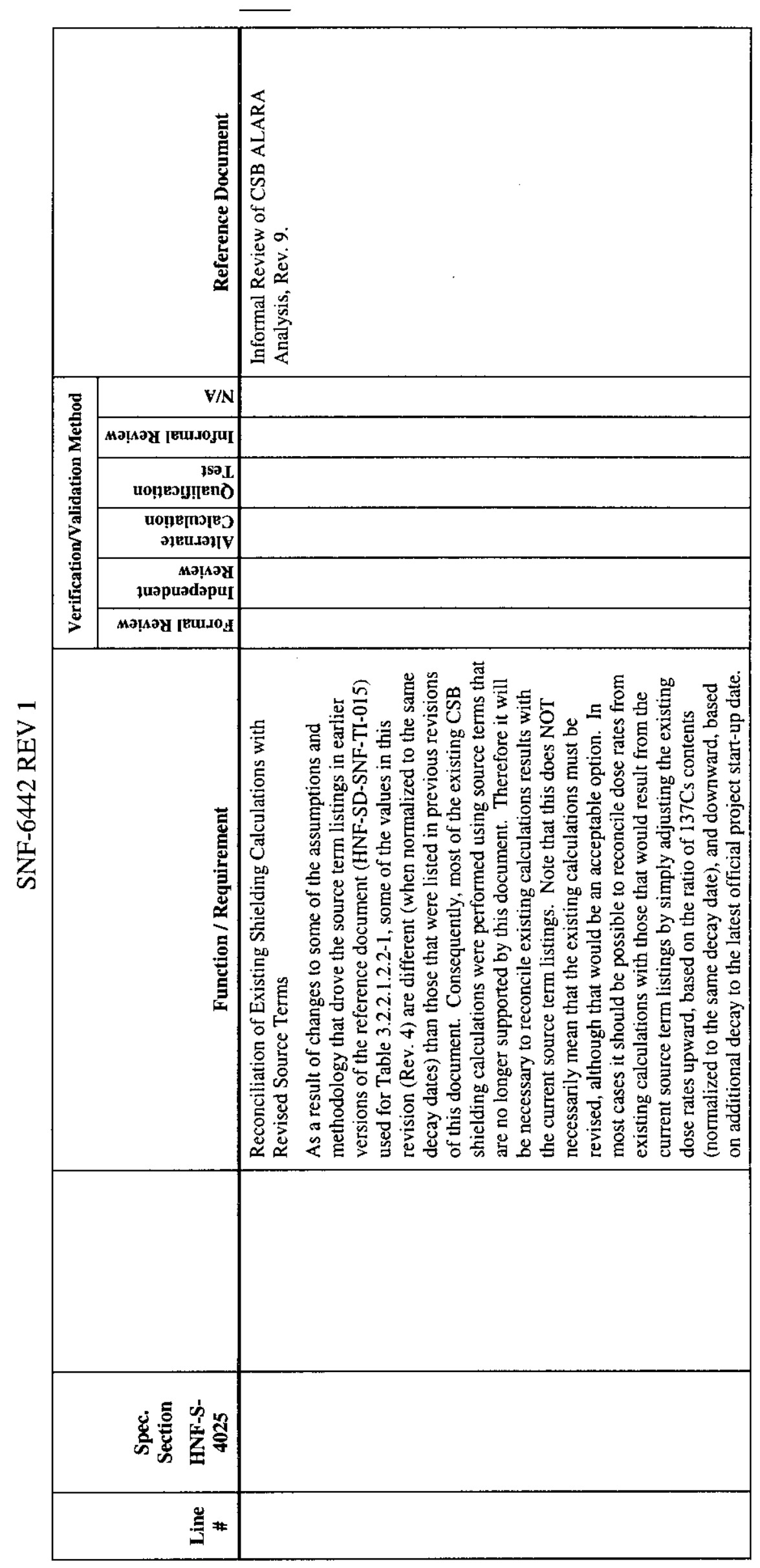

구 


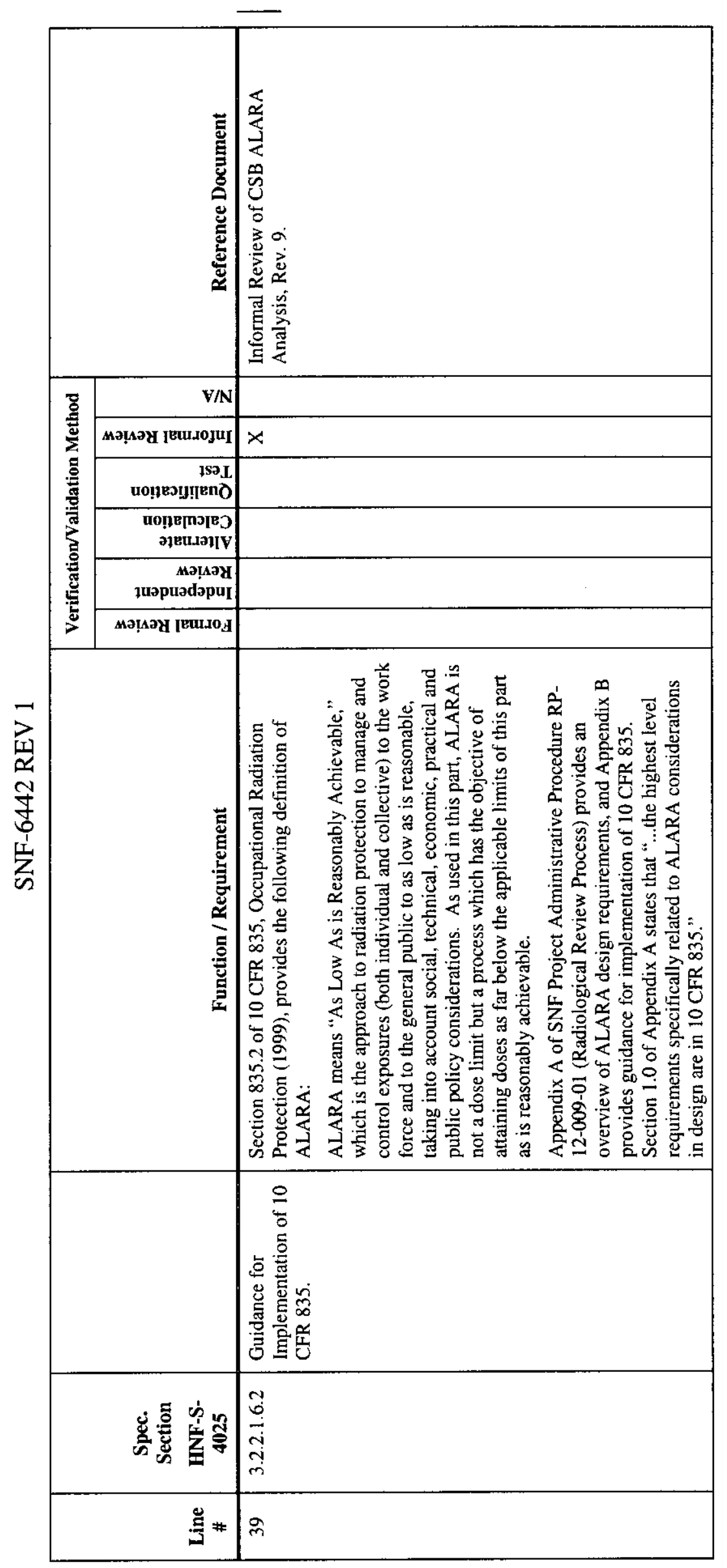




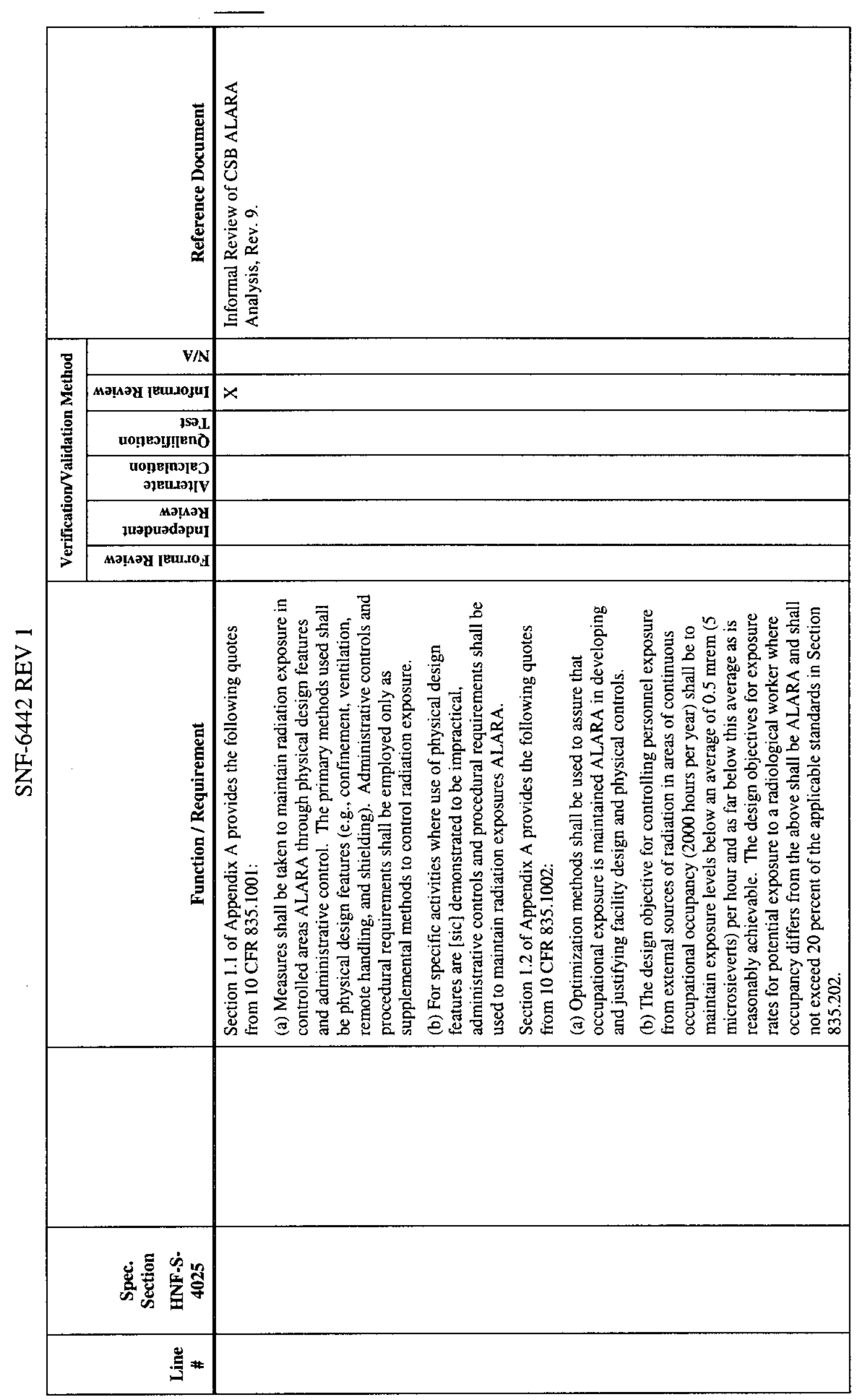

ヘิ 


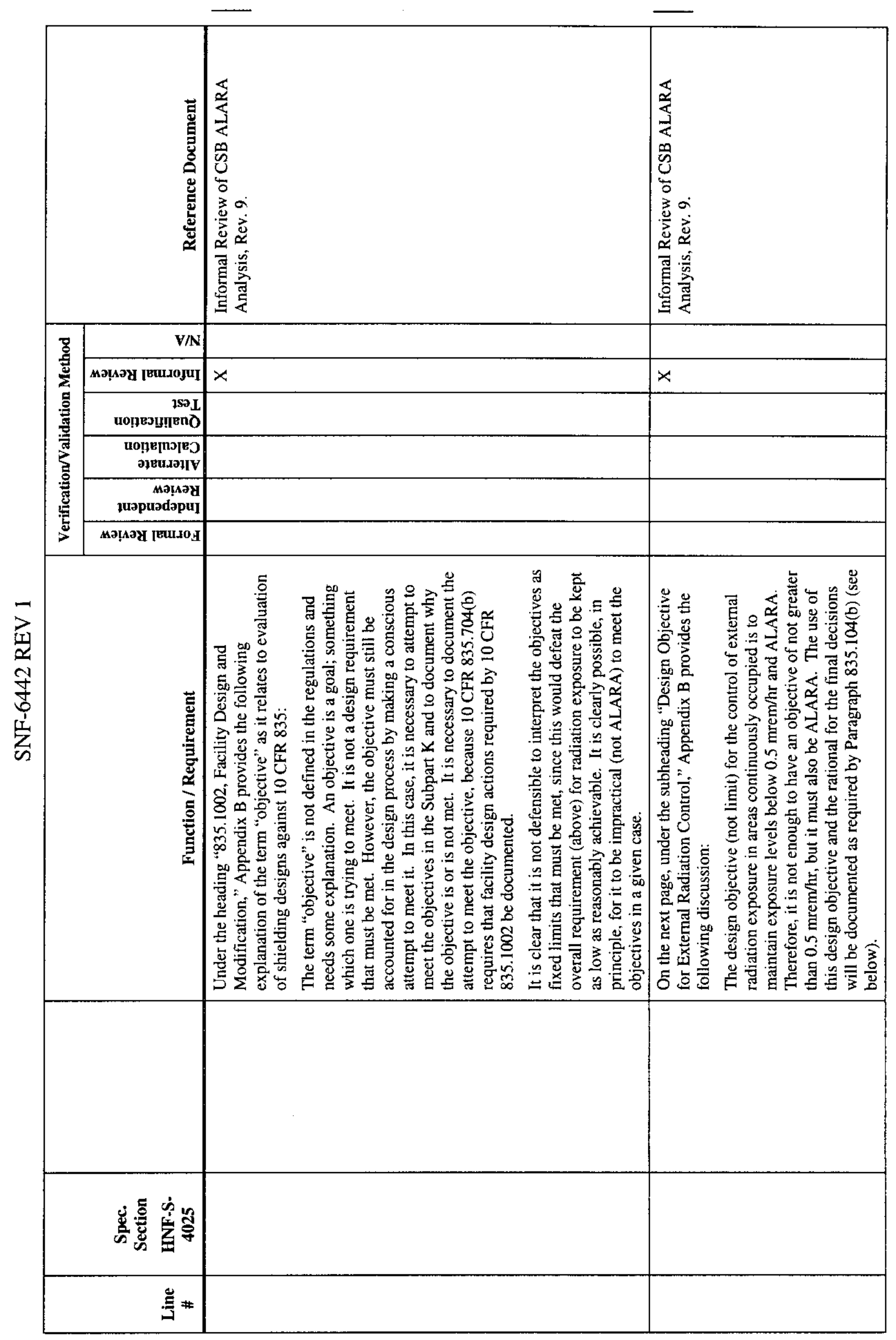

$n$
1
$\infty$ 


\begin{tabular}{|c|c|c|c|c|c|}
\hline & 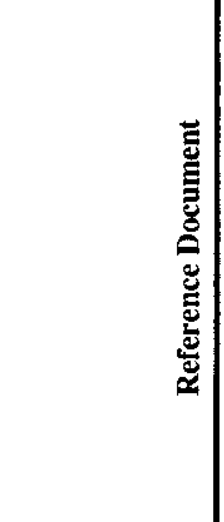 & 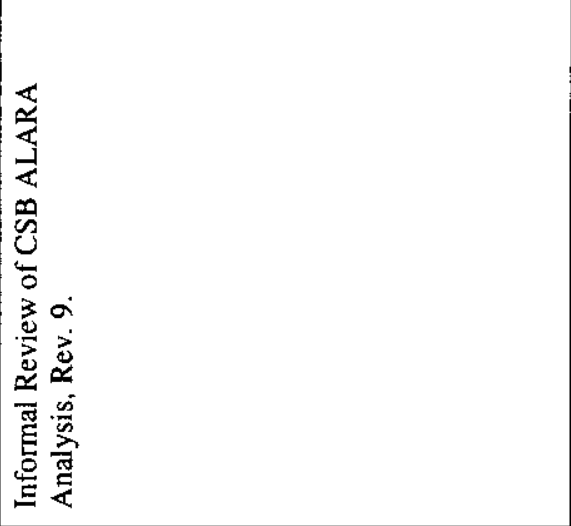 & 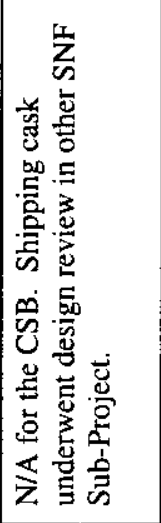 & 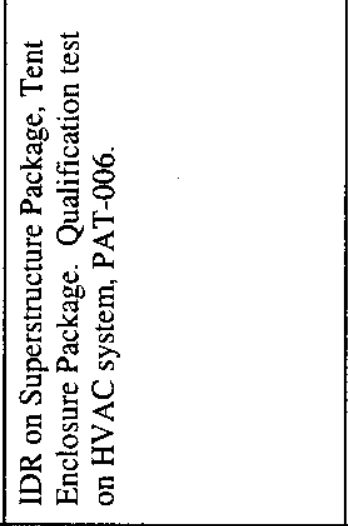 & 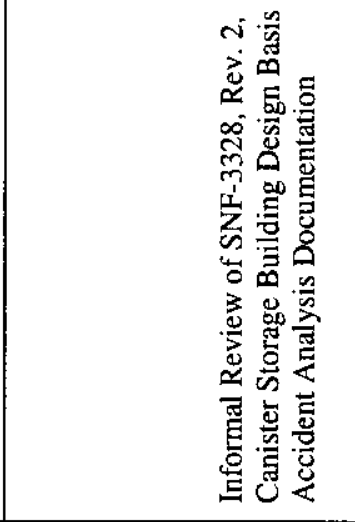 \\
\hline \multirow{6}{*}{ 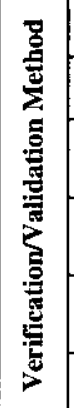 } & $\mathbf{v} / \mathbf{N}$ & & $x$ & & \\
\hline & мәчмәу Іешиолич & $x$ & & & $x$ \\
\hline & 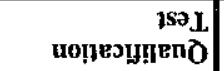 & & & $x$ & \\
\hline & 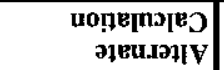 & & & & \\
\hline & 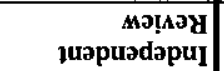 & & & $x$ & \\
\hline & 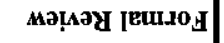 & & & & \\
\hline \multirow{2}{*}{\multicolumn{2}{|c|}{ 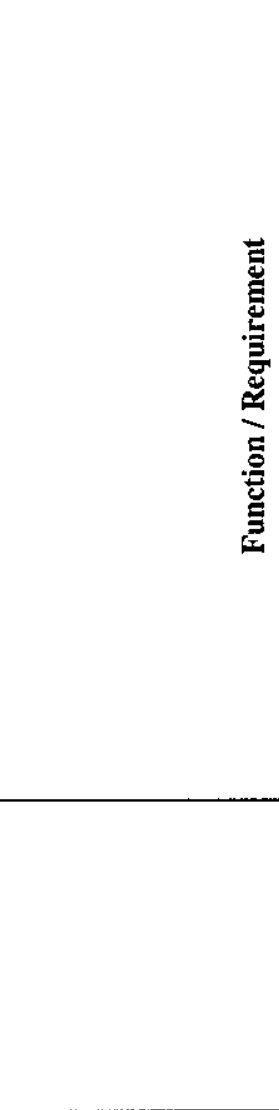 }} & 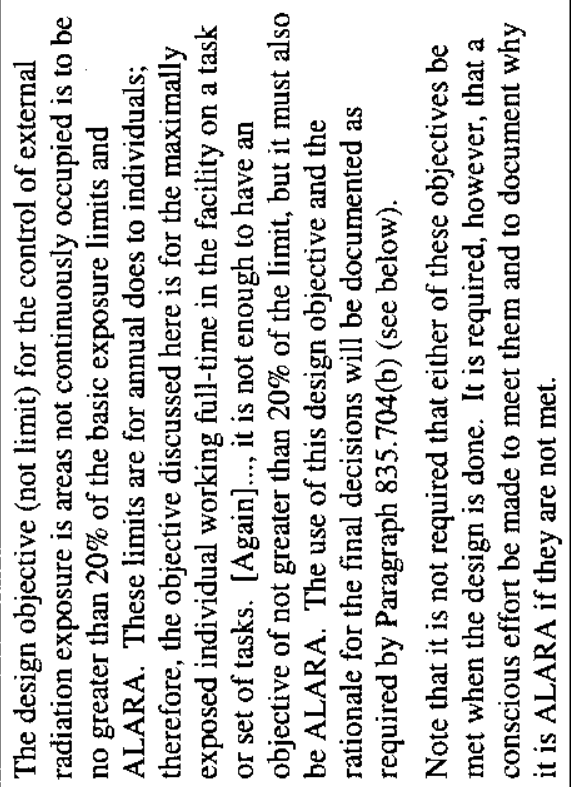 & 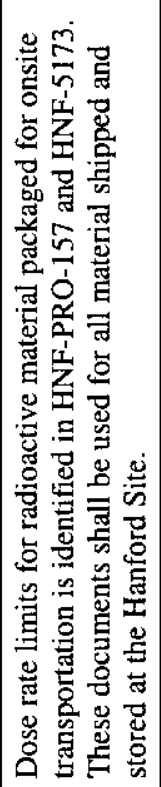 & 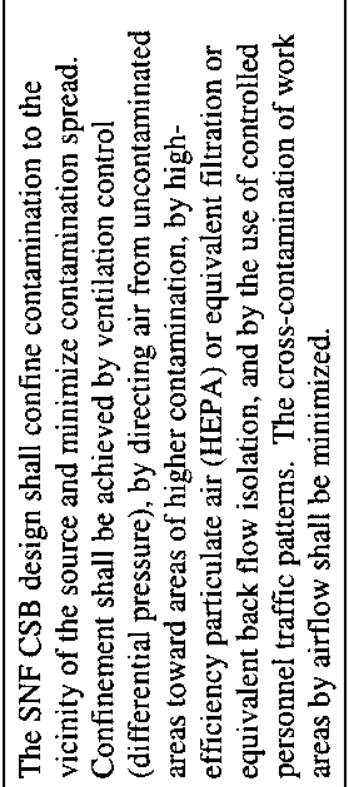 & 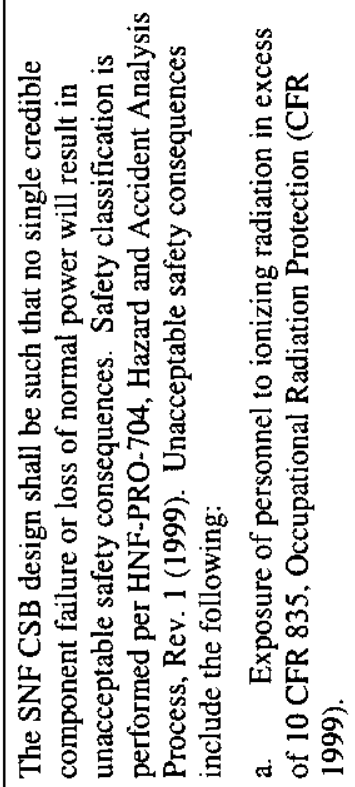 \\
\hline & & & 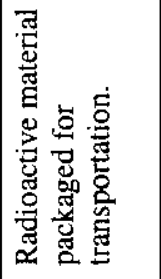 & 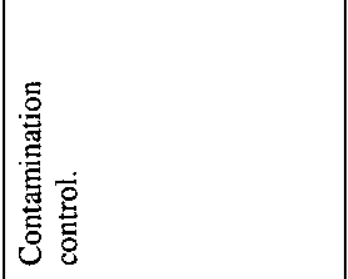 & 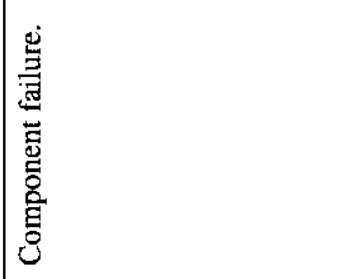 \\
\hline & 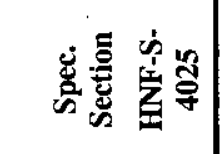 & & 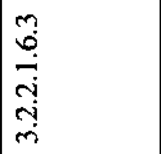 & 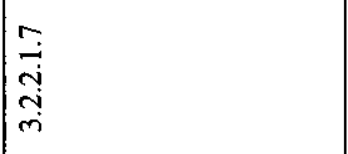 & 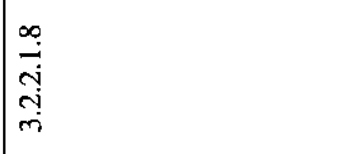 \\
\hline & $\stackrel{\Xi}{\Xi}$ & & \& & $F$ & $\mathcal{y}$ \\
\hline
\end{tabular}




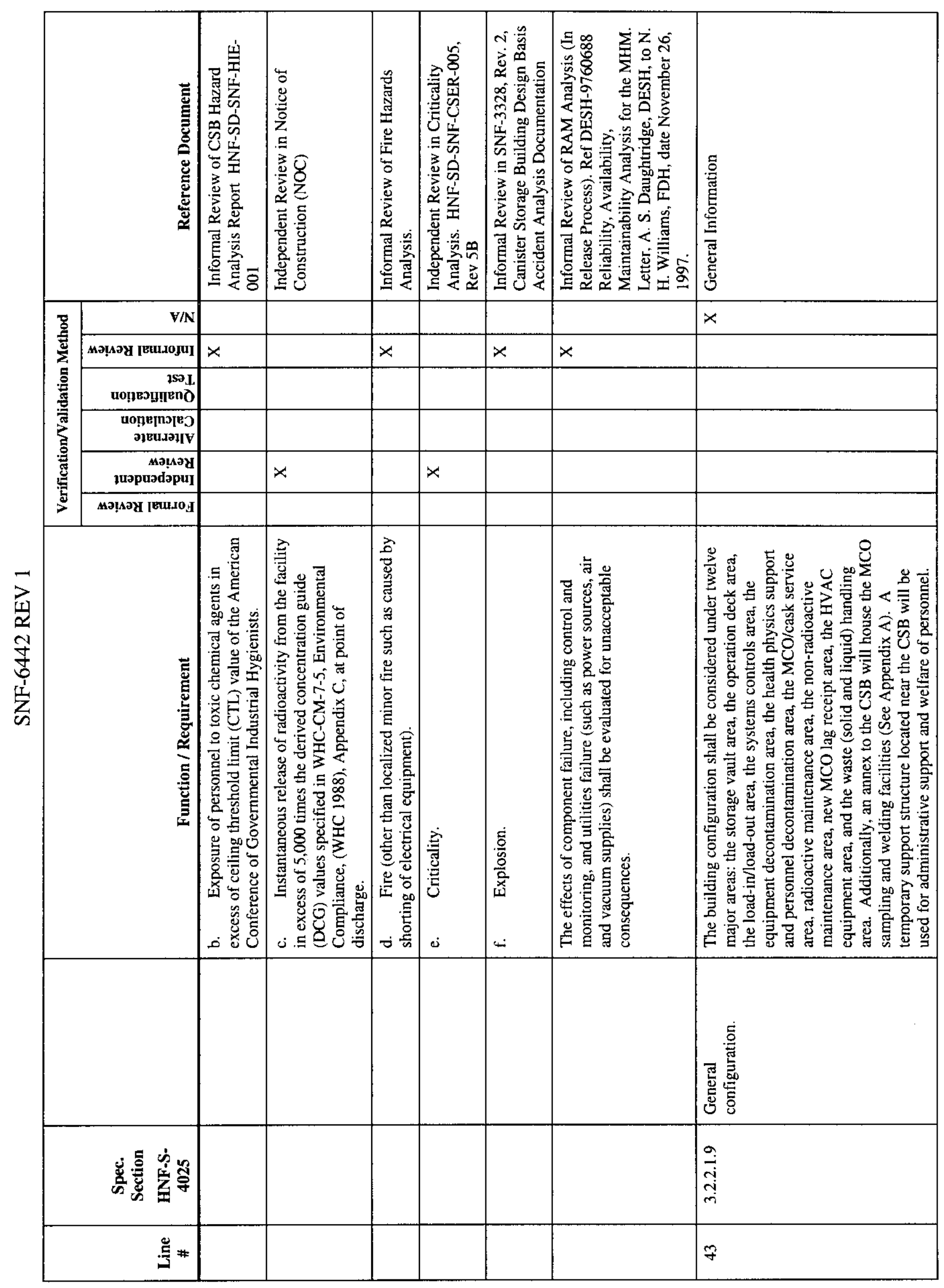




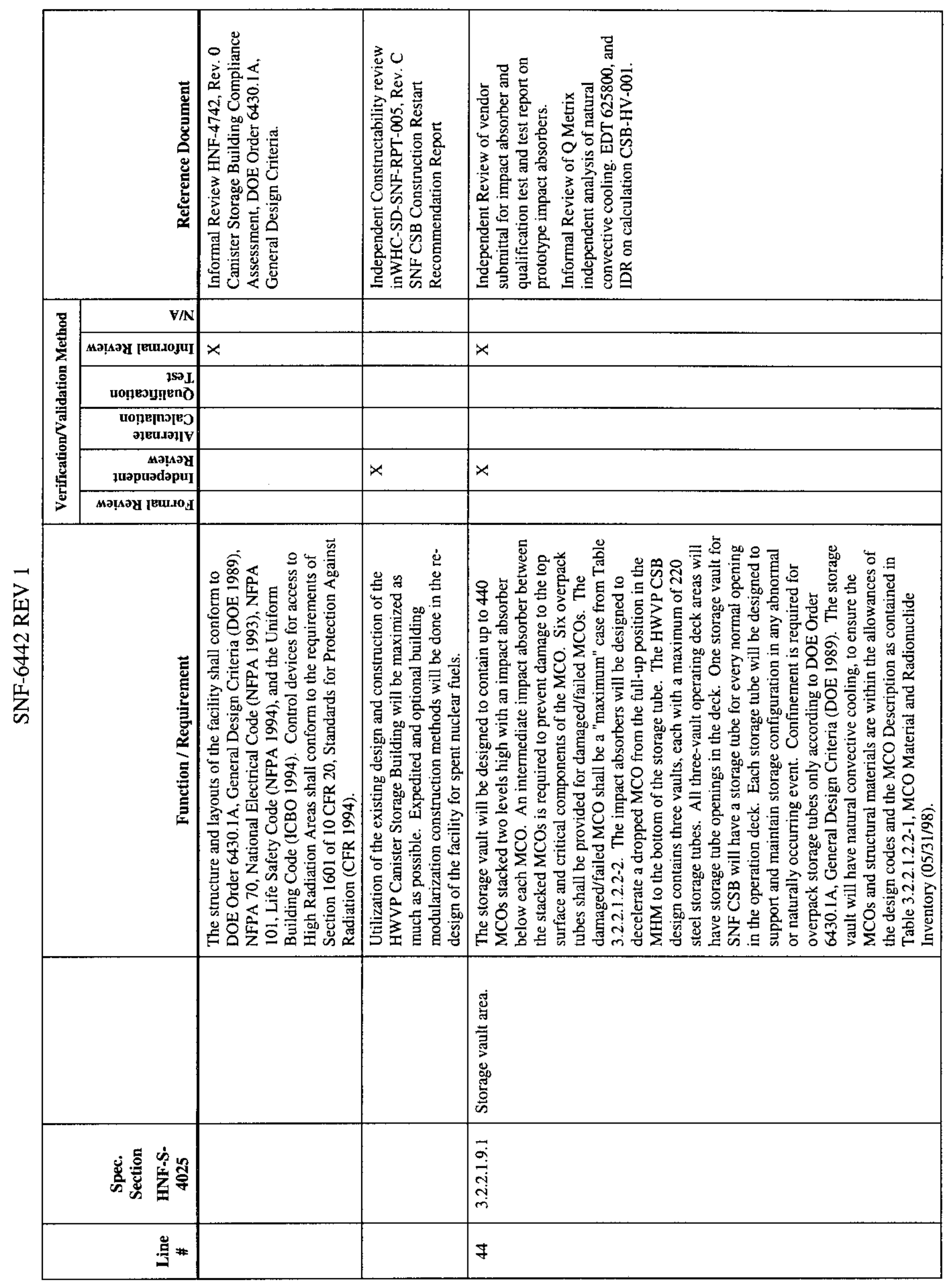




\begin{tabular}{|c|c|c|c|c|c|}
\hline \multicolumn{2}{|c|}{ |气 } & 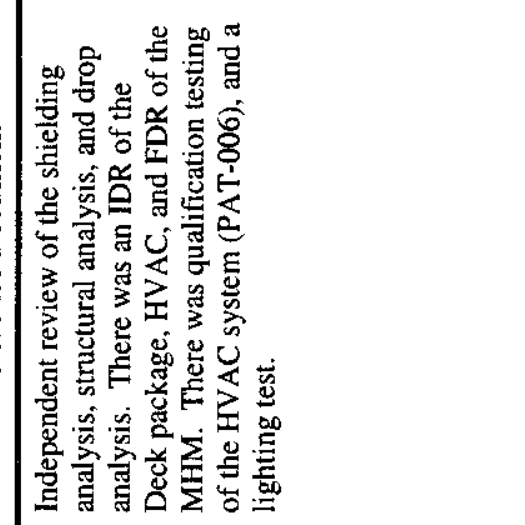 & 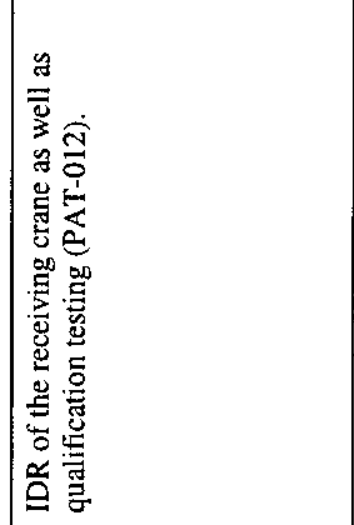 & 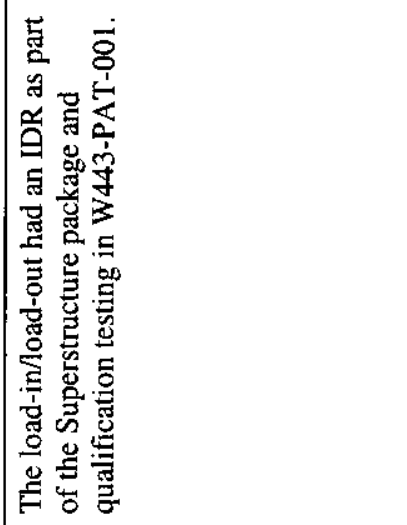 & 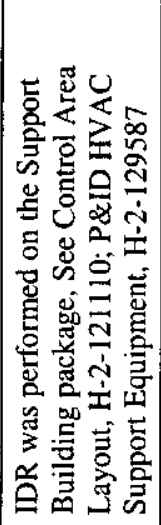 \\
\hline \multirow{6}{*}{ 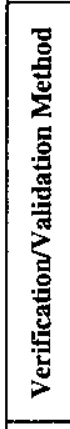 } & & & & & \\
\hline & 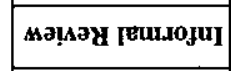 & & & & \\
\hline & 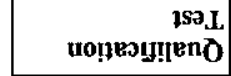 & $x$ & $x$ & $x$ & \\
\hline & 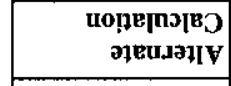 & & & & \\
\hline & 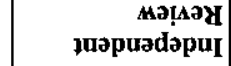 & $x$ & $\times$ & $x$ & $\times$ \\
\hline & 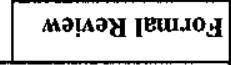 & $x$ & & & \\
\hline & |: & 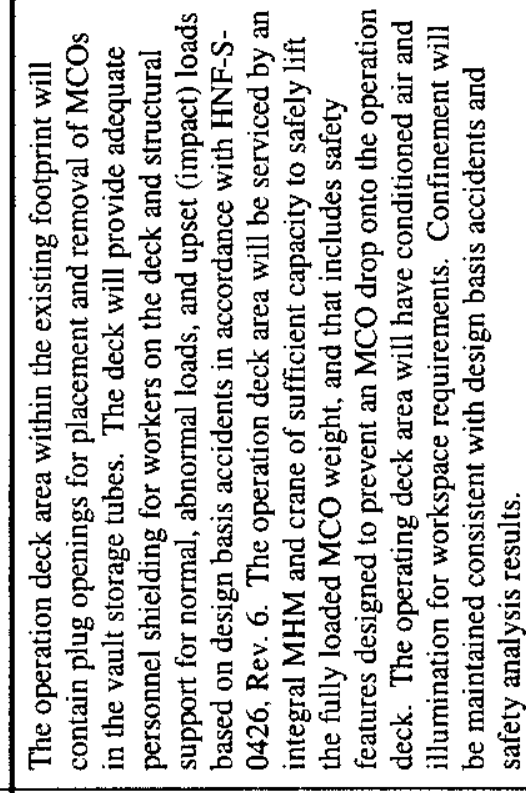 & 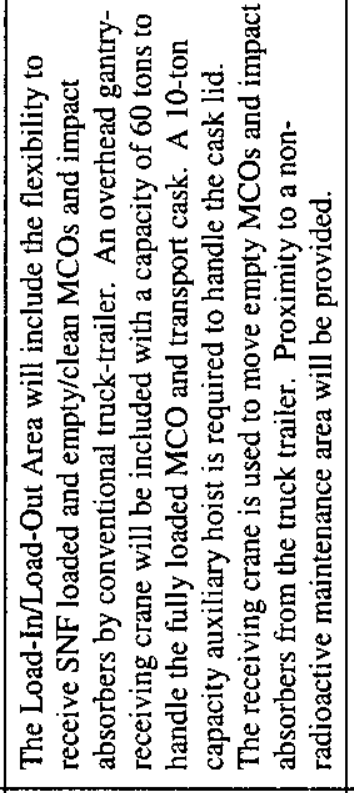 & 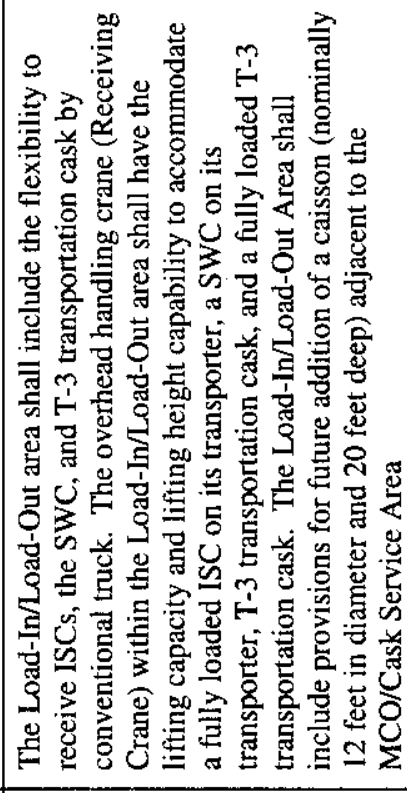 & 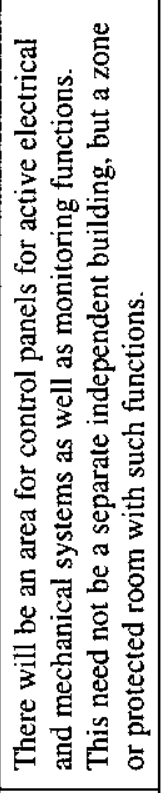 \\
\hline & & 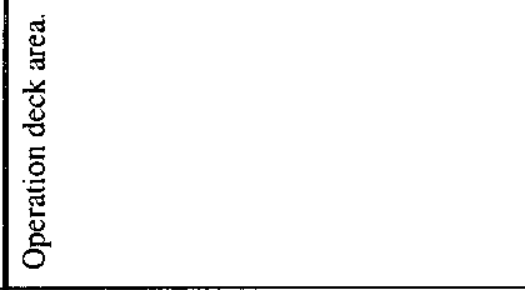 & 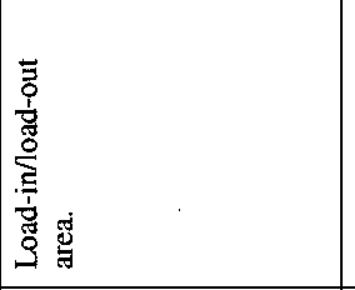 & & 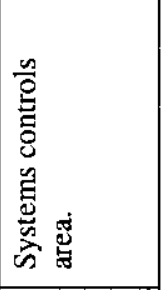 \\
\hline & 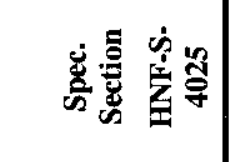 & $\mid$ & 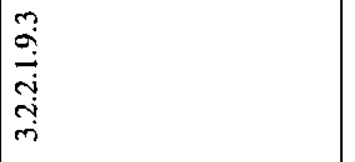 & & 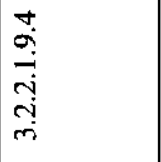 \\
\hline & 总来 & 8 & i & & a \\
\hline
\end{tabular}




\begin{tabular}{|c|c|c|c|}
\hline 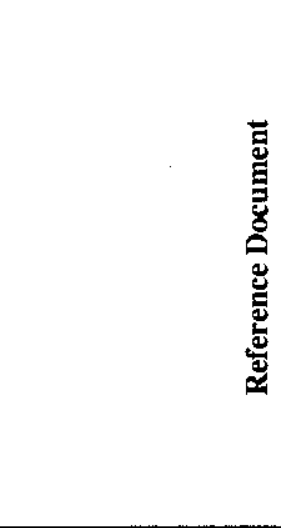 & 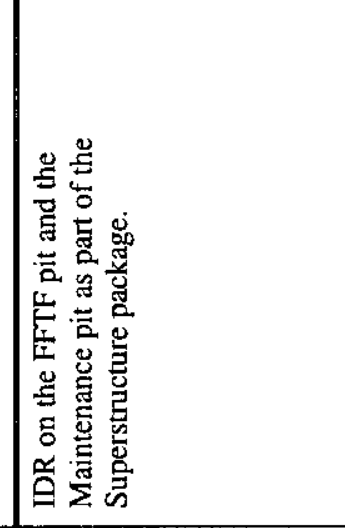 & 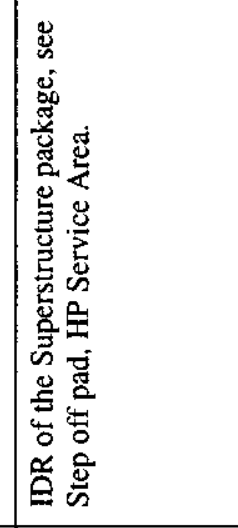 & 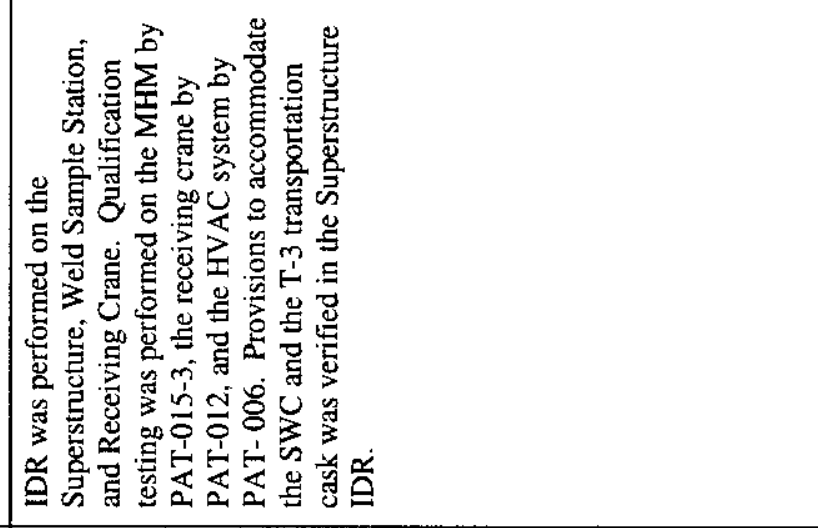 \\
\hline $\mathrm{VN}$ & & & \\
\hline 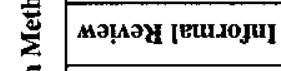 & & & \\
\hline 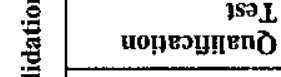 & & & $x$ \\
\hline 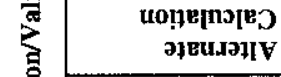 & & & \\
\hline 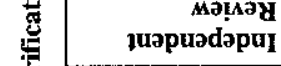 & $x$ & $x$ & $x$ \\
\hline 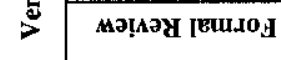 & & & \\
\hline \multirow[t]{2}{*}{ 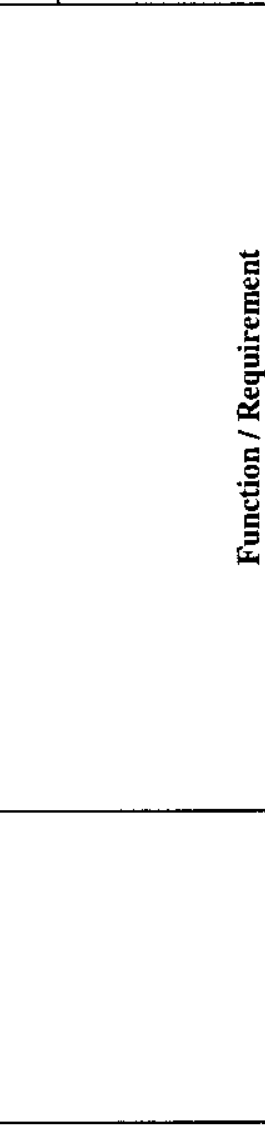 } & 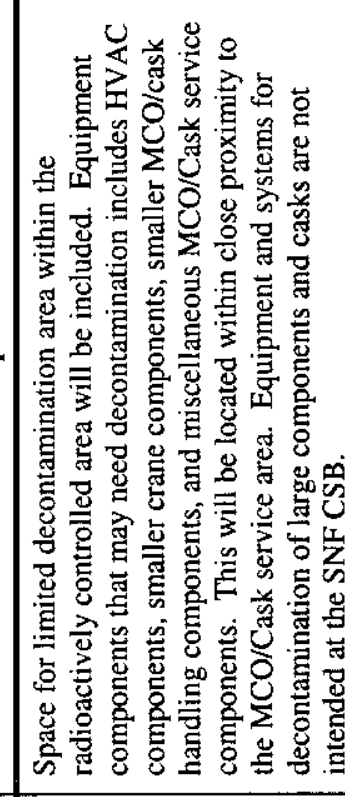 & 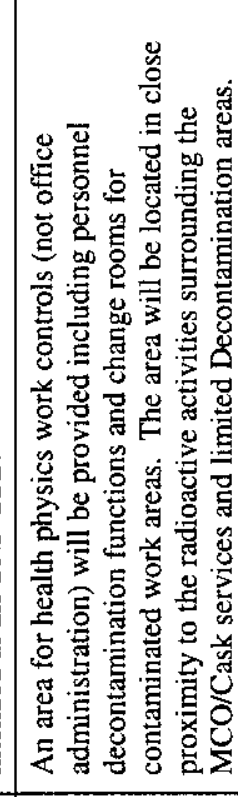 & 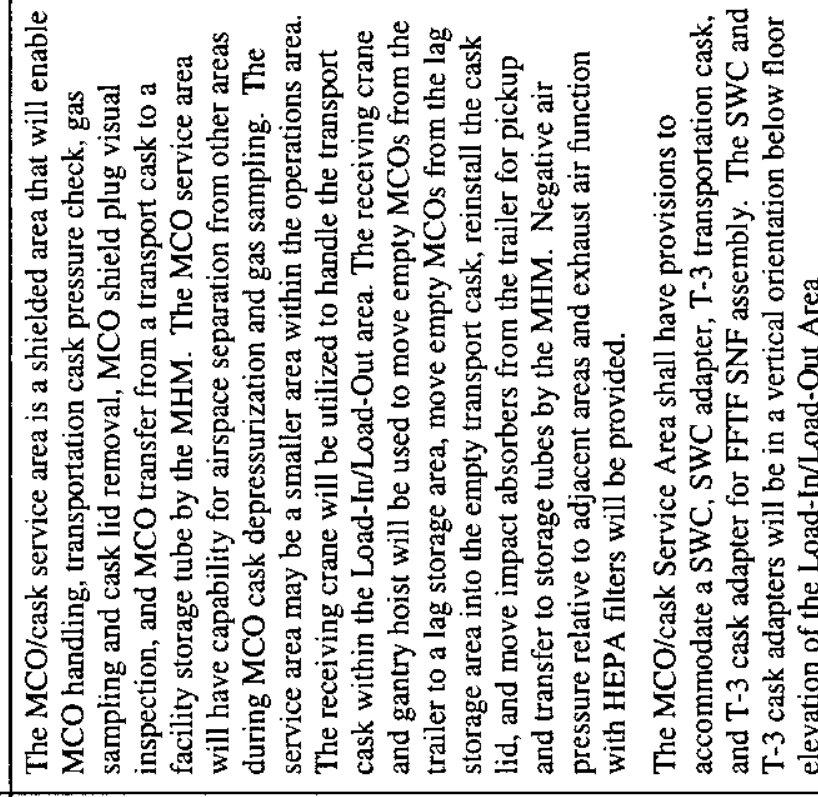 \\
\hline & 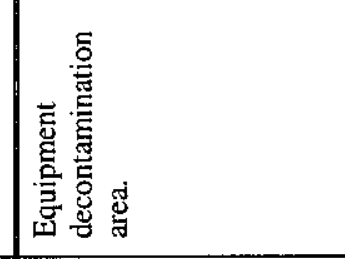 & 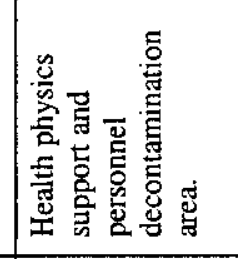 & 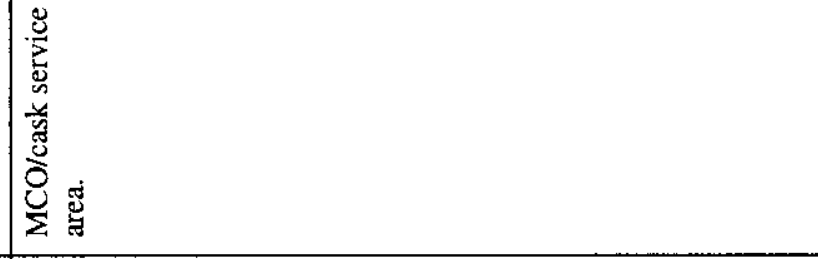 \\
\hline 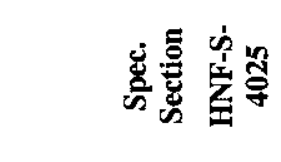 & 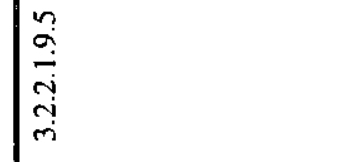 & 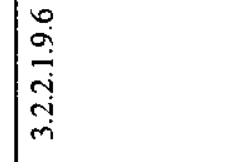 & 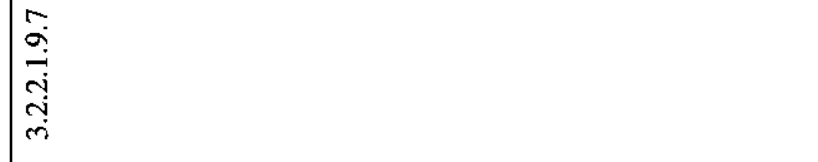 \\
\hline 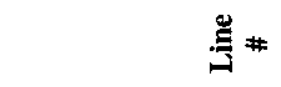 & $\infty$ & q & in \\
\hline
\end{tabular}




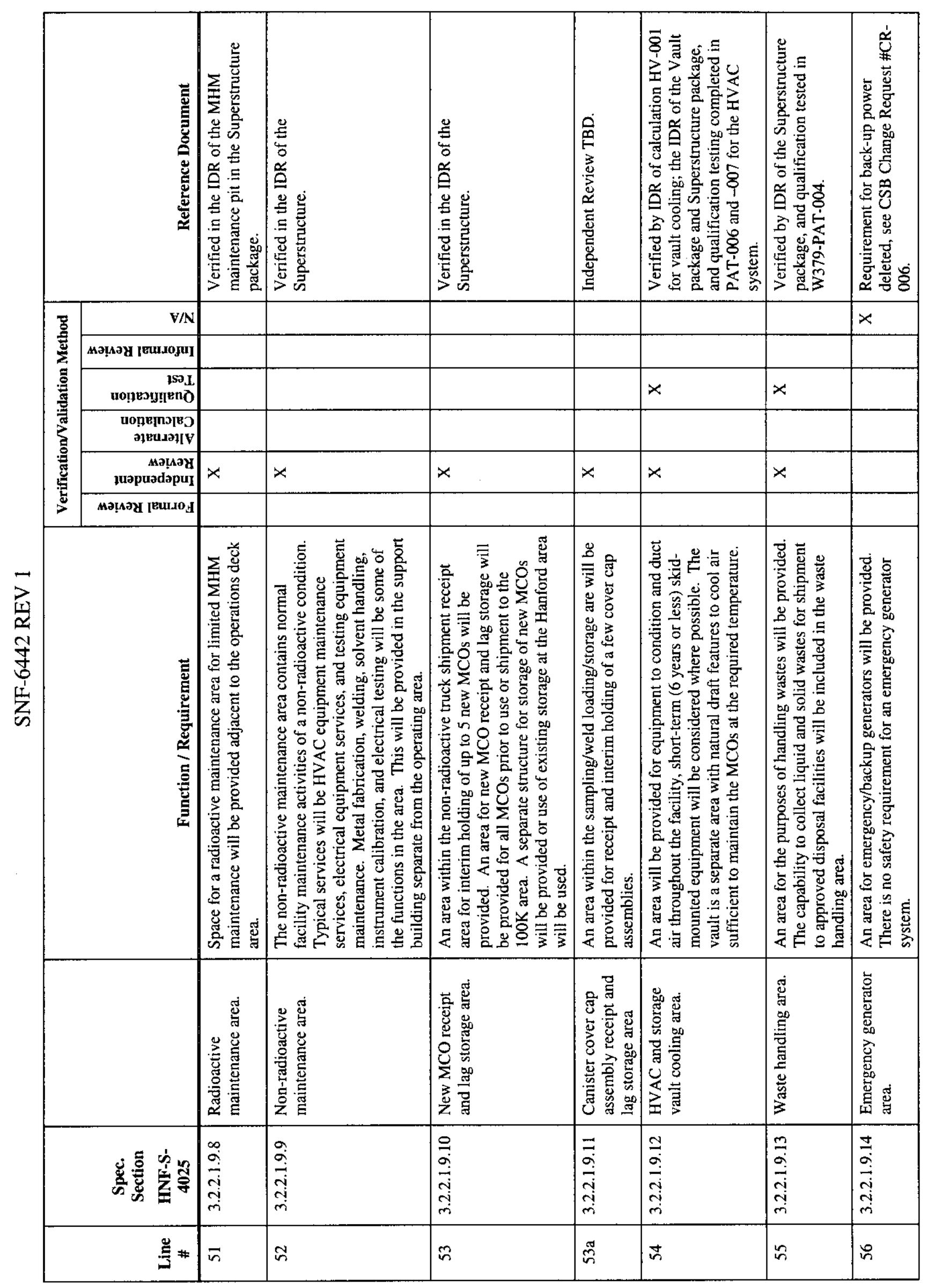




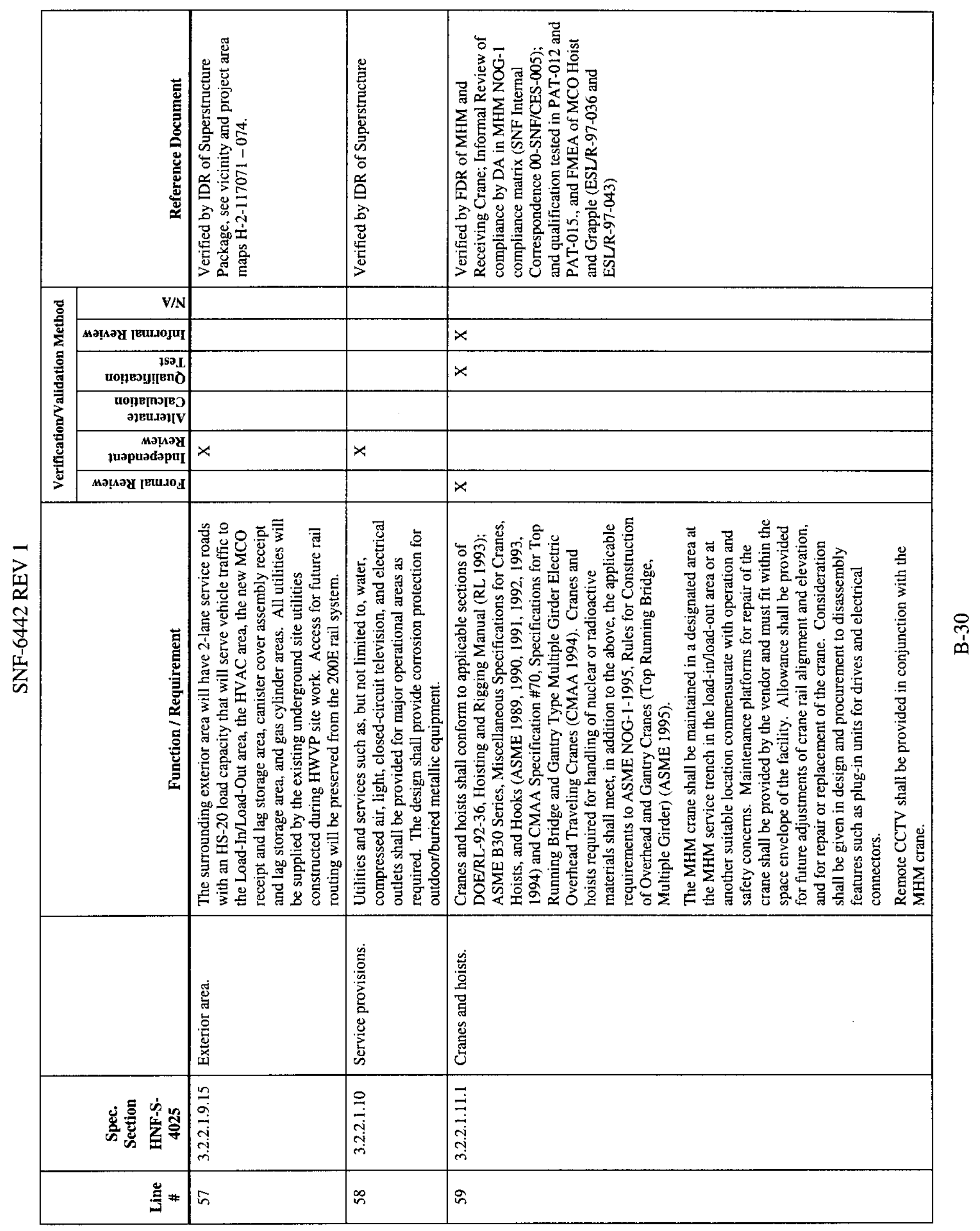




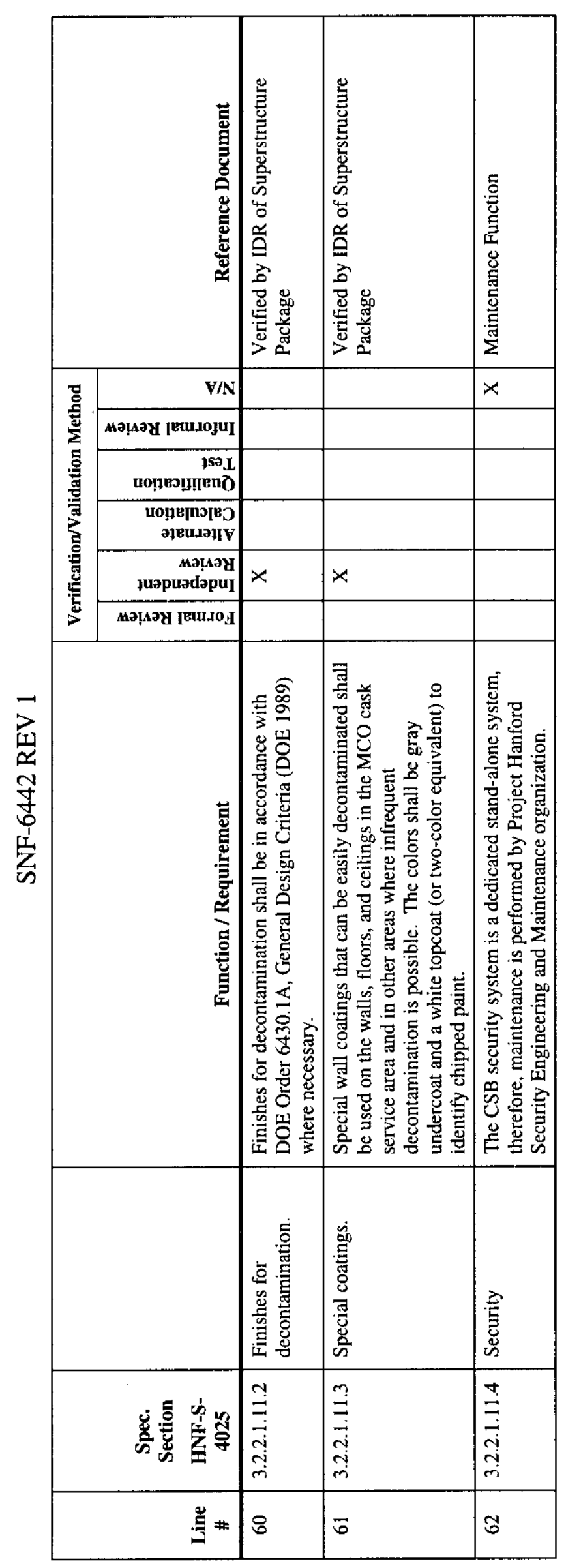

$m$ 


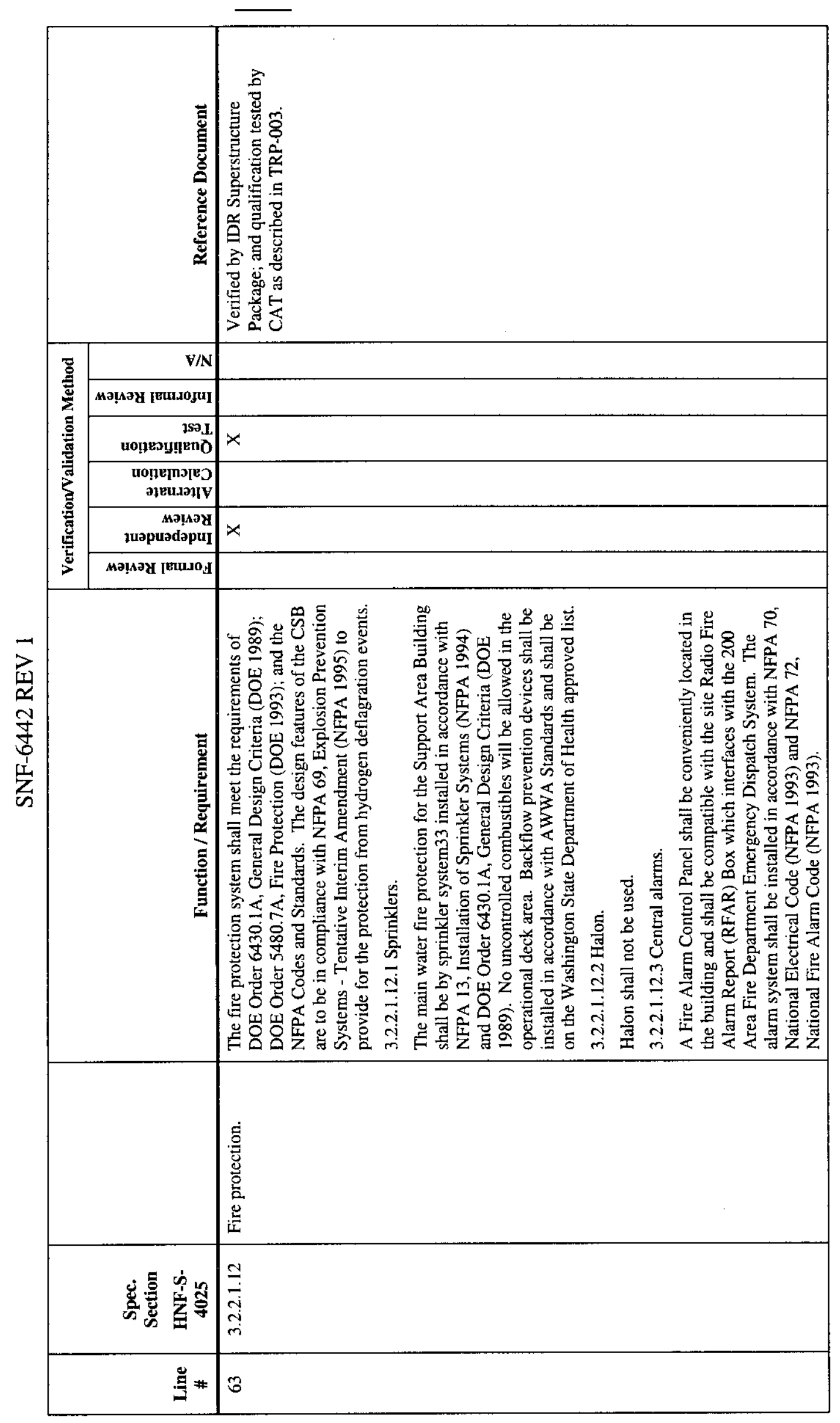

ติ 


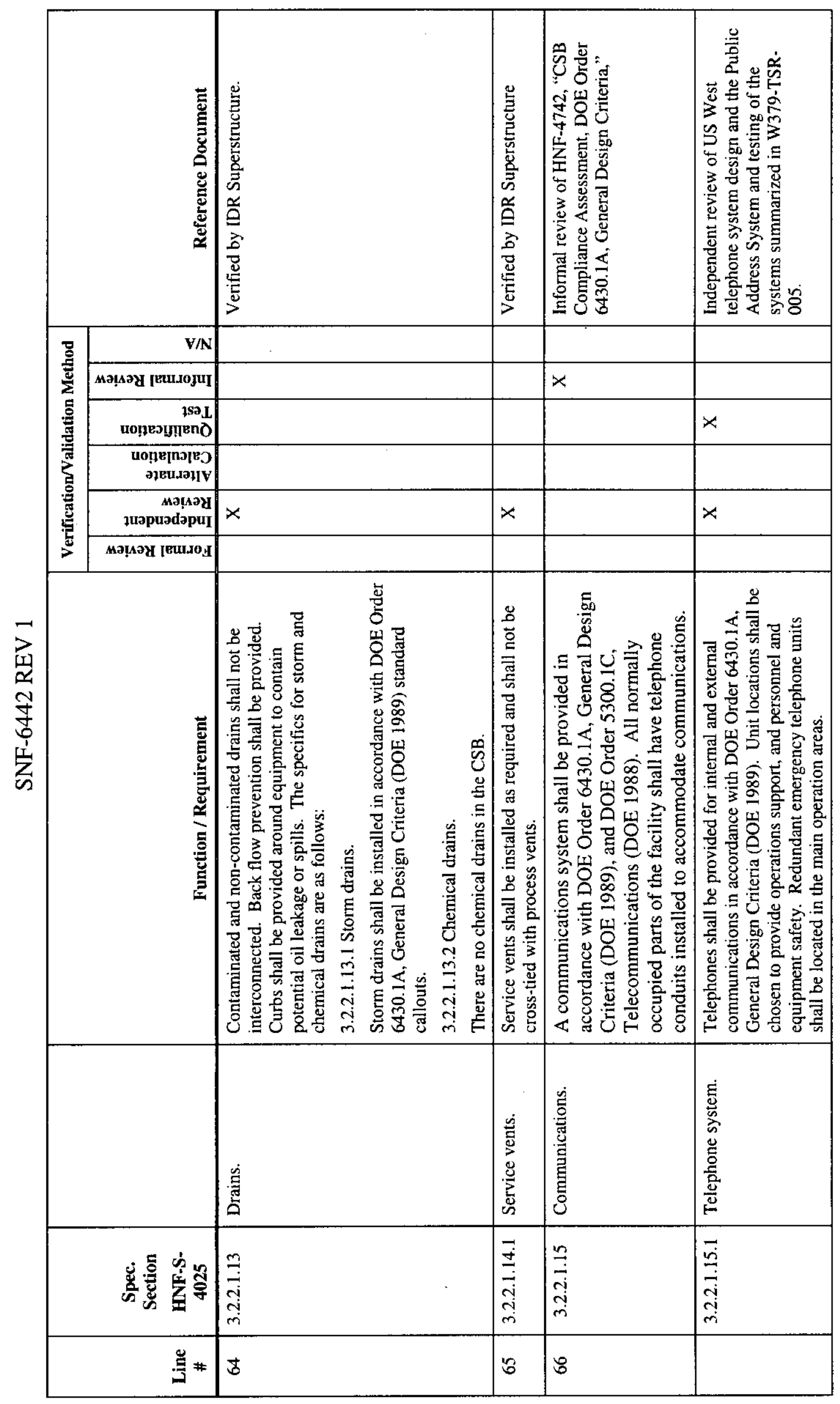




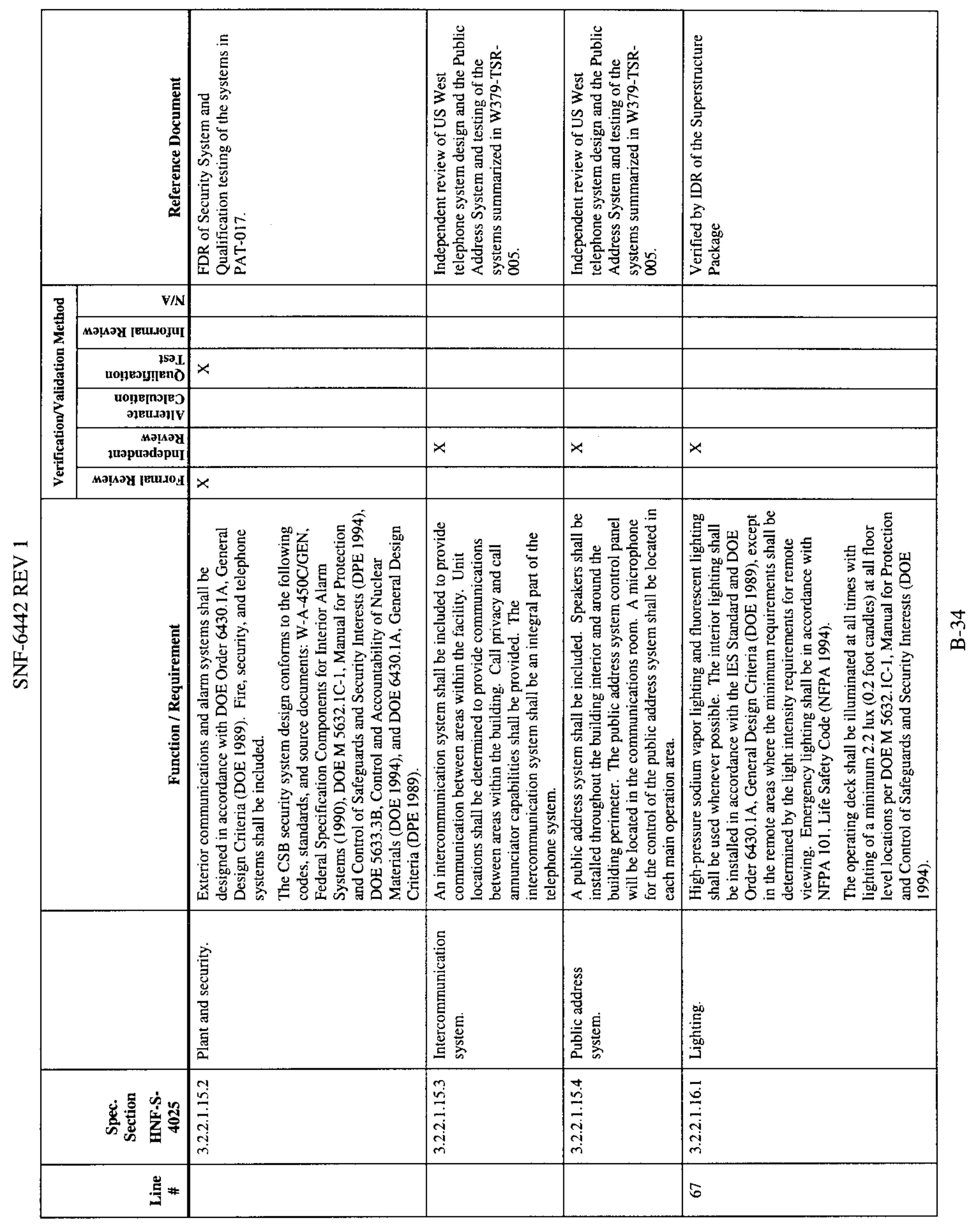




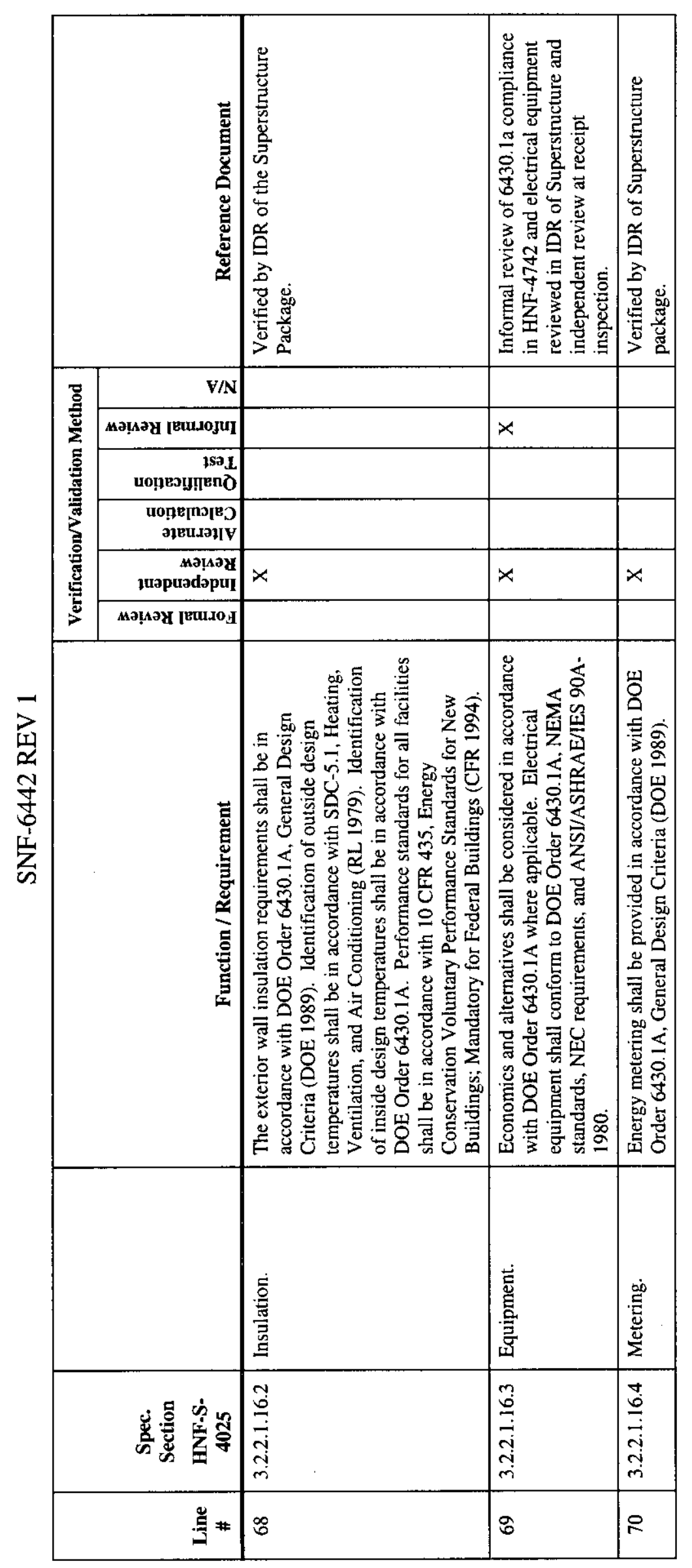




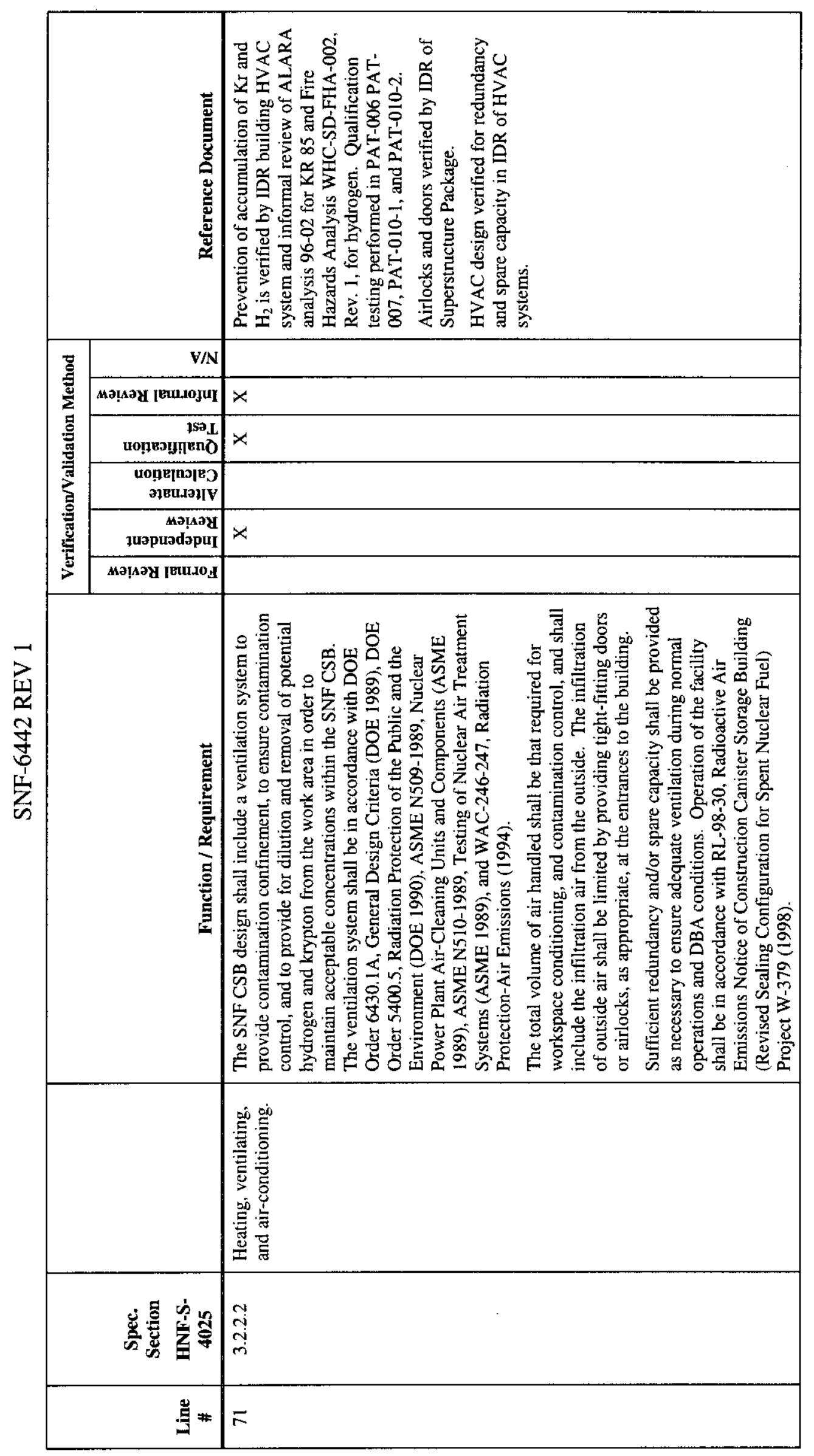

m 


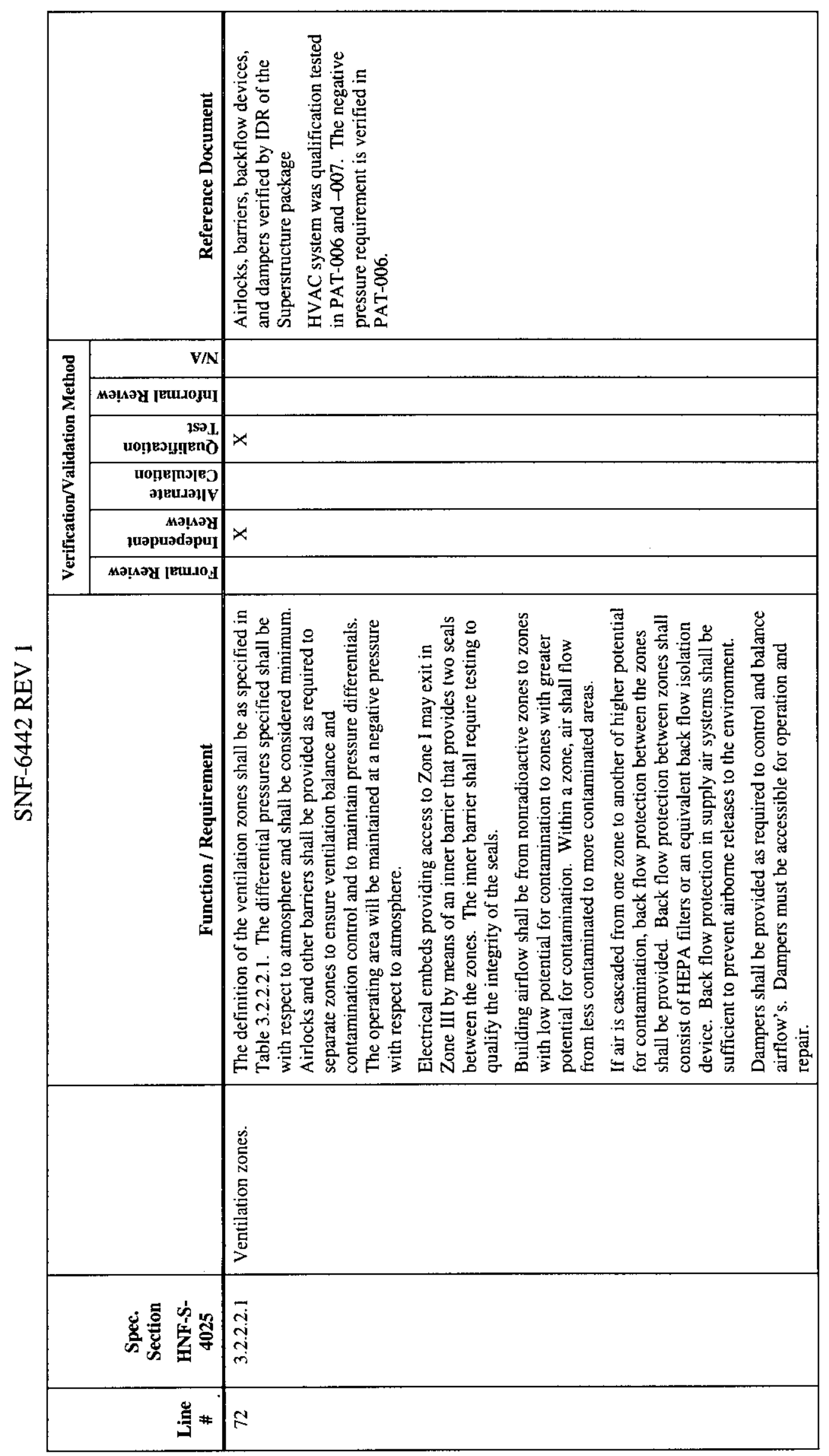

n 


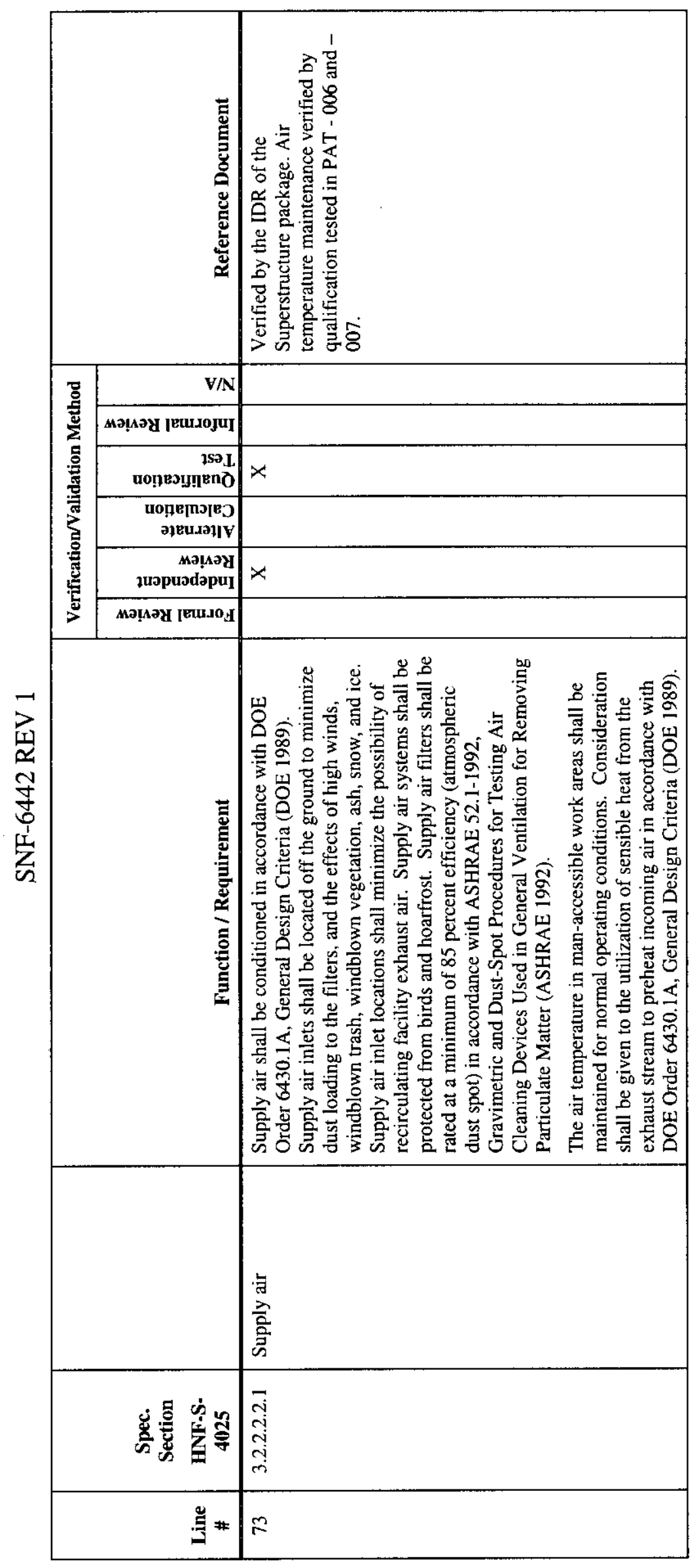

$\stackrel{\infty}{m}$ 


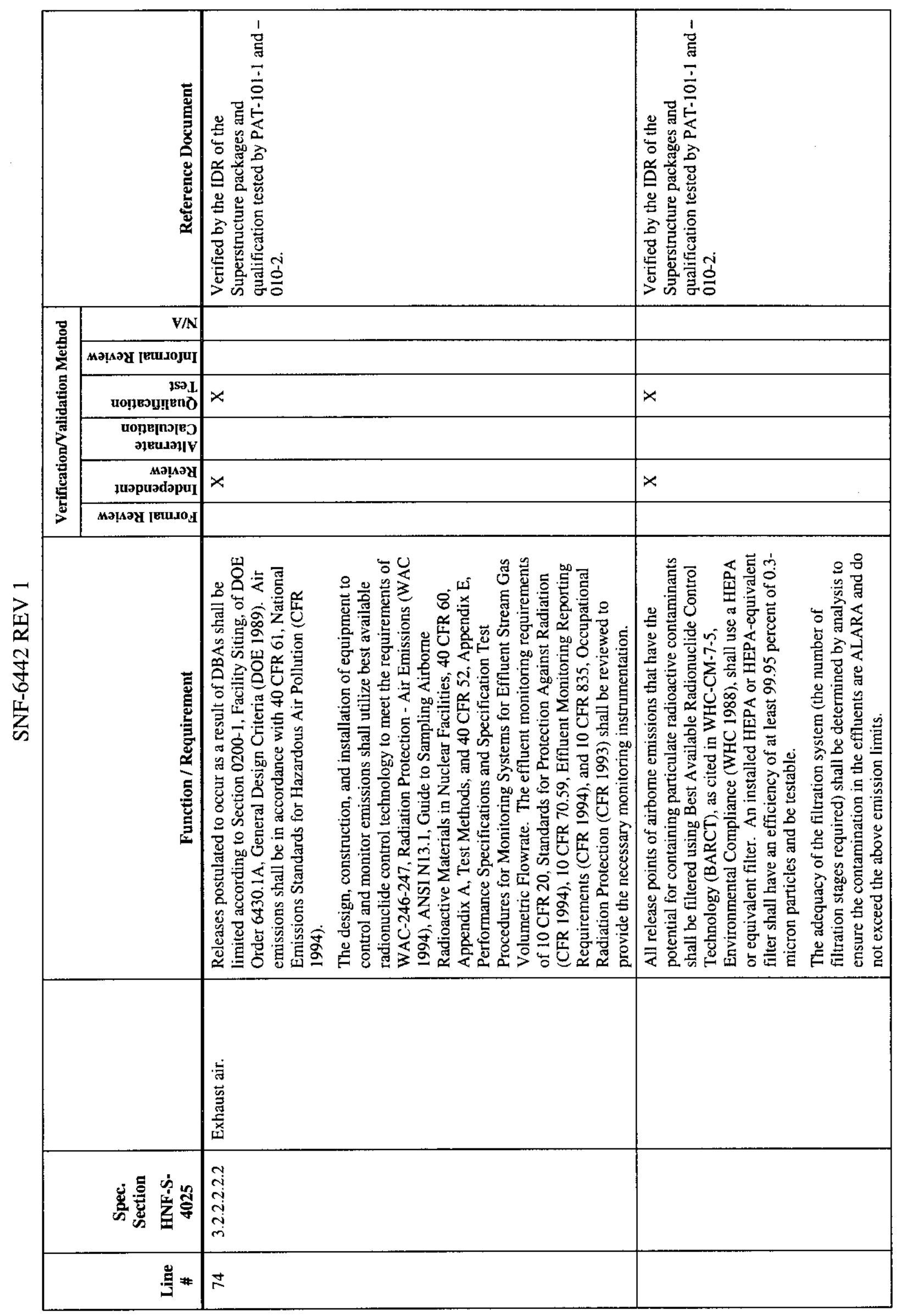




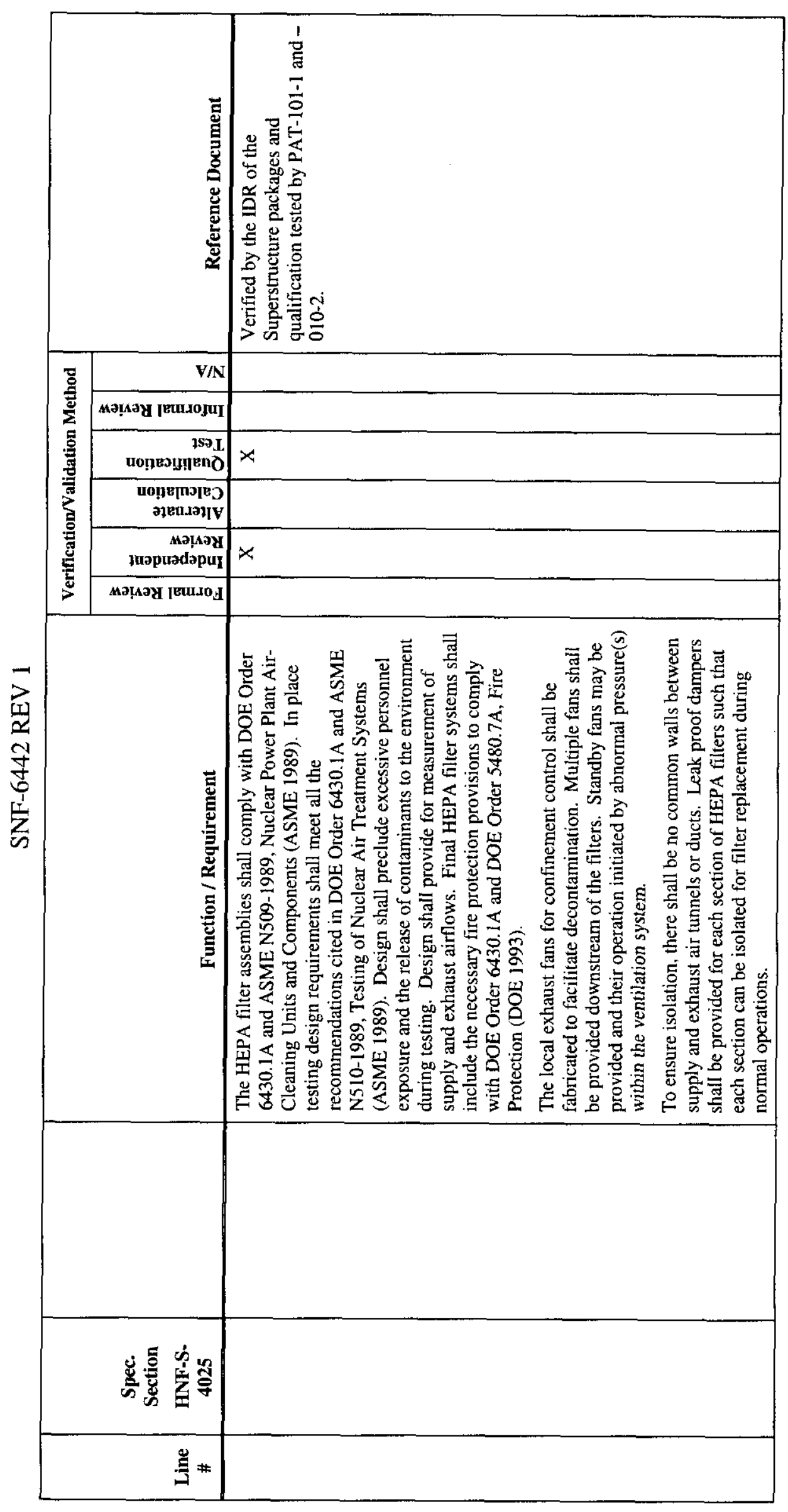

$\underset{\substack{0 \\ \text { m }}}{0}$ 


\begin{tabular}{|c|c|c|c|c|}
\hline & 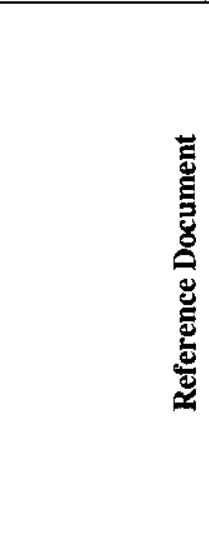 & 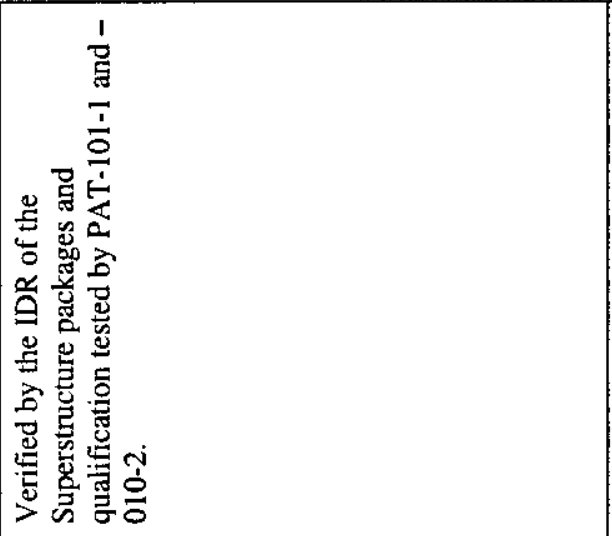 & 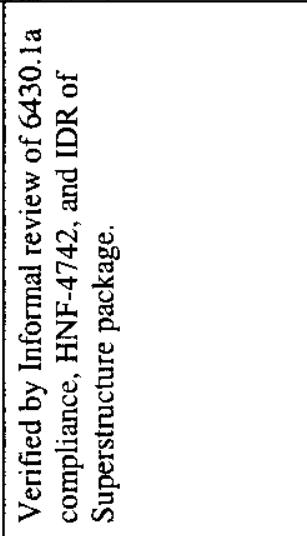 & 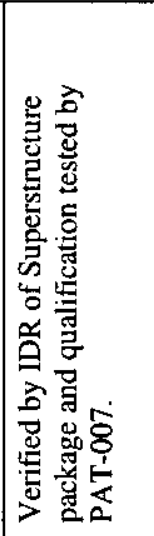 \\
\hline \multirow{6}{*}{ 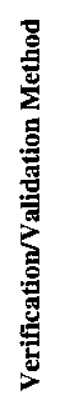 } & $\mathbf{V} / \mathbf{N}$ & & & \\
\hline & 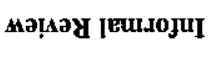 & & $x$ & \\
\hline & 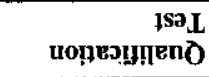 & $x$ & & $x$ \\
\hline & 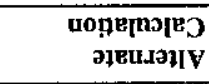 & & & \\
\hline & $\begin{array}{r}\text { мәцаәу } \\
\text { fuәрuаdəрuI }\end{array}$ & $x$ & $x$ & $x$ \\
\hline & 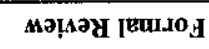 & & & \\
\hline \multirow{2}{*}{\multicolumn{2}{|c|}{ 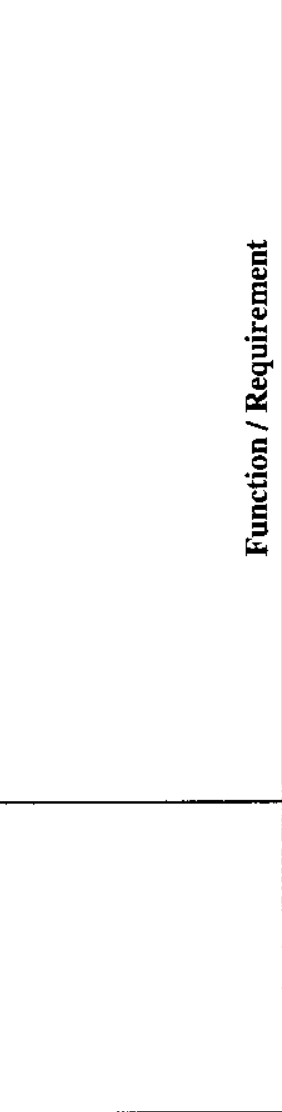 }} & 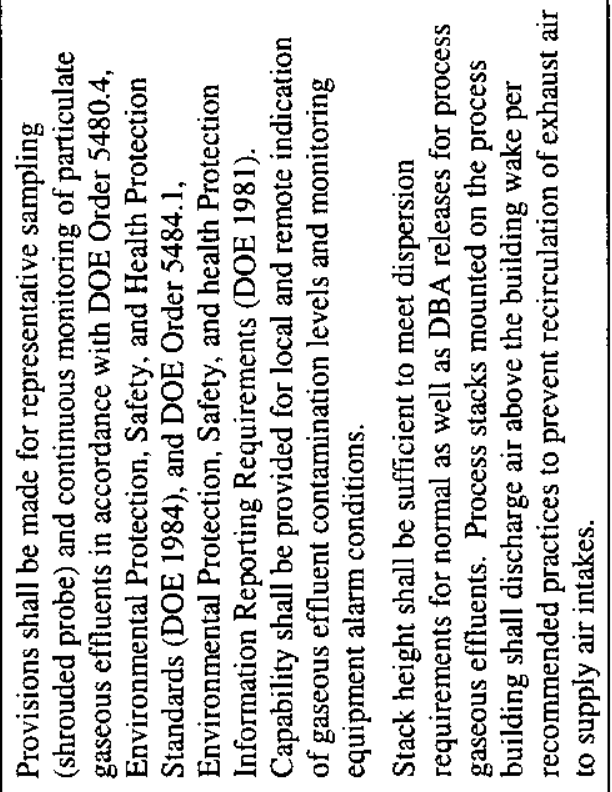 & 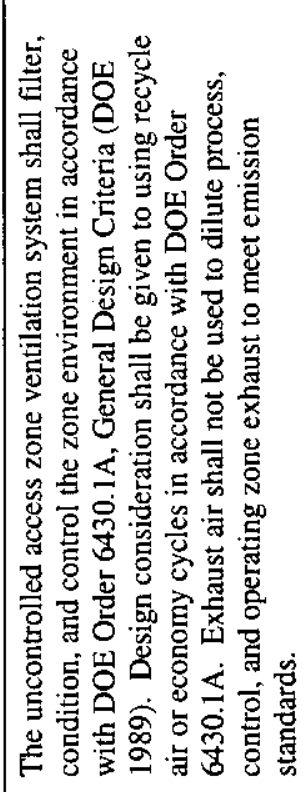 & 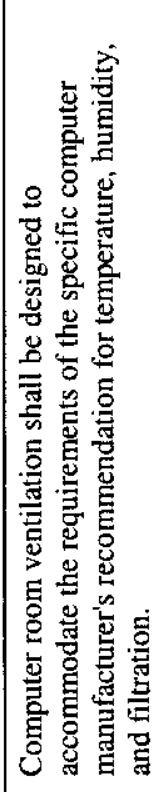 \\
\hline & & & 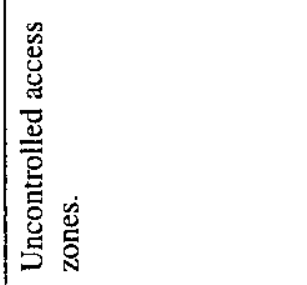 & 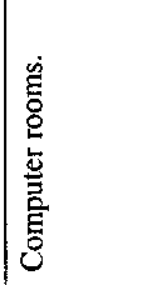 \\
\hline & 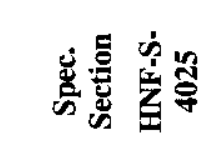 & & $\begin{array}{l}\underset{n}{\tilde{j}} \\
\underset{n}{n} \\
\ddot{n}\end{array}$ & $\begin{array}{l}\vec{m} \\
\ddot{n} \\
\ddot{d} \\
\ddot{n} \\
\dot{m}\end{array}$ \\
\hline & 岑 & & 2 & 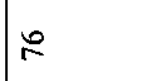 \\
\hline
\end{tabular}




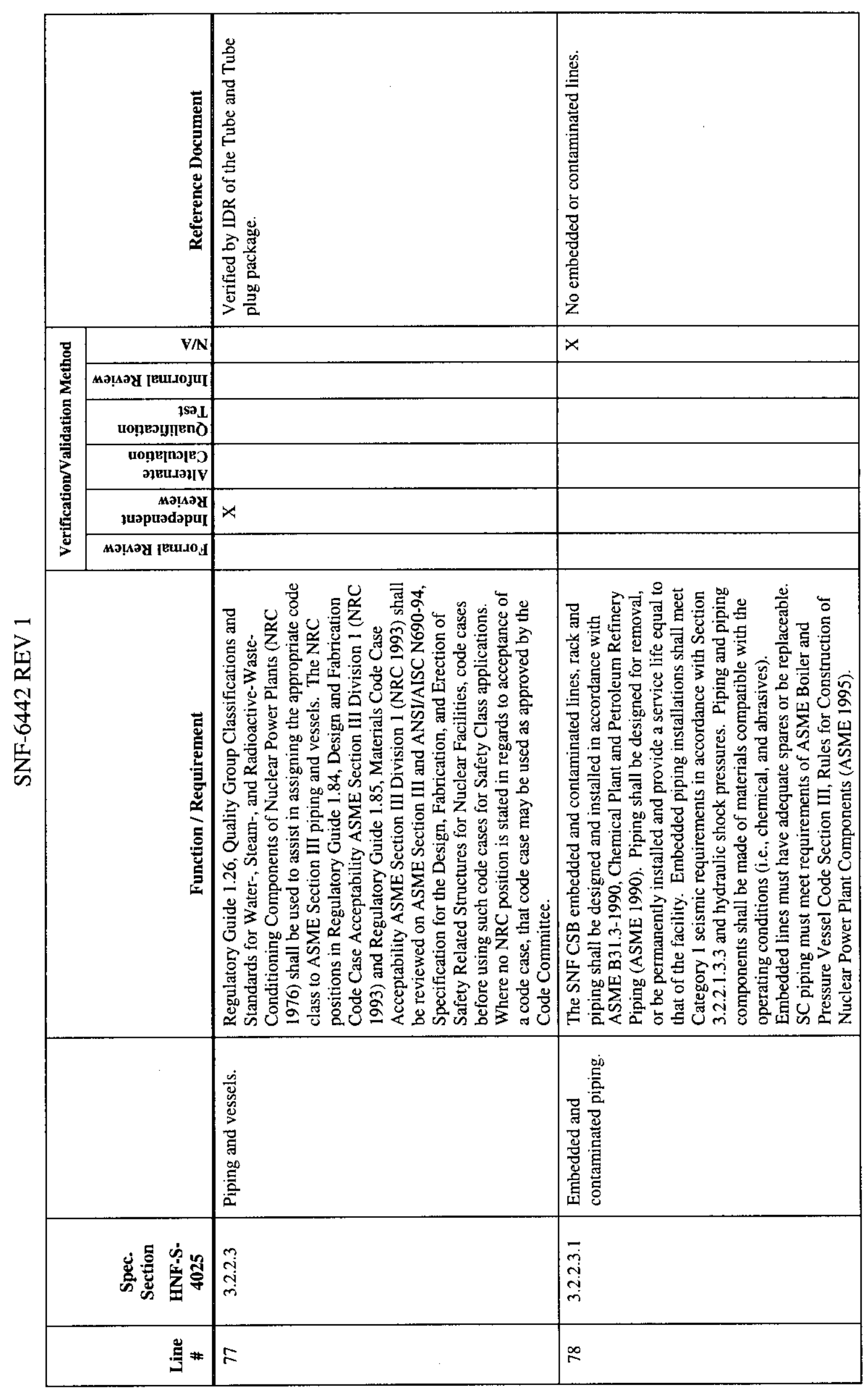




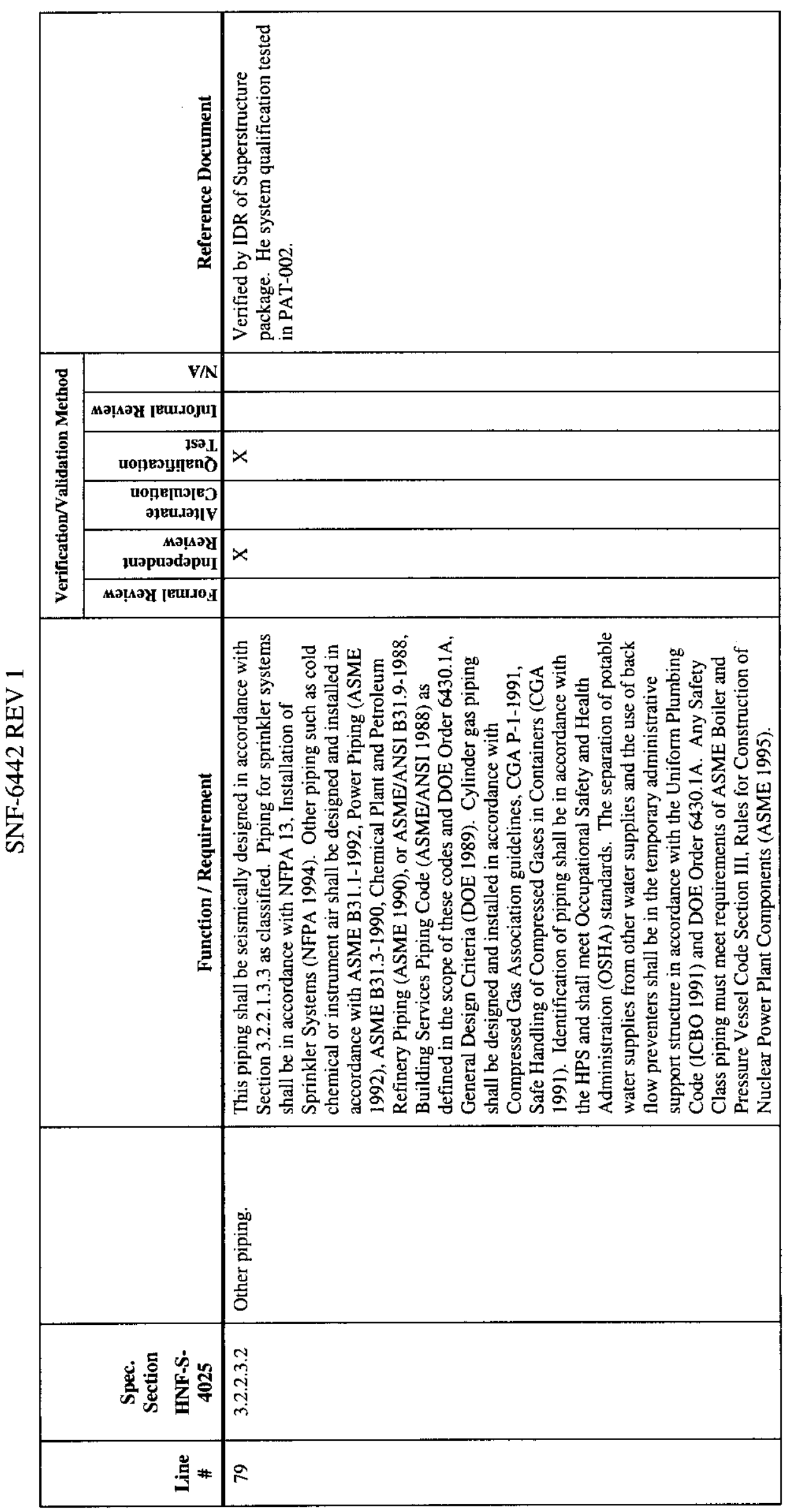

离 


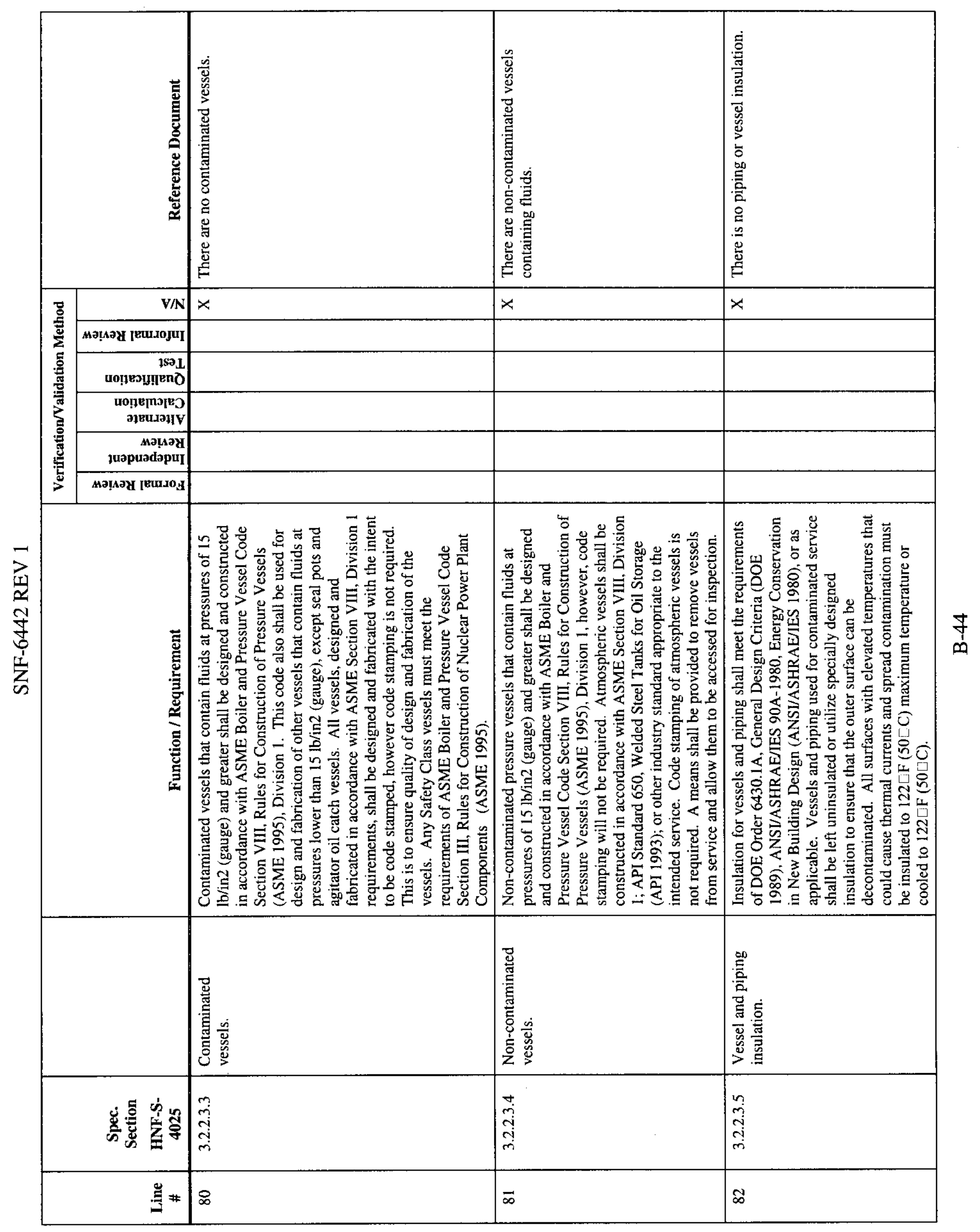




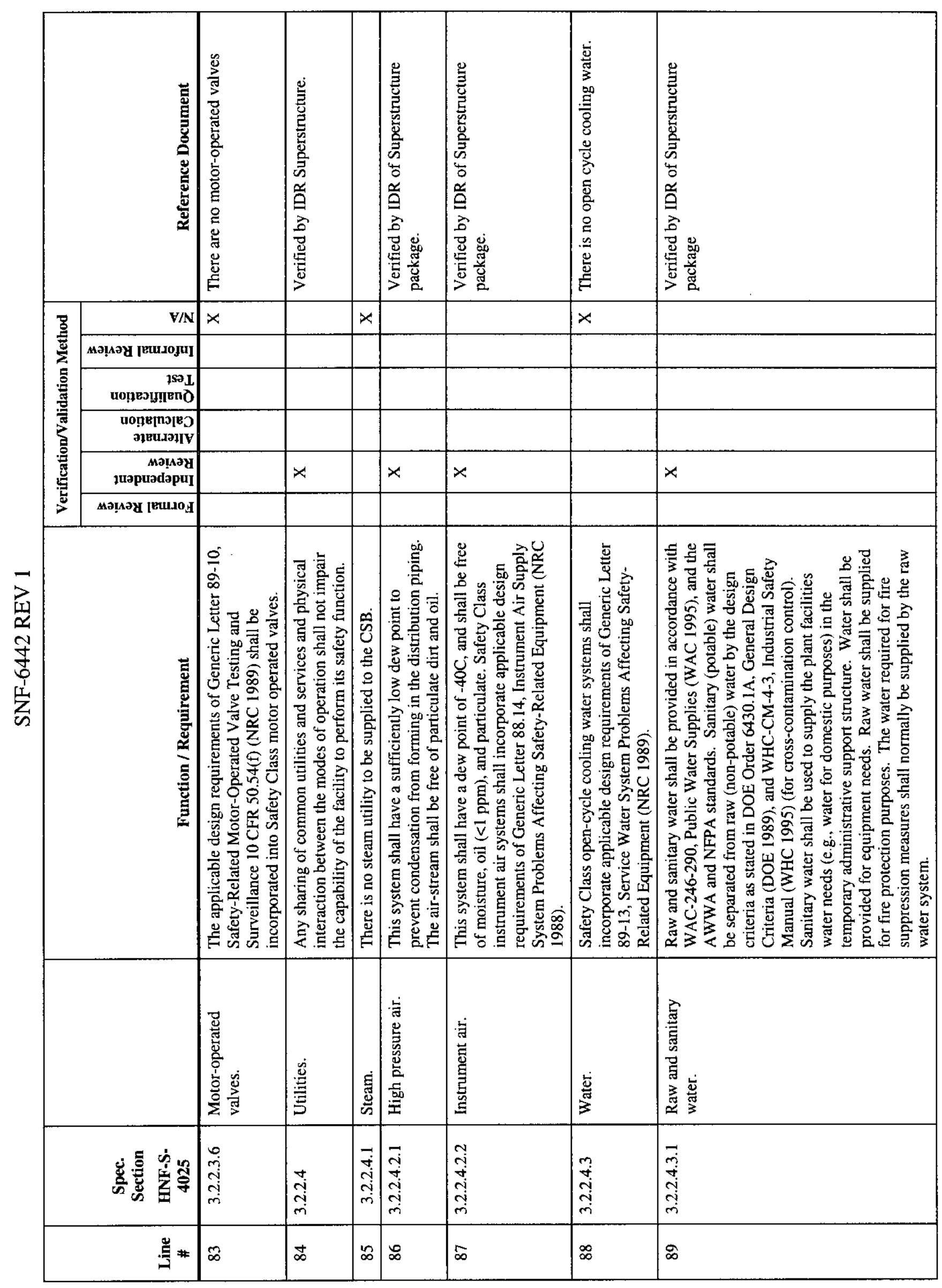

$\stackrel{n}{\stackrel{n}{*}}$ 


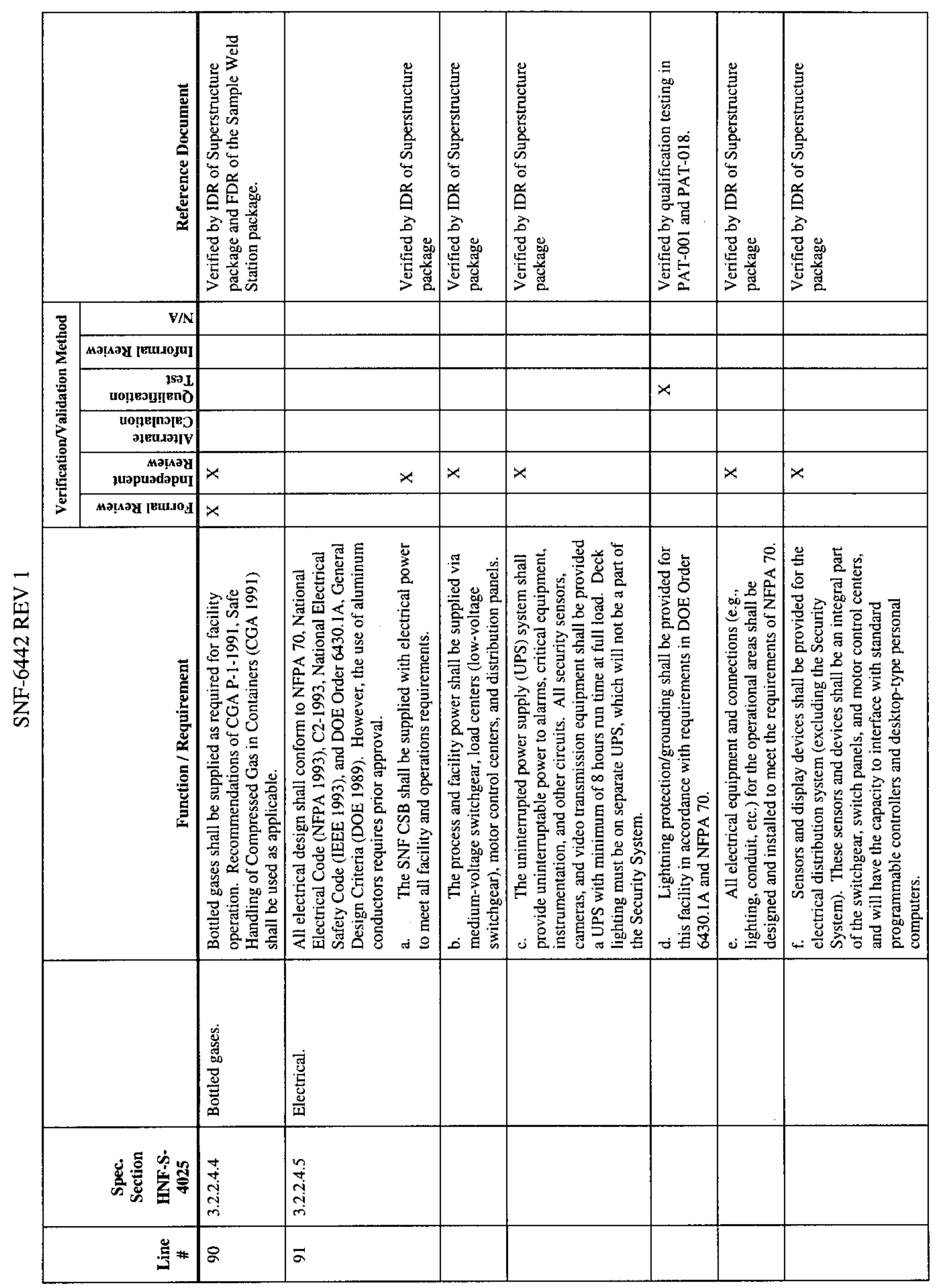

号 


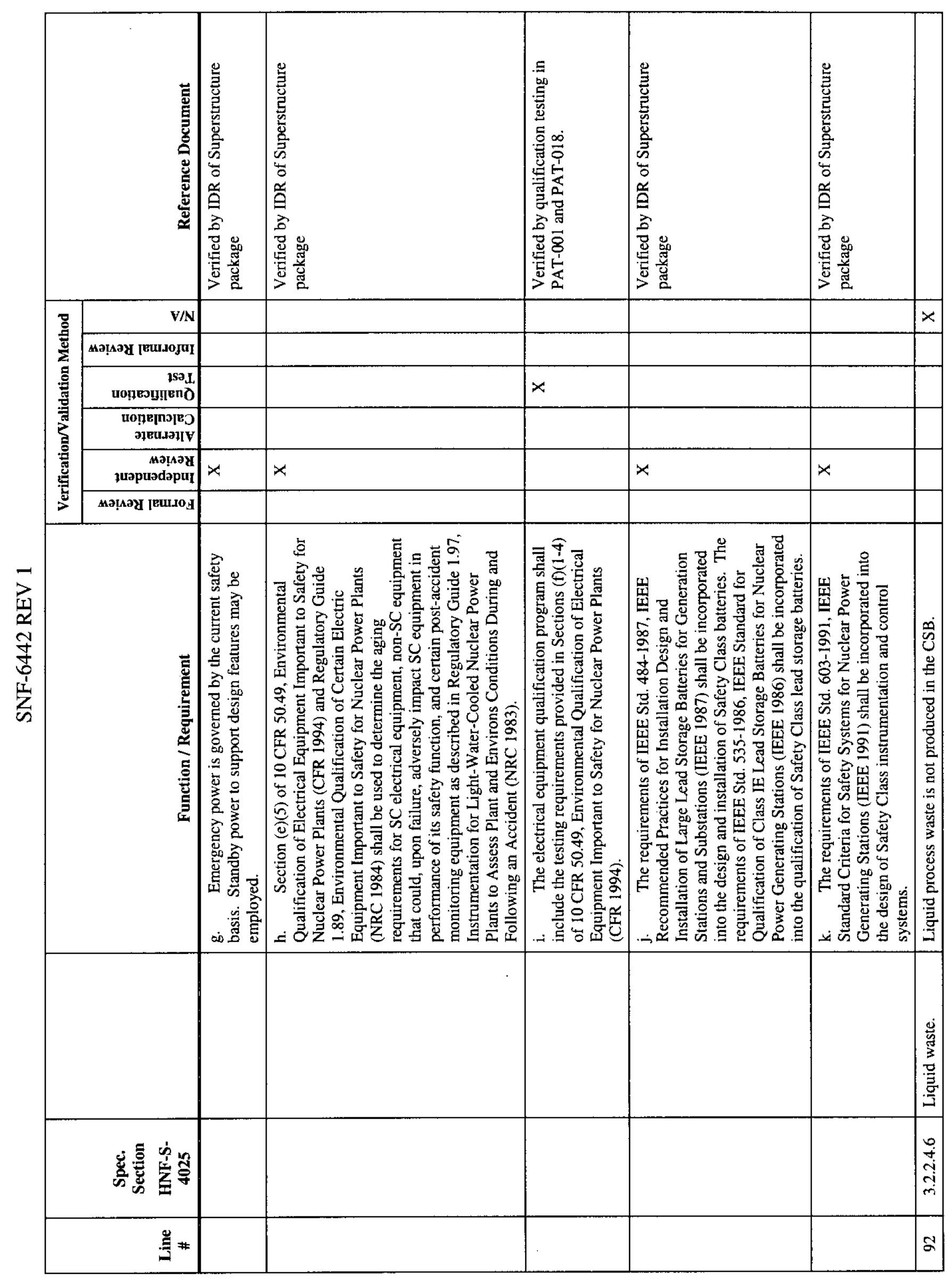




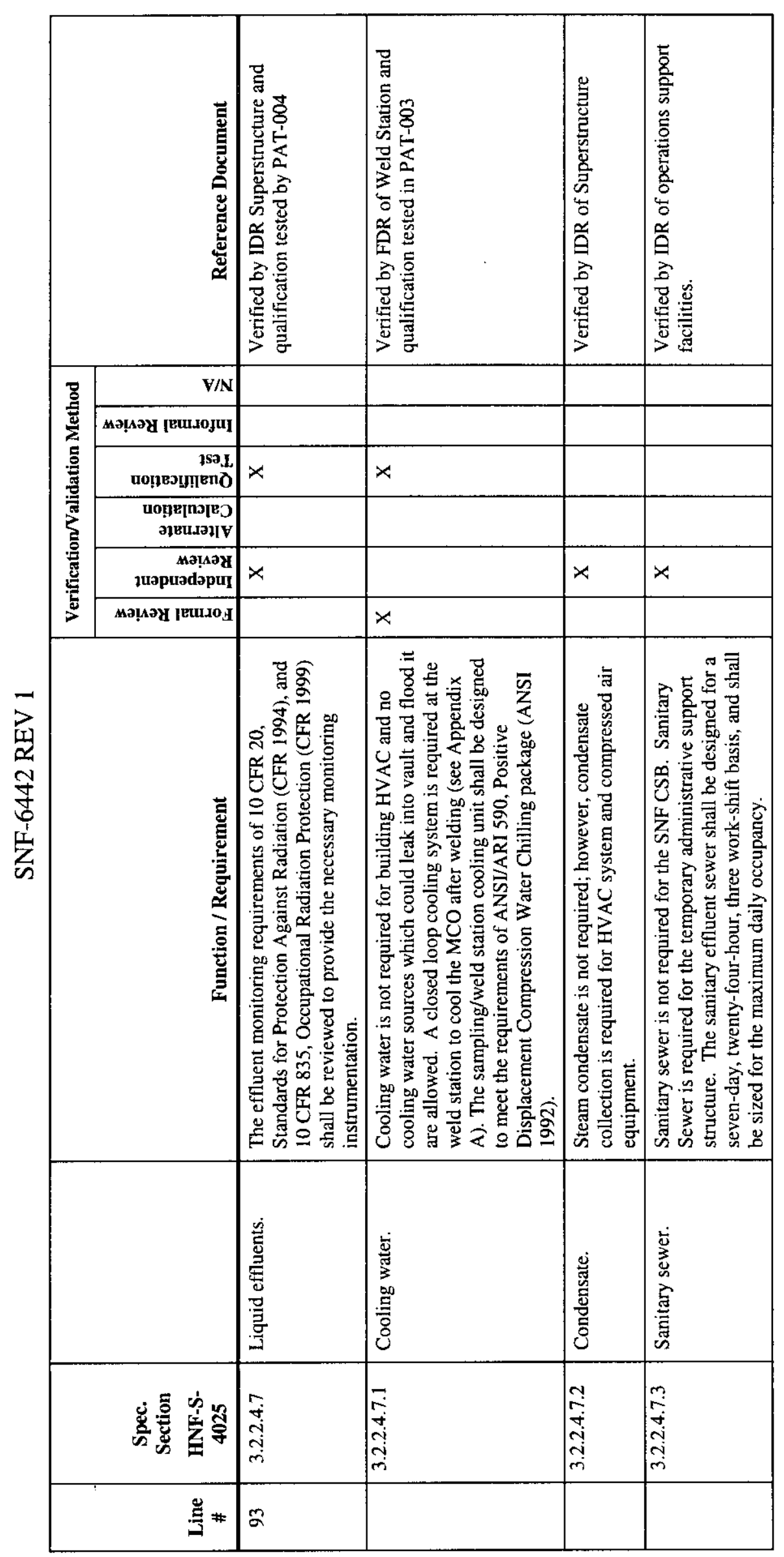

$\underset{1}{\infty}$ 


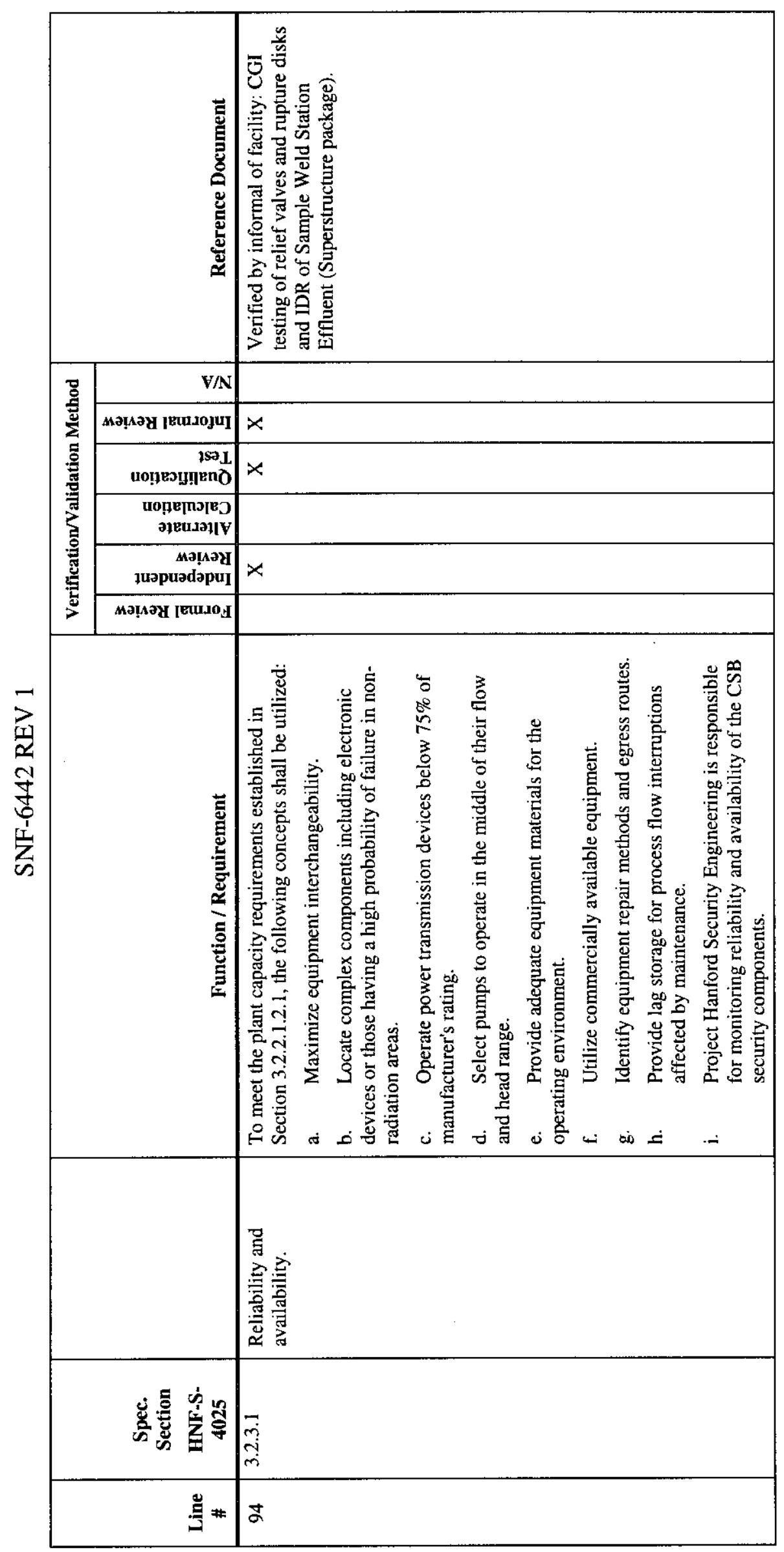

$\stackrel{9}{y}$ 


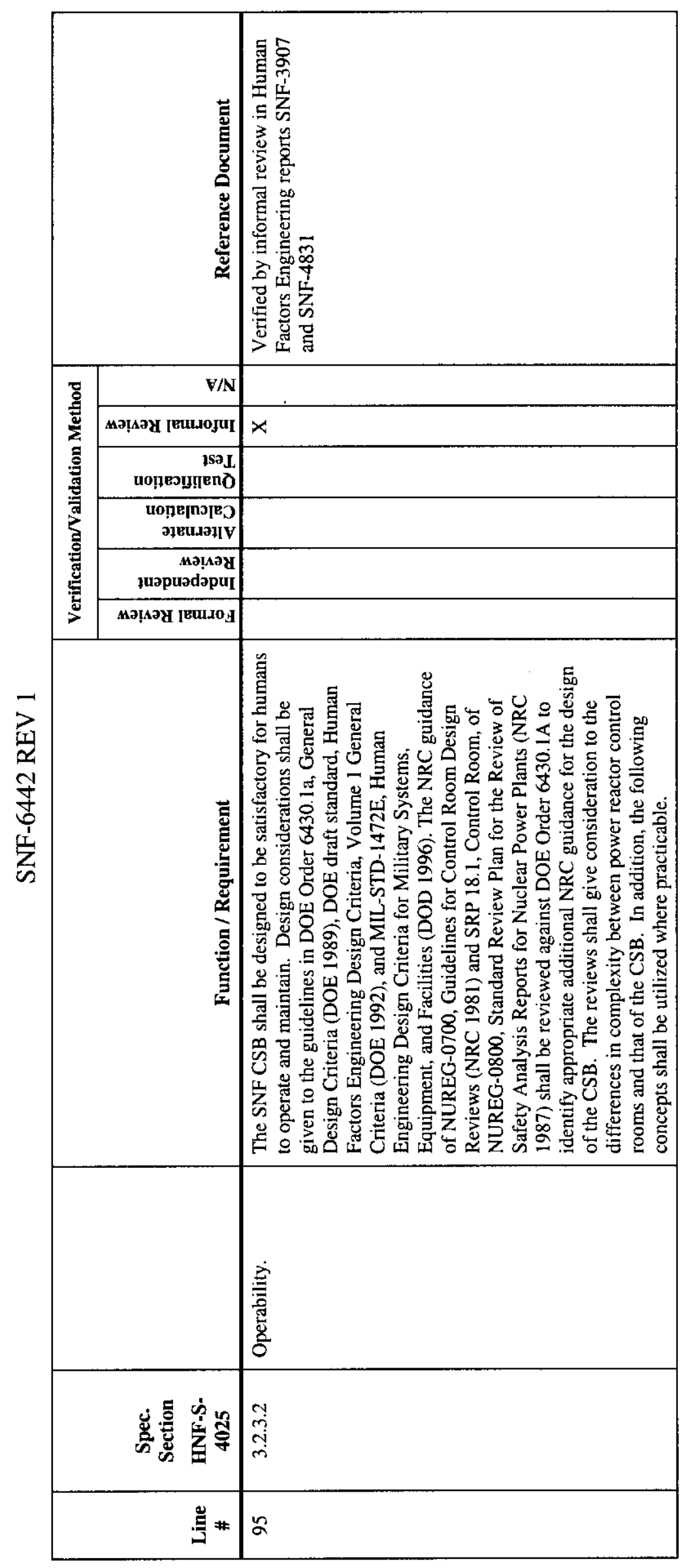




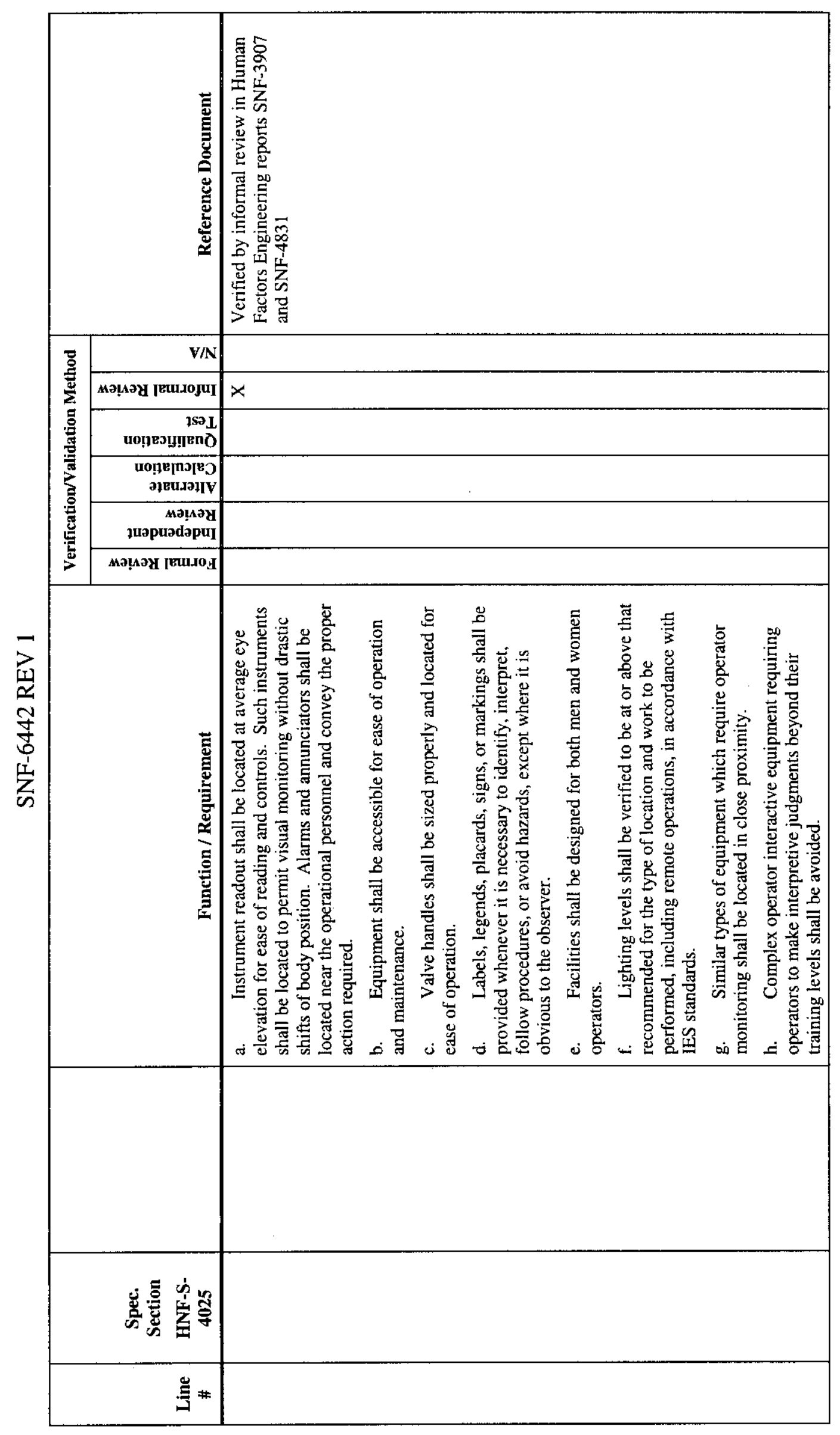




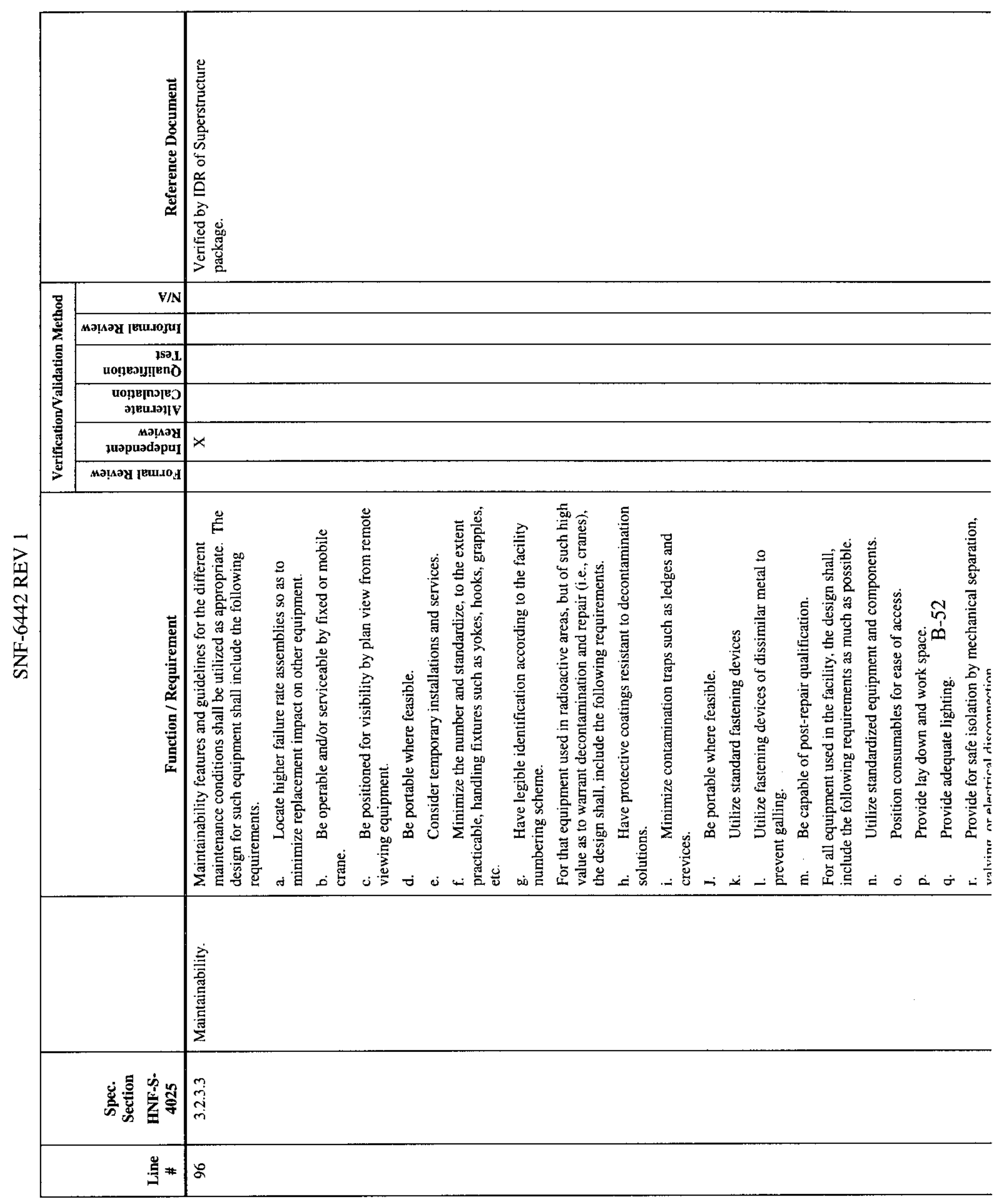




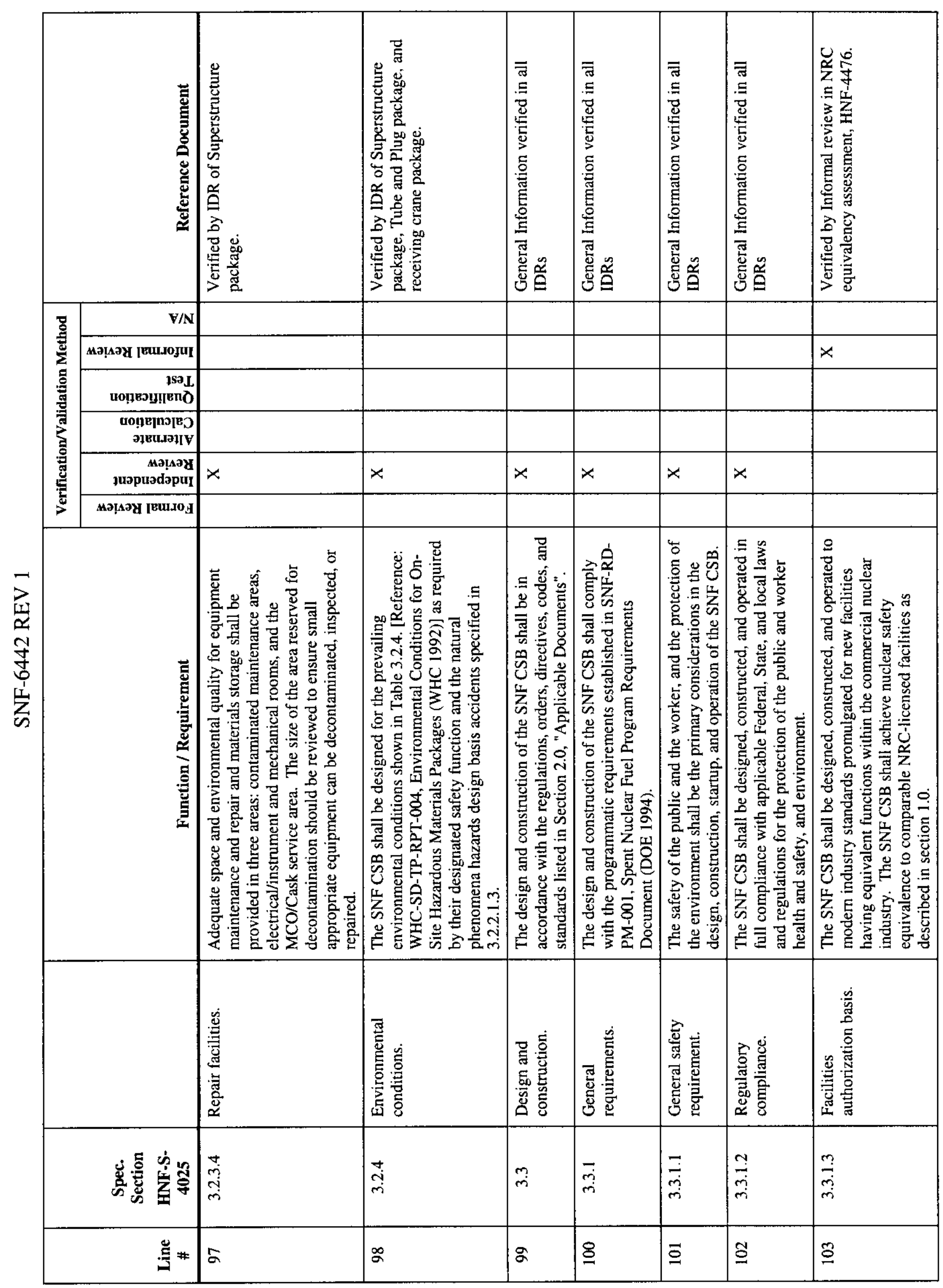

m 


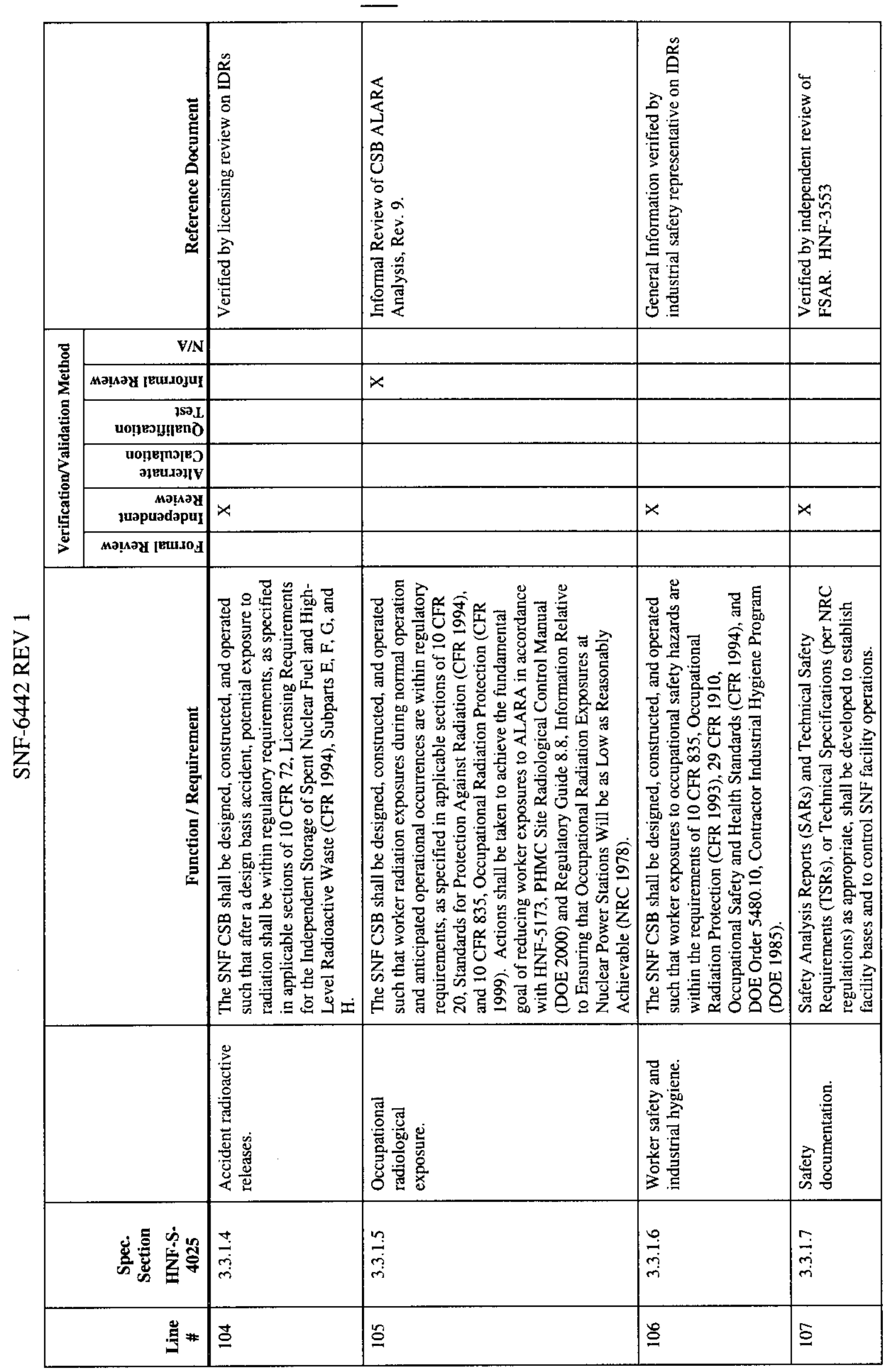




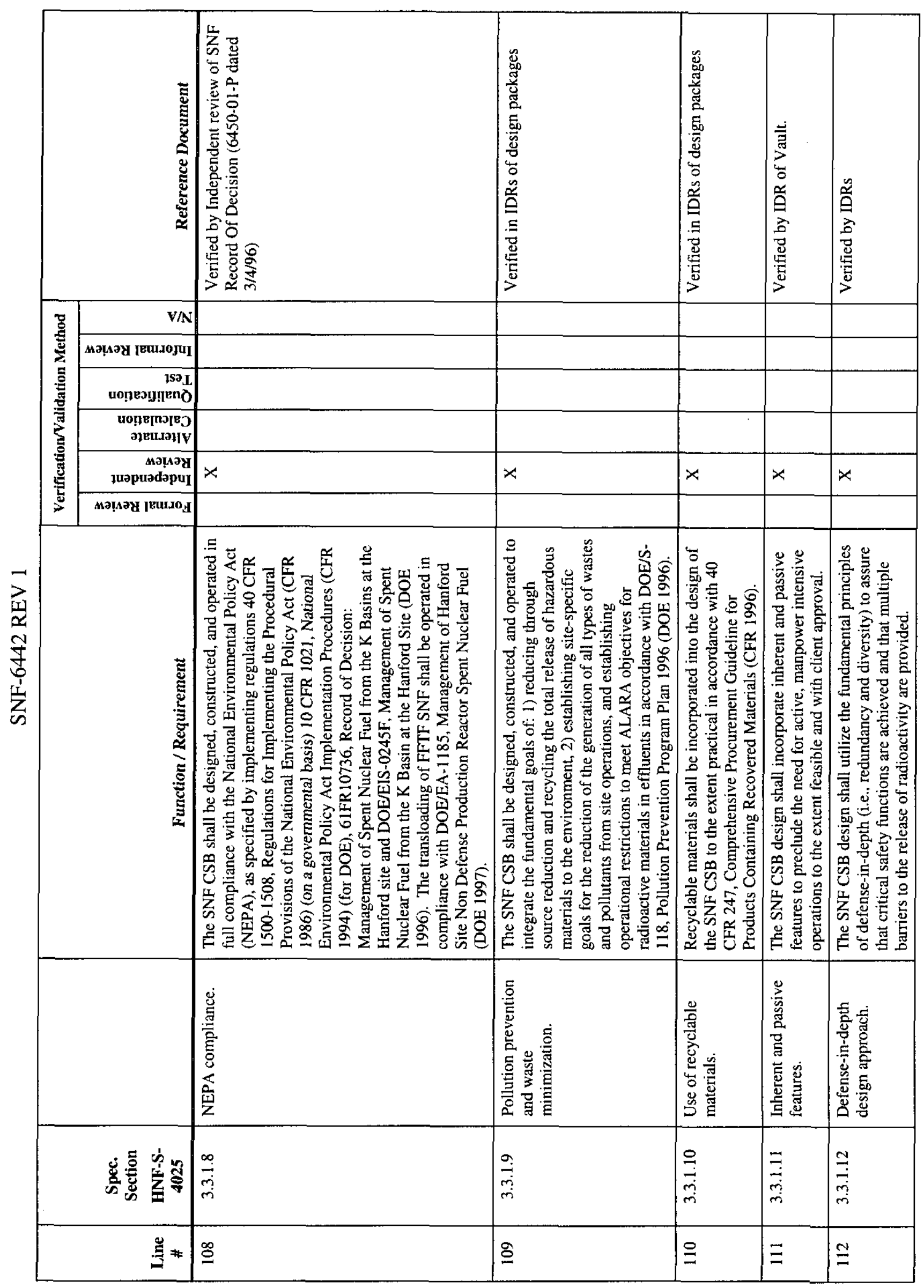

邑 


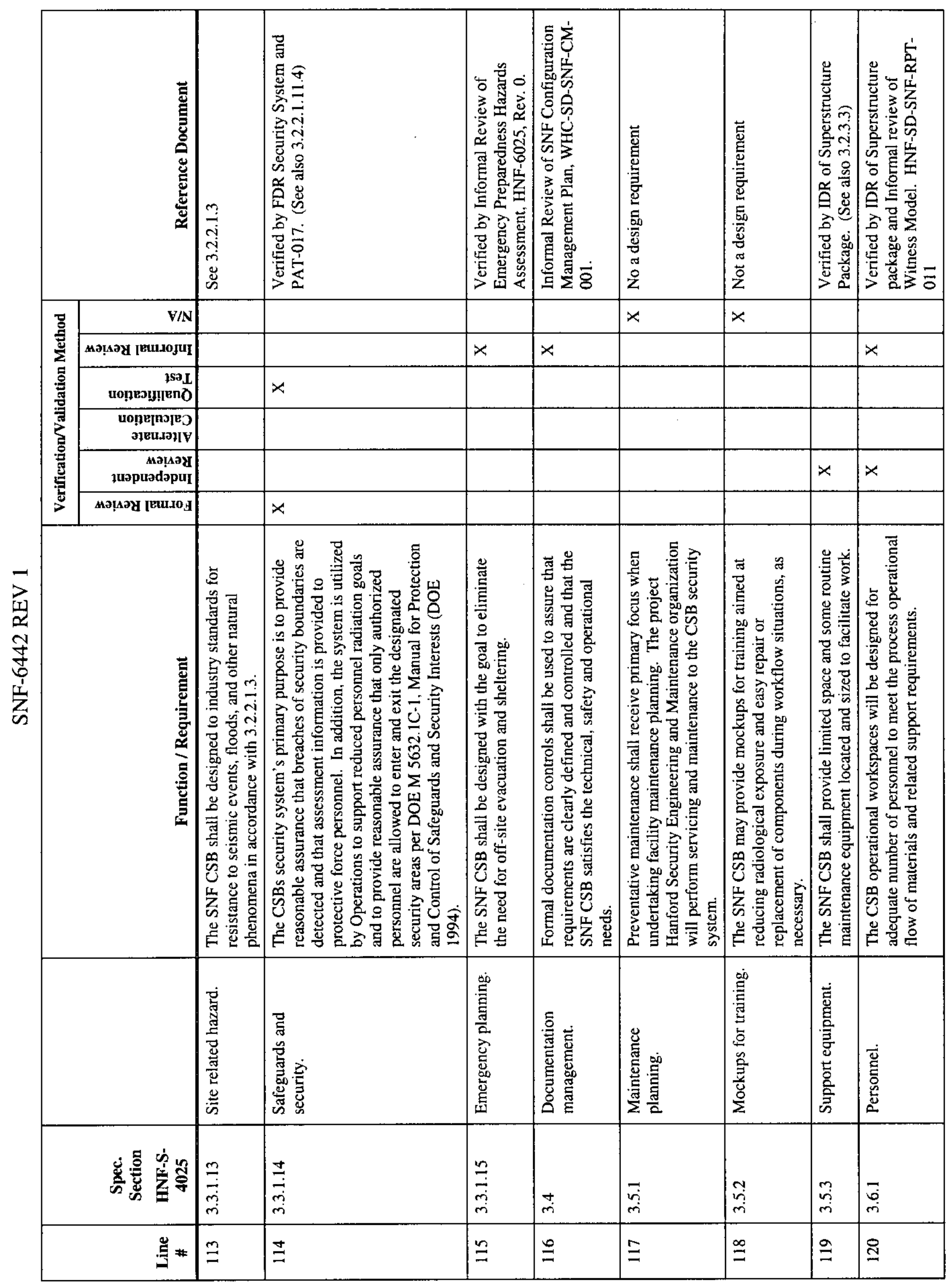




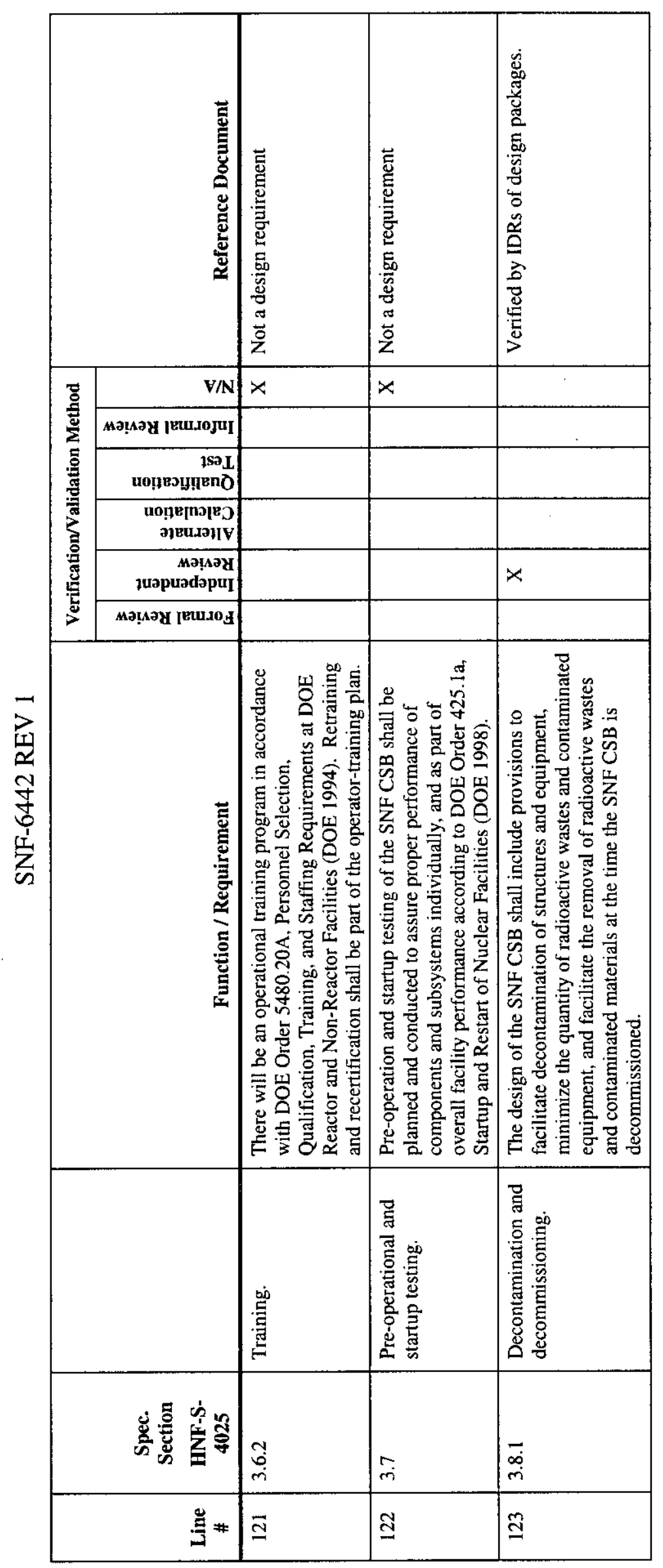

ñ 


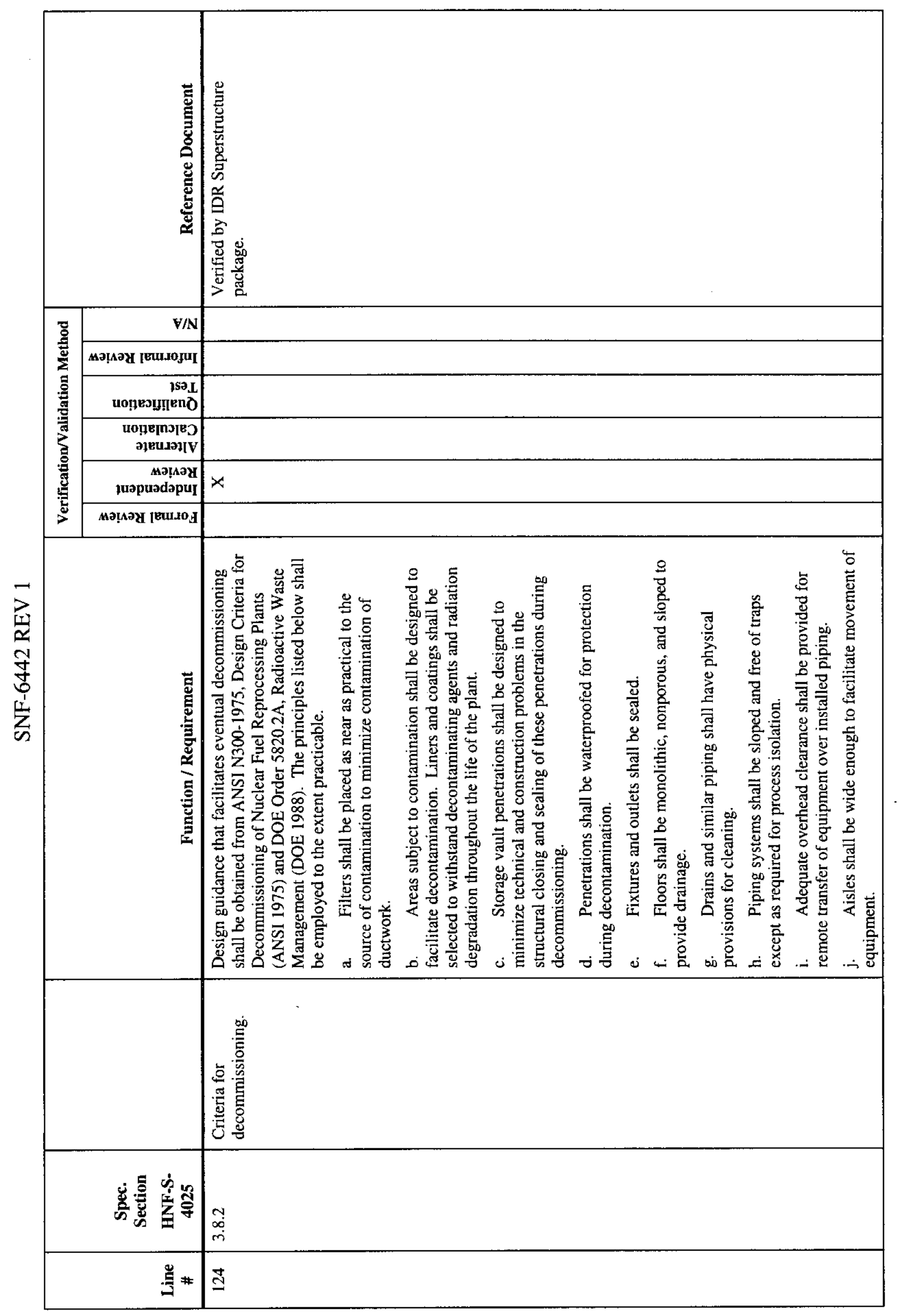




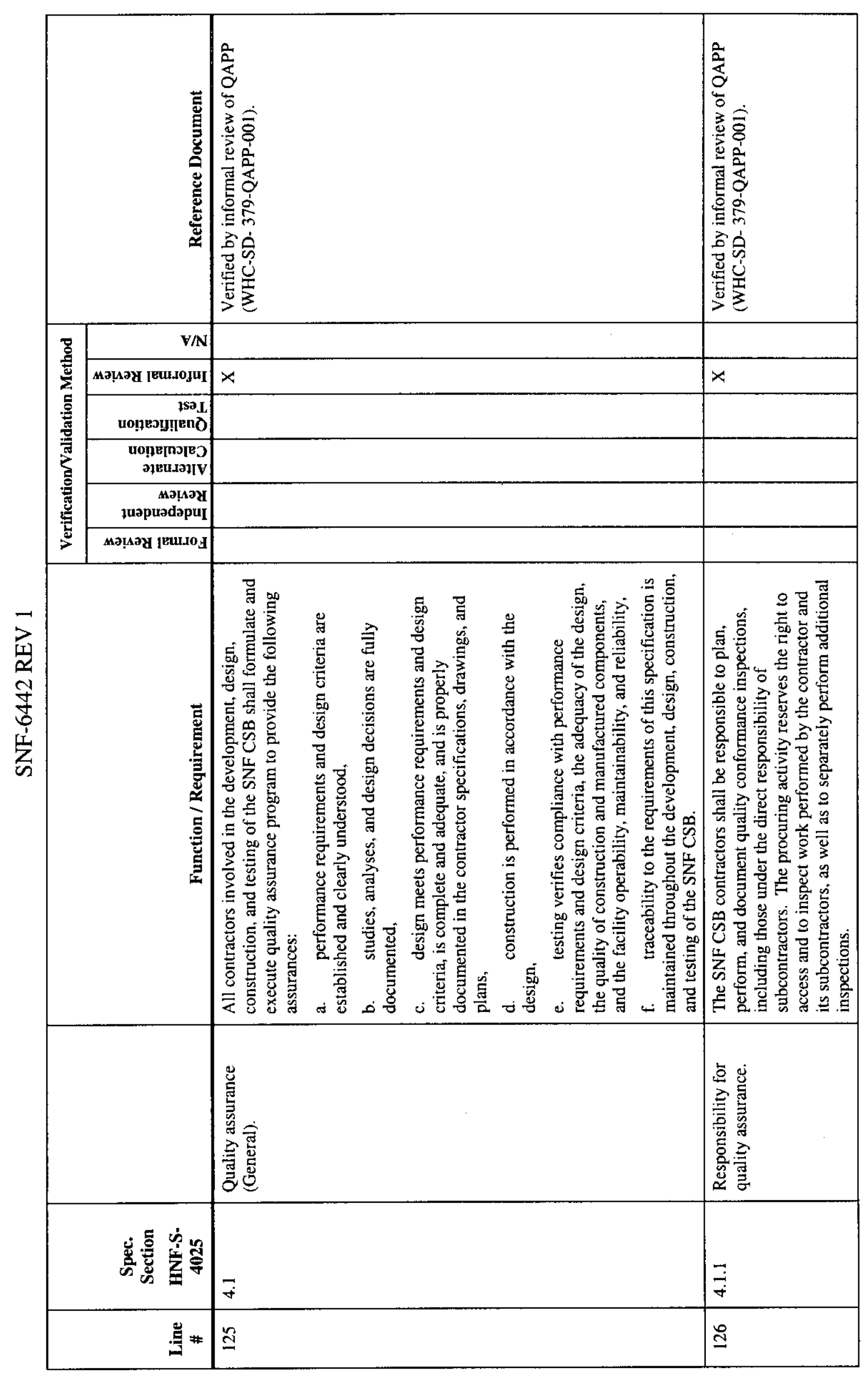




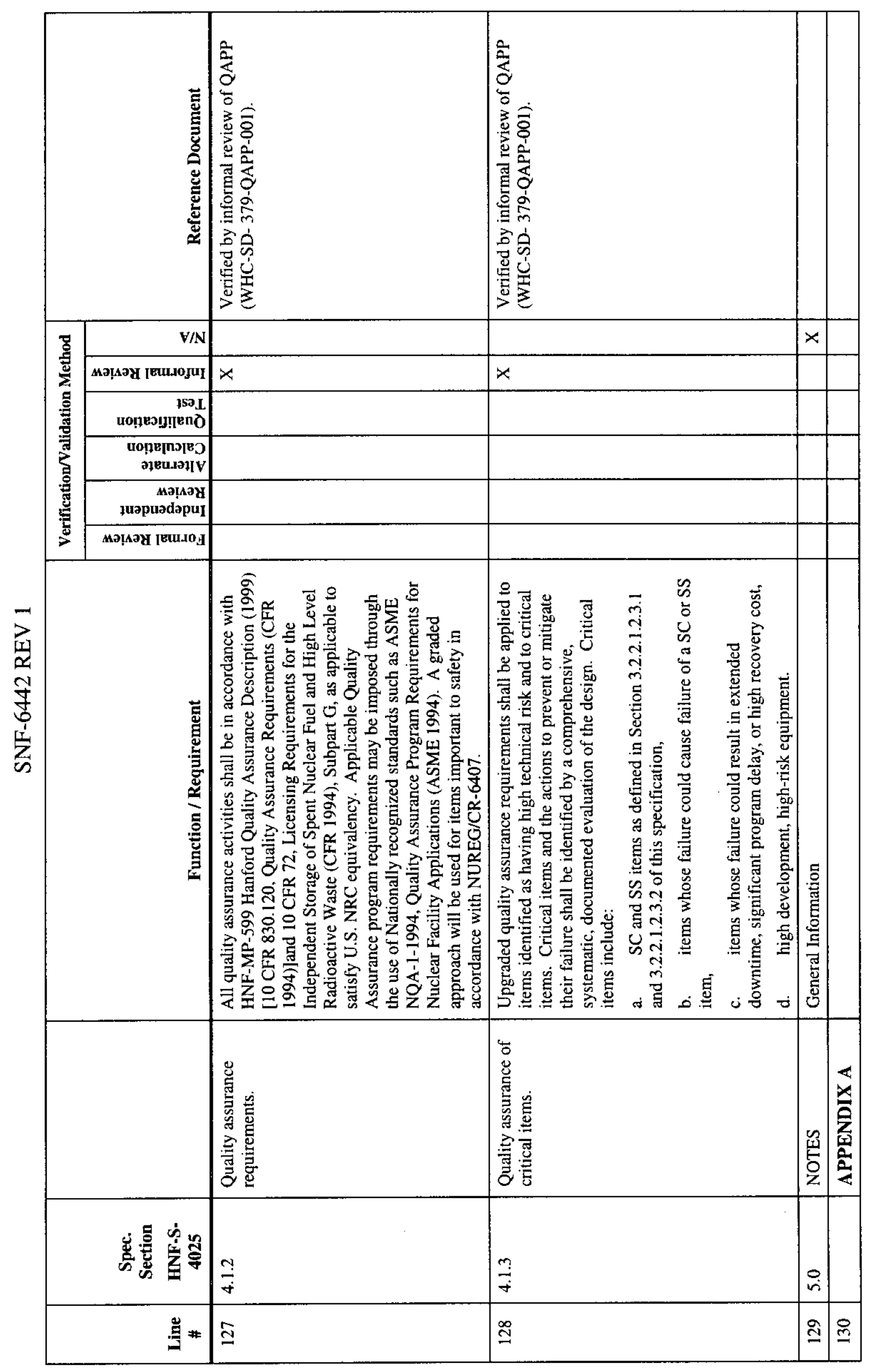




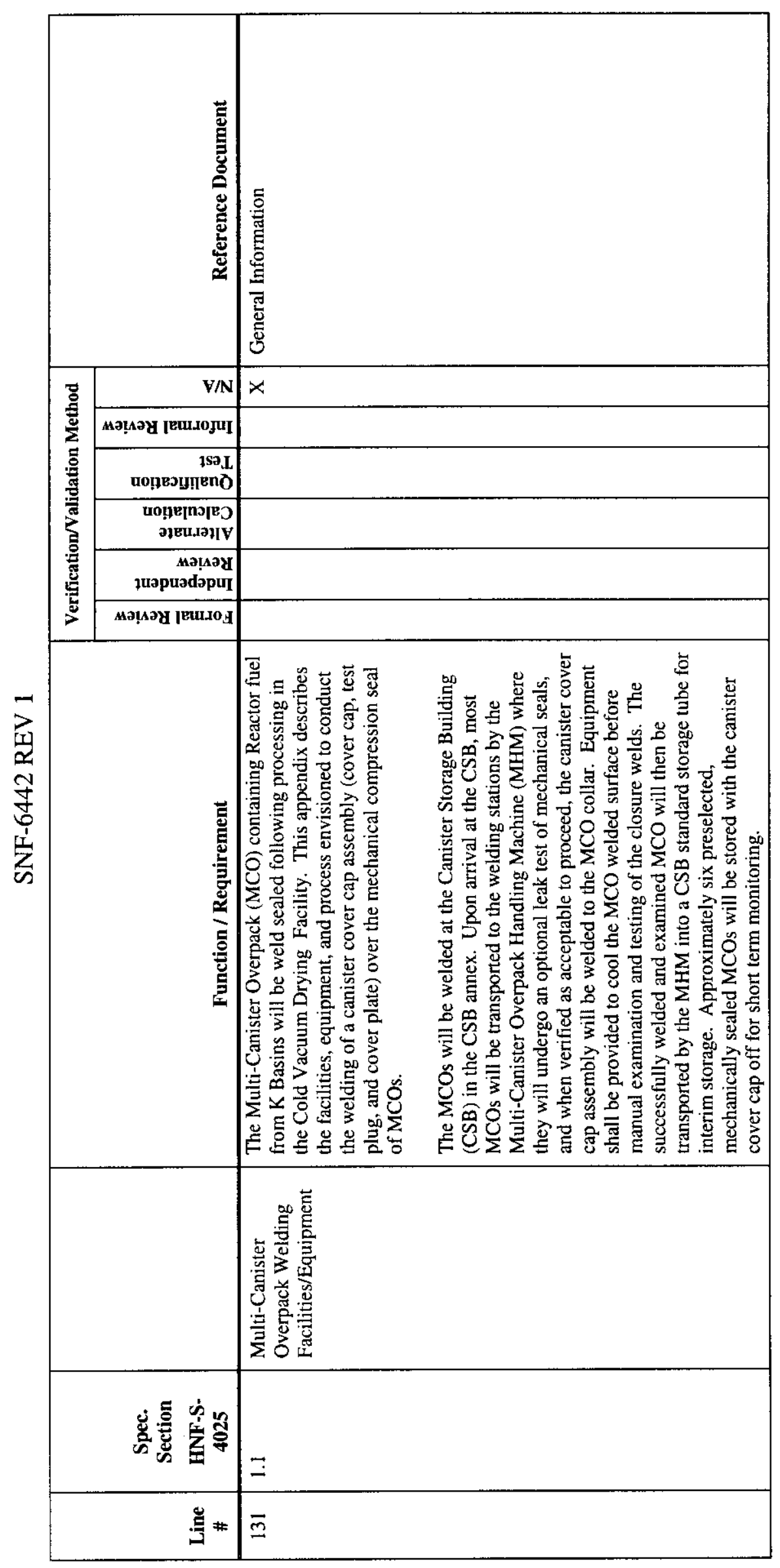




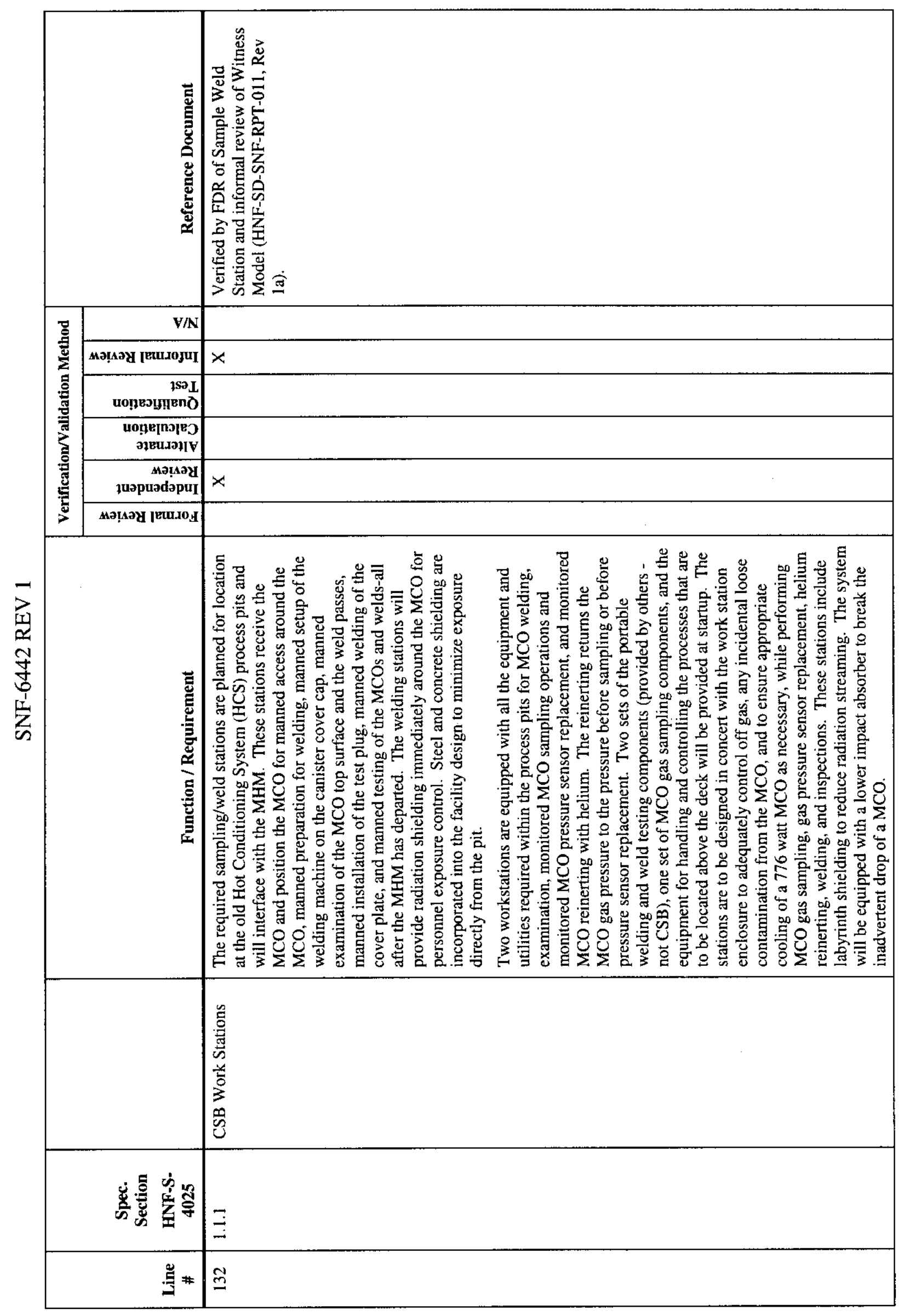




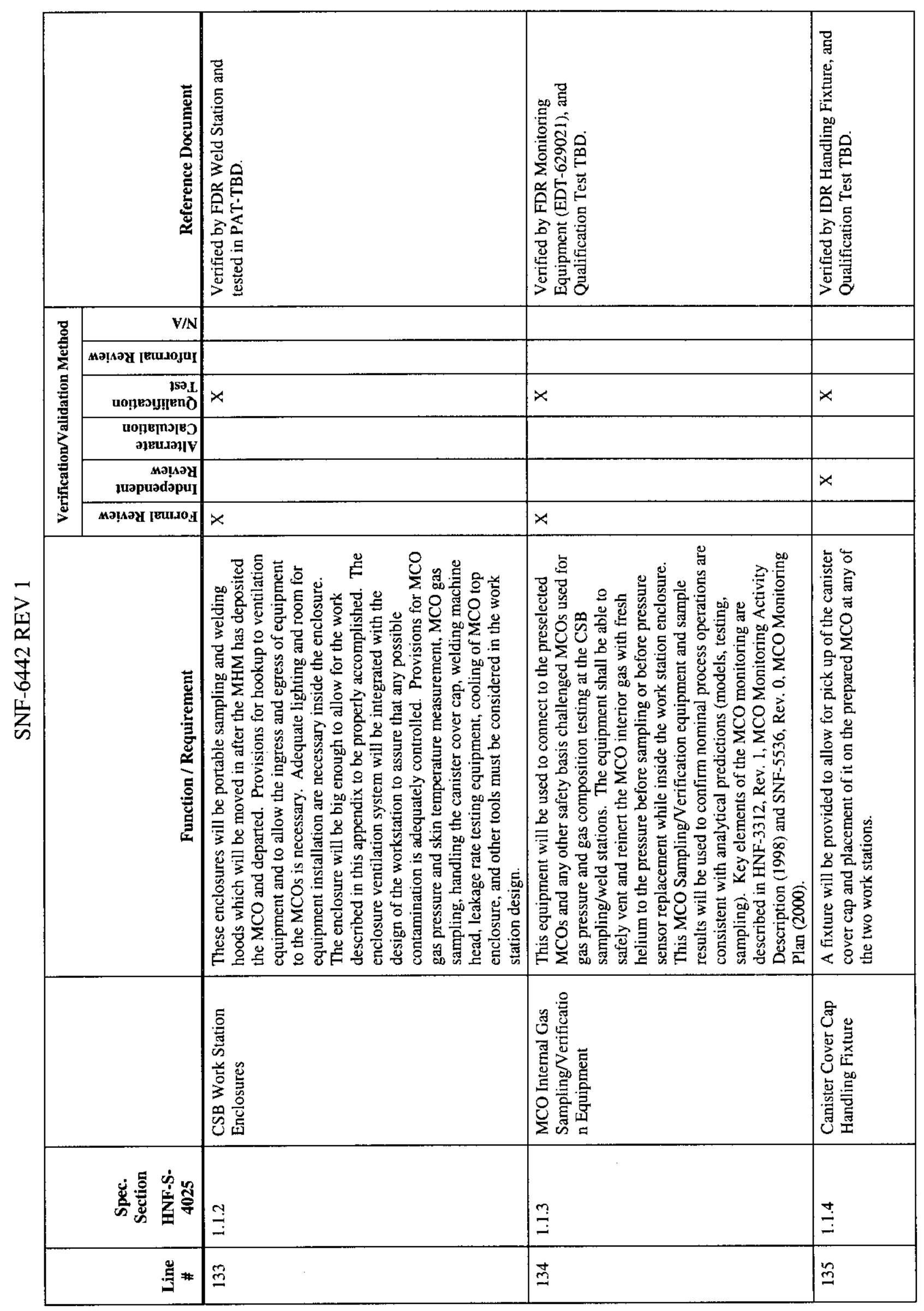




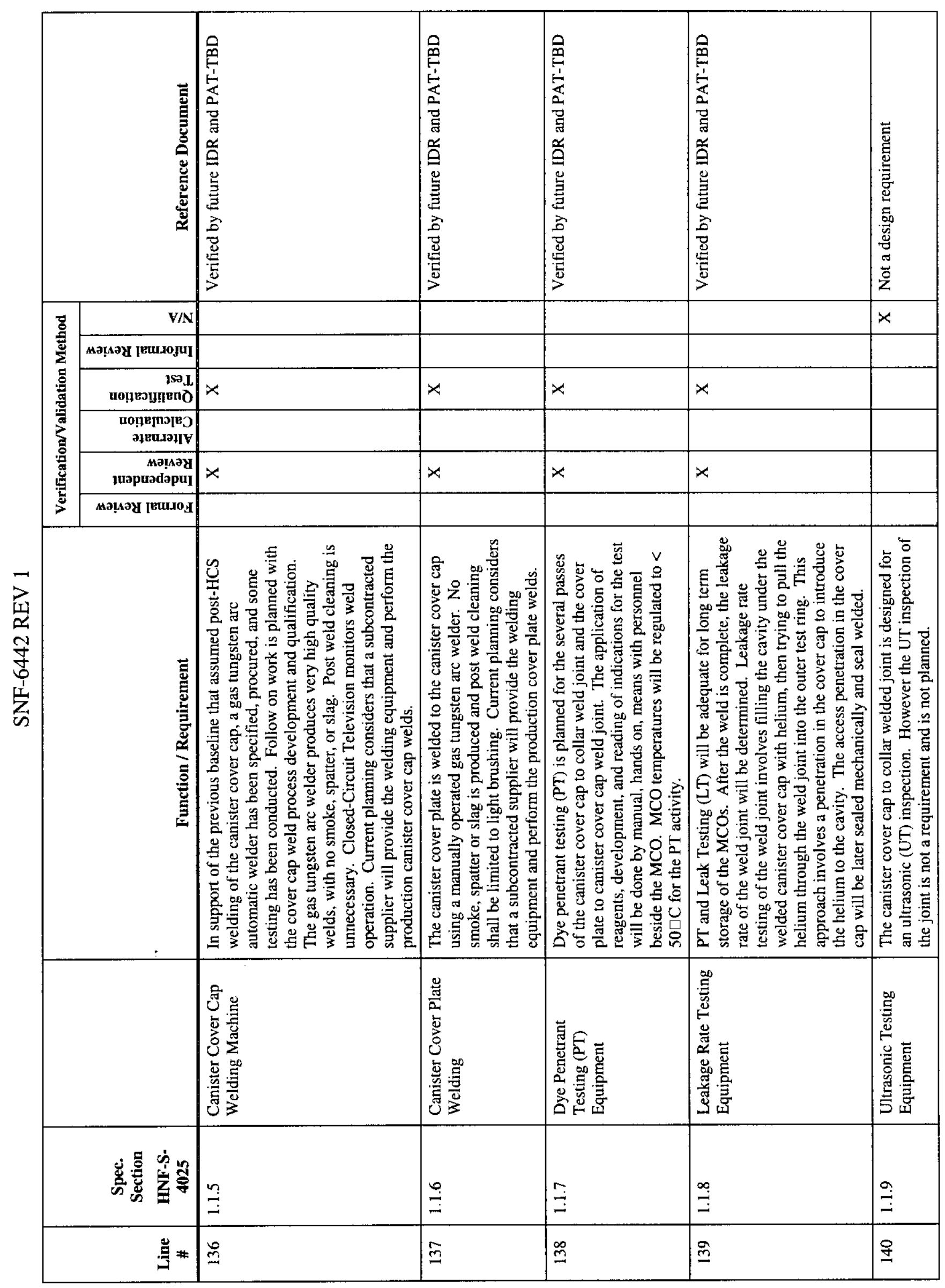




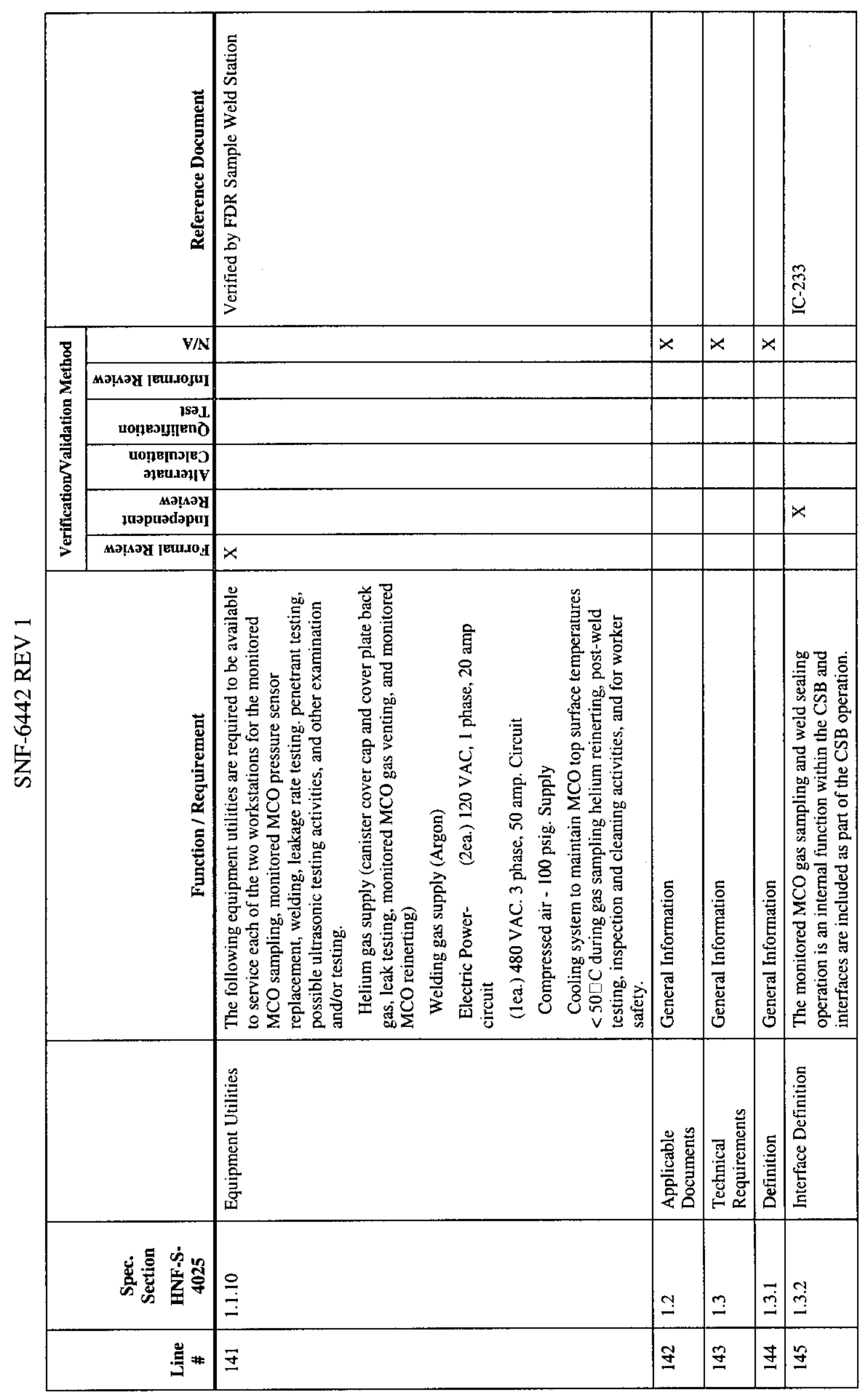




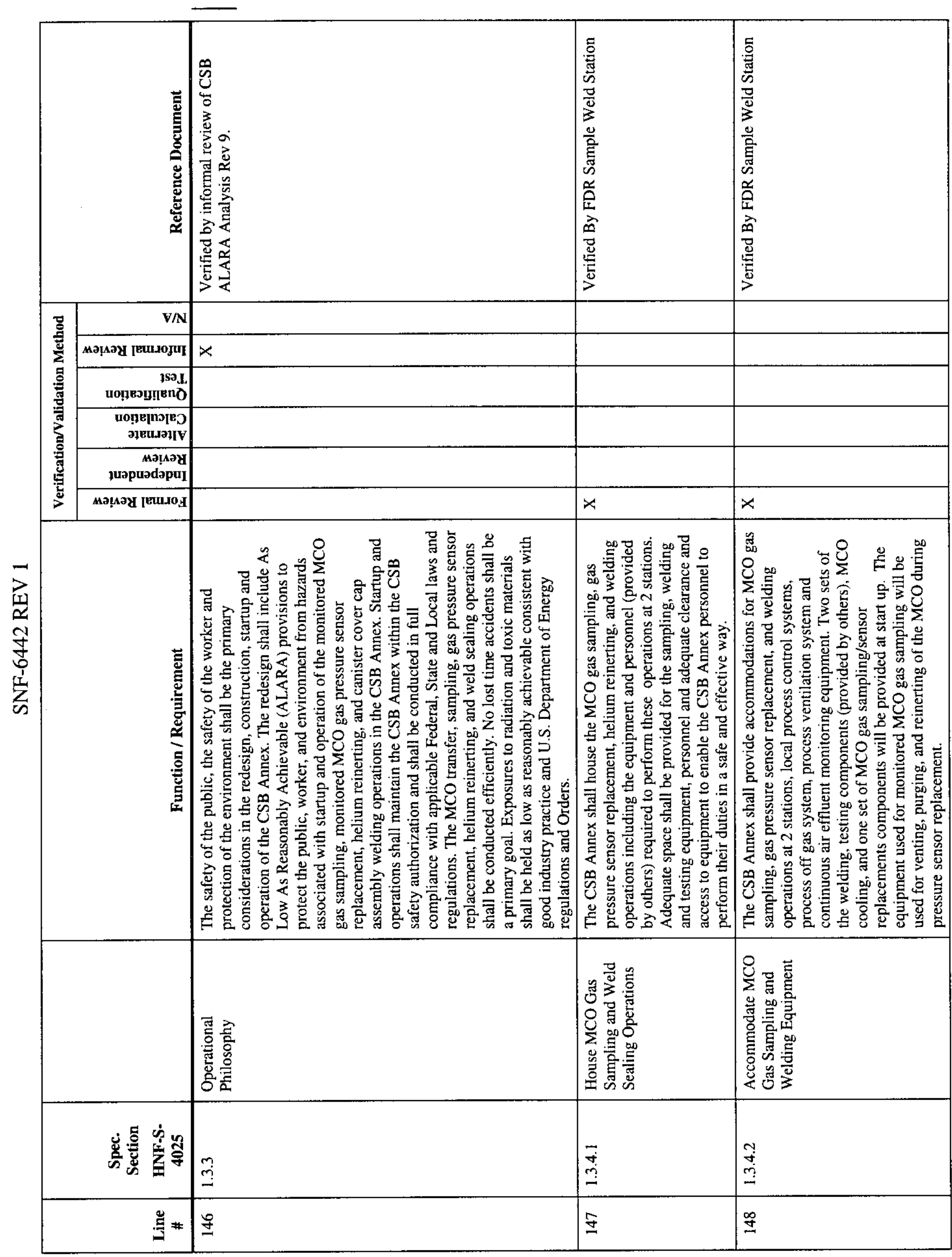




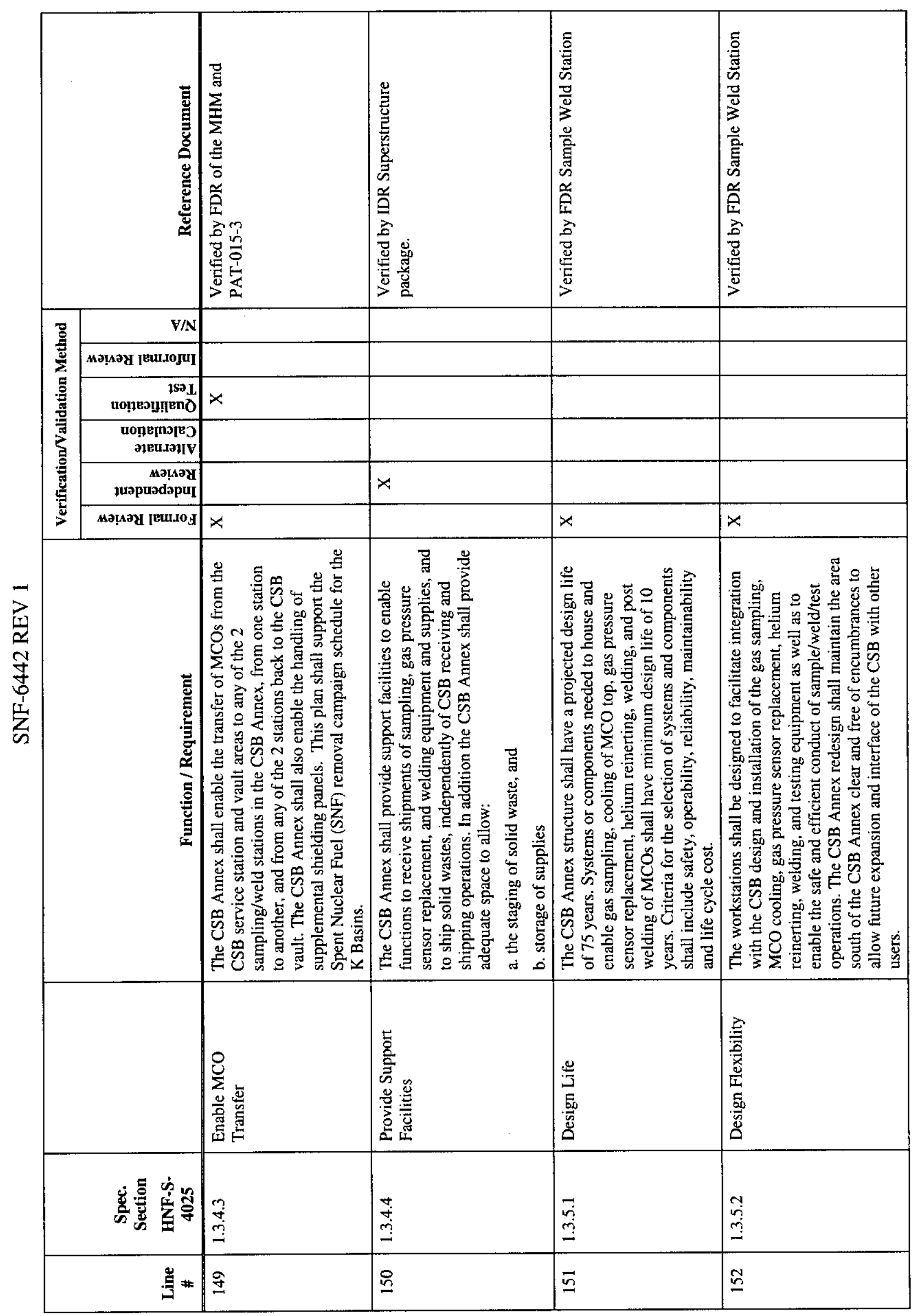




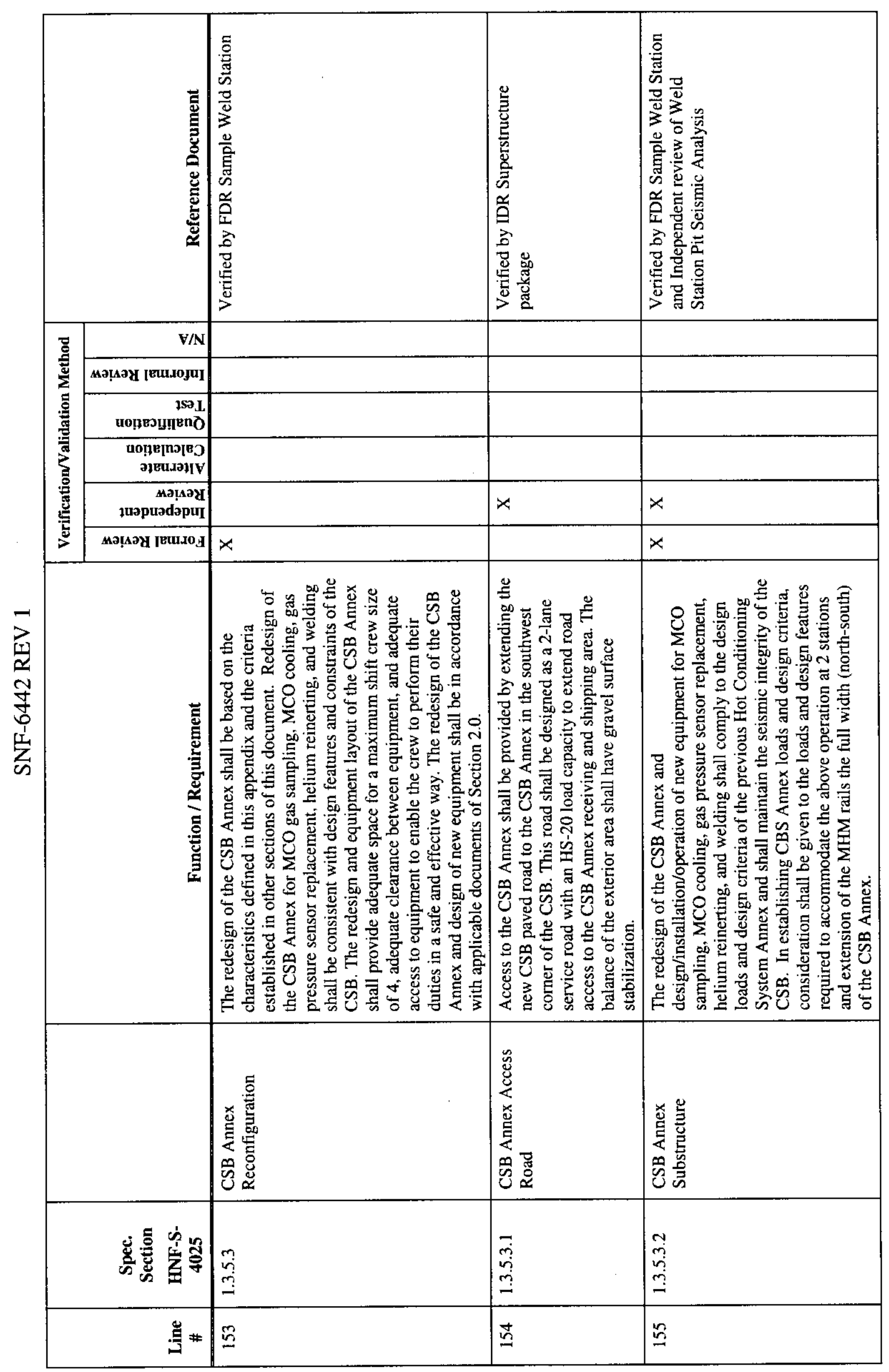




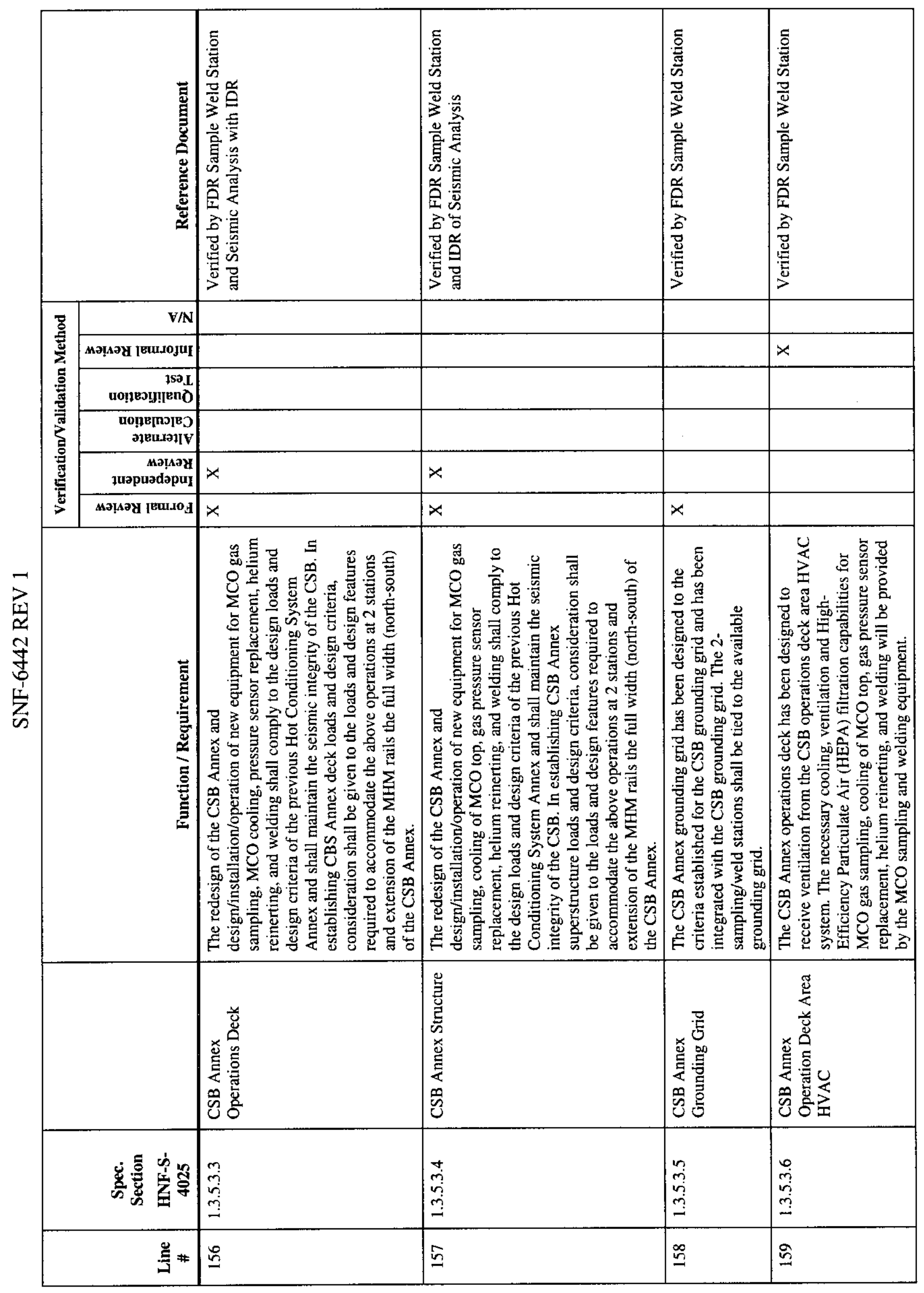




\begin{tabular}{|c|c|c|c|c|c|c|}
\hline 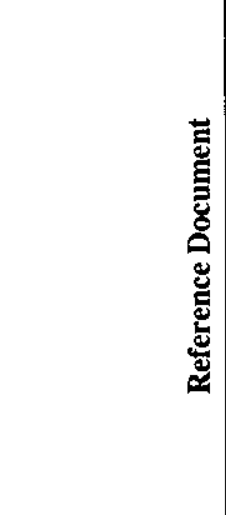 & 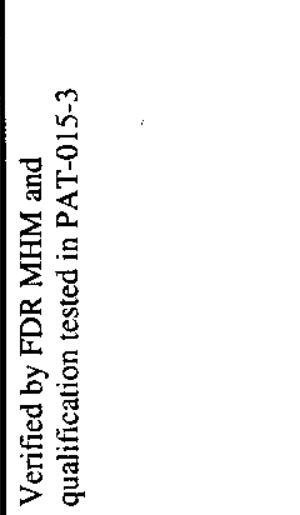 & 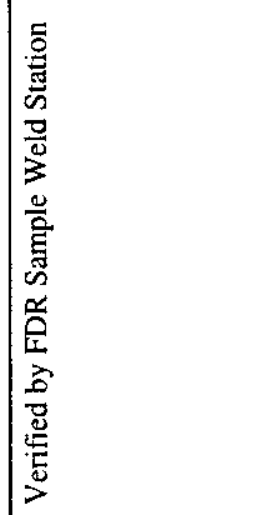 & 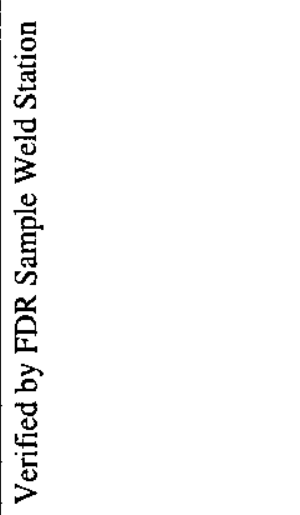 & 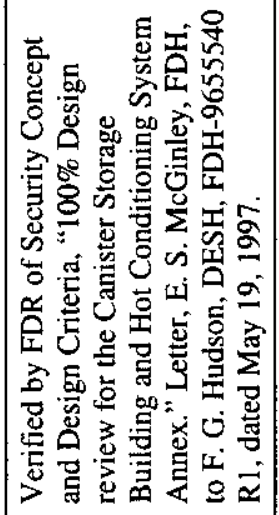 & 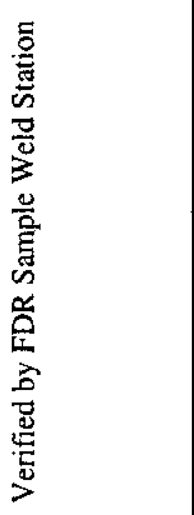 & 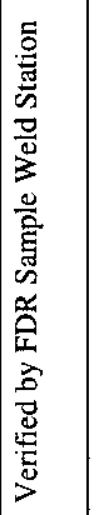 \\
\hline \begin{tabular}{|r|}
$\mathrm{VNN}$ \\
\end{tabular} & & & & & & \\
\hline 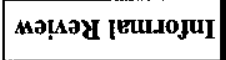 & & & & & & \\
\hline 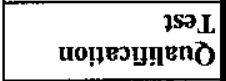 & $x$ & & & & & \\
\hline 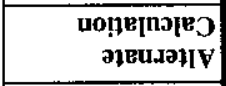 & & & & & & \\
\hline 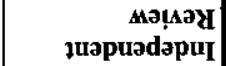 & & & & & & \\
\hline мамару гешло & $x$ & $x$ & $x$ & $x$ & $x$ & $x$ \\
\hline 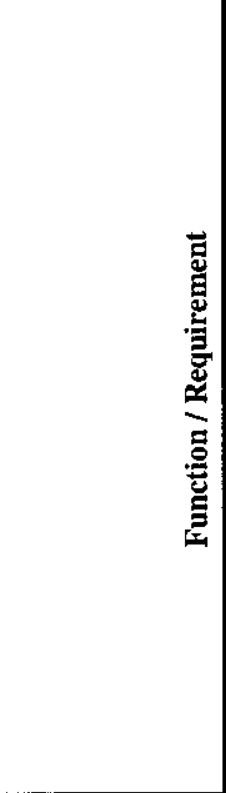 & 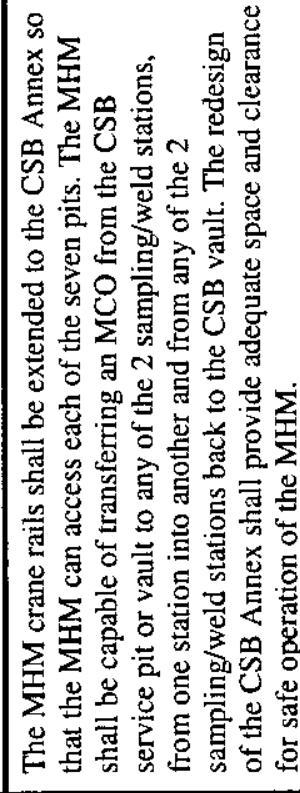 & 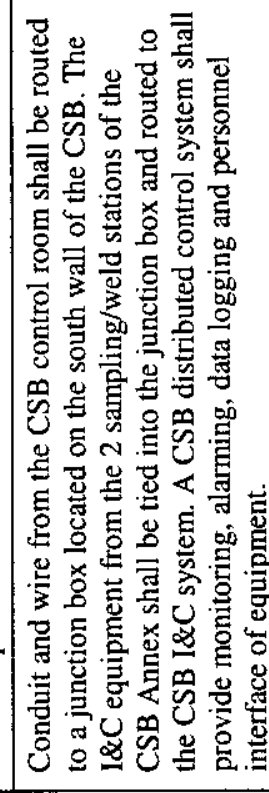 & 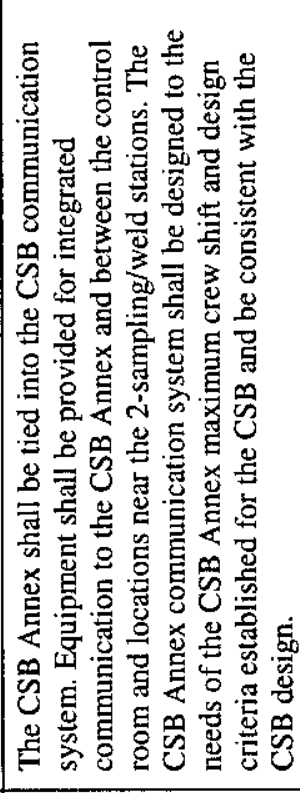 & 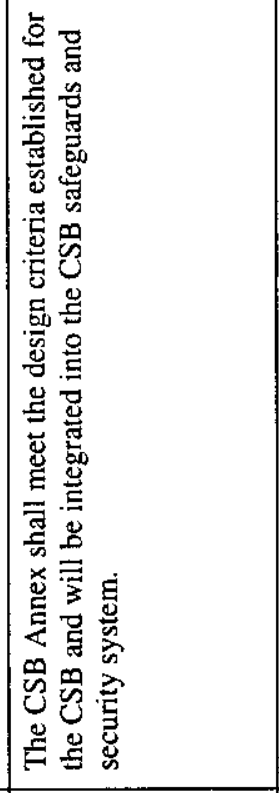 & 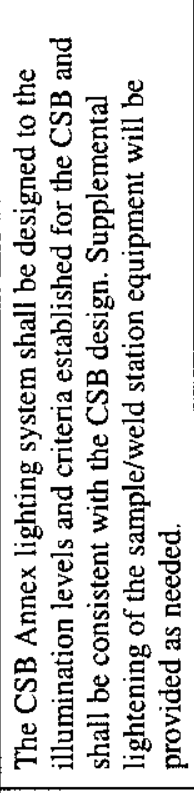 & 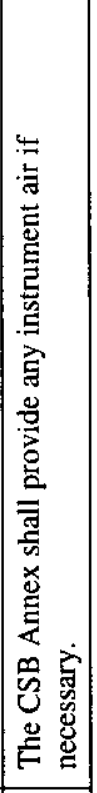 \\
\hline & 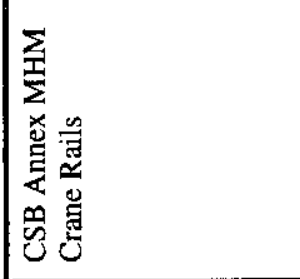 & 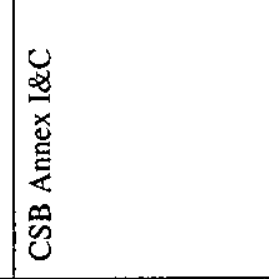 & 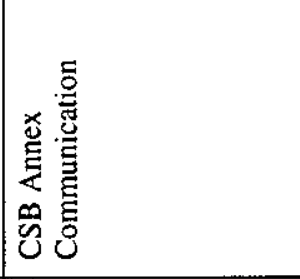 & 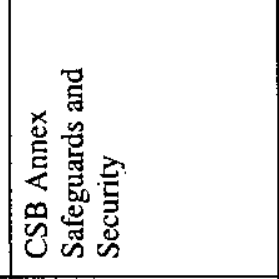 & 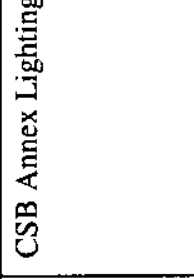 & 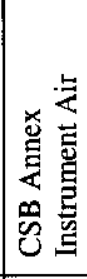 \\
\hline 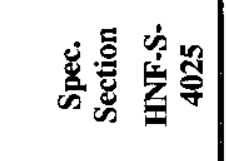 & 20. & 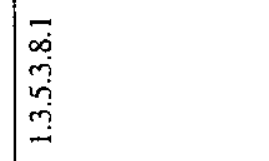 & $\mid$ & $\mid$ & 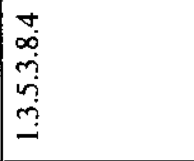 & 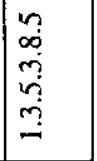 \\
\hline$\stackrel{g}{g} *$ & $\underline{9}$ & $\underline{\underline{\sigma}}$ & $\tilde{\sigma}$ & $\underline{6}$ & f & $\because$ \\
\hline
\end{tabular}




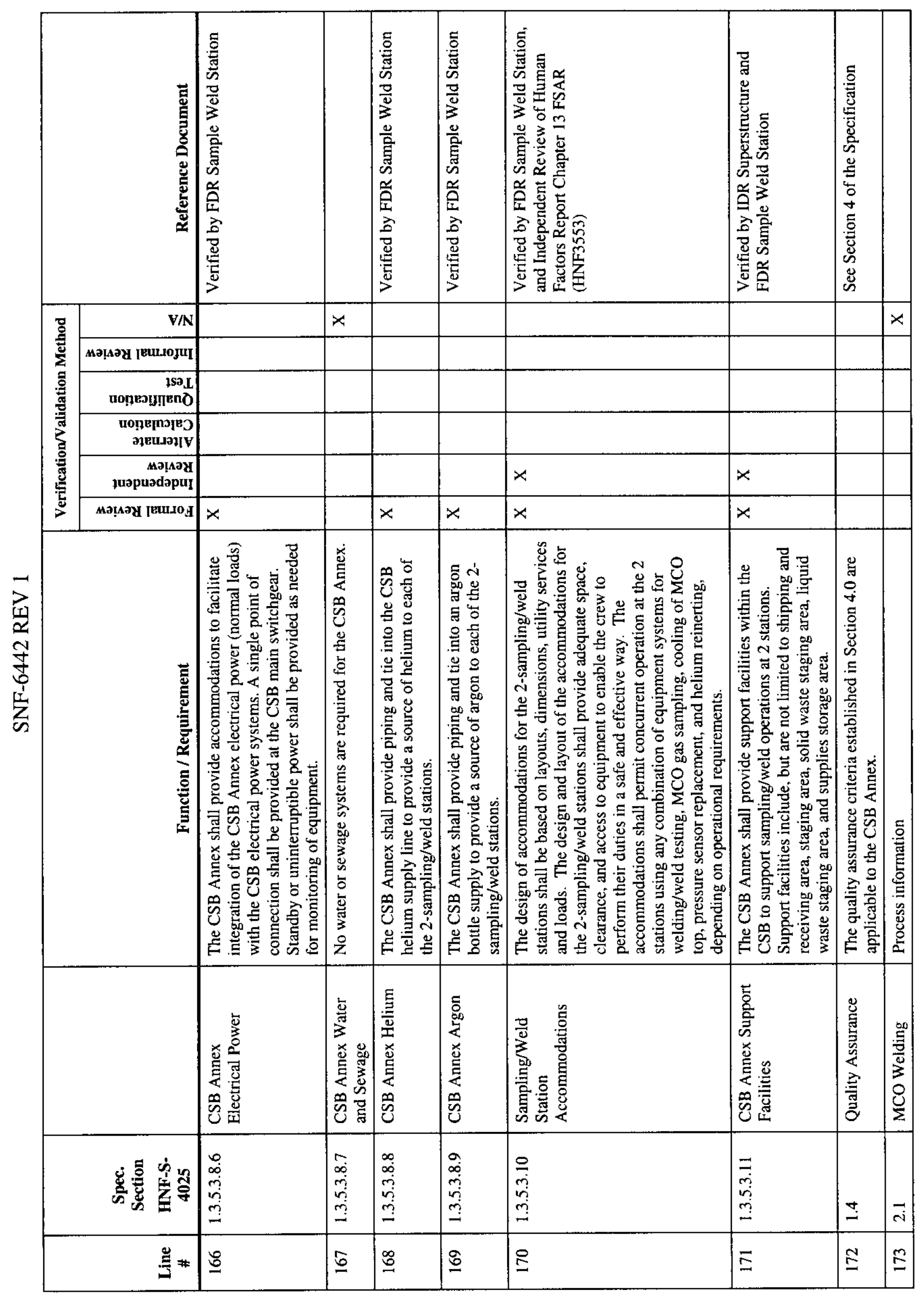

ต 


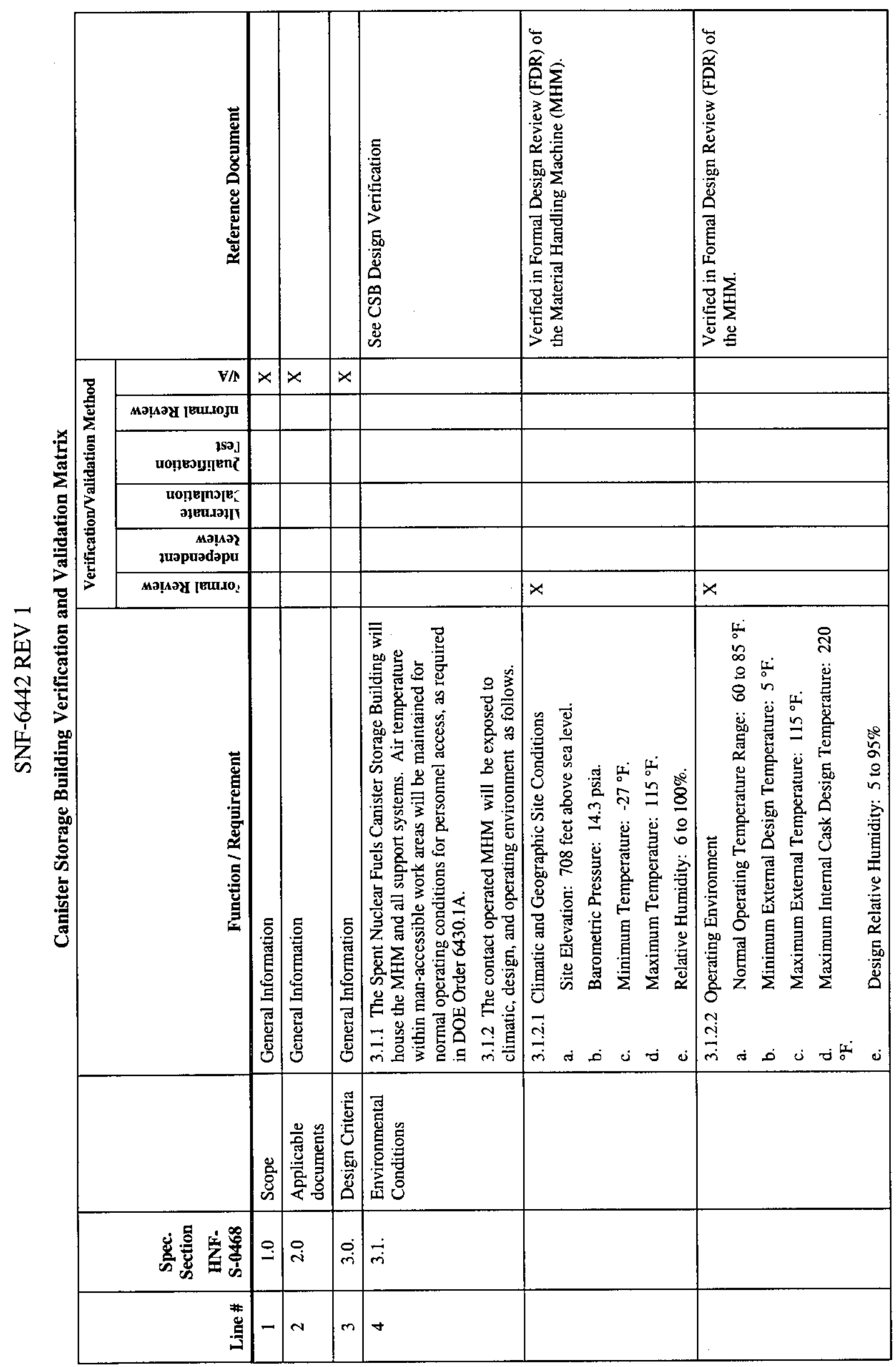

$\stackrel{N}{n}$ 


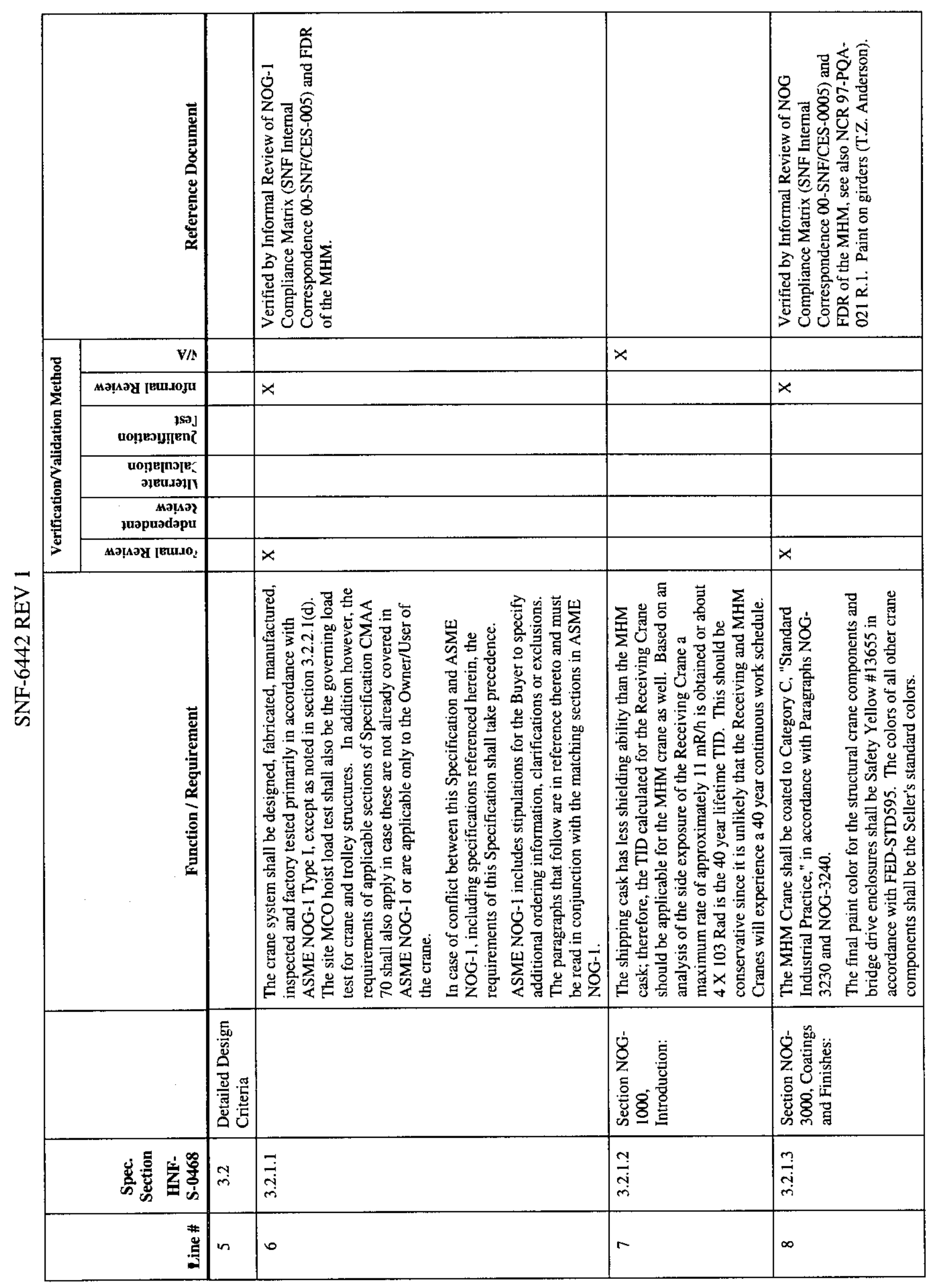

$\frac{m}{n}$ 


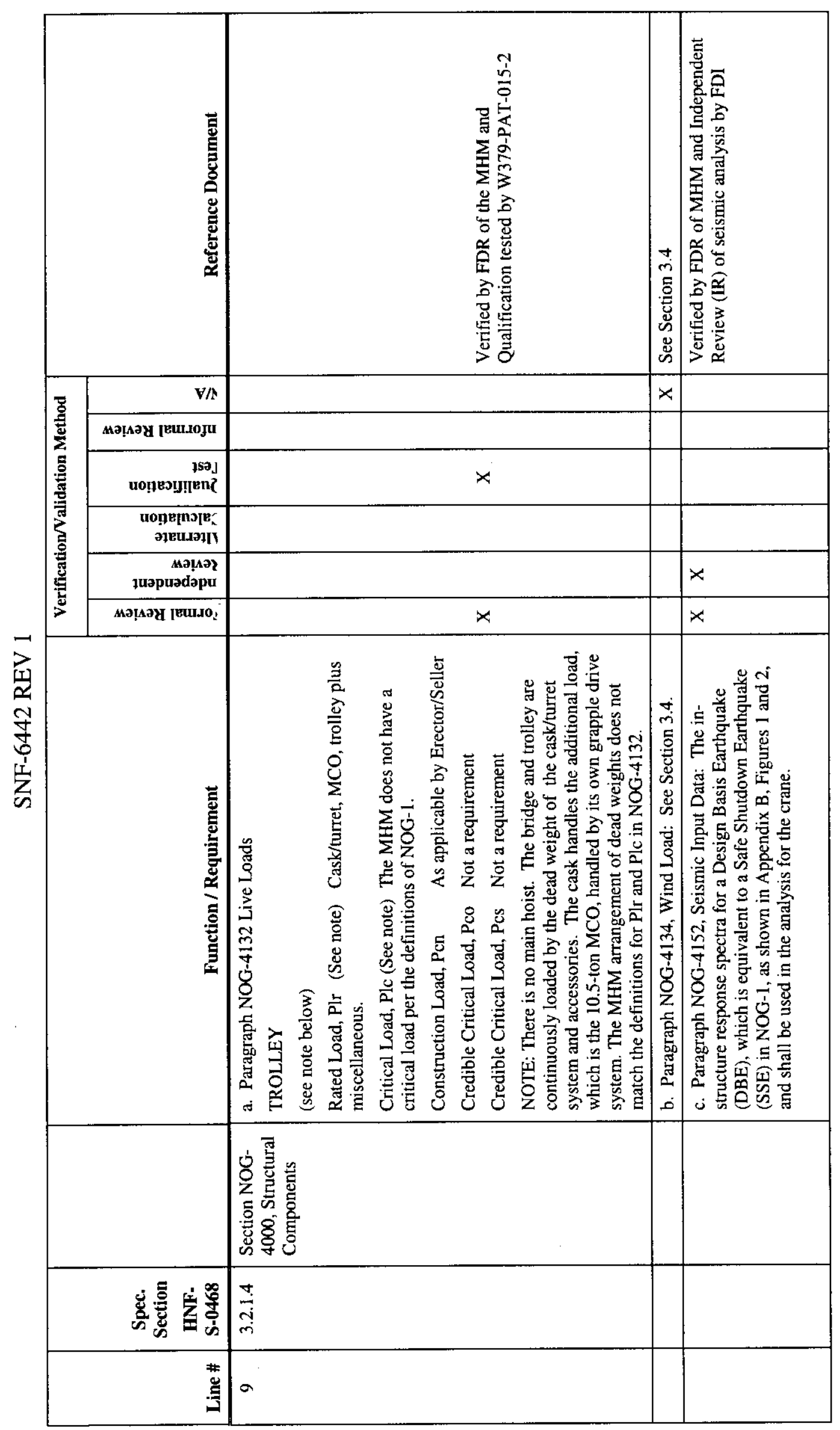

$\frac{7}{n}$ 


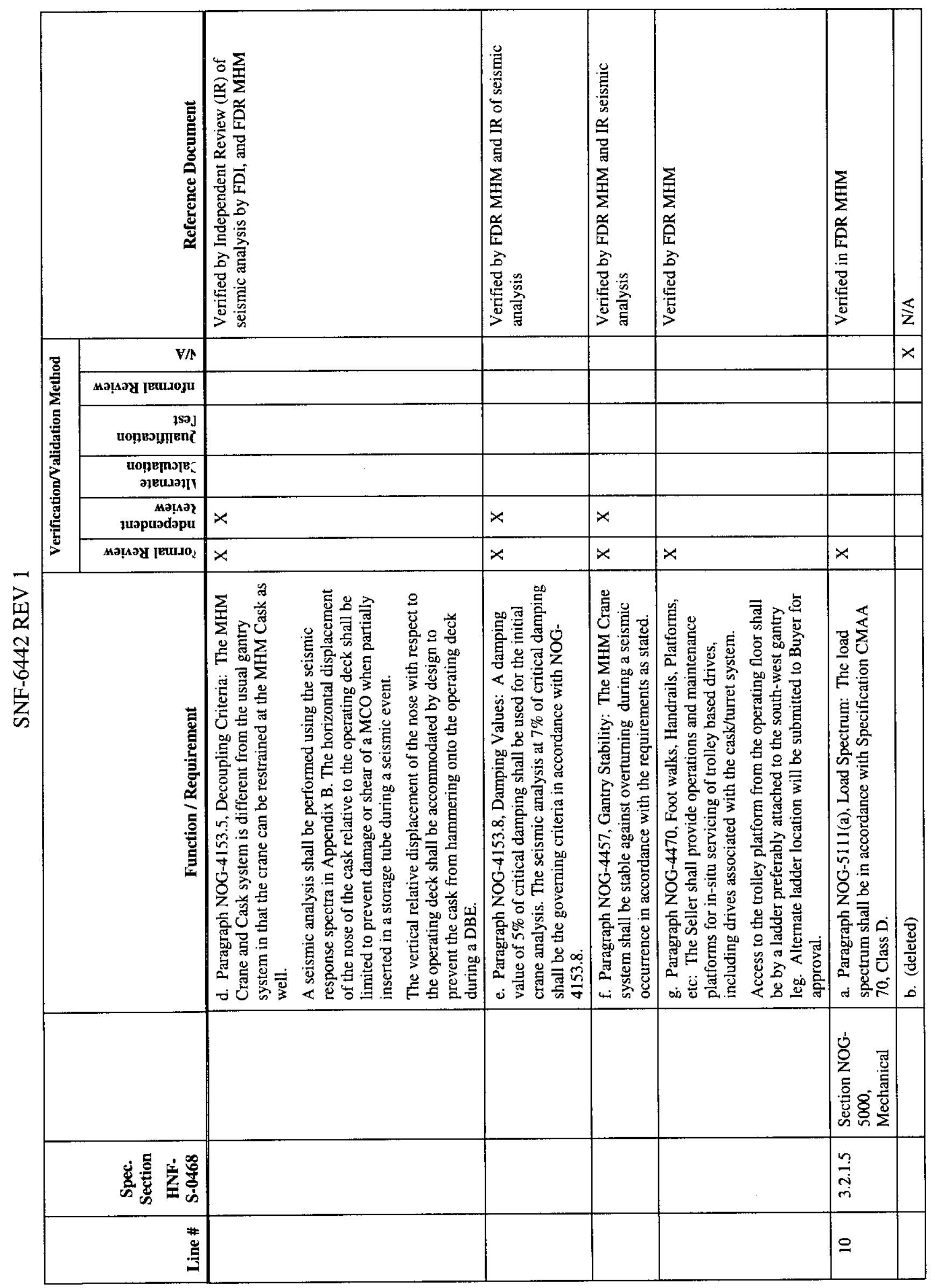




\begin{tabular}{|c|c|c|c|c|c|c|c|c|c|c|}
\hline & 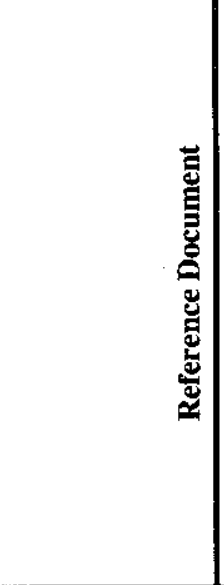 & 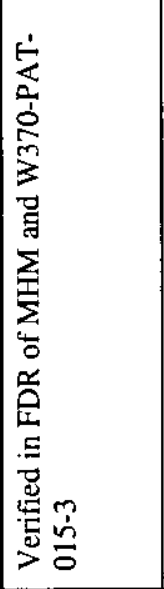 & 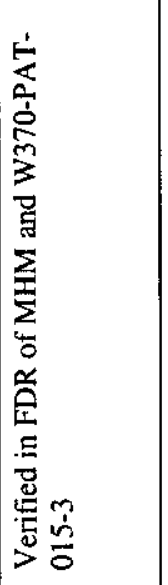 & 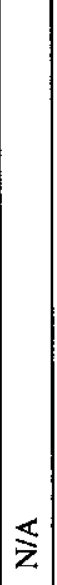 & $\frac{\pi}{z}$ & $\frac{s}{z}$ & 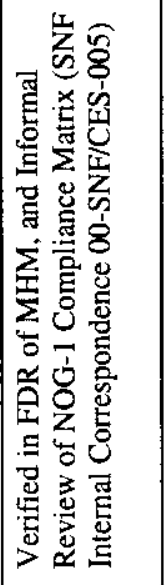 & 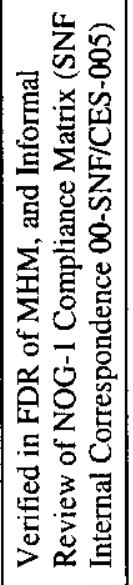 & 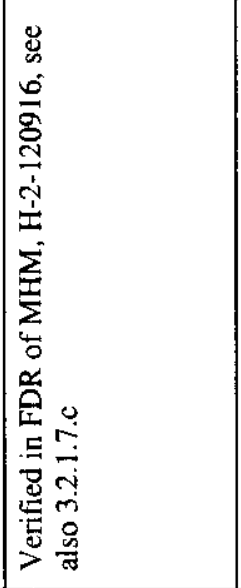 & 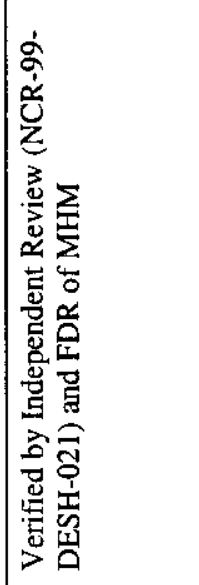 \\
\hline \multirow{6}{*}{ 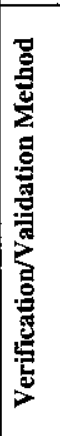 } & v/ & & & $x$ & $x$ & $x$ & & & & \\
\hline & 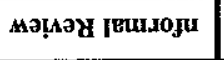 & & & & & & $x$ & $x$ & & \\
\hline & 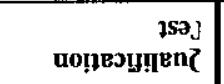 & $x$ & $x$ & & & & & & & \\
\hline & 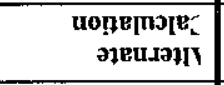 & & & & & & & & & \\
\hline & 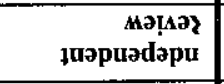 & & & & & & & & & $x$ \\
\hline & мәтару [вицов & $x$ & $x$ & & & & $x$ & $x$ & $x$ & $x$ \\
\hline \multirow{2}{*}{\multicolumn{2}{|c|}{ 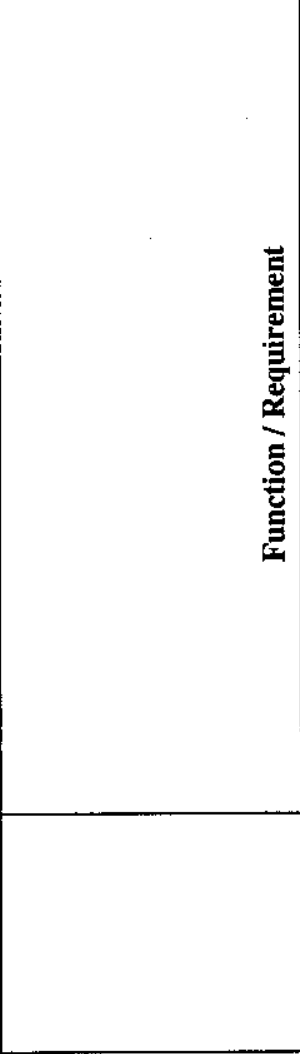 }} & 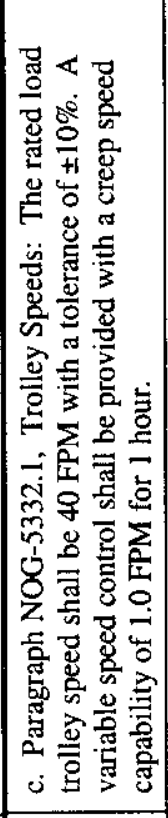 & 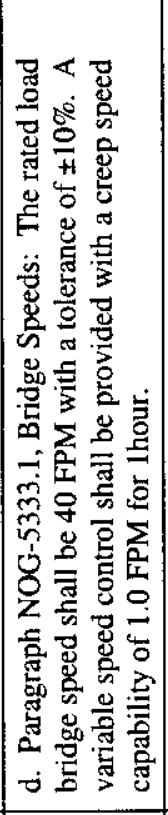 & 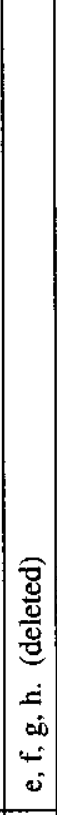 & 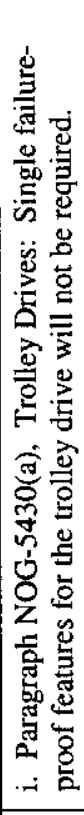 & 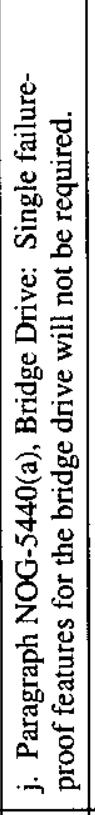 & 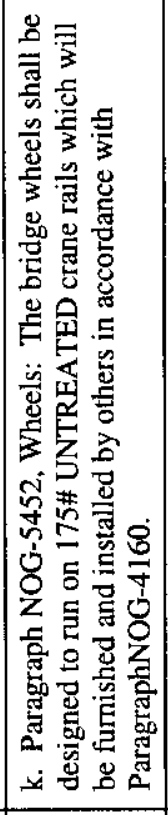 & 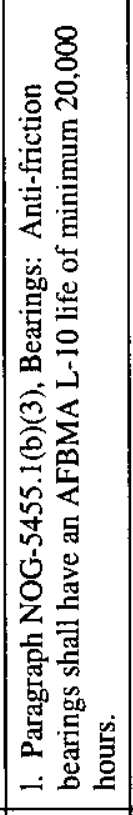 & 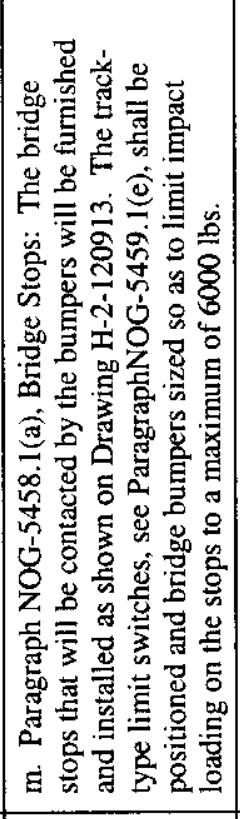 & 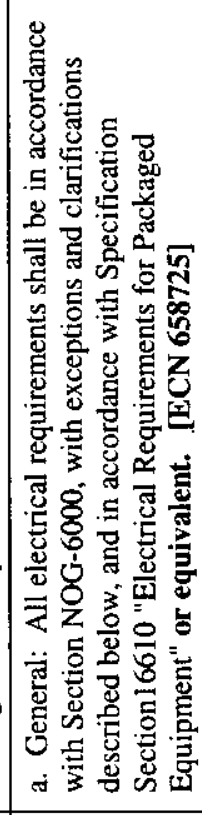 \\
\hline & & & & & & & & & & 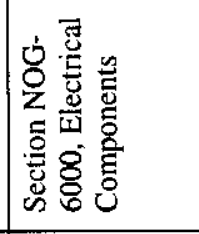 \\
\hline & 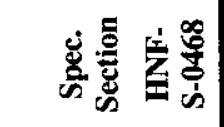 & & & & & & & & & 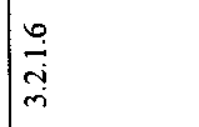 \\
\hline & 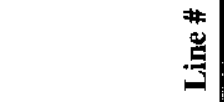 & & & & & & & & & $=$ \\
\hline
\end{tabular}




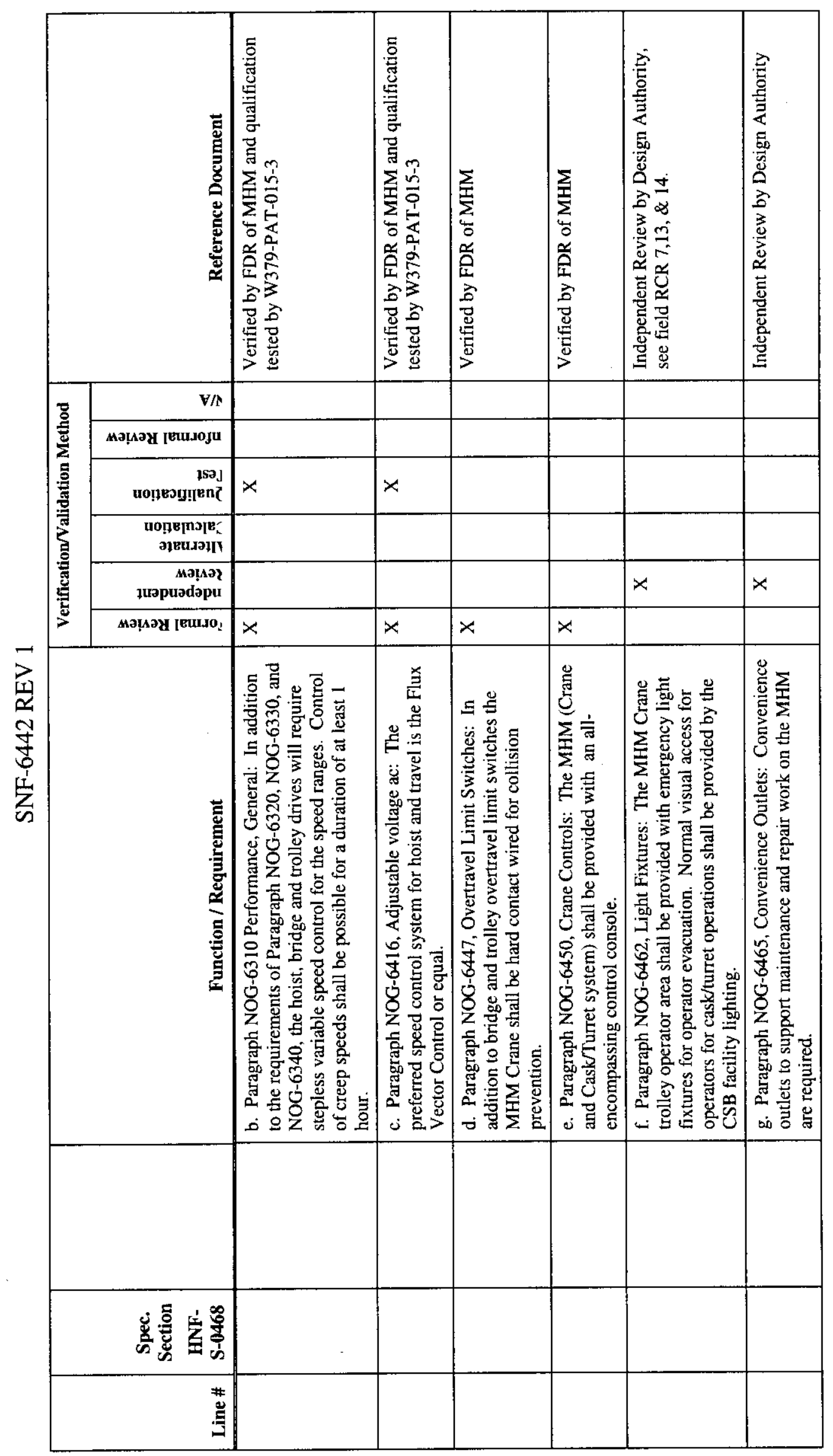

$\frac{1}{1}$ 


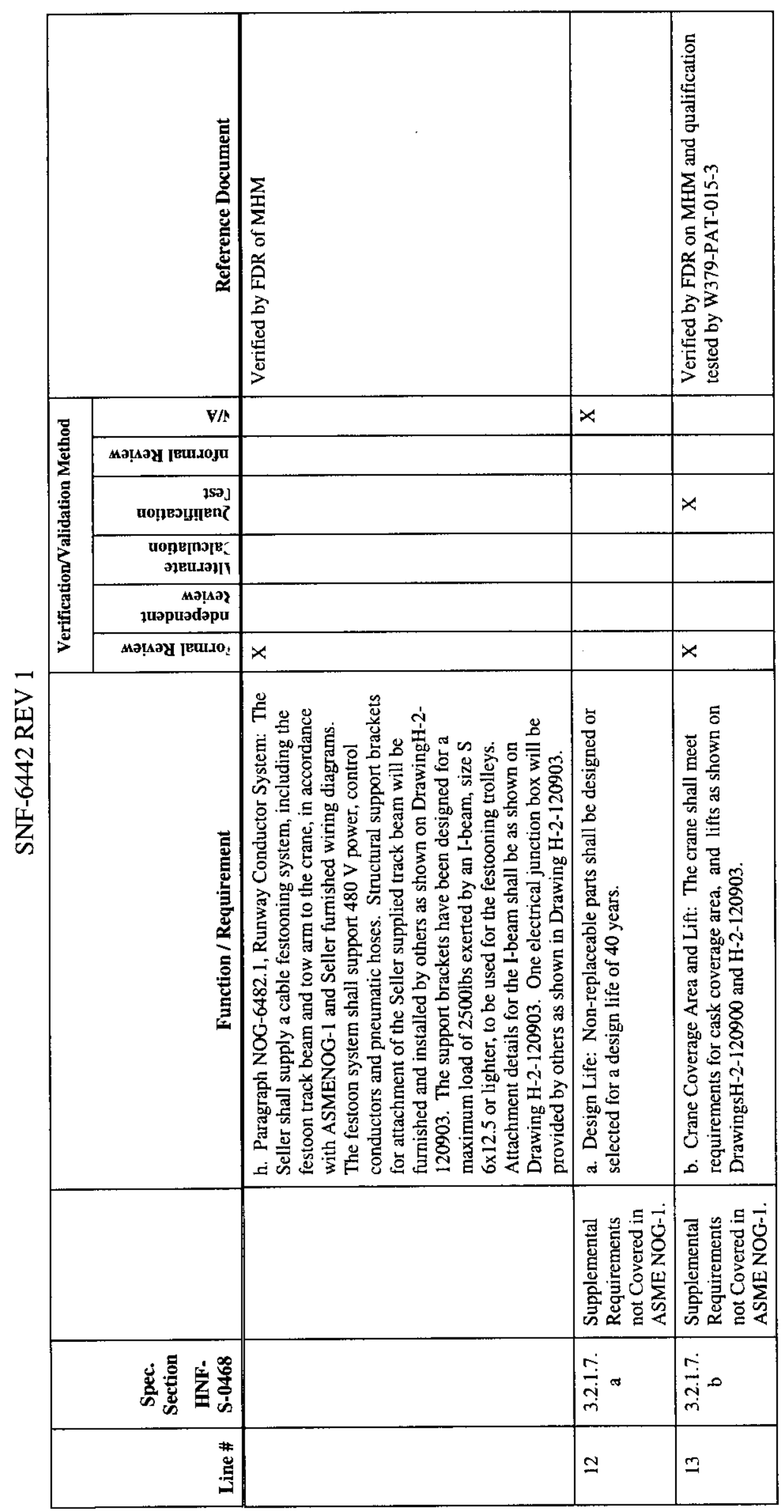

$\frac{\infty}{n}$ 


\begin{tabular}{|c|c|c|}
\hline 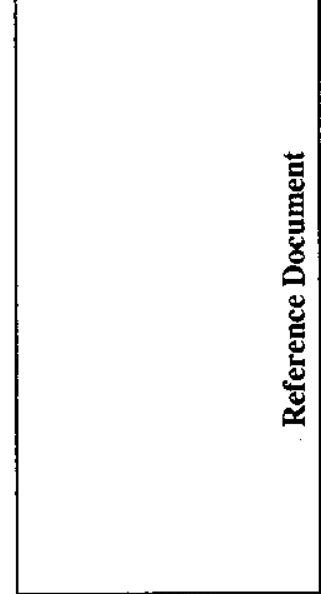 & 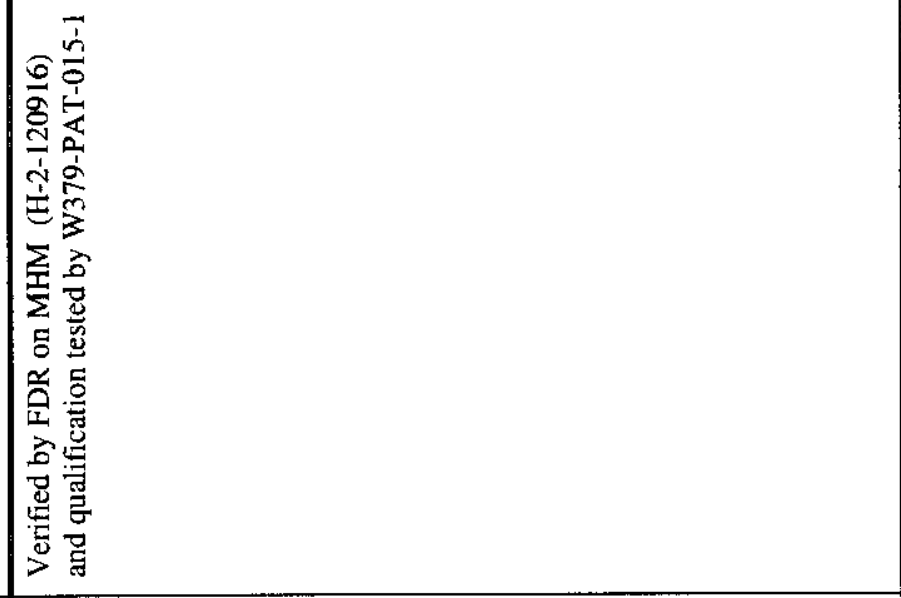 & 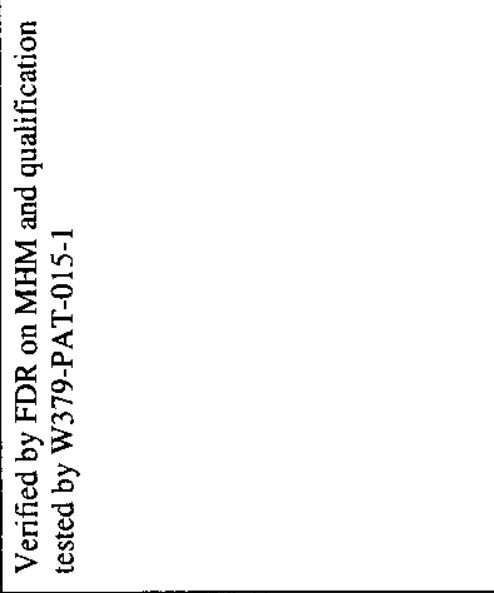 \\
\hline $\mathrm{v} / \mathrm{s}$ & & \\
\hline мәрату ןеш.оји & & \\
\hline 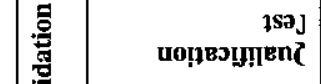 & $x$ & $x$ \\
\hline 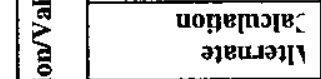 & & \\
\hline 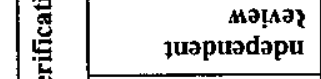 & & \\
\hline мәрау бешшо & $x$ & $x$ \\
\hline \multirow[t]{2}{*}{ لّيّة } & 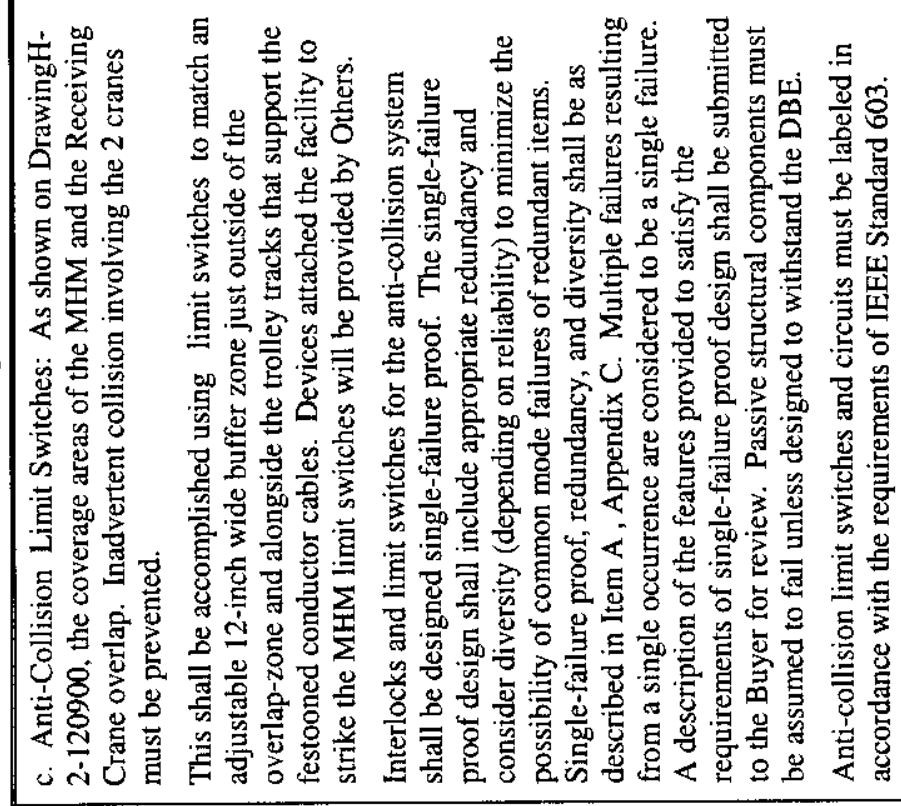 & 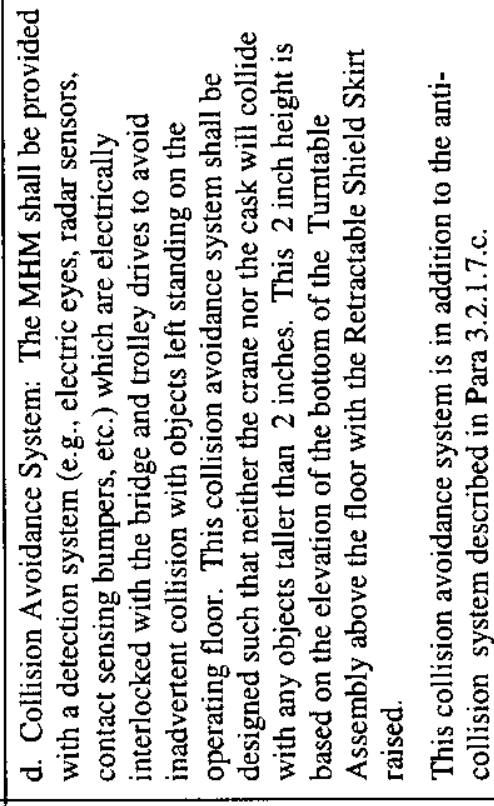 \\
\hline & 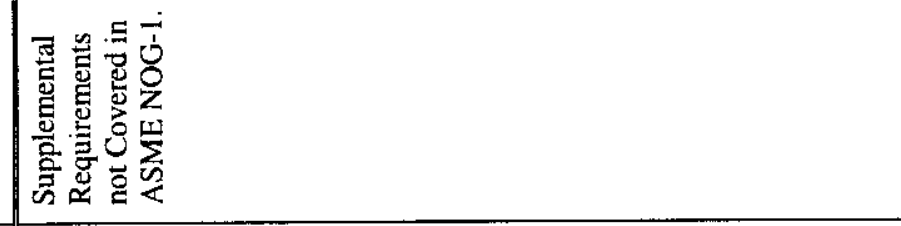 & 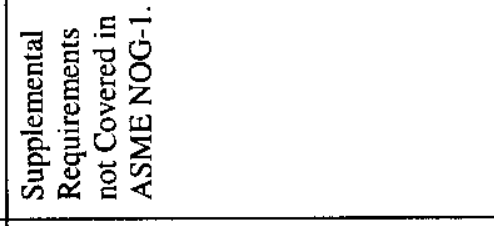 \\
\hline 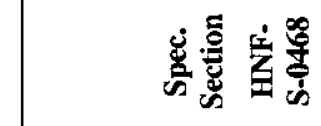 & $\underset{\dot{\vec{j}}}{\vec{m}}$ & $\begin{array}{l}\dot{\vec{j}} \\
\dot{\vec{j}} \\
\dot{m}\end{array}$ \\
\hline & \pm & $\cong$ \\
\hline
\end{tabular}

$\frac{9}{1}$ 


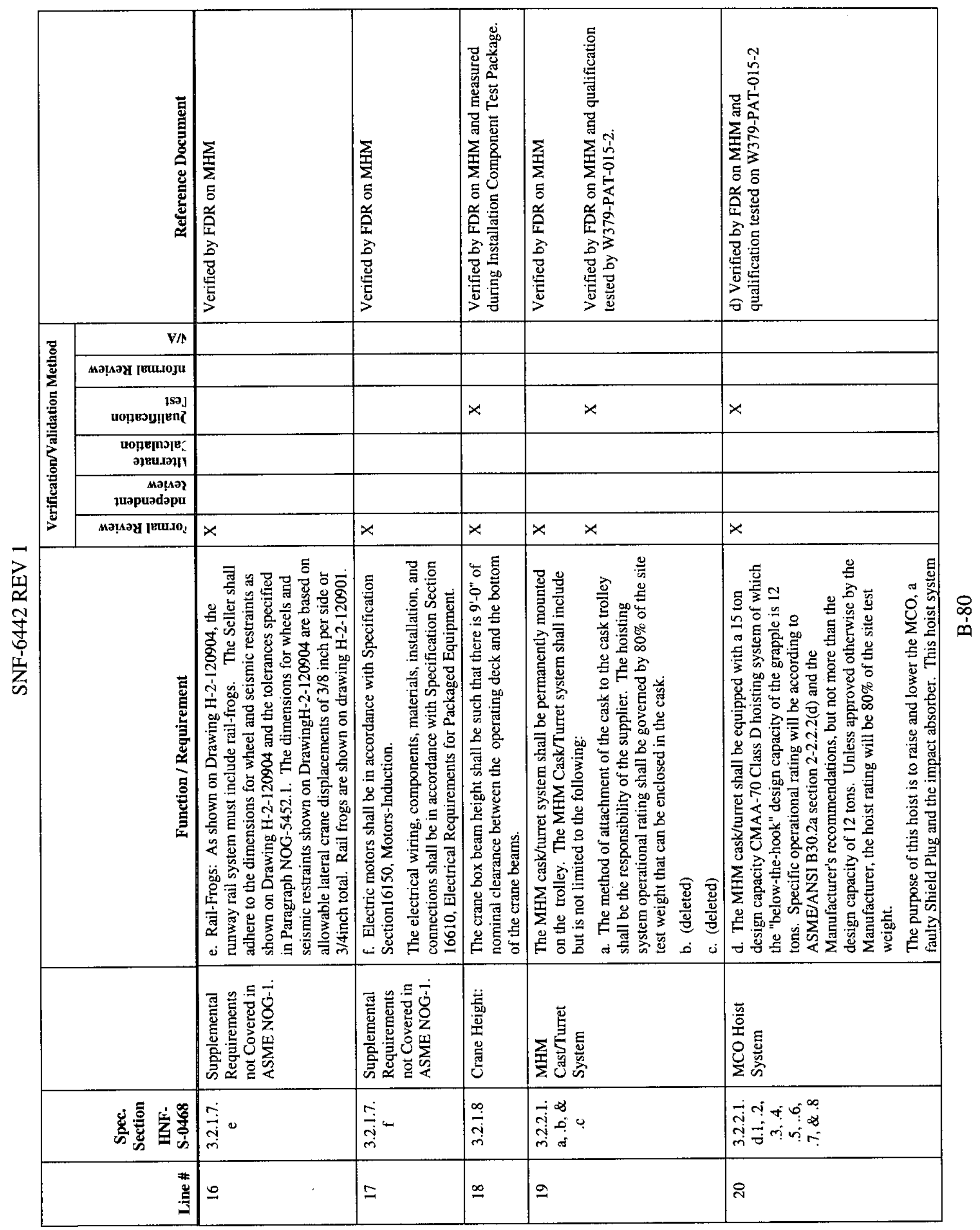




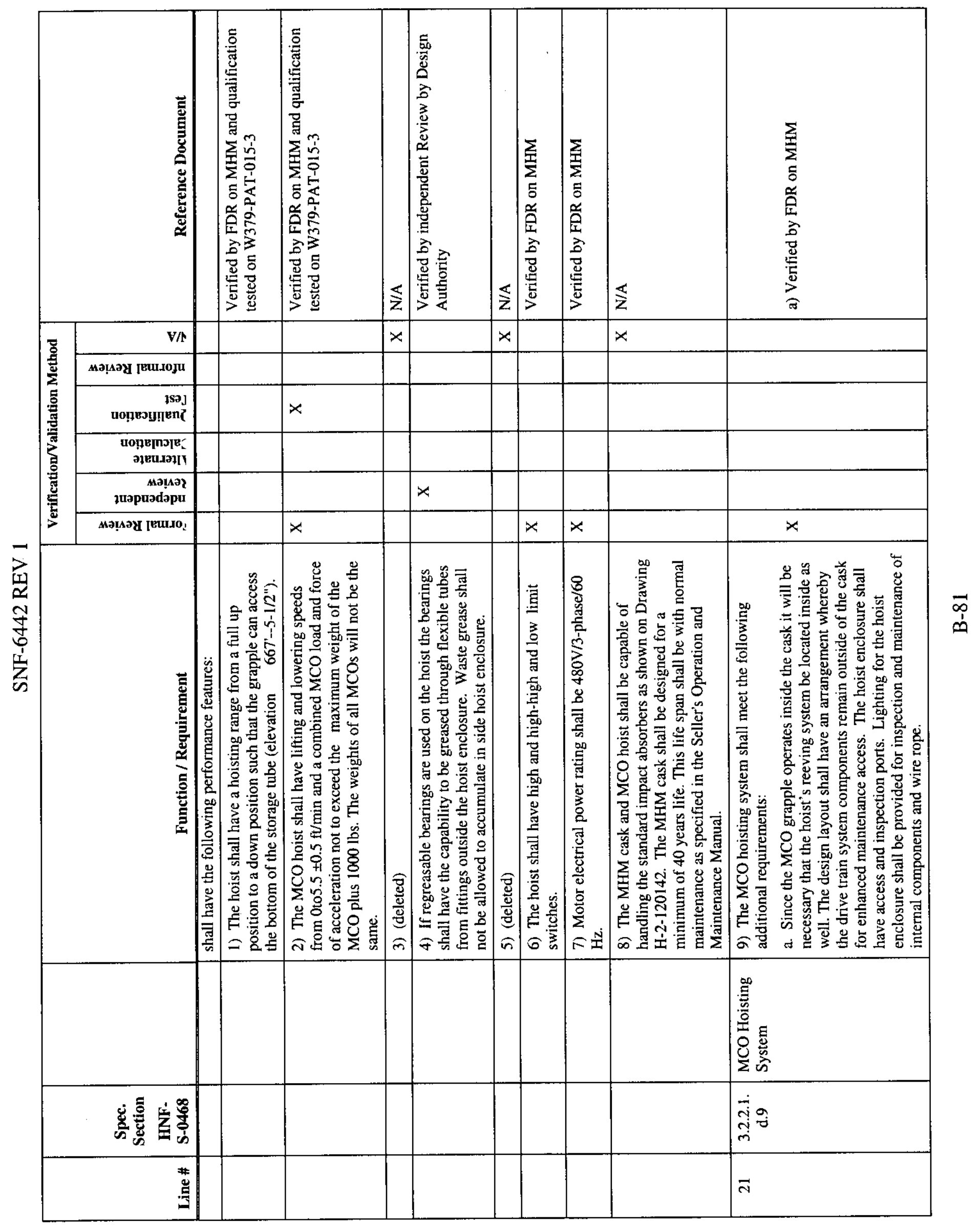




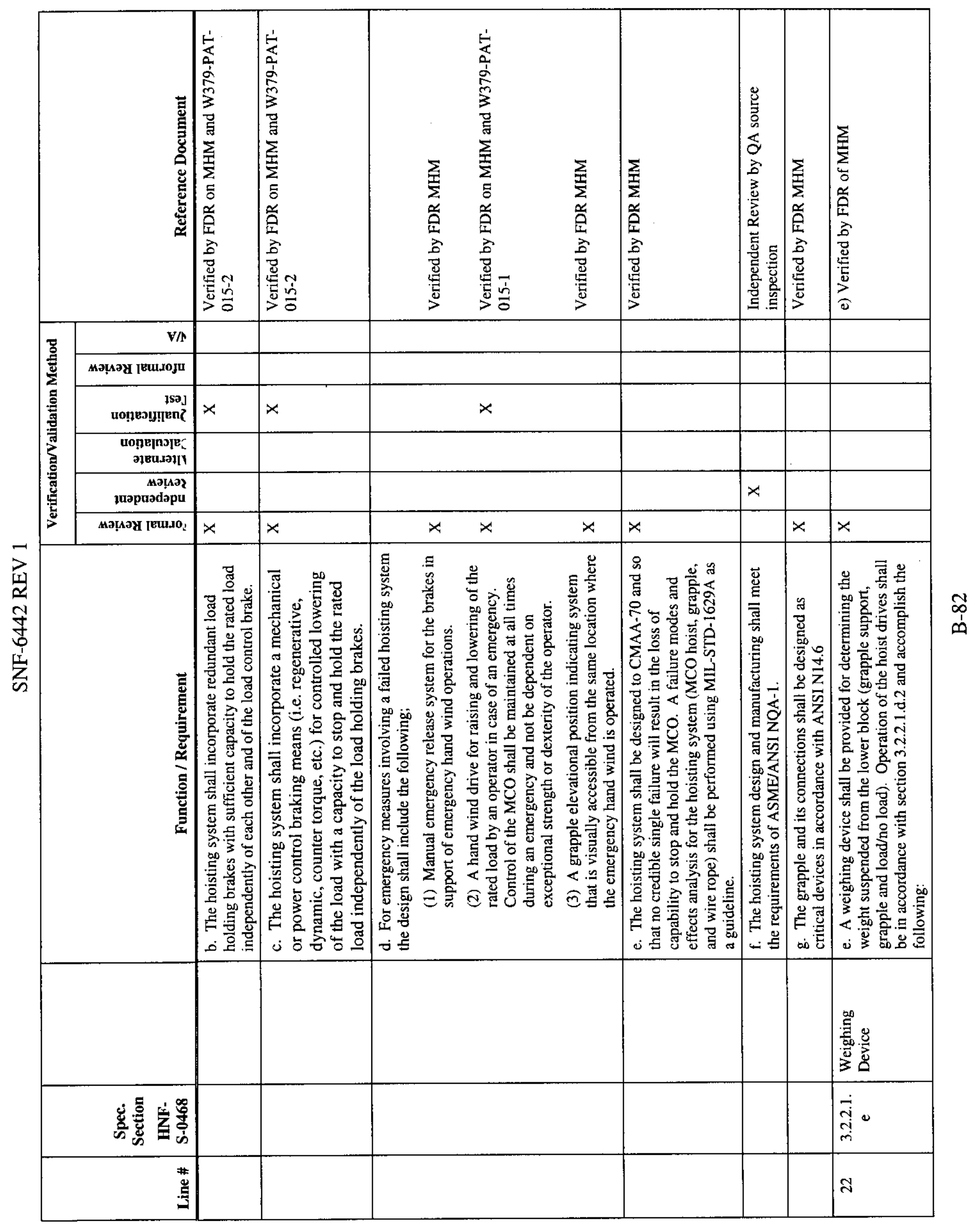




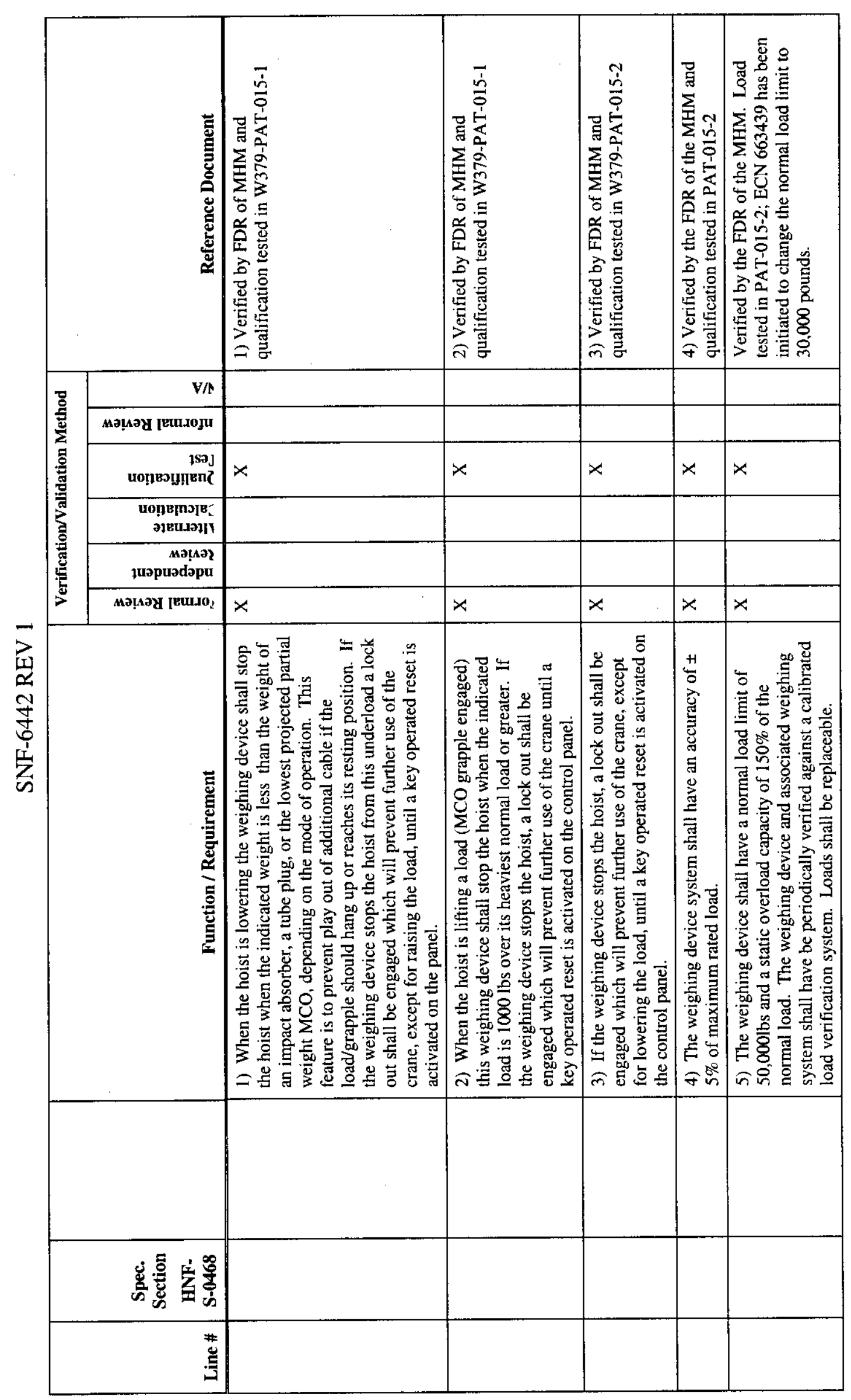




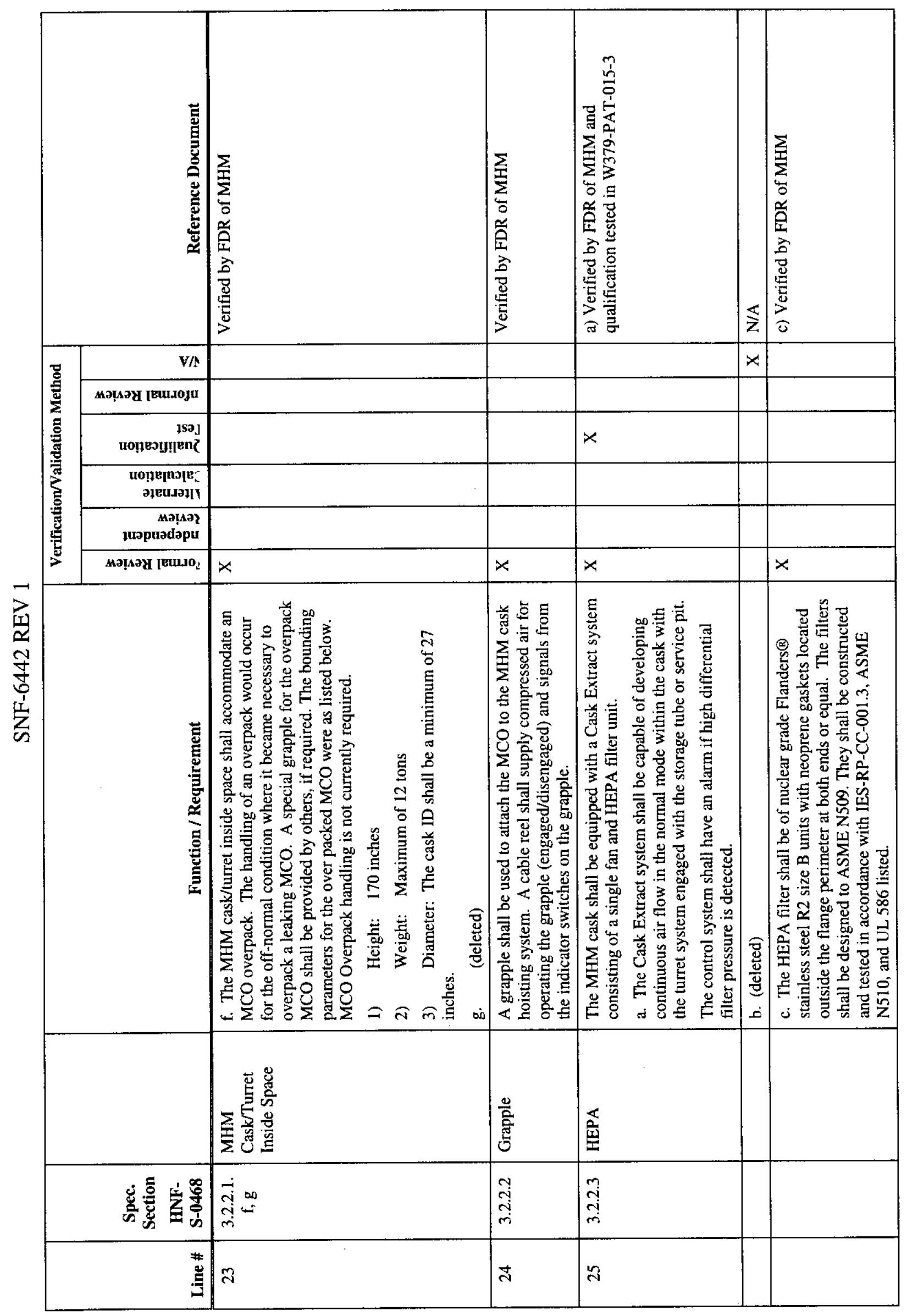




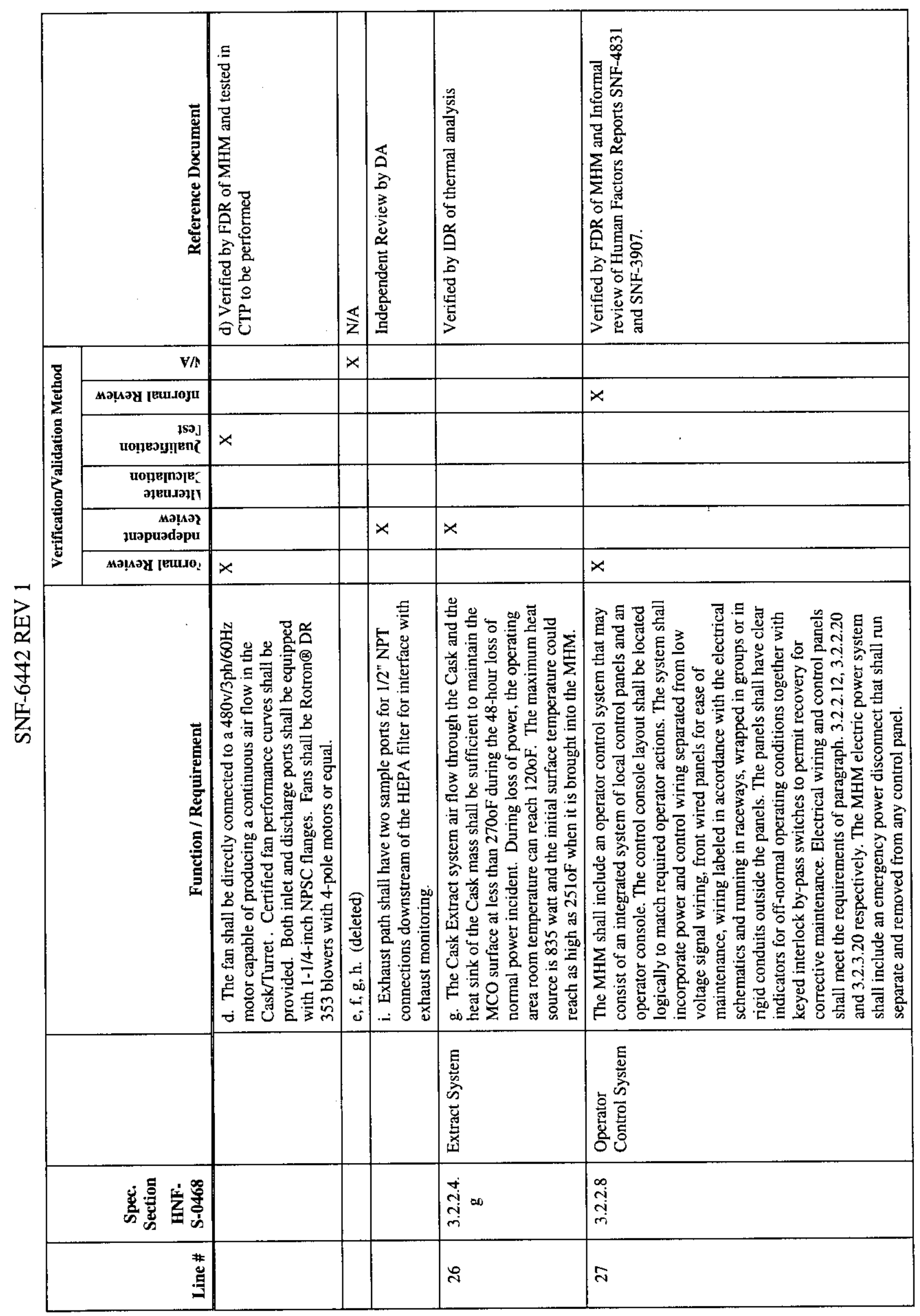




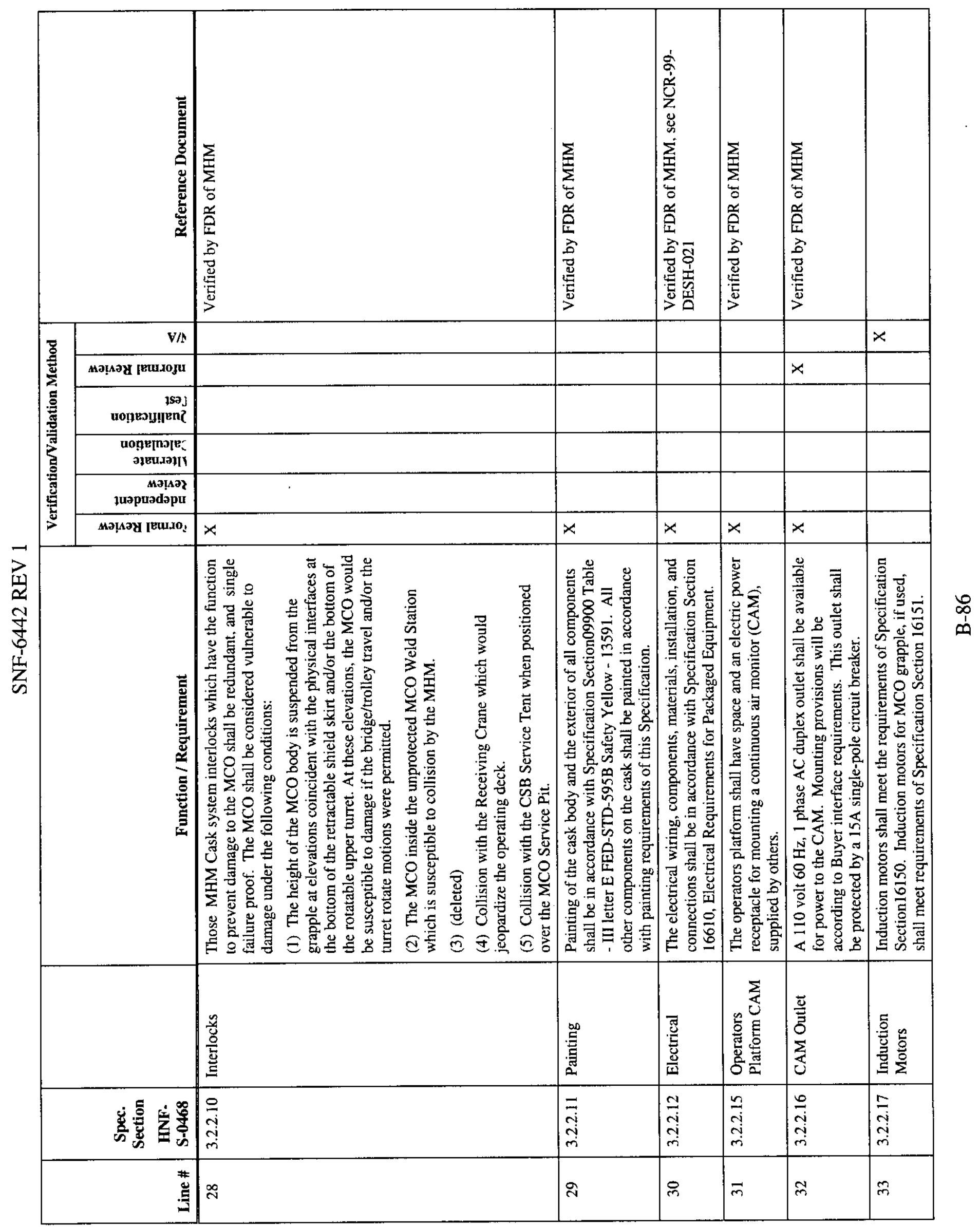




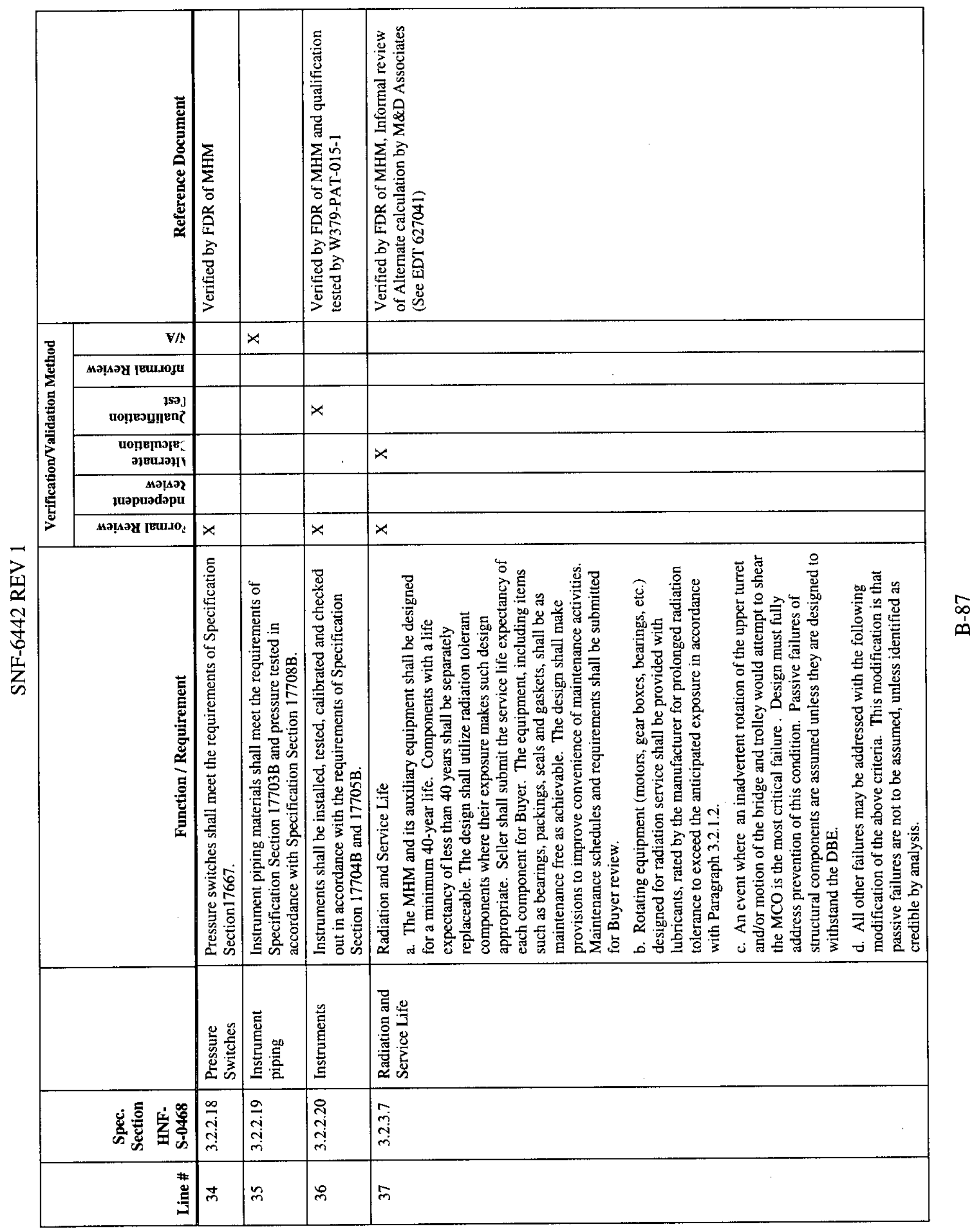




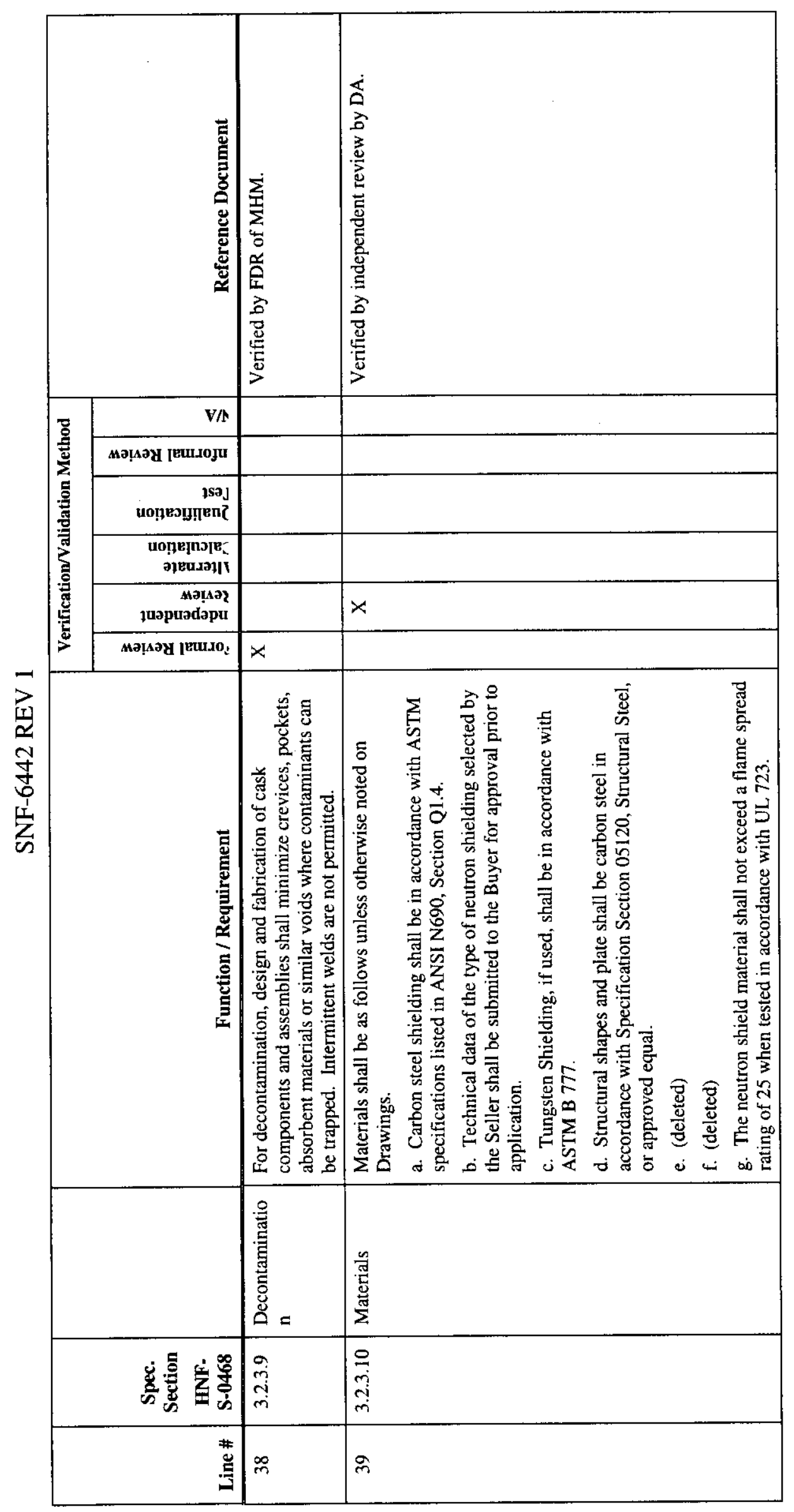

$\infty$
1
$\infty$ 


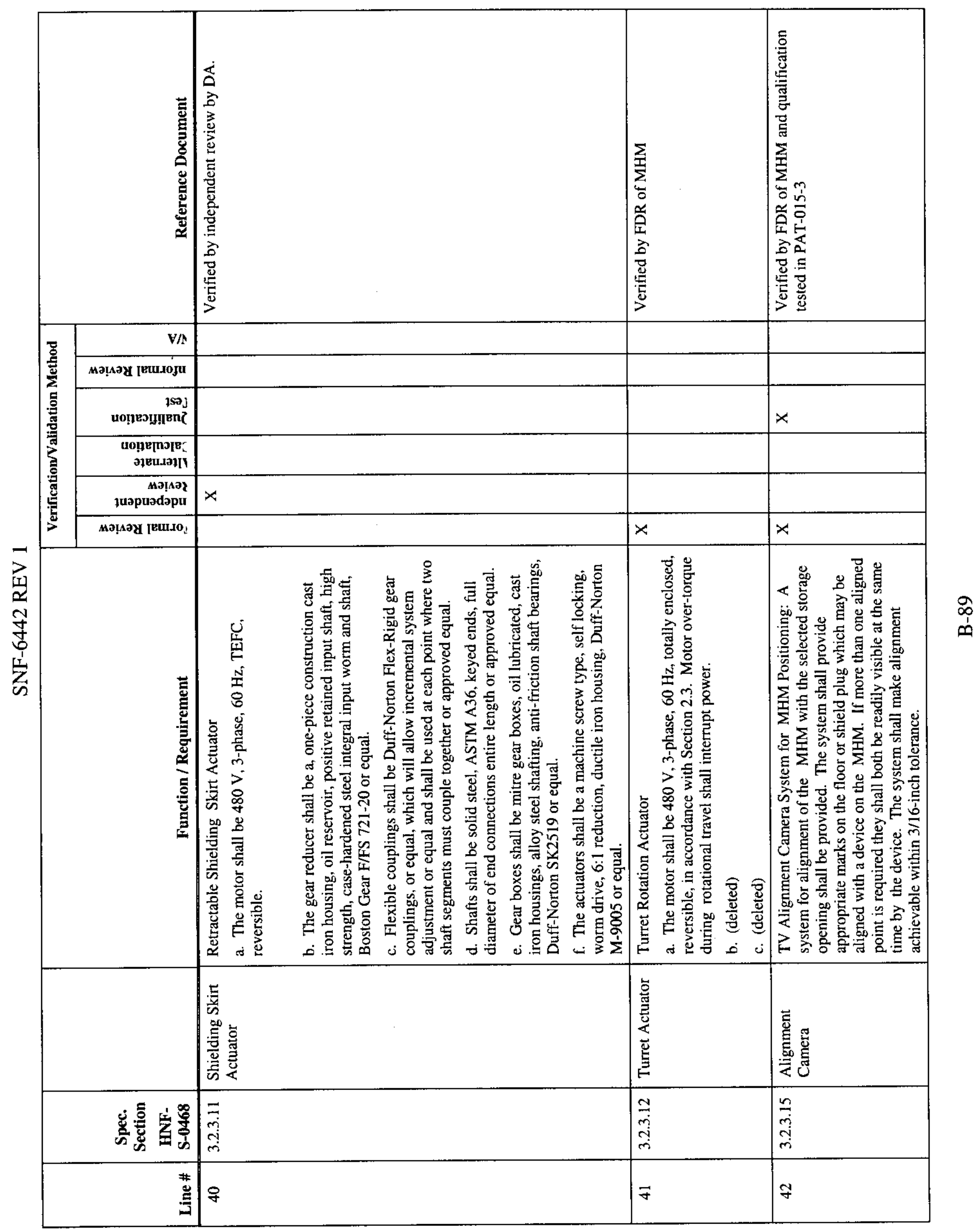




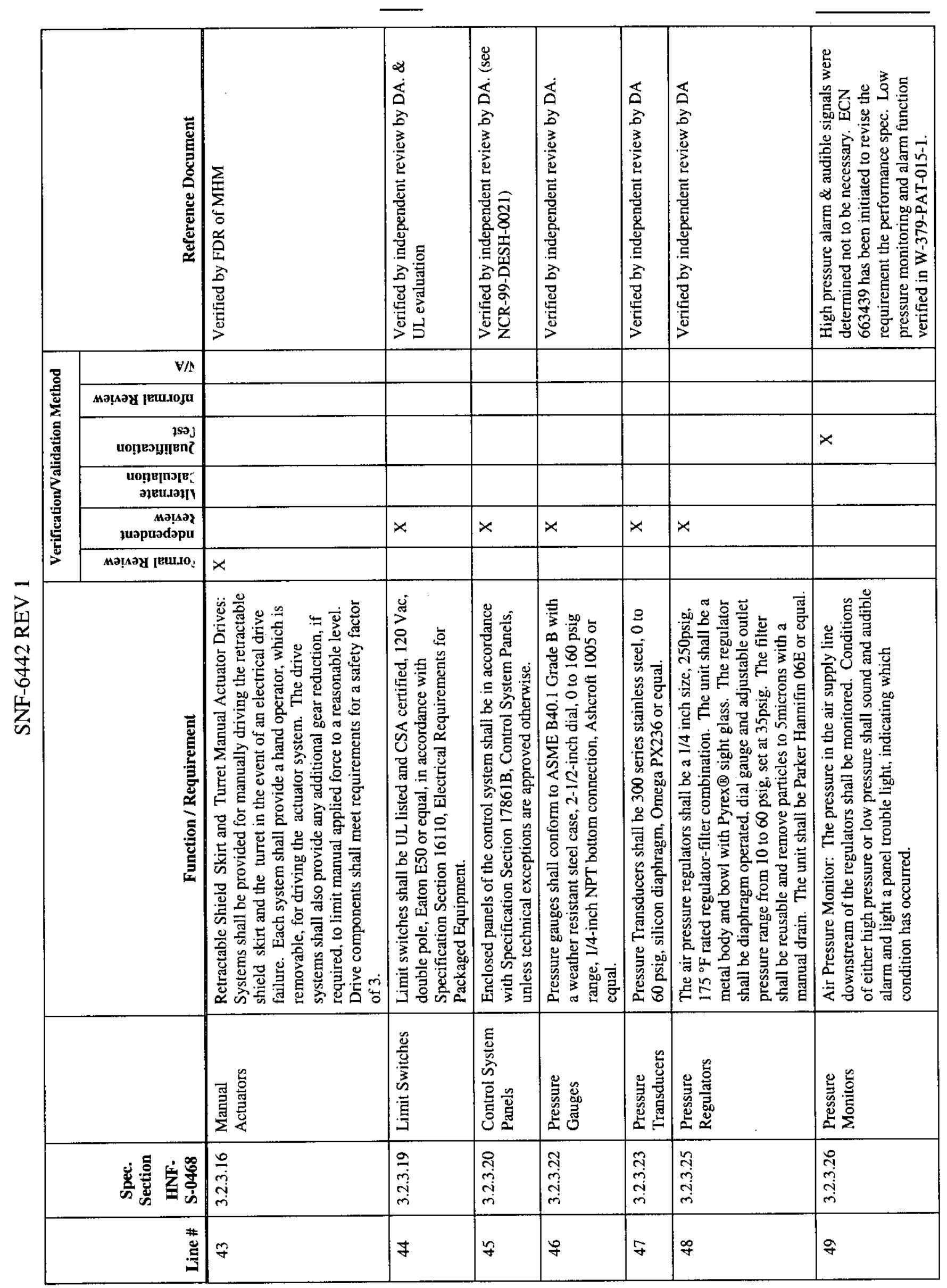

\&े
ஸे 


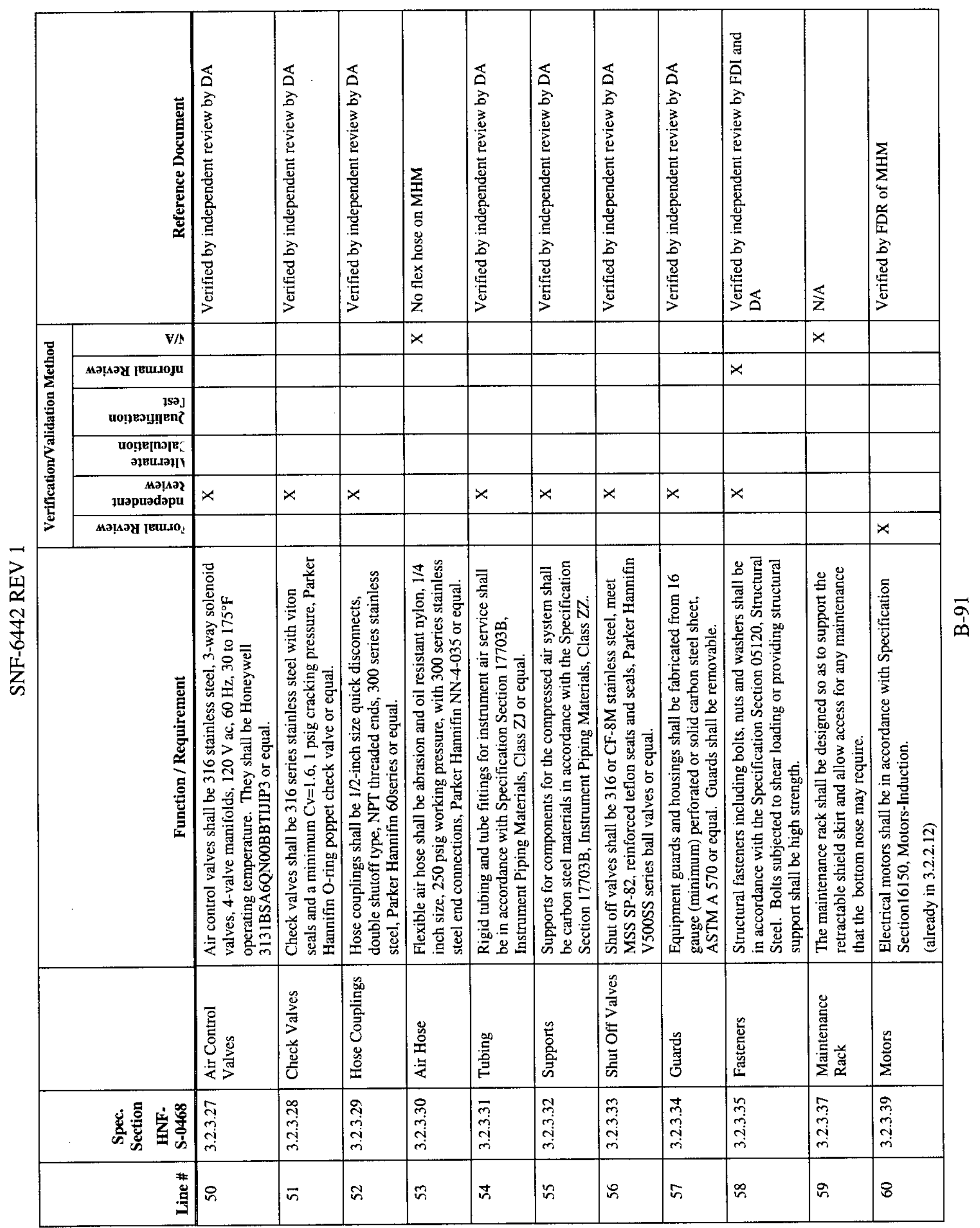




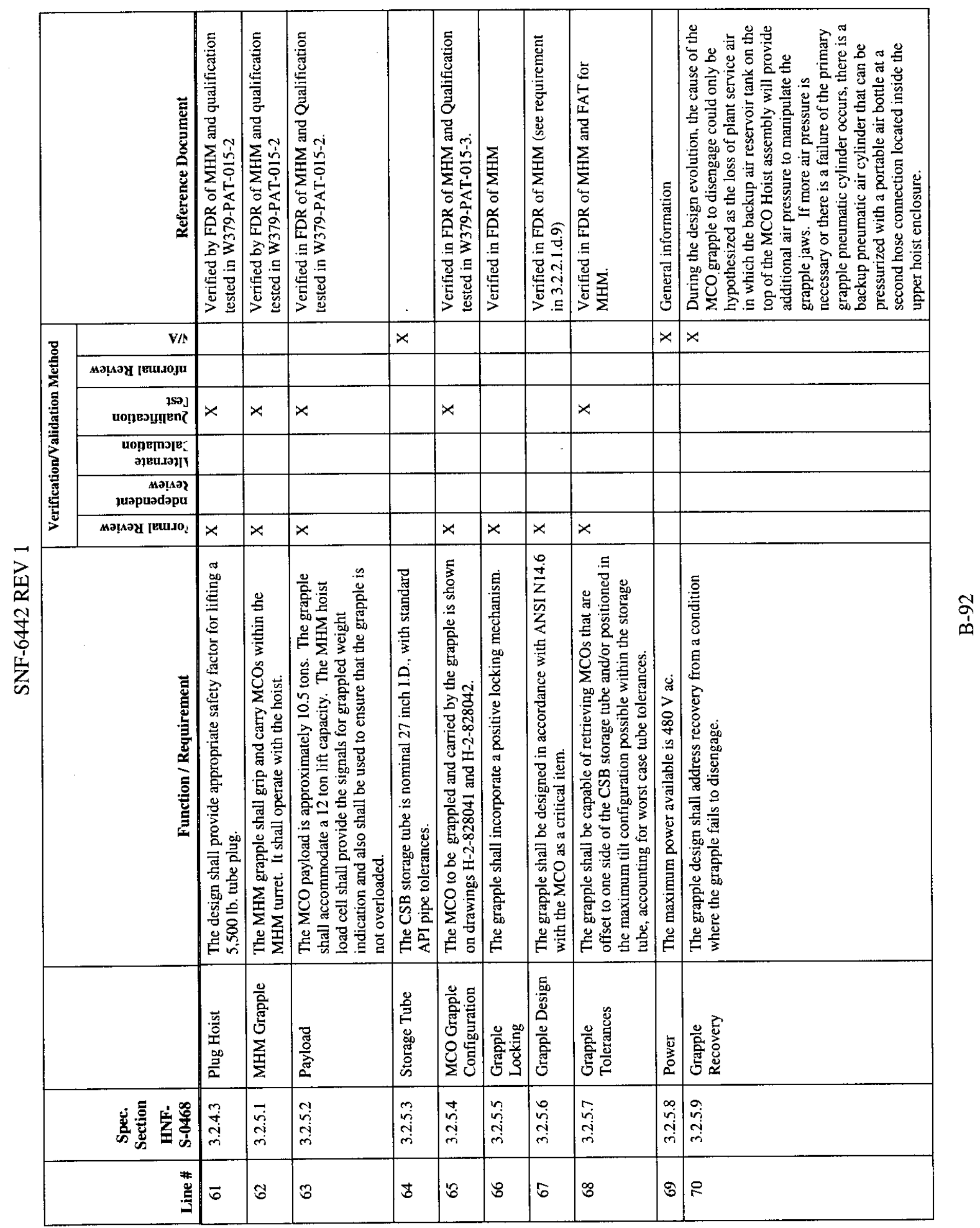




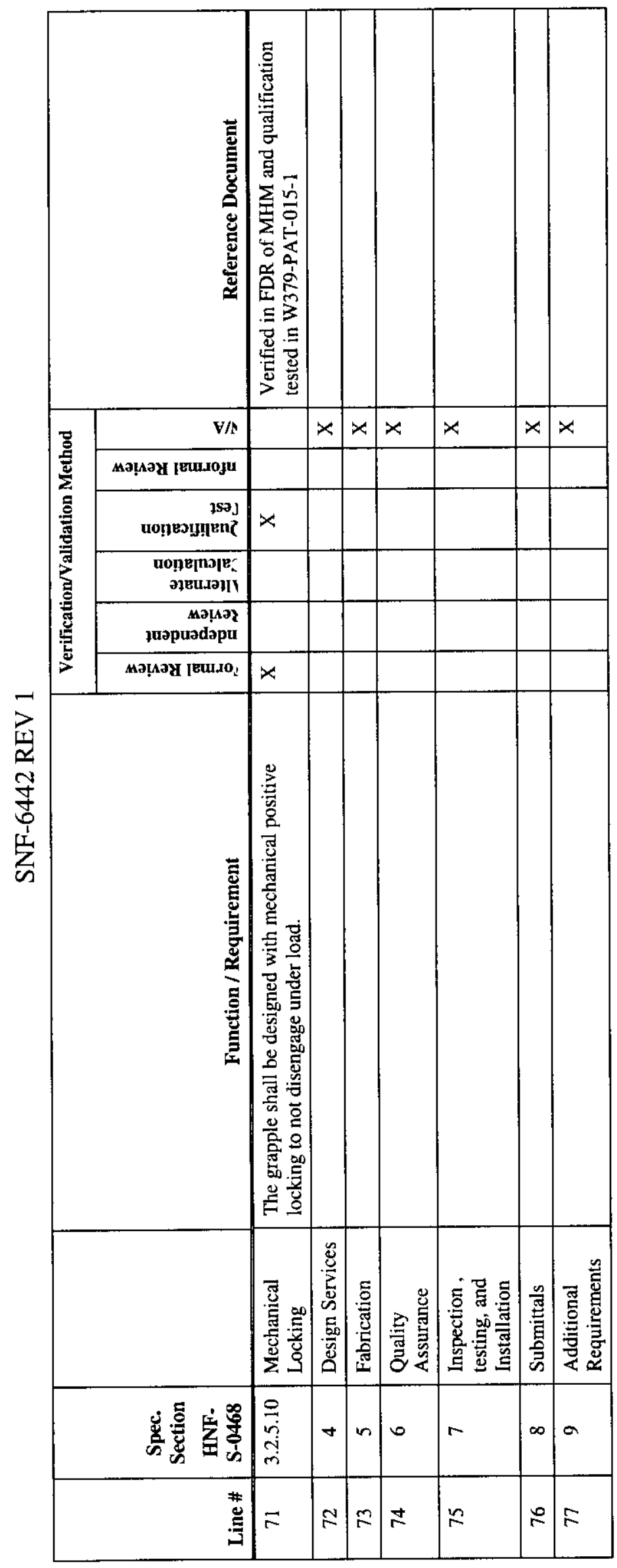

à 


\section{SNF-6442 REV 1}

This page intentionally left blank. 
SNF-6442 REV 1

APPENDIX C

DESIGN VERIFICATION STATUS QUESTIONNAIRE

C-1 


\section{SNF-6442 REV 1}

This page intentionally left blank. 


\section{SNF-6442 REV 1}

(1a) SNF 8UBPROJECT:

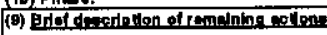

(2) Acesesemont Deto:

(j) 8elf-Amemament properod by:

(10) Independent Acormement done by:

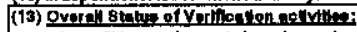

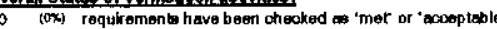

(8) (100\%) requiremenks neede oomplementary acions

o (0x) requiremente are not met or not

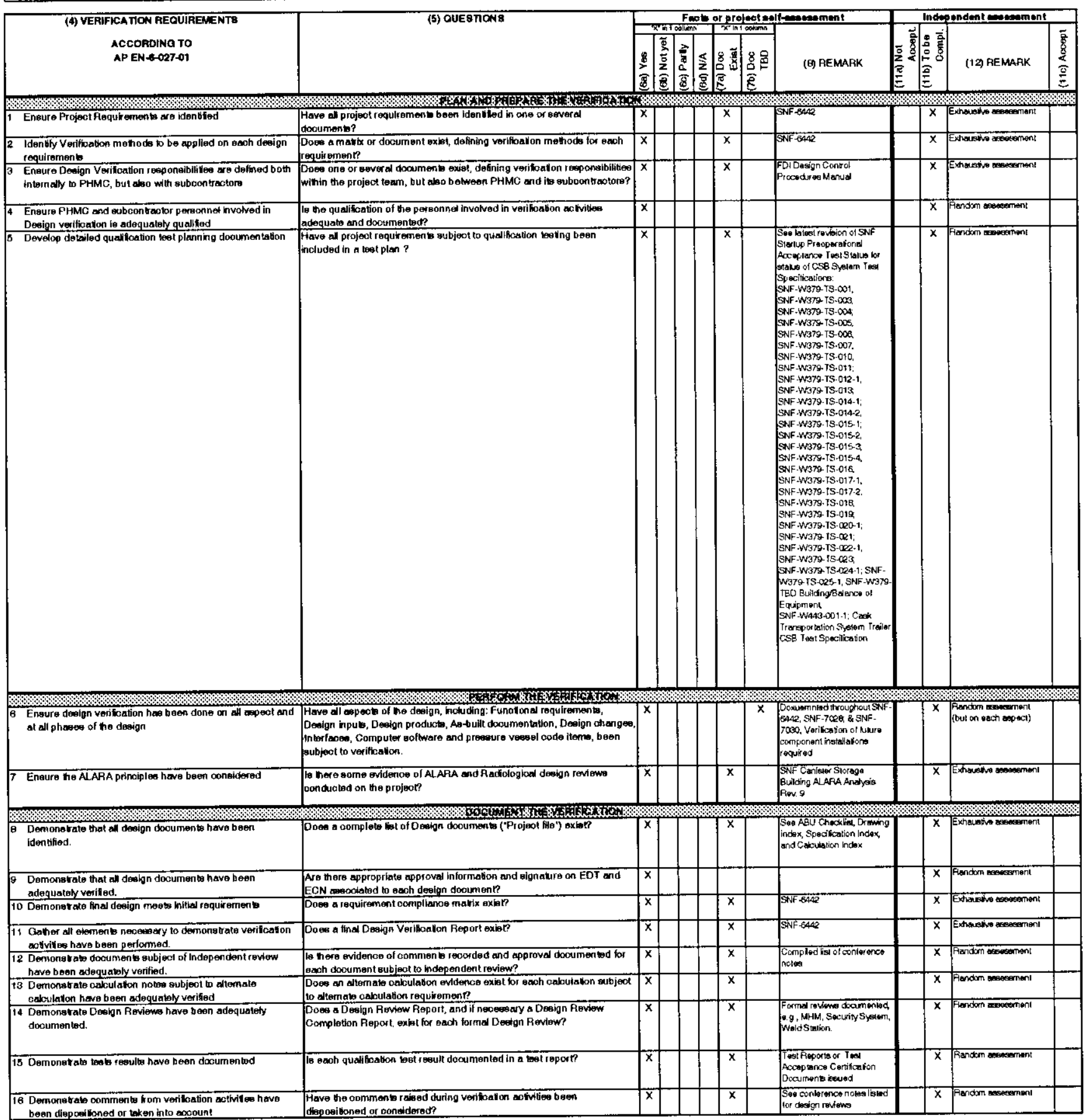


SNF-6442 REV 1

This page intentionally left blank.

C-4 